НОВАЯ НАУКА

Международный центр

научного партнерства
NEW SCIENCE

International Center for Scientific Partnership

\title{
ТРАДИЦИИ И ИННОВАЦИИ В СОВРЕМЕННОЙ НАУКЕ И ОБРАЗОВАНИИ: ТЕОРИЯ И ПЕРЕДОВАЯ ПРАКТИКА
}

Монография

г. Петрозаводск

Российская Федерация

МЦНП «Новая наука»

2021 
УДК 001.12

ББК 70

T65

Рекомендовано к публикащии редакиионной коллегией МЦНП «Новая наука»

Рецензенты:

Ершова Людмила Викторовна

доктор педагогических наук, профессор

Андрианова Людмила Прокопьевна

доктор технических наук, профессор

\section{Коллектив авторов}

Барчо О.Ф., Бура Л.В., Бурдинская А.Н., Виноградов В.Л., Газиева Л.Р., Дулов М.И., Жигайлова Л.В., Заварзина Г.А., Залевская Я.Г., Зарецкий А.М., Идигова Л.М.,

Каспаров И.В., Лосева А.С., Неделько А.А., Никитина А.А., Пегова Х.Р., Попель А.А.,

Попова В.Б., Прокопьев В.Н., Пшениснов Н.В., Свистун Г.М., Суровцева Е.В., Талышева И.А., Тихонова И.В., Фецкович И.В., Хаджиева М.М., Чуешкова А.А., Чурюканова Е.О.

ТРАДИЦИИ И ИННОВАЦИИ В СОВРЕМЕННОЙ НАУКЕ И ОБРАЗОВАНИИ: ТЕОРИЯ И ПЕРЕДОВАЯ ПРАКТИКА : [моНОГрафИЯ / Барчо О. Ф. и др.] ; Петрозаводск : МЦНП «Новая наука», 2021. — 286 с. : ил. Коллектив авторов.

ISBN 978-5-00174-150-3

В монографии рассматривается круг актуальных вопросов, стоящих перед современными исследователями, обозначается комплекс научной проблематики охватываемых сфер, предлагается новое видение ряда концептов. Издание может быть полезно научным работникам, специалистам-практикам, преподавателям всех уровней образования, интересующимся проблемами развития современной науки и образования.

Авторы публикуемых материалов несут ответственность за содержание своих работ, точность цитат, легитимность использования иллюстраций, приведенных цифр, фактов, названий, персональных данных и иной информации, а также за соблюдение законодательства Российской Федерации и сам факт публикации.

Полные тексты статей в открытом доступе размещены в Научной электронной библиотеке Elibrary.ru в соответствии с Договором № 467-03/2018K от 19.03.2018 г.

УДК 001.12

ББК 70

ISBN 978-5-00174-150-3

(C) Коллектив авторов, текст, иллюстрации, 2021

() МЦНП «Новая наука» (ИП Ивановская И.И.), оформление, 2021 


\section{ОГЛАВЛЕНИЕ}

ГЛАВА І. СОВРЕМЕННОЕ ОБРАЗОВАНИЕ: ПРОБЛЕМЫ, РЕШЕНИЯ И ИННОВАЦИИ.

РЕЗУЛЬТАТЫ ОБРАЗОВАНИЯ И ФЕДЕРАЛЬНЫЕ ОБРАЗОВАТЕЛЬНЫЕ

СТАНДАРТЫ В КОНТЕКСТЕ ФОРМИРОВАНИЯ

ФУНКЦИОНАЛЬНОЙ ГРАМОТНОСТИ.

Виноградов Владисла Львович, Тальщева Ирина Анатольевна,

Пегова Хэнэ Раилевна

ОРГАНИЗАЦИЯ ДЕЯТЕЛЬНОСТИ ПСИХОЛОГИЧЕСКОЙ СЛУЖБЫ ВУЗА

В УСЛОВИЯХ ДИСТАНЦИОНОГО ОБУЧЕНИЯ

Бура Людмила Викторовна, Залевская Яна Геннадиевна

ОНЛАЙН-ТЕХНОЛОГИИ В ОБУЧЕНИИ ИНОСТРАННЫМ ЯЗЫКАМ:

ВЗГЛЯД ИЗНУТРИ

Каспаров Игорь Викторович, Попель Александр Александрович,

Пшениснов Николай Владимирович

ИГРОВЫЕ ТЕХНОЛОГИИ И ИХ МЕСТО В ОБУЧЕНИИ

ИНОСТРАННОМУ ЯЗЫКУ 46

Чурюканова Елена Олеговна

К ВОПРОСУ О ВИЗУАЛЬНОЙ ФОРМЕ ОБУЧАЮЩИХ МАТЕРИАЛОВ ДЛЯ СТУДЕНТОВ СПЕЦИАЛЬНОСТИ ЮРИСПРУДЕНЦИЯ НАЧАЛЬНЫХ КУРСОВ.

Зареичий Андрей Михайлович

ЭКОЛОГИЧЕСКОЕ ВОСПИТАНИЕ ШКОЛЬНИКОВ НА УРОКАХ

ГЕОГРАФИИ И ВО ВНЕКЛАССНОЙ РАБОТЕ ПО ПРЕДМЕТУ

Чуешкова Алла Анатольевна

ОСНОВНЫЕ ТРЕБОВАНИЯ К ДВИГАТЕЛЬНОЙ ПОДГОТОВКЕ

ДЕТЕЙ 6-7 ЛЕТ

Жигайлова Лариса Валентиновна, Свистун Галина Михайловна,

Тихонова Ирина Владимировна, Барчо Ольга Федоровна

ФОРМИРОВАНИЕ САМООЦЕНКИ МЛАДШИХ ШКОЛЬНИКОВ

В УЧЕБНО-ВОСПИТАТЕЛЬНОМ ПРОЦЕССЕ 106

Неделько Анна Александровна

\section{ГЛАВА ІІ. ФУНКЦИОНАЛЬНЫЕ АСПЕКТЫ ЯЗЫКА:}

ПРОШЛОЕ И НАСТОЯЩЕЕ.

ПОЛИТИЧЕСКИЙ ЯЗЫК СОВРЕМЕННОЙ ЭПОХИ: К ПРОБЛЕМЕ

ОПИСАНИЯ ИННОВАЦИЙ.

Заварзина Галина Анатольевна

ИЗ ИСТОРИИ ЭПИСТОЛЯРНЫХ ОБРАЩЕНИЙ М.В.ЛОМОНОСОВА

В ВЫШЕСТОЯЩИЕ ИНСТАНЦИИ

Суровцева Екатерина Владимировна 


\section{ГЛАВА ІІІ. НЕКОТОРЫЕ ВОПРОСЫ ОБЕСПЕЧЕНИЯ}

БЕЗОПАСНОСТИ.

ПОСТАВЛЕНИЕ В ОПАСНОСТЬ ЗАРАЖЕНИЯ ЛИБО ЗАРАЖЕНИЕ ВИЧ-ИНФЕКЦИЕЙ (СТ. 122 УК РФ): ОСНОВНЫЕ ПРИЧИНЫ И УСЛОВИЯ; ЛИЧНОСТЬ ВИЧ-ИНФИЦИРОВАННОГО ПРЕСТУПНИКА 149

Бурдинская Анна Николаевна

НЕКОТОРЫЕ РЕЗУЛЬТАТЫ РЕАЛИЗАЦИИ НАЦИОНАЛЬНОГО ПРОЕКТА «БЕЗОПАСНЫЕ И КАЧЕСТВЕННЫЕ АВТОМОБИЛЬНЫЕ ДОРОГИ» В ЧЕЧЕНСКОЙ РЕСПУБЛИКЕ ЗА 2019-2020 ГОДЫ 171 Идигова Лалита Мусаевна, Газиева Лейла Руслановна, Хаджсиева Марьям Маулдыновна

ОБЕСПЕЧЕНИЕ БЕЗОПАСНОСТИ ТУРИСТИЧЕСКОЙ СФЕРЫ И ЕЁ ЭФФЕКТИВНОСТЬ (КРАТКИЙ ОБЗОР ЛИТЕРАТУРЫ) 184 Прокопьев Виктор Николаевич

ГЛАВА ІV. СОСТОЯНИЕ И ПЕРСПЕКТИВЫ РАЗВИТИЯ СОВРЕМЕННОГО СЕЛЬСКОГО ХОЗЯЙСТВА...........................................2235

УБОРКА УРОЖАЯ, ХРАНЕНИЕ И ПЕРЕРАБОТКА ПЛОДОВ ЯБЛОНИ..... 235 Дулов Михаил Иванович

СТРУКТУРНЫЕ И ДИНАМИЧЕСКИЕ ОСОБЕННОСТИ АГРАРНОГО ПРОИЗВОДСТВА ТАМБОВСКОЙ ОБЛАСТИ 253 Попова Вера Борисовна, Лосева Алла Сергеевна, Фецкович Игорь Владимирович ПОВЫШЕНИЕ ЭФФЕКТИВНОСТИ РЕСУРСНОГО ПОТЕНЦИАЛА КРЕСТЬЯНСКИХ (ФЕРМЕРСКИХ) ХОЗЯЙСТВ РЕСПУБЛИКИ БАШКОРТОСТАН 269

Никитина Анжелика Александровна 


\title{
ГЛАВА І. \\ СОВРЕМЕННОЕ ОБРАЗОВАНИЕ: ПРОБЛЕМЫ, РЕШЕНИЯ И ИННОВАЦИИ
}

УДК 371.3

\author{
РЕЗУЛЬТАТЫ ОБРАЗОВАНИЯ И ФЕДЕРАЛЬНЫЕ \\ ОБРАЗОВАТЕЛЬНЫЕ СТАНДАРТЫ В КОНТЕКСТЕ ФОРМИРОВАНИЯ \\ ФУНКЦИОНАЛЬНОЙ ГРАМОТНОСТИ
}

Виноградов Владисла Львович
к.П.н., доцент
Талышева Ирина Анатольевна
к.П.н., доцент
Пегова Хэнэ Раилевна
старший преподаватель
Елабужский институт (филиал) ФГАОУ ВО КФУ

Аннотация: Говоря о результатах образования, которые должна обеспечить современная школа в первую очередь, всё чаще начинают использовать некоторые интегральные понятия, обозначающие целый комплекс взаимосвязанных компетенций: «гибкие навыки», «мягкие компетенции», «универсальные компетенции» и т.п. К таким понятиям относится и «функциональная грамотность». В данной работе авторами была проделана работа по сопоставлению элементов функциональной грамотности с результатами образования, представленными в ФГОС ОО.

Ключевые слова: функциональная грамотность, результаты образования, личностные результаты образования, предметные результаты образования, метапредметные результаты образования.

\section{EDUCATIONAL RESULTS AND FEDERAL EDUCATIONAL STANDARDS IN THE CONTEXT OF FORMING FUNCTIONAL LITERACY}




\title{
Vinogradov Vladislav Lvovich \\ Talysheva Irina Anatolevna \\ Pegova Khene Railevna
}

\begin{abstract}
Speaking about the results of education, which should provide a modern school in the first place, they are increasingly beginning to use some integral concepts denoting a whole range of interrelated competencies: "flexible skills", "soft competences", "universal competences", etc. These concepts include "functional literacy". In this work, the authors have done work on comparing the elements of functional literacy with the results of education presented in the federal educational standard.
\end{abstract}

Key words: functional literacy, educational outcomes, personal educational outcomes, subject educational outcomes, meta-subject educational outcomes.

\section{1. ФУНКЦИОНАЛЬНАЯ ГРАМОТНОСТЬ И ЛИЧНОСТНЫЕ РЕЗУЛЬТАТЫ ОБРАЗОВАНИЯ}

Образование - социальный институт, функционирующий по утвержденным правилам, на основе сложившихся вековых традиций и с учетом установленных требований к образовательным результатам. И требования эти задаются в России Федеральными государственными образовательными стандартами [7].

Именно очерченные в ФГОС результаты и должны прежде всего отражаться в основной образовательной программе образовательной организации, в тематическом и урочном планировании. И если этого не будет сделано, то работа школы будет признана неудовлетворительной. А если результаты образования по ФГОС в полной мере отражены в ООП и будут реализованы в образовательном процессе, то сверх этого мы можем достигать чего угодно, в том числе, формировать функциональную грамотность. Такова логика работы социального института.

Для начала нам нужно понять, что функциональная грамотность и результаты образования по ФГОС не исключают, а дополняют друг друга. Возьмем, например, центральную составляющую функциональной грамотности. Школа и без этого обучает чтению, математике и естественным наукам. Но обучать и обеспечивать понимание и способность практического 
использования - не одно и то же. Выходит, функциональная грамотность, имеет отношение не к наименованию грамотности (компетенций), а к их содержанию - знать и применять. В этом и заключается системно-деятельностный подход к образованию. Вот эти пересечения функциональной грамотности и федерального государственного образовательного стандарта необходимо учитывать при реализации образовательного процесса. Но прежде, еще несколько слов о важном.

Нами была предпринята попытка уточнения структуры функциональной грамотности, за основу нашей работы был взят текст проекта ФГОС основного общего образования [5] по его состоянию на декабрь 2020 года, предполагая, что именно он будет определять работу школы в ближайшем будущем.

Сопоставление компонентов функциональной грамотности и результатов образования, начнем с личностных результатов, включающих: «осознание российской гражданской идентичности; готовность обучающихся к саморазвитию, самостоятельности и личностному самоопределению; ценность самостоятельности и инициативы; наличие мотивации к целенаправленной социально-значимой деятельности; сформированность внутренней позиции личности как особого ценностного отношения к себе, к окружающим людям и к жизни в целом».

Личностные результаты образования в тексте стандарта детализируются: выделяется несколько групп результатов, достигаемых в рамках соответствующих направлений воспитания: патриотического, гражданского, духовно-нравственного, эстетического, воспитания ценности научного познания, физического, трудового и экологического воспитания [2; 3].

Возьмем, для примера, результаты гражданского воспитания, предполагающие:

ЛГ-1: готовность к выполнению обязанностей гражданина и реализации его прав, уважение прав, свобод и законных интересов других людей;

ЛГ-2: активное участие в жизни семьи, образовательной организации, местного сообщества, родного края, страны;

ЛГ-3: неприятие любых форм экстремизма, дискриминации;

ЛГ-4: понимание роли различных социальных институтов в жизни человека; 
ЛГ-5: представление об основных правах, свободах и обязанностях гражданина, социальных нормах и правилах межличностных отношений в поликультурном и многоконфессиональном обществе;

ЛГ-6: готовность к разнообразной совместной деятельности, стремление к взаимопониманию и взаимопомощи, активное участие в школьном самоуправлении;

ЛГ-7: готовность к участию в гуманитарной деятельности (волонтерство; помощь людям, нуждающимся в ней).

Каждому результату мы присвоили индекс (маркер), позволяющий его идентифицировать. В самом стандарте такая маркировка отсутствует, но нам она в дальнейшем очень пригодится. Расшифровывается маркер очень просто. Например, «ЛГ-1» означает Личностный Гражданское №1 по порядку.

Попробуем распределить обозначенные результаты в соответствии с видами функциональной грамотности (табл. 1).

\section{Таблица 1}

\section{Соотнесение личностных результатов освоения ООП видам} функциональной грамотности

\begin{tabular}{|l|l|}
\hline \multicolumn{1}{|c|}{ ГРАМОТНОСТь } & \multicolumn{1}{|c|}{ Личностные результаты освоения ООП } \\
\hline Глобальные компетенции & $\begin{array}{l}\text { ЛГ-2 активное участие в жизни образовательной } \\
\text { организации, местного сообщества, родного края, страны }\end{array}$ \\
\hline Юридическая & $\begin{array}{l}\text { ЛГ-5 представление об основных правах, свободах и } \\
\text { обязанностях гражданина, социальных нормах и правилах } \\
\text { межличностных отношений в поликультурном и } \\
\text { многоконфессиональном обществе }\end{array}$ \\
\hline Семейная & ЛГ-2 активное участие в жизни семьи \\
\hline Коммуникативная & $\begin{array}{l}\text { ЛГ-6 готовность к разнообразной совместной } \\
\text { деятельности, стремление к взаимопониманию и } \\
\text { взаимопомощи, активное участие в школьном } \\
\text { самоуправлении }\end{array}$ \\
\hline Диалогическая & $\begin{array}{l}\text { ЛГ-4 понимание роли различных социальных институтов в } \\
\text { жизни человека }\end{array}$ \\
\hline Критическая & ЛГ-3 неприятие любых форм экстремизма, дискриминации \\
\hline Интерактивная & $\begin{array}{l}\text { ЛГ-1 готовность к выполнению обязанностей гражданина } \\
\text { и реализации его прав, уважение прав, свобод и законных } \\
\text { интересов других людей }\end{array}$ \\
\hline Общественно-политическая & $\begin{array}{l}\text { ЛГ-7 готовность к участию в гуманитарной деятельности } \\
\text { (волонтерство; помощь людям, нуждающимся в ней) }\end{array}$ \\
\hline
\end{tabular}




\section{ТРАДИЦИИ И ИННОВАЦИИ В СОВРЕМЕННОЙ НАУКЕ И ОБРАЗОВАНИИ: ТЕОРИЯ И ПЕРЕДОВАЯ ПРАКТИКА}

Все личностные результаты в части гражданского воспитания у нас распределились в таблице в соответствии с видами функциональной грамотности.

\section{2. ФУНКЦИОНАЛЬНАЯ ГРАМОТНОСТЬ И МЕТАПРЕДМЕТНЫЕ РЕЗУЛЬТАТЫ ОБРАЗОВАНИЯ}

Несмотря на то, что уже более 10 лет говорят о метапредметности образования, понятие «метапредметность» всё еще вызывает затруднения. Для понимания термина «метапредметность», приведем пример.

Спросите любого, закончившего школу, как вычислить квадрат суммы? И практически все, независимо от возраста и рода их деятельности, сразу ответят, что квадрат суммы равен сумме квадрата первого слагаемого, удвоенного произведения первого и второго слагаемого и квадрата второго слагаемого. Вопрос «Для чего Вы это помните?» у всех вызовет затруднение, переходящее в недоумение. Ответы типа «Для общего развития» или «Ненужных знаний не бывает» удовлетворения не дают. Все понимают, что в эпоху интернета ненужные знания есть... Никто кроме математиков или учителей математики ни разу в жизни на практике это знание не применял (к вопросу о функциональной грамотности). Для чего же тогда мы это учим, да еще так, что на всю жизнь?

Ответ достаточно прост. Освоение математики формирует логическое мышление и память, способность выстраивать способы достижения результата, усидчивость, сосредоточенность и множество иных качеств, крайне необходимых для эффективного существования и используемых в повседневной жизни[6]. Именно эти качества и являются метапредметными формируемыми с помощью предметных знаний.

Важны не только и не столько предметные знания, сколько метапредметные компетенции «взращиваемые» на их основе [4]. Поэтому функциональная грамотность имеет прямое отношение к метапредметным результатам образования, включающим:

- «освоенные обучающимися межпредметные понятия (используются в нескольких предметных областях и позволяют связывать знания из различных дисциплин в целостную научную картину мира) и универсальные учебные действия (познавательные, коммуникативные, регулятивные);

- способность их использовать в учебной, познавательной и социальной практике; 
- готовность к самостоятельному планированию и осуществлению учебной деятельности и организации учебного сотрудничества с педагогами и сверстниками, к участию в построении индивидуальной образовательной траектории;

- овладение навыками работы с информацией: восприятие и создание информационных текстов в различных форматах, в том числе в цифровой среде, с учетом назначения информации и ее целевой аудитории».

Метапредметные результаты освоения ООП, также, как и личностные, включают в себя несколько групп:

1) овладение познавательными универсальными учебными действиями;

2) овладение регулятивными универсальными учебными действиями;

3) овладение коммуникативными универсальными учебными действиями;

4) овладение навыками участия в совместной деятельности;

5) овладение навыками работы с информацией.

Для примера возьмем «овладение коммуникативными УУД»:

M3: овладение коммуникативными универсальными учебными действиями:

M3-1: владеть смысловым чтением текстов разного вида, жанра, стиля с целью решения различных учебных задач, для удовлетворения познавательных запросов и интересов - определять тему, главную идею текста, цель его создания;

M3-2: устранять в рамках общения разрывы в коммуникации, обусловленные непониманием / неприятием со стороны собеседника учебной задачи, формы или содержания диалога;

M3-3: выявлять детали, важные для раскрытия основной темы, содержания текста, выступления, диалога;

M3-4: определять жанр выступления и в соответствии с ним отбирать содержание коммуникации, учитывать особенности аудитории;

M3-5: определять содержание выступления в соответствии с его жанром и особенностями аудитории;

М3-6: соблюдать нормы публичной речи и регламент;

M3-7: адекватно теме и ситуации общения использовать средства речевой выразительности для выделения смысловых и эмоциональных характеристик своего выступления;

M3-8: публично представлять полученные результаты практической экспериментальной или теоретической исследовательской деятельности. 
Здесь маркировка компетенций несколько иная. Так, например, «М3-1» означает метапредметный, третья группа - первый по порядку (табл.2).

Таблица 2

\section{Соотнесение метапредметных результатов освоения ООП} видам функциональной грамотности

\begin{tabular}{|c|c|}
\hline ГРАМОТНОСТЬ & Метапредметные результаты освоения ООП \\
\hline Читательская & $\begin{array}{l}\text { М3-1: владеть смысловым чтением текстов разного вида, } \\
\text { жанра, стиля с целью решения различных учебных задач, для } \\
\text { удовлетворения познавательных запросов и интересов - } \\
\text { определять тему, главную идею текста, цель его создания } \\
\text { М3-3: выявлять детали, важные для раскрытия основной темы, } \\
\text { содержания текста, выступления, диалога }\end{array}$ \\
\hline Естественно-научная & $\begin{array}{l}\text { М3-8: публично представлять полученные результаты } \\
\text { практической экспериментальной или теоретической } \\
\text { исследовательской деятельности }\end{array}$ \\
\hline Юридическая & М3-6: соблюдать нормы публичной речи и регламент \\
\hline Информационная & $\begin{array}{l}\text { М3-8: публично представлять полученные результаты } \\
\text { практической экспериментальной или теоретической } \\
\text { исследовательской деятельности }\end{array}$ \\
\hline Языковая & $\begin{array}{l}\text { М3-7: адекватно теме и ситуации общения использовать } \\
\text { средства речевой выразительности для выделения смысловых } \\
\text { и эмоциональных характеристик своего выступления }\end{array}$ \\
\hline Коммуникативная & $\begin{array}{l}\text { М3-4: определять жанр выступления и в соответствии с ним } \\
\text { отбирать содержание коммуникации, учитывать особенности } \\
\text { аудитории } \\
\text { М3-5: определять содержание выступления в соответствии с } \\
\text { его жанром и особенностями аудитории }\end{array}$ \\
\hline Диалогическая & $\begin{array}{l}\text { М3-2: устранять в рамках общения разрывы в коммуникации, } \\
\text { обусловленные непониманием / неприятием со стороны } \\
\text { собеседника учебной задачи, формы или содержания диалога }\end{array}$ \\
\hline
\end{tabular}

Вот таким образом у нас получилось соотнести метапредметные результаты освоения основной образовательной программы с различными видами функциональной грамотности. 


\section{3. ФУНКЦИОНАЛЬНАЯ ГРАМОТНОСТЬ И ПРЕДМЕТНЫЕ} РЕЗУЛЬТАТЫ ОБРАЗОВАНИЯ

Стандарт устанавливает требования к предметным результатам обучающихся, освоивших основную образовательную программу основного общего образования, включающим:

- «освоенные обучающимися в ходе изучения учебного предмета научные знания, умения и способы действий, специфические для данной предметной области;

- предпосылки научного типа мышления;

- виды деятельности по получению нового знания, его интерпретации, преобразованию и применению в различных учебных ситуациях, а также при создании учебных и социальных проектов»[1].

Учитывая, что стандарт предусматривает обучение по 16 предметам, нам придется выбрать для примера один из них. Пусть это будет математика. Вопервых, мы уже о ней вспоминали, говоря о метапредметности образования, вовторых, это один из двух обязательных предметов в структуре ЕГЭ, и, втретьих, это действительно уникальный по своей значимости предмет.

М.А. Чошанов, анализируя угрожающую ситуацию с математическим образование в США на рубеже 21 века, отмечает: «... в Соединенных Штатах в 2000 г. была создана специальная комиссия по проблемам школьного образования. ... Комиссия составила доклад президенту страны под названием «Пока не поздно». В нем среди прочего говорится: «Комиссия убеждена, что на заре нового столетия и тысячелетия будущее благосостояние нашего государства зависит не только от того, насколько мы хорошо обучаем детей в целом, но и от того, насколько мы хорошо обучаем естественным, фундаментальным наукам и математике. Эти науки дают нам продукты, уровень жизни, экономическую и военную безопасность, которые будут поддерживать нас как дома, так и во всем мире» [8, с.13]. Состояние математического образования в любом современном обществе - вопрос национальной безопасности.

Сопоставление предметных математических результатов освоения ООП различным видам функциональной грамотности оказывается задачей одновременно и простой, и сложной. Прежде всего, проект ФГОС ООО, в отличие от аналогичного стандарта-предшественника, гораздо более детально описывает ожидаемые результаты по годам обучения (на 8 страницах), что 
является общей особенностью проекта в отношении всех 16-ти предметов. Кроме этого, любой результат, воспринимающийся как чисто математический, по здравому размышлению оказывается связанным с функциональной грамотностью или непосредственно, или опосредовано (через метапредметность результата).

Например, предметная 11-я компетенция, математика 5-го года обучения (П11-Мат5): «выбирать подходящий метод для решения изученных типов математических задач; используя известные методы, проводить геометрические доказательства, опровергать ложные высказывания, в том числе с помощью контрпримеров». Несмотря на абсолютно математическое звучание, явно напрашивается связь обозначенной компетенции с такими видами функциональной грамотности как читательская (смысловое чтение) и критическая (о собственно математической грамотности мы не говорим).

Об опосредованной взаимосвязи математики с другими видами функциональной грамотности можно даже и не говорить. Будучи языком науки и логического мышления, математика в неявном виде присутствует при решении теоретических и практических задач в любой сфере деятельности.

Было бы несправедливо не отметить те предметные математические результаты, которые имеют явный практико-ориентированный контекст и, соответственно, связаны с функциональной грамотностью более четко. Очевидно, к математической и естественно-научной грамотности имеют отношение все без исключения предметно-математические компетенции, прописанные в стандарте (табл.3).

\section{Таблица 3}

\section{Соотнесение предметных результатов освоения ООП}

\section{видам функциональной грамотности}

\begin{tabular}{|c|c|}
\hline ГРАМОТНОСТЬ & Предметные результаты освоения ООП \\
\hline Естественно-научная & Все компетенции \\
\hline Математическая & Все компетенции \\
\hline Финансовая & $\begin{array}{l}\text { П7-Мат2: решать сюжетные задачи на все арифметические } \\
\text { действия, интерпретировать полученные результаты; решать } \\
\text { задачи следующих типов: на проценты, отношения и } \\
\text { пропорции; на соотношения между величинами (цена, } \\
\text { количество, стоимость; скорость, время, расстояние; данные } \\
\text { бытовых приборов учёта расхода электроэнергии, воды, газа), } \\
\text { задачи из области управления личными и семейными } \\
\text { финансами; }\end{array}$ \\
\hline
\end{tabular}




\begin{tabular}{|l|l|}
\hline Информационная & $\begin{array}{l}\text { П5-Мат1: оперировать понятием: столбчатая диаграмма; } \\
\text { интерпретировать, преобразовывать и использовать при } \\
\text { решении учебных и практических задач информацию, } \\
\text { представленную в таблицах, схемах и столбчатых диаграммах }\end{array}$ \\
\hline ЧС-грамотность & $\begin{array}{l}\text { П8-Мат1: изображать изучаемые фигуры от руки и с помощью } \\
\text { чертежных инструментов; выполнять измерение длин, } \\
\text { расстояний, в том числе в практических ситуациях }\end{array}$ \\
\hline Бытовая & $\begin{array}{l}\text { Пб-Мат1: решать сюжетные задачи на все арифметические } \\
\text { действия, интерпретировать полученные результаты; решать } \\
\text { задачи следующих типов: на нахождение части числа и числа } \\
\text { по его части; на соотношения между величинами (цена, } \\
\text { количество, стоимость; скорость, время, расстояние; данные } \\
\text { бытовых приборов учёта расхода электроэнергии, воды, газа) }\end{array}$ \\
\hline Визуальная & $\begin{array}{l}\text { П11-Мат2: выполнять измерения и вычисления длин, } \\
\text { расстояний, углов, площадей, необходимые в жизни; площади } \\
\text { поверхности и объема прямоугольного параллелепипеда в } \\
\text { практических ситуациях; оценивать и сопоставлять } \\
\text { (сравнивать) размеры реальных объектов }\end{array}$ \\
\hline $\begin{array}{l}\text { П1-Мат2: оперировать понятиям: множество, элемент } \\
\text { множества, подмножество, пересечение, объединение } \\
\text { множеств; множество целых чисел, множество рациональных } \\
\text { чисел; использовать графическое представление множеств для } \\
\text { описания реальных процессов и явлений, при решении задач } \\
\text { из других учебных предметов }\end{array}$ \\
\hline Языковая
\end{tabular}

Таким образом, сопоставляя компоненты функциональной грамотности и образовательные результаты, приведенные в тексте ФГОС ОО, нами были сделаны следующие выводы:

1. Соотнося личностные результаты образования с элементами функциональной грамотности, мы взяли, для примера, результаты гражданского воспитания. Очередная проблема, с которой мы сталкиваемся, связана с недостаточной конкретизацией ожидаемых результатов. Попытка ослабить эту проблему приводит, в частности, к эволюции стандартов, но окончательно ее не решает. Более сложный, но и самый продуктивный способ логическая конкретизация как разбиение одного понятия на совокупность более мелких. Но для этого нужно подобрать некоторое логическое основание, в качестве которого мы настоятельно рекомендуем использовать системнодеятельностный подход как наиболее соответствующий смыслу функциональной грамотности. Иными словами, мы должны определить, что должен делать обучающийся, отвечающий требованиям к соответствующему результату. 


\section{ТРАДИЦИИ И ИННОВАЦИИ В СОВРЕМЕННОЙ НАУКЕ И ОБРАЗОВАНИИ: ТЕОРИЯ И ПЕРЕДОВАЯ ПРАКТИКА}

2. Федеральные государственные образовательные стандарты определяют результаты образования соответствующей ступени общего среднего образования на весь период реализации ООП. Для основного общего образования это период в 5 лет. Естественно, эти результаты могут быть прописаны только в достаточно общем виде. Текущее же планирование учебной деятельности требует гораздо более детального планирования. И чем конкретнее мы представляем желаемый результат определенного образовательного действа, тем эффективнее его достигаем.

Требование конкретизации, выдвигаемое к метапредметным результатам, является гораздо более строгим, нежели к результатам личностным по той простой причине, что оценка эффективности личностного развития отдельного школьника не допускается (мы не можем выставлять оценку, например, за гражданское самосознание). А оценивать степень достижения школьником метапредметных результатов можем и должны. К слову, в анализируемом ФГОС (обратите внимание) метапредметные результаты прописаны четче личностных и деятельностном формате. Проиллюстрируем сказанное на первом же метапредметном результате (M1-1): «переводить практическую ситуацию в учебную задачу». Этот результат сформулирован настолько четко, что конкретизировать его можно только обозначая учебный предмет («... в учебную задачу по физике») или тему урока, в чем, на данном этапе, нет никакого смысла.

Однако, давайте с учетом сказанного посмотрим все результаты формирования коммуникативных УУД и попытаемся конкретизировать с использованием содержания видов функциональной грамотности, с ними соотнесенных, отвечая на вопрос: «Что делает ученик, способный осуществлять конкретное УУД» (табл.4)?

Таблица 4

\section{Соотношение коммуникативных УДД с деятельностью обучающегося}

\begin{tabular}{|l|l|}
\hline \multicolumn{1}{|c|}{ Коммуникативные УУД } & \multicolumn{1}{|c|}{ Деятельность } \\
\hline Владеть смысловым чтением & Отбирает информацию, необходимую для \\
текстов разного вида, жанра, стиля с & решения практической задачи, из имеющейся; \\
целью решения различных учебных & осуществляет поиск недостающей информации \\
задач, для удовлетворения & Переводит полученную информацию на другой \\
познавательных запросов и & язык (бытового общения, схемы, графики и т.п.) \\
интересов - определять тему, & Организовывает информацию, предоставленную в \\
главную идею текста, цель его & различных формах \\
создания & \\
\hline
\end{tabular}




\begin{tabular}{|c|c|}
\hline $\begin{array}{l}\text { Устранять в рамках общения } \\
\text { разрывы в коммуникации, } \\
\text { обусловленные непониманием / } \\
\text { неприятием со стороны собеседника } \\
\text { учебной задачи, формы или } \\
\text { содержания диалога }\end{array}$ & $\begin{array}{l}\text { Идентифицирует проблемы, возникающие в ходе } \\
\text { коммуникации, и оценивает их влияние на } \\
\text { решение практической задачи } \\
\text { Принимает обоснованное решение о погашении } \\
\text { или актуализации конфликта в целях } \\
\text { эффективного достижения цели } \\
\text { Выстраивает диалог в соответствии с выбранным } \\
\text { способом разворачивания конкретной ситуации }\end{array}$ \\
\hline $\begin{array}{l}\text { Выявлять детали, важные для } \\
\text { раскрытия основной темы, } \\
\text { содержания текста, выступления, } \\
\text { диалога }\end{array}$ & $\begin{array}{l}\text { Формулирует вопрос в соответствии с ситуацией } \\
\text { диалога и его целью } \\
\text { Формулирует исследовательский вопрос и } \\
\text { выстраивает структуру ответа }\end{array}$ \\
\hline $\begin{array}{l}\text { Определять жанр выступления и в } \\
\text { соответствии с ним отбирать } \\
\text { Содержание коммуникации, } \\
\text { учитывать особенности аудитории }\end{array}$ & $\begin{array}{l}\text { Идентифицирует ситуацию по жанру и характеру } \\
\text { текста (высказывания) } \\
\text { Применяет правила общения, адекватные } \\
\text { ситуации и содержанию коммуникации }\end{array}$ \\
\hline $\begin{array}{l}\text { Определять содержание } \\
\text { выступления в соответствии с его } \\
\text { жанром и особенностями аудитории }\end{array}$ & $\begin{array}{l}\text { Идентифицирует ситуацию по жанру и характеру } \\
\text { текста (высказывания) } \\
\text { Применяет правила общения, адекватные } \\
\text { ситуации и содержанию коммуникации }\end{array}$ \\
\hline $\begin{array}{l}\text { Соблюдать нормы публичной речи и } \\
\text { регламент }\end{array}$ & $\begin{array}{l}\text { Отдает предпочтение регламенту как договору о } \\
\text { правилах взаимодействия, управляя эмоциями и } \\
\text { иными мешающими факторами } \\
\text { Использует речевые формы, соответствующие } \\
\text { ситуации } \\
\text { Опирается на правовые и моральные нормы в } \\
\text { ситуации публичного противостояния }\end{array}$ \\
\hline $\begin{array}{l}\text { Адекватно теме и ситуации общения } \\
\text { использовать средства речевой } \\
\text { выразительности для выделения } \\
\text { смысловых и эмоциональных } \\
\text { характеристик своего выступления }\end{array}$ & $\begin{array}{l}\text { Выстраивает письменный и устный текст с } \\
\text { учетом ситуации. } \\
\text { Грамотно использует нормы произносительные, } \\
\text { нормы лексики, грамматики, орфографии и } \\
\text { пунктуации. }\end{array}$ \\
\hline $\begin{array}{l}\text { Публично представлять полученные } \\
\text { результаты практической } \\
\text { экспериментальной или } \\
\text { теоретической исследовательской } \\
\text { деятельности }\end{array}$ & $\begin{array}{l}\text { Логично и последовательно выстраивает свою } \\
\text { речь } \\
\text { Использует средства наглядного представления } \\
\text { информации, адекватные задачам } \\
\text { Аргументирует свои высказывания, ссылаясь на } \\
\text { авторитетные мнения и источники }\end{array}$ \\
\hline
\end{tabular}

\section{3. Конкретизировать содержание предметной составляющей} функциональной грамотности - пожалуй самая сложная задача. В качестве примера мы используем образовательные результаты обучения школьников математике, учитывая, что математическая компетентность во всем мире считается базовой компетентностью, коррелирующей практически со всеми видами грамотности (не только функциональной). 
Многие математические компетенции могут формироваться или закрепляться на учебных занятиях других предметов. Не будем выискивать примеры - это все учебные задания, которые так или иначе содержат фигуры, расстояния, движение, зависимости и т.п. - всё, что может быть описано с использованием языка математики. Очевидно, формирование математической компетентности в строго предметном смысле этого слова - задача исключительно уроков математики. Вряд ли сможем проиллюстрировать на уроках математики, например, квадратный трехчлен или квадратичную функцию. Но что касается математической функциональной грамотности, к ее формированию в обязательном порядке должны быть причастны все учителя предметники без исключения.

Подчеркнем, трактовка деятельностного содержания результатов образования имеет категорически важное значение, так как именно она в итоге определяет конкретные цели различных образовательных событий. Чтобы соединить функциональную грамотность и результаты образования, мы вначале соотнесли их друг другу, а потом, с учетом выявленного соответствия, конкретизировали действия учеников, определяющие достижение ими очерченных результатов.

\section{Список литературы}

1. Бабикова Н.Н. Планирование предметных результатов обучения на основе компетенций ФГОС// Проблемы современного образования. - 2018. - № 6. - C. 124-133.

2. Басюк В.С. Личностные результаты освоения основных образовательных программ обучающимися в условиях реализации ФГОС общего образования// Развитие личности. - 2017. - № 3. - С. 29-43.

3. Басюк В.С., Мухачева Л.В. Совершенствование механизмов оценивания личностных результатов освоения обучающимися основных образовательных программ в условиях модернизации технологий и содержания обучения и в соответствии с федеральными государственными образовательными стандартами общего образования// Отечественная и зарубежная педагогика. - 2018. - № 4. - С. 86-102.

4. Имакаев В.Р. Метапредметные и личностные результаты в общем образовании: от декларации к гарантии качества//Школьные технологии. 2013. - № 2. - C. 10-14. 
5. Проект Федерального государственного образовательного стандарта основного общего образования [Электронный ресурс] //Федеральный портал проектов нормативных правовых актов, 2021. - URL: https://regulation.gov.ru/ projects\#npa=94555 (дата обращения 17.12.2020).

6. Тестов В.А. О некоторых видах метапредметных результатов обучения математике// Образование и наука. - 2016. - № 1 (130). - С. 4-20.

7. Федеральные государственные образовательные стандарты [Электронный ресурс] // Национальная ассоциация развития образования и науки, 2021. - URL: https://fgos.ru/ (дата обращения 12.11.2020).

8. Чошанов М.А. Образование и национальная безопасность: системные ошибки в математическом образовании России и США//Образование и наука. 2013. - № 8 (107). - С.14-31. 
УДК 159.99

\title{
ОРГАНИЗАЦИЯ ДЕЯТЕЛЬНОСТИ ПСИХОЛОГИЧЕСКОЙ СЛУЖБЫ ВУЗА В УСЛОВИЯХ ДИСТАНЦИОНОГО ОБУЧЕНИЯ
}

\author{
Бура Людмила Викторовна \\ к. психол. н., доцент \\ Залевская Яна Геннадиевна \\ ассистент \\ Гуманитарно-педагогическая академия (филиал) \\ ФГАОУ ВО «КФУ им. В.И. Вернадского» (г. Ялта)
}

\begin{abstract}
Аннотация: в статье рассмотрены особенности формирования и функционирования психологической службы вуза, в частности, в условиях дистанционного обучения. Представлена методология и методы работы службы, предполагаемая структура. Определены основные направления работы психологической службы вуза по различным аспектам развития и жизнедеятельности студентов.
\end{abstract}

Ключевые слова: психологическая служба, высшая школа, дистанционное обучение.

\section{ORGANIZATION OF THE PSYCHOLOGICAL SERVICE OF THE UNIVERSITY IN THE CONDITIONS OF DISTANCE LEARNING}

\section{Bura Lyudmila Viktorovna Zalevskaya Yana Gennadievna}

\begin{abstract}
: the article examines the features of the formation and functioning of the psychological service of the university in the context of distance learning in particular. The methodology and methods of operation of the service and the proposed structure are presented. The main directions of the work of the psychological service of the university on various aspects of the development and life of students are determined.
\end{abstract}

Key words: psychological service, higher school, distance learning. 
Инновационные процессы, происходящие в высшей школе, вызванные активным внедрением дистанционных образовательных технологий, требуют трансформации образовательной парадигмы для подготовки конкурентоспособного специалиста на мировом рынке труда. В то же время, конкурентоспособность современных выпускников включает в себя не только профессиональные знания, умения и навыки, но и особые качества личности, которые обеспечивают профессиональный динамизм поведения, самостоятельность в поиске и усвоении новой информации, адекватность решений в «нестандартных ситуациях».

На сегодняшний день востребованность специалистов диктуется не только необходимой квалификацией, но и наличием определенных компетенций, таких, как: умение взаимодействовать с людьми в онлайнформате, разрешать конфликтные ситуации, принимать нестандартные решения, ориентироваться в новой ситуации, адаптироваться к новым условиям жизни. Формирование и развитие этих компетенций - важная задача современного учебного заведения.

Сегодня от молодого профессионала требуется не столько какая-то специальная информация, сколько способность ориентироваться в информационных потоках, быть мобильным, изучать новые психологические технологии, применять самоанализ, искать и применять недостающие знания или другие ресурсы. От молодых специалистов ожидается наличие ключевых компетенций:

- готовность модернизировать профессиональную квалификацию, широко используя самообразование;

- навыки и возможности делового общения, включая сотрудничество, командную работу;

- умение работать с разными источниками информации (поиск, обработка, хранение, воспроизведение);

- способность действовать и определять обязанности и ответственность в нестандартных и неопределенных ситуациях;

- умение критически мыслить, осуществлять деятельность по самоуправлению;

- готовность эффективно вести себя в конкурентной среде с учетом стрессоров.

Для формирования продуктивной профессиональной позиции будущего специалиста необходимо социально-психологическое сопровождение студента 
на протяжении всех этапов обучения в высшей школе, которое будет содействовать расширению его внутреннего личностного пространства, самосовершенствованию, рефлексии и развитию способов самопознания. Поэтому, на современном этапе развития системы высшего образования в условиях дистанционного обучения актуальным является социальнопсихологическое сопровождение профессионального становления студентов, которое призвано повысить качество их подготовки как будущих специалистов.

Дистанционное обучение представляет собой организацию учебного процесса, при которой разработка учебной программы основана на самостоятельном образовании обучающегося. Основной особенностью такой организации образования является отдаленность участников образовательного процесса друг от друга в пространстве или времени, в то же время студенты и преподаватели имеют возможность вести диалог между собой с помощью телекоммуникационных средств [1, с.21]. Необходимость экстренного распространения дистанционного обучения в условиях пандемии оказало влияние на образовательное пространство вуза, под которым мы понимаем определенную территорию, связанную с масштабными явлениями в области образования, определенную часть социальной сферы, в рамках которой осуществляется нормированная образовательная деятельность [2, с.23].

В образовательном пространстве вуза выделим такие составляющие как: учебный и воспитательный процессы и не институциональные формы образования (институт кураторов, школа вожатых, студенческие научные общества и т.д.). С нашей точки зрения, одним из важнейших элементов образовательного пространства в условиях дистанционного обучения должна стать именно психологическая служба, которая призвана обеспечить включение студента в образовательное пространство вуза через преодоление личностных проблем будущего специалиста и развитие профессиональной идентичности $[3$, c. 116$]$.

Сегодня в Российской Федерации уже существует определенный опыт в реализации психологической помощи участникам образовательного процесса в высших учебных заведениях, но проблема заключается в том, что опыт психологической службы в вузе небольшой и практически дублирует психологическую службу в среднем учебном заведении, без учета специфики высшего образования и условий дистанционного обучения. Поэтому психологическая служба вуза требует определенной реорганизации, учитывающей современные потребности общества. 


\section{ТРАДИЦИИ И ИННОВАЦИИ В СОВРЕМЕННОЙ НАУКЕ И ОБРАЗОВАНИИ: ТЕОРИЯ И ПЕРЕДОВАЯ ПРАКТИКА}

Кроме обучающихся, участниками образовательного процесса являются преподаватели, аспиранты, соискатели, администрация, учебновспомогательный персонал, нуждающиеся в психологическом сопровождении, так как существующая система повышения квалификации специалистов не способна решить весь спектр задач, стоящих перед ней.

Таким образом, в условиях дистанционного обучения необходим целостный подход к оказанию психологического сопровождения всем участникам учебно-воспитательного процесса вуза. Мы считаем, что цель психологической службы - обеспечить реализацию профессионального, личного и творческого потенциала личности, создать условия для самореализации участников образовательного процесса, оказать психологическую поддержку и помощь в современных социальных и эпидемиологических условиях. Кроме того, психологическая служба может существенно повлиять на развитие профессиональной идентичности студентов, личностного роста, лидерских качеств, коммуникативных способностей и т.д.

Н.В. Чепелева в своих исследованиях указывает основные направления работы психологической службы в вузе:

- психодиагностическая работа среди студентов;

- психопрофилактическая работа среди студентов и преподавателей;

- психокоррекционная работа среди студентов (в случае недостаточности психопрофилактической работы и при необходимости, своевременности и эффективности применения методов психокоррекции и общей психотерапии);

- консультативная работа по заказу студентов и преподавателей;

- просветительская работа по разъяснению актуальных проблем и методов психологии [4, с.65].

Результаты проведенного мониторинга свидетельствуют, с одной стороны, об активизации развития психологической службы в вузах, с другой об отсутствии единой, четко определенной структурно-функциональной организации такой службы. Сегодня в Российской Федерации присутствуют различные организационные формы психологического сопровождения в вузе: должность психолога, психологический центр, психологический кабинет, психологическая служба, психологическая лаборатория, группа практической психологии, психологический сектор, психологический отдел и т.д. Но количество психологических служб в вузах, на данный момент, очень мало и их деятельность затруднена или приостановлена в условиях дистанционного обучения. 


\section{ТРАДИЦИИ И ИННОВАЦИИ В СОВРЕМЕННОЙ НАУКЕ И ОБРАЗОВАНИИ: ТЕОРИЯ И ПЕРЕДОВАЯ ПРАКТИКА}

Удовлетворение большинства вузов насущными потребностями психологического сопровождения учебно-воспитательного процесса осуществляется научно-педагогическими и педагогическими работниками при отсутствии надлежащего финансирования и материально-технического обеспечения - на волонтерских началах, что вызвано возрастающей потребностью в данном виде услуг [5, с.20].

Результаты анализа информации из отчетов вузов показывают, что в психологических службах вузов практически отсутствуют ставки социальных педагогов, функции которых частично выполняют практические психологи, а социально-педагогическое сопровождение учебно-воспитательного процесса осуществляется не в полном объеме - только отдельные виды работ с ограниченным количеством студентов, при отсутствии методического и материально-технического обеспечения.

В инструктивно-методических рекомендациях по деятельности работников психологической службы подчеркивается, особое внимание следует уделить выбору и созданию наиболее эффективных форм и методов индивидуальной и групповой работы психологической службы вуза со студентами и преподавателями (диагностические, консультационные, развивающие и коррекционные методики, психопрофилактические и психогигиенические мероприятия), направленные на саморазвитие и самореализацию личности, призванные способствовать процессу социальнопсихологической адаптации студенческой молодежи, а также отмечается, что психологические службы вуза нуждаются в особой помощи: организационнонормативной (документального определения организационной и функциональной структуры психологической службы и статуса ее работников); финансовой (определение и обеспечение источников финансирования и материально-технического обеспечения деятельности психологической службы); научно-методической (предоставление научно-методических рекомендаций относительно форм, методов и содержания деятельности практических психологов и социальных педагогов); информационной (обмен передовым опытом и инновационными технологиями, организация научнопрактических конференций и семинаров).

Необходимость создания и дальнейшего развития психологической службы в вузе обусловлена проблемами в системе высшего профессионального образования, особенно в становлении личности профессионала. Кроме того, в 
ходе исследования и обсуждения образовательных технологий (единства целей, методов и содержания обучения) четко понимается необходимость дидактического соответствия не только предметному содержанию, но и психологическим, социально-личностным характеристикам будущих специалистов. Современное общество столкнулось с тем, что профессиональное образование студентов не может ограничиваться только профессиографическими компонентами. Необходима всесторонняя разработка компетентностного подхода, который является частью создания условий для полноценного личностного роста будущих специалистов.

Особенно остро встает проблема создания и функционирования психологических служб в технических вузах, в которых отсутствуют кафедры психологии. При этом у студентов технических заведений выявлены такие же проблемы, как и у студентов гуманитарного профиля. Более того, возможно, именно в технических вузах психологическая служба нужнее, поскольку, если студент-гуманитарий в условиях ее отсутствия может обратиться за консультацией к психологу-преподавателю, то студенты технических вузов, как правило, лишены этой возможности.

Целенаправленная, системная деятельность психологической службы технического вуза позволит снизить остроту и выраженность студенческих проблем. Тренинговые занятия для адаптации к группе, к учебному заведению, индивидуальные и групповые занятия, консультации, психологическая профилактика и просвещение должны проводиться для студентов всех специальностей, в том числе и технических. Психологи могут консультировать студентов по вопросам самоорганизации и тайм-менеджмента, психологической готовности к сессии и поведения на экзамене, помогать справиться с эмоциональными трудностями в период адаптации, обучать приемам снятия эмоционального напряжения и саморегуляции, разрешать проблемы межличностных отношений и общения в студенческих группах. Более того, психологическая служба может во многом помочь и преподавателям технических специальностей (семинары, тренинги, психопрофилактическая работа и т.д.).

Для полноценного создания и развития психологической службы необходимо провести исследования по анализу и обобщению современного зарубежного и отечественного опыта, определить основную концепцию деятельности психологической службы, теоретико-методологические основы, 
создать соответствующую правовую базу. Однако, несмотря на недостаточность определения проблемного круга вопросов организации психологической службы в вузе, уже сейчас, учитывая опыт работы психологической службы в других социальных сферах (дошкольные образовательные учреждения, общеобразовательные учреждения и др.), можно обозначить методологические и стратегические ориентиры деятельности такой службы в образовательном пространстве вуза.

Методология организации психологической службы в вузе должна содержать:

- совокупность научно-теоретических принципов ее функционирования, определяющие, сможет ли такая служба реализовать стратегические функции в процессе модернизации высшего образования;

- основные средства (кадровые, материально-технические, технологические и другие ресурсы, которыми будут решаться ее цели и задачи);

- методы работы психологов;

- ключевые правила деятельности и тому подобное.

Методологические основы деятельности психологической службы вуза включают теорию психологии развития, задачи развития и доминантную мотивацию жизнедеятельности будущих специалистов. Теоретический анализ и проведенные экспериментальные исследования показывают, что период студенчества - это решение задач развития и реализации функций, которые лежат не только в сфере профессиональной подготовки. Профессия приобретается для того, чтобы реализоваться как личность, определиться в жизненных перспективах, обеспечить себе достойную жизнь, создать семью.

С одной стороны, социум предоставляет молодежи мораторий для поиска себя и самоопределения, с другой стороны, предлагает достаточно адекватный и конструктивный образ будущего и его смысла. Это может оказать крайне негативное влияние на определение направления личного и профессионального развития субъектов образовательного пространства. Идеальный образ будущего включает в себя линию профессионального и карьерного роста, стремление к саморазвитию и самореализации, ценность семейных отношений. Это не полный перечень возрастных задач психологического развития студенческой молодежи. При этом невозможно не учитывать все эти особенности в организации высшего образования. Все доминирующие потребности студентов 
должны быть учтены, избавляясь от иллюзий, что учебные, познавательные потребности обучающихся могут минимизировать мотивацию доминирующих задач возраста. Игнорирование этого факта может обострить противоречия между мотивационным настроением молодежи и требованиями преподавателей.

Представим основные направления работы психологической службы вуза по мотивационным аспектам жизнедеятельности студентов:

- психологическое обоснование требований по созданию оптимального согласования между решением возрастных проблем жизнедеятельности студентов и процессом профессионального обучения;

- разрешение противоречий между доминирующими потребностями молодежи и игнорированием их организационными структурами вуза;

- устранение иллюзий преподавателей по доминирующей мотивационной основе учебной деятельности студентов.

Период студенчества называют вершинной фазой развития логического мышления, интуиции, произвольной избирательности познания, творческого воображения, смысловой целостности и осознания. Однако, к сожалению, в силу обстоятельств перманентно осуществляемой реформы школьного образования отдельные ученики испытывают явные недостатки, пробелы, неравенства в развитии когнитивной сферы (например, в видах мышления, памяти, восприятия или воображения), которые за годы обучения должны получить профессиональные качества и особенности. Такие студенты нуждаются в квалифицированной помощи психолога для минимизации указанных недостатков, с целью дальнейшего успешного профессионального становления. Эти проблемы должна решить психологическая служба вуза.

Основные направления работы психологической службы вуза по интеллектуальному развития студентов:

- научно-исследовательская работа;

- работа по развитию когнитивной сферы студентов;

- устранение недостатков когнитивных процессов отдельных студентов (средствами групповых тренингов развития креативности мышления и т. п.);

- индивидуальное консультирование.

Современная психологическая служба вуза - это кардинально новая служба, представляющая собой интегрированную систему, которая объединяет в себе основные структурные составляющие: пропаганду психологических 
знаний, повышение уровня духовного развития и психологической культуры обучающихся, психологическую диагностику (индивидуальную и групповую), профилактику, консультирование, социально-психологическую адаптацию студентов в учебно-профессиональной деятельности, тренинговые занятия, практические семинары и научные конференции.

Отдельно остановимся на особенностях деятельности психологической службы в условиях дистанционного обучения. Основными целями социальнопсихологического сопровождения дистанционного обучения в системе высшего образования являются оказание психологической помощи всем участникам образовательного процесса, обеспечение их психологического комфорта в условиях пандемии [6, с.178].

Приоритетными направлениями работы психологической службы в условиях дистанционного обучения являются:

- психологическая диагностика с использованием современных методов регистрации и обработки ответов (Google-формы, онлайн-опросники и другие методы интернет-тестирования);

- психологическое консультирование с использованием средств видеосвязи (Skype, Zoom), а также мессенджеров (Viber, WhatsApp, Telegram).

- психологическое просвещение, направленное на повышение общей психологической грамотности участников образовательного процесса, работающих в сети Интернет;

- психологическая профилактика повышенной тревожности и дезадаптации, связанных с переходом в новые условия обучения (также при помощи онлайн средств).

Итак, деятельность психологической службы в условиях дистанционного обучения - это осознанный системный процесс, направленный на оказание психологической помощи всем субъектам дистанционного взаимодействия в условиях информационно-образовательного процесса.

Для успешной реализации указанных направлений деятельности, на наш взгляд, в ориентировочной психологической службе вуза должны быть представлены следующие центры: психодиагностический, научноисследовательский, психологической помощи (по личным проблемам), психологического просвещения, игровых психологических средств и психотренинга.

Анкетирование студентов позволило определить их взгляды на функции психологической службы вуза в адаптации к новым условиям обучения - 
решение личных проблем, проблем с преподавателями, помощи в трудоустройстве и адаптации к профессиональной деятельности, помощь молодым семьям. Студенты-психологи и социальные педагоги отмечают ценность практической деятельности как опыта, поэтому они предлагают себя в качестве практикантов или волонтеров этой службы.

Конечно, функции, выделяемые студентами, мы не можем рассматривать как независимые и научно обоснованные, но проведение опросов способствовало осознанию проблем деятельности психологической службы и ее места в образовательном пространстве вуза. В ходе проводимых мероприятий мы разработали модель психологической службы вуза для внедрения в работу Гуманитарно-педагогической академии (филиал) ФГАОУ ВО «КФУ им. В.И. Вернадского».

Указанная модель психологической службы университета включает в себя следующие области: работа со студентами (прохождение практики на базе службы студентами-психологами и социальными педагогами, по заказу студента и администрации, социально-психологическое сопровождение), работа с работодателями (повышение квалификации, социальнопсихологическое сопровождение выпускника, по заказу).

Дальнейшее развитие предполагает образование современного научноисследовательский комплекса, основная деятельность которого направлена на модернизацию учебно-воспитательного процесса в целях совершенствования подготовки специалистов, повышения качества психологического сопровождения и осуществляется по направлениям Микро- Макро- и Мезоструктуры его деятельности.

Микроструктура Психологической службы (работа со студентами):

- мониторинг динамики развития профессионально-личностных качеств и психологической компетентности студентов;

- адаптация студентов нового набора;

- коррекционная работа в кабинете психологической разгрузки: индивидуальное психологическое консультирование; профилактические групповые занятия; тренинги (самопознания, личностного роста, профессионального роста, общения).

2. Макроструктура Психологической службы:

- довузовская подготовка, Школа юного психолога, Университетские классы; 
- работа с абитуриентами: профотбор, профконсультирование, профориентация;

- создание системы обратной связи с выпускниками, экспресс-обучение, семинары, конференции, диагностика;

- подготовка и распространение методического инструментария и литературы;

- повышение профессиональной квалификации персонала Психологической службы;

- горячая линия.

Мезоструктура - организация научно-исследовательской работы Психологической службы (формирование, развитие, исследование индивидуально-типологических и личностных свойств субъектов образовательного пространства) включает:

- психологическое программно-целевое

моделирование профессиональной деятельности: нормативные и прогностические моделирование; выявление закономерностей достижения профессионального мастерства; разработку критериев и уровней продуктивности деятельности; составление алгоритмов продуктивного решения профессиональных задач;

- экспертный мониторинг психологической готовности к профессиональной деятельности: разработка экспертных процедур психологического анализа и прогнозирования творческой продуктивности; составление инструментария профессионально-психологической диагностики; мониторинг процессов профессиональной адаптации;

- психотехнологическое обеспечение профессиональной деятельности и подготовки кадров: разработка психотехнологий формирования и развития инновационной культуры; разработка алгоритмов деловой и личностной коммуникации, самоорганизации, саморазвития, поведения в экстремальных и особых ситуациях, реализации «Я-концепции» личности; разработка алгоритмов интеллектуальной и профессиональной безопасности организации переговоров и снятия конфликтов.

Организация деятельности психологической службы высшей школы - это целостный процесс, который соответствует экономическим характеристикам современного общества и ценностным ориентациям в области образования. Сама деятельность психологической службы вуза обеспечивает социальный порядок, а также ценностную ориентацию в области образования и, в связи с 
этим, направленна на оказание психологической поддержки личного и профессионального развития всех субъектов образовательного процесса.

Таким образом, психологическая служба высшей школы - перспективное поле для взаимодействия и взаимного обогащения теории и практики, психологической помощи и развития будущих профессионалов

Очерченный круг вопросов позволяет сделать следующие выводы:

1. На сегодняшнем этапе формирования системы высшего образования в условиях дистанционного обучения социально-психологическое сопровождение профессионального становления студентов позволит повысить качество их подготовки как будущих специалистов. Кроме того, необходим целостный подход к обеспечению социально-психологического сопровождения всех участников учебно-воспитательного процесса вуза.

2. Сегодня в Российской Федерации уже есть определенный опыт оказания помощи участникам образовательного процесса в высших учебных заведениях, но проблема в том, что опыт психологической службы в вузе невелик и практически воспроизводит психологическую службу в среднем учебном заведении без учета особенностей высшего образования и условий дистанционного обучения. Поэтому психологическая служба вуза требует реструктуризации, которая определит нормативно-правовую и методологическую основу ее функционирования.

3. Решение этой проблемы возможно путем организации и проведения Всероссийского эксперимента по разработке и тестированию различных моделей психологической службы вуза.

4. Представлена модель психологической службы вуза для внедрения в Гуманитарно-педагогической академии (филиал) ФГАОУ ВО «КФУ им В.И. Вернадского» (г. Ялта) - один из способов решения проблемы. Перспективой дальнейших исследований мы видим апробацию этой модели и мониторинг ее работы, в условиях как очного, так и дистанционного обучения.

Таким образом, психологическая служба вуза является перспективным направлением взаимодействия и взаимного обогащения теории и практики, психологической помощи и сопровождения развития будущих специалистов в современных условиях. 


\section{Список литературы}

1. Мукова, Л.А. Из практики дистанционного обучения бакалавров в вузе (социально-психологические аспекты) // Психология человека в образовании. - 2020. - №2. - С. 21

2. Шегда, О.В. Психологическая служба как элемент образовательного пространства вуза // Актуальные проблемы психологии. - 2018. - Т.7. - Вып.6. - C. 23.

3. Бура, Л.В. Психологическая служба вуза: проблемы и перспективы // Гуманитарные науки. - 2016. - №1. - С. 116.

4. Чепелева, Н.В. Психологическая служба в высших учреждениях образования // Практическая психология и социальная работа. - 2001. - №6 (33). - C.65.

5. Шкарлет, С.М. Инновационное развитие образовательного пространства в высших учебных заведениях // Вестник Черниговского государственного технологического университета. - 2018. - №2. - С. 20.

6. Романов, Е.В. Дистанционное обучение: необходимые и достаточные условия эффективной реализации // Современное образование. - 2017. - № 1. C. 172-195.

(с) Л.В. Бура, Я.Г. Залевская 
УДК 811.11-112

\title{
ОНЛАЙН-ТЕХНОЛОГИИ В ОБУЧЕНИИ ИНОСТРАННЫМ ЯЗЫКАМ: ВЗГЛЯД ИЗНУТРИ
}

Каспаров Игорь Викторович к.т.н., профессор

Попель Александр Александрович к.псих.н., доцент

Пшениснов Николай Владимирович к.э.н., доцент Самарский государственный университет путей сообщения (филиал СамГУПС в г. Нижнем Новгороде)

Аннотация: На основе SWAT анализа в статье приводится комплексный анализ применения онлайн-технологий в обучении иностранным языкам. Рассматриваются сильные и слабые стороны данного метода преподавания языка, проводится сравнительный анализ традиционных и онлайн-форм преподавания. Авторы дают определение социальной креативности, показывает ее значение в постиндустриальном обществе, а также анализирует влияние онлайн-обучения на ее развитие.

Ключевые слова: Онлайн-обучение иностранным языкам, креативный климат, социальная креативность.

\section{ONLINE TECHNOLOGIES IN TEACHING FOREIGN LANGUAGES: AN INSIDE LOOK OF}

\author{
Kasparov Igor Viktorovich \\ Popel Alexander Aleksandrovich \\ Pshenisnov Nikolai Vladimirovich
}

\begin{abstract}
Based on SWAT analysis the article looks deep into the use of online technologies in teaching foreign languages. It also considers strengths and weaknesses of online learning as contrasted to traditional ways of teaching and learning languages. The author defines social creativity, explains its importance in
\end{abstract}


postindustrial society as well as analyses how these online methods can impact of social creativity.

Key words: Online learning of foreign languages, creative climate, social creativity.

Все чаще и чаще как в научном сообществе, так и среди коллегпреподавателей нам приходиться слышать мнение о том, что переход на онлайн-технологии в образовательном процессе, в том числе в преподавании иностранного языка, знаменуют собой начало новой эры в образовании, которая неизбежно повысит его эффективность, будет способствовать наиболее полному раскрытию творческого потенциала обучающихся, предоставит последним существенно больший выбор образовательных ресурсов и пр. [1].

К достоинствам онлайн-обучения традиционно относят следующие: возможность индивидуального обучения, в том числе лиц с ограниченными возможностями здоровья, проживающими в удаленных районах и пр.; возможность обучения в лучших вузах страны без необходимости нахождения в них; возможность организовать процесс обучения в наиболее удобном временном режиме, интерактивность, обеспечение всех компонентов образовательного процесса, возможность более полноценного обучения вне аудитории.

В качестве доводов сторонники подобного формата традиционно приводят острую необходимость приведения качества вузовского образования в соответствии с требованиями современного рынка труда, которые предъявляются к молодым специалистам; желание «осовременить» существующий профессорско-преподавательский состав вузов, большую часть которого составляют люди предпенсионного или пенсионного возраста; необходимость не отставать от студентов в части использования передовых технических устройств, чувствовать себя на одной волне с ними и т.д.

В многочисленных публикациях как в российской, так и иностранной печати, авторы наяву грезят увидеть дивный новый мир образования - мир, наполненный передовыми техническими устройствами, которые были бы способны стирать границы и расстояния; искусственным интеллектом, который бы помогал и заменял (частично или полностью) преподавателя; новыми, ранее не виданными, форматами обучения, сочетающими в себе мир реального и виртуального. 
Внезапная пандемия короновируса в одночасье сделала то, о чем сторонники новых форм образования и помыслить не могли в своих самых смелых фантазиях - повсеместное закрытие образовательных учреждений и, как следствие, практически мгновенный и повсеместный переход от традиционных форм обучения к онлайн-формату, приведший к существенному расширению функций онлайн-обучения и трансформации его из вспомогательного в основной инструмент обучения в современной системе образования России [2].

В данной статье на основе SWAT - анализа мы бы хотели поделиться нашим субъективным мнением о преимуществах и недостатках онлайнобучения, опираясь на собственный опыт его практического использования в течении полугода после начала пандемии; определить дальнейшие пути развития данной формы обучения; сделать прогноз о будущем традиционного обучения.

Хотелось бы начать с того, что автор данных строк на всем протяжении своей многолетней преподавательской деятельности являлся (и является) ярым сторонником традиционных «контактных» форм обучения иностранным языкам и до последнего момента крайне скептически относился к подобному «эфемерному» способу преподавания, однако внезапные перемены не оставили ему иного выбора, как решить на испытание онлайн-обучения в деле.

Мы полагаем, что относительно небольшой срок в полгода, который прошел с момента перехода на онлайн-обучение и пока еще не угасшие свежесть и острота ощущений от его применения, позволяют нам довольно объективно проанализировать данный феномен.

Начнем с сильных сторон онлайн-обучения иностранным языкам. По сравнению с традиционными формами преподавания неоспоримым преимуществом онлайн-обучения выступает возможность выбора студентом «своего» преподавателя (в том числе и носителя языка), который бы в максимально полной мере отвечал его требованиям и ожиданиям в части уровня владения языком, режима и графика проведения занятий, выбора форм и методов обучения, психологического комфорта и пр.

На наш взгляд, данное преимущество крайне важно, поскольку ежегодно нам приходиться быть невольными свидетелями того, как те светлые, наивные и немного идеализированные ожидания студентов (особенно сразу после поступления), связанные с изучением иностранного языка, с которыми 
приходят вчерашние абитуриенты в вуз, буквально полгода спустя вдребезги разбиваются о суровый быт вузовской действительности: группы (кроме языковых специальностей) не делятся по уровню владения языком, что приводит к появлению чувства собственной неполноценности и резкому падению мотивации у студентов с более низким уровнем владения ИЯ; из-за нехватки аудиторного фонда или/и желания руководства вузов бесконечно оптимизировать фонд оплаты труда ППС редко выдерживается оптимальное количество студентов в группе (6-8 человек), необходимое для наиболее эффективного изучения языка; предлагаемые учебные материалы, как правило, являются сильно устаревшими; да и сами преподаватели зачастую, будем откровенными, тоже вносят свой «посильный» вклад в дело демотивации студентов полной теоретизацией обучения или формально-бюрократическим подходом к преподаванию $[3,4,5]$.

Мы полагаем, что формат онлайн-занятий (особенно с носителями языка соответствующего возраста) позволит сделать процесс обучения индивидуально-ориентированным, максимально эффективным, психологически комфортным и, что самое важное, наиболее полно отвечающим требованиям будущих работодателей в части качества иностранного языка.

Вторым несомненным плюсом, на наш взгляд, является резко обострившаяся конкуренция между преподавателями, практикующими онлайнуроки, вызванная лавинообразным перетоком на рынок онлайн-услуг из сферы традиционного преподавания огромного количества преподавателей непосредственно после начала пандемии.

Всплеск конкуренции привел не только к обвалу цен на онлайн - занятия (что есть несомненное благо для потенциальных желающих изучать ИЯ), но и мотивировал преподавателей искать новые, оригинальные, более эффективные формы и методы преподавания языка, выгодополучателем от которых является непосредственно сам обучающийся.

Следующим достижением онлайн-подхода к преподаванию иностранных языков является реализация на практике модели безотрывного обучения, который мы назвали «Обучение всегда со мной». Обучающийся более не привязан к конкретному образовательному учреждению (языковая школа или вуз), что существенно экономит его время и усилия, затрачиваемые на перемещения по городу, что в условиях ускоряющегося образа жизни и хронической нехватки времени делает онлайн-обучение весьма привлекательной альтернативой по сравнению с традиционными формами. 


\section{ТРАДИЦИИ И ИННОВАЦИИ В СОВРЕМЕННОЙ НАУКЕ И ОБРАЗОВАНИИ: ТЕОРИЯ И ПЕРЕДОВАЯ ПРАКТИКА}

Также существенным преимуществом онлайн-обучения иностранным языкам является возможность «вписания» интерактивного элемента в традиционные формы преподавания, что приобретает особую актуальность в связи с тем, что современные студенты, родившиеся со смартфоном в руке, крайне плохо воспринимают большие объемы текстовой информации, особенно, если она изложена тяжелым для понимания академическим стилем, отдавая предпочтение коротким по протяженности видеоматериалам или презентациям с несколько выхолощенным, но более броско и ярко представленным содержанием.

Применение интерактивных заданий также делает урок более интересным, особенно для студентов с низкими уровнями владения ИЯ, которым требуется более длительное время для закрепления полученных навыков по сравнению со своими более опытными сокурсниками.

Также интерактивный элемент (например, тематический диалог между носителями языка, записанный на видео) позволяет обучающемуся сразу же воочию увидеть практический итог его будущих усилий.

Кроме этого, проведение групповых занятий в онлайн-формате позволяет создавать группы из студентов разных национальностей, что позволяет услышать английский язык во всем многообразии акцентов и смыслов.

Общение со сверстниками из других стран также прививает слушателям навыки социально-культурного этикета, знакомит их с традициями и обычаями других народов и национальностей.

Далее перейдем к анализу слабых сторон онлайн-обучения. Исходя из отзывов студентов, полученных во время летней сессии 2020 г., наиболее распространенным недостатком (безотносительно качества самого преподавания) является отсутствие индивидуальных технических средств (смартфон, планшет, компьютер) в семьях с двумя и более детьми, отсутствие комфортного места для обучения и/или слабое интернет-покрытие в сельских районах, что либо существенно затрудняло применение подобного формата обучения, либо делало его невозможным.

Также многие студенты, вынужденные проводить бо́льшую часть дня перед экраном компьютера, жаловались на повышенную утомляемость, головную боль, снижение аппетита, резкое ухудшение зрения и ряд других проблем со здоровьем. Учитывая не слишком хорошее состояние здоровья современных студентов, можно сделать вывод о том, что увлечение подобной 


\section{ТРАДИЦИИ И ИННОВАЦИИ В СОВРЕМЕННОЙ НАУКЕ И ОБРАЗОВАНИИ: ТЕОРИЯ И ПЕРЕДОВАЯ ПРАКТИКА}

формой проведения занятий особенно в течение длительного времени либо является нежелательным, а в некоторых случаях - противопоказанным по медицинским основаниям.

Теперь остановимся на самом главном, наболевшем и наиболее обсуждаемом в средствах массовой информации недостатке онлайн-обучения его качестве.

Исходя их нашего многолетнего опыта преподавания иностранного языка, мы считаем, что подобный формат обучения идеально подходит слушателям с высокой степенью самомотивации, развитыми навыками планирования и управления собственными временными ресурсами и, что самое главное, четким пониманием целей обучения и следования им.

К сожалению, как мы все знаем, большинство студентов ничем из вышеперечисленного похвастаться не могут, что приводит к замене эффективного обучения так называемым «имитационным», когда студенты, на первый взгляд, старательно посещают занятия, прилежно выполняют домашние задания, однако в итоге демонстрируют довольно посредственные знания.

Более того, современные студенты, при всей их кажущейся взрослости и независимости, являются довольно инфантильными, что проявляется в запросе на проявлении заботы и опеки над ними, что в отсутствии реального (не виртуального) преподавателя - наставника, готового ежеминутно прийти им на помощь, приводит к усилению стресса и, как следствие, развитию апатии к изучаемой дисциплине.

Если же рассматривать онлайн-обучение с позиции преподавателя, то, несмотря на ряд очевидных сильных сторон, о которых мы писали выше, он, к сожалению, содержит довольно серьезные недостатки.

Прежде всего, это невозможность в полной мере контролировать то, чем занимается студент по ту сторону экрана - насколько полно он погружен в процесс обучения или попросту ловко имитирует его, совмещая «изучение» языка с просмотром видео, общением в соцсетях и пр.

Вторым недостатком онлайн-обучения, на наш взгляд, является существенное сужение доступных методов и обучения языку. Так, практически невозможным оказалось написание диктантов - как обычных, так и лексических, поскольку преподаватель не имел возможности полностью контролировать процесс его написания и, что особенно важно, проверки. Сначала мы просили студентов присылать фотографии написанного текста, 


\section{ТРАДИЦИИ И ИННОВАЦИИ В СОВРЕМЕННОЙ НАУКЕ И ОБРАЗОВАНИИ: ТЕОРИЯ И ПЕРЕДОВАЯ ПРАКТИКА}

однако, на присланных снимках оказалось невозможным отмечать и корректировать ошибки. Затем мы попытались писать диктанты в текстовом редакторе Word, но, во-первых, встроенная программа проверки орфографических ошибок автоматически исправляла допущенные студентами ошибки; более того, большинство студентов имело крайне низкую скорость набора текстовой информации на английском языке, что сводило смысл написания диктантов на нет.

Не меньшие трудности подстерегали нас и при работе с диалогической речью. Дело в том, что составление диалогов подразумевает вовлечение учащихся в процесс языкового сотворчества, активное взаимодействие друг с другом, живое обсуждение новых идей и сценариев развития диалога, возможность вступать в полемику с участниками, что, на наш взгляд, возможно только в режиме живого общения студентов друг с другом с постоянным вовлечением преподавателя в процесс составления диалогического высказывания. В онлайн-формате достижение всего вышеперечисленного становится крайне затруднительным, а в ряде случаев и просто невозможным прежде всего потому что на фоне постоянного шума в эфире преподаватель не имеет возможности индивидуально обратиться к каждому студенту.

Кроме этого, при онлайн-формате оказалось крайне сложно контролировать самостоятельность выполнения студентами задания, поскольку из опыта работы стало очевидно, что многие студенты выбирали путь наименьшего сопротивления и активно применяли онлайн-переводчики при составлении текстов. Также оказалось невозможно проверить, насколько правильно студенты записали составленные диалоги, в результате чего грамматические и орфографические ошибки, оставленные без внимания преподавателя, начинали повторяться в последующих работах, что приводило к их автоматизации и закреплению. Устранить подобные ошибки впоследствии оказалось крайне сложно.

Наиболее существенным недостатком, на наш взгляд, при проведении занятий в онлайн-формате является частичное или полное отсутствие паралингвистического компонента речи (мимика, жесты, позы, расстояние между собеседниками и пр.).

Как преподаватель, так и студенты лишены возможности в полной мере считывать визуальную информацию друг о друге, что может приводить к неправильной интерпретации эмоциональной обратной связи и, как следствие, 
создание неблагоприятного психологического климата в микрогруппе. Кроме этого, качество связи и возможные искажения тембра и мелодики речи учащихся не позволяет преподавателю правильно оценить их психологоэмоциональное состояние.

Еще одним важным моментом является необходимость обеспечить максимальную вовлеченность всех студентов в прослушивание и обсуждение готовых диалогов. В режиме живого общения преподаватель может попросить студентов обнаружить ошибки в диалогах своих одногрупников либо самостоятельно указать на них, проанализировать логическую структуру диалога, его лексическое и грамматическое наполнение, предложить интересные лингвистические решения (идиомы, фразовые глаголы, перефраз и пр.).

Однако больнее всего, на наш взгляд, онлайн формат обучения ударит по развитию социальной и речевой креативности студентов. Для того, чтобы лучше понять эту проблему, обратимся к истории данного феномена.

Обзор научной литературы показывает, что в последнее время наблюдается резкий рост интереса к вопросу общей способности к творчеству (креативности), выступающей, по мнению многих экономистов, одним из драйверов инновационного развития общества и экономики.

Тем не менее, несмотря на стремительный рост публикаций по данной тематике как в отечественных, так и зарубежных изданиях, в настоящее время до сих пор отсутствует устоявшаяся точка зрения относительно того, что мы вправе считать креативностью; каковы ее критерии; что заставляет человека творить; как общество воспринимает творческий продукт и пр.

Отчасти наше незнание обусловлено тем фактом, данное явление привлекло к себе внимание научного сообщества относительно недавно, а именно в лишь в начале 50-х годов прошлого века, хотя первые попытки ответить на вопрос: «Что такое творчество?» мы можем обнаружить еще в работах Аристотеля.

В последующие годы в мировой психологической науке наблюдался в буквальном смысле лавинообразный рост публикаций по теме креативности; впоследствии креативность распространила свое влияние далеко за пределы научного сообщества - стало модным быть креативным, работодатели стали включать наличие креативного мышления в обязательные требования для соискателей, появилось огромное количество псевдонаучных печатных работ, 
курсов, периодических изданий, содержащих в своем названии слово «креативный» или «креативность».

Печальным итогом стал так и не произошедший переход количество в качество, более того, чересчур обширный плюрализм мнений и богатое разнообразие конкурирующих друг с другом теорий в отношении того, что следует понимать под креативностью, способствовали еще большей неоднозначности в понимании данного явления. Еще в 60-х годах прошлого века было предложено более 60 определений креативности, причем, как можно предположить с большой долей вероятности, к настоящему моменту количество таких определений определенно увеличилось в разы.

Постепенное расширение границ того, что подпадало под определение «креативность» или «креативного», способствовало не только внесению еще большей неясности в суть изучаемого явления, но и существенно затрудняло интеграцию крайне скудных, но обладающих научной ценностью данных в единую понятийное поле. Все это все дальше и дальше уводило исследователей от истинного понимания того, что же представляет собой креативность на самом деле.

Вызовы, брошенные России странами западной Европы и США, а также пандемия Ковид-19, предельно остро обнажили несостоятельность сырьевой модели экономического развития, доминировавшей в нашей стране последние несколько десятилетий, и заложили фундамент для построения принципиально иной модели, основанной на знаниях и инновациях.

В ней основными силами экономического развития будут выступать автоматизация производства, повышение производительности труда, увеличение доли наукоемких производств, способных производить конкурентоспособные товары и услуги, одним словом, фундаментальный характер задач, которые необходимо решить для построения новой модели экономического роста означает, что необходимо не просто принять отдельные меры по его стимулированию, а провести глубокие изменения в экономической политике и в системе государственного управления, внедрив в них сильные стимулы к повышению эффективности.

Однако, несмотря на достигнутые положительные изменения в виде существенного улучшения материально-технического оснащения промышленных предприятий, роста заработных плат в оборонной и обрабатывающих секторах экономики и пр., на второй план отошел 
непосредственно сам человек, уступив место все возрастающей технизации и автоматизации.

Учитывая глобальные процессы роботизации, выражающиеся во все большем отчуждении человека от продуктов его материальной деятельности и, как следствие, высвобождение все большего количества рабочей силы; изменение самой природы труда, связанной с трансграничностью работника и его работодателя, а также общим ускорением ритма социальной жизни человека, особое внимание следует уделять способности человека творчески и эффективно решать нестандартные проблемы не только в его профессиональной деятельности, но и в области его социального взаимодействия.

Таким образом, особую актуальность приобретает общая способность к творчеству, понимаемая как креативность, и ее социальная разновидность (социальная креативность), определяемая нами как способность человека оперативно находить и эффективно применять нестандартные, оригинальные творческие решения ситуаций межличностного взаимодействия [6].

Для развития социальной креативности необходимо создание особой среды, поскольку, согласно данным генетических исследований, креативность существенно зависит от средовых факторов.

Основное назначение творческой среды - максимально способствовать генерированию, анализу (осмыслению) и практическому применению новых, не встречавшихся ранее идей.

В работах отечественных и зарубежных авторов представлены некоторые основные характеристики творческой среды: неопределенность, многовариативность, нерегламентируемость поведения субъекта творчества, предметная обогащенность среды, свобода выбора.

Следует, однако, учитывать и тот факт, что степень мотивированности субъекта имеет тенденцию резко снижаться при отсутствии положительного отклика со стороны преподавателя. Следовательно, одной из приоритетных задач преподавателя является нахождение индивидуальных мотиваторов для каждого обучаемого и построение на их основе такой модели внутригруппового климата, которая способствовала бы их постоянной активизации.

Важным психологическим условием, влияющим на развитие социальной креативности студентов, является модель творческого поведения педагога, преподавателя. Этот фактор может быть включен в число условий, составляющих творческую среду. 


\section{ТРАДИЦИИ И ИННОВАЦИИ В СОВРЕМЕННОЙ НАУКЕ И ОБРАЗОВАНИИ: ТЕОРИЯ И ПЕРЕДОВАЯ ПРАКТИКА}

В процессе преобразования потенциальной креативности в реальную выделяют выделяет несколько этапов: 1) подражание образцу (копирование); 2) творческое подражание; 3) репродуктивное (подражательное) творчество; 4) подлинное творчество (созидание).

Очевидно, что трансформация «первичной» креативности в подлинное творчество на большинстве этапов неизбежно опирается на модель творческого поведения педагога, что подчеркивает ту ответственность, которая возлагается на преподавателя как организатора и носителя творческой среды.

Одним из наиболее противоречивых в креативной педагогике является вопрос о роли и месте контроля в процессе творчества. Решение подобной противоречивой ситуации мы находим в работе Дж. Баркер [7]. Как отмечает автор, оптимальную творческую среду отличают отсутствие именно жесткого, непосредственного контроля (в противовес контролю «направляющему») и каких-либо норм поведения, регламентирующих ее. Наставник творчества лишь определяет границы творчества, в которых предстоит творить креативной личности, выбор же средств и методов достижения поставленной цели находится полностью за последней.

Комплексный подход к пониманию социальной креативности как системы мотивационных, интеллектуальных, эмоциональных, волевых, ценностных и нравственных характеристик личности предполагает, что развитие социальной креативности - это процесс, направленный на все стороны личности, на целостную личность. Это означает, что ориентация учебновоспитательного процесса на развитие целостной личности является одним из главнейших условий становления и развития социальной креативности студента [8].

Актуальность развития социальной креативности студентов обусловлена особенностями сферы межличностного общения в студенческом возрасте, на который приходится один из пиков развития коммуникативного потенциала, значительными изменениями в системе общения студентов с родителями, а также рядом негативных тенденций возраста, обусловленных следующими факторами:

1. Социальные факторы, являющиеся следствием глобальной невротизации населения планеты вообще.

2. Психологические факторы, которые связаны с взаимоотношениями человека в различных микрогруппах (отношения в семье, психологическая 
несовместимость между членами группы, проживающими в общежитии, взаимоотношения в учебном коллективе).

3. Психолого-педагогические причины неврозов у студентов отмечаются в $40 \%$ случаев. К их числу относятся преимущественно адаптационные трудности.

Таким образом, проделанный нами анализ позволяет выделить следующие основные социально-психологические условия развития социальной креативности студентов:

- направленность психологической подготовки на целостную личность студента - будущего специалиста в совокупности мотивационных, интеллектуальных, эмоциональных, волевых и ценностно-смысловых характеристик; важным условием при этом является учет главнейших возрастно-психологических особенностей студентов;

- создание в учебной формирующей работе со студентами предметно обогащенной, нежестко регламентированной, многовариативной коммуникативно-творческой среды, которая бы предоставляла обучаемому максимальные возможности свободы выбора;

- важнейшим фактором создания творческой среды является личность педагога, система профессионально важных качеств которого (стиль общения и преподавания, профессионализм общения, эмпатийные способности, конгруэнтность, необходимый уровень социальной креативности и др.) является катализатором творческого развития студентов;

- организация инновационной учебной деятельности, включающей активное использование социально-психологического тренинга и коммуникативно-ориентированных деловых игр;

- обеспечение взаимосвязанной когнитивной, мотивационной, рефлексивной, операциональной, ценностно-смысловой и духовнонравственной подготовки студентов в рамках специальной программы целенаправленного формирования социальной креативности.

На наш взгляд, представляется достаточно затруднительным создание подобной творческой среды при проведении занятий в онлайн-формате, что неизбежно приведет к снижению как творческого потенциала, так и общей мотивации к изучаемой дисциплине. Преподаватель, лишенный живого общения со студентами, в лучшем случае будет выступать хорошим ретранслятором готовых знаний, говорить же о нахождении индивидуального 
подхода к каждому обучающемуся, а тем более о развитии его творческих способностей не представляется возможным.

Таким образом, мы можем заключить, что, несмотря на определенные преимущества, онлайн-формат проведения занятий по иностранному языку еще пока слабо отвечает потребностям студентов и преимущественно предназначен для людей более старшего возраста с сильным тайм-менеджментом и четким пониманием целей и задача изучения иностранного языка.

\section{Список литературы}

1. Амирова Е. А. Об использовании вебинара в дистанционном обучении иностранному языку // Филологические науки. Вопросы теории и практики. Тамбов: Грамота, 2014. № 8 (38). Ч. 2. С. 15-17.

2. Минобрнауки рекомендовало вузам организовать дистанционное обучение. URL: http: https://rg.ru/2020/03/15/minobrnauki-rekomendovalo-vuzamorganizovat-distancionnoe-obuchenie.html (дата обращения: 5.02.2021).

3. Каспаров И.В., Пшениснов Н.В. Проблема противоречий при внедрении информационных технологий в образовательный процесс. В сборнике: Перспективы развития науки и образования. Сборник научных трудов по материалам $\mathrm{V}$ международной научно-практической конференции. Под общей редакцией А.В. Туголукова, 2016. С. 10-12.

4. Каспаров И.В., Пшениснов Н.В. Педагогические проблемы при вхождении в информационное общество. В сборнике: Перспективы развития науки и образования. Сборник научных трудов по материалам V международной научно-практической конференции. Под общей редакцией А.В. Туголукова, 2016. С. 13-14.

5. Каспаров И.В., Пшениснов Н.В. Проблемы внедрения информационных технологий при изучении специальных дисциплин в технических вузах. В сборнике: Перспективы развития науки и образования. Сборник научных трудов по материалам $\mathrm{V}$ международной научнопрактической конференции. Под общей редакцией А.В. Туголукова, 2016. С. 8-10.

6. Попель А.А. Психологические условия развития социальной креативности студентов в процессе профессиональной подготовки: автореферат дис. канд. психол. наук. Нижний Новгород, 2005. 24 с. 
7. Barker J. Bright lights // Sales \& Marketing Management. 1995. Vol. 147. P. $524-527$.

8. Попель А.А. Теоретические подходы к трактовке социальной креативности в отечественной и зарубежной науке // Вестник Нижегородского университета им. Н. И. Лобачевского. Сер. Социальные науки. 2015. № 4. С. 96103.

(С) И.В. Каспаров, А.А. Попель, Н.В. Пшениснов, 2021 
УДК 372.881.111.1

\title{
ИГРОВЫЕ ТЕХНОЛОГИИ И ИХ МЕСТО В ОБУЧЕНИИ ИНОСТРАННОМУ ЯЗЫКУ
}

\author{
Чурюканова Елена Олеговна \\ к.ф.н., доцент
}

ГОУ ВО МО «Государственный гуманитарно-технологический университет»

Аннотация: В работе рассматриваются вопросы организации современного урока иностранного языка с учетом требований Федерального государственного образовательного стандарта. Определяется понятие педагогической технологии. Анализируется современный подход к структуре урока с четом физиологических и психологических возрастных особенностей школьников. Описывается преимущество игрового подхода к организации урока и анализ игровых технологий в образовательном процессе.

Ключевые слова: Федеральный образовательный стандарт, познавательная деятельность, педагогические технологии, интерактивность, игровые технологии.

\section{GAME TECHNOLOGIES AND THEIR PLACE IN TEACHING A FOREIGN LANGUAGE}

\section{Churiukanova Elena Olegovna}

Abstract: The paper deals with the organization of a modern foreign language lesson, taking into account the requirements of the Federal State Educational Standard. The concept of pedagogical technology is defined. The modern approach to the structure of the lesson is analyzed, taking into account the physiological and psychological age characteristics of schoolchildren. The advantage of the game approach to the organization of the lesson and the analysis of game technologies in the educational process are described.

Key words: Federal State Educational standard, cognitive activity, pedagogical technologies, interactivity, game technologies. 
Перед современным педагогом стоит нелегкая задача поиска новых эффективных методов обучения иностранному языку в средней школе, что, безусловно, отражается на модификации форм организации познавательной деятельности учащихся на уроке.

Как бы далеко не зашла педагогическая мысль, традиционной формой организации работы учащихся в школе является урок. Однако следуя правилам и тенденциям современности, педагогу необходимо изменить подход к структурированию урока, поскольку залог успешной организации работы учащихся кроется в продуманном планировании этапов, целеположении и реализации учебных задач.

Дидактические требования к уроку предполагают наличие оптимального содержания, отражающего учебный материал модуля, гармоничное сочетание традиционных и современных методов, соблюдения основополагающих принципов обучения иностранному языку.

Современная педагогика предъявляет особые психологические требования к организации учебной деятельности школьников. Поскольку главным условием успешного овладения учебным материалом по иностранному языку является позитивное отношение к самой учебной деятельности, педагог сталкивается с трудностью поддержания мотивации школьников и формирования положительного отношения к предмету обучения.

Помимо создания позитивного учебного настроя и психологического микроклимата в учебной группе, перед педагогом стоит важная этическая задача, отражающая основополагающую сторону современной педагогической морали, а именно межличностные отношения между педагогом и учеником. От учителя требуются личные качества, особый такт и проникновение в профессию, чтобы суметь создать корректные отношения с учениками. Это становится особенно важным для современного ученика, особо чувствующего тип отношений, выстраиваемых педагогом, поскольку формализация образовательного процесса утрачивает свою значимость сначала в школе, а потом и в обществе.

Для продуктивной работы на уроке всем участникам педагогического процесса необходимо соблюдать взаимоуважение, это актуально как со стороны учащихся, так и стороны учителя. Уважение чужого мнения, способность к адекватному восприятию ситуации и корректное ведение педагогической ситуации способствует созданию благоприятной продуктивной 
рабочей атмосферы на уроке. Одним из проявлений уважения к ученику является оптимальная требовательность учителя, поскольку отсутствие требовательности, как и завышенная требовательность способствует понижению мотивированности учащихся.

Оценивание знаний учащихся является важным и тонким инструментом формирования определённого отношения ученика к предмету и учебной деятельности. Оценивание знаний предполагает наличие у педагога этических норм, поскольку необъективная оценка знаний может негативно повлиять на учебную работу школьника и сформировать прочное отрицательное отношение к предмету и учителю. На наш взгляд, отрицательная оценка является инструментом наказания, не повышает мотивированность школьника, поэтому, прежде чем учитель выставит отрицательную оценку, он должен проанализировать, насколько оправдан данный факт с точки зрения формирования положительного отношения к учебной деятельности. Однако для объективного оценивания учебной деятельности педагог должен применять инструменты негативного оценивания (например, различные формы ранжирования результатов работы школьников).

Этическая составляющая образовательной деятельности педагога представляет собой одну из самых важных сторон педагогической работы. Проникновение своей миссией, вера в ребёнка, положительный настрой, способность к постоянному развитию, уважение своих подопечных и коллег эти качества современного учителя делают его работу неоценимой для настоящего и будущего нашего общества. Учитель связывает воедино несколько поколений, более того, он способен формировать пути развития будущих поколений и, как следствие, будущее нашей страны.

Помимо этических требований к организации педагогической деятельности, важную роль играют санитарно-гигиенические факторы.

Санитарно-гигиенические требования концентрируют внимание учителя на ответственности не только за глубокие и фундаментальные знания детей, но и за их психофизиологическое самочувствие.

В течение урока он обязан следить за уровнем утомляемости учеников. Это необходимо для поддержания продуктивной работы на уроке. Возникновение усталости неизбежно, это естественный физиологический процесс, который имеет две фазы: подвижной неусидчивости и заторможенности. Если ученик начинает отвлекаться от работы, заниматься 
посторонними делами, разговаривать - это признак первой фазы усталости. Вялость, апатия, зевота, рассеянность свидетельствуют о возникновении заторможенности. Для того чтобы избежать второй фазы усталости, необходимо дать учащимся кратковременный отдых или предложить им другой вид деятельности.

На работоспособность обучающихся влияет и мебель, на которой они сидят. Несоответствие высоты парт вызывает психологический дискомфорт, может привести к нарушению осанки и зрения детей. Усталость учеников могут повлечь теснота, духота, повышенная влажность, химический состав воздуха (воздух, в котором 0,1\% углекислого газа, является неблагоприятным для пребывания человека). Поэтому проветривания класса являются обязательным санитарно-гигиеническим требованием к организации учебного процесса.

При анализе этапов урока, учителю необходимо помнить, что однообразная, рутинная работа способствует повышению утомляемости школьников. По мнению физиологов, у 90\% обучающихся усталость во время школьной деятельности возникает не от недостатка энергии, а от ее избытка. Учащиеся подвержены большей утомляемости на неинтересных. Однообразных уроках, чем на уроках, наполненных напряженным, интересным содержанием, требующих активной мыслительной работы. Именно поэтому современный педагог должен умело использовать интонационные средства языка, следить за громкостью и интенсивностью речи, то есть использовать свой голос как важный педагогический инструмент. Кроме того, эффективным способом снижения утомляемости школьников является рациональное чередование различных методов обучения, использование игровых технологий, создание ситуации активной занятости и эмоционального переживания.

Для современного учителя английского языка обязательным требованием является умение использовать актуальные методы обучения, стимулирующие школьников к творческой, продуктивной деятельности, мотивирующие стремление к активной работе на уроке, самостоятельной работе по овладению навыками иноязычной речи, общению и выражению собственных мыслей на иностранном языке. Обозначенным требованиям как нельзя лучше соответствуют интерактивные методы обучения.

Интерактивное обучение является одним из актуальных способов организации образовательной деятельности, предполагающий активное взаимодействие всех участников педагогического процесса, в результате чего 
обучающийся вступает в диалог с учителем или другими учениками, проявляет активное участие в познавательном процессе, выполняя творческие, поисковые, проблемные задачи в паре или группе.

К источникам учебной активности ученика относятся его личная мотивация и потребности; учебная среда, в которой он формируется; личность и авторитет учителя, его этические качества и профессиональные; уровень знаний одноклассников как партнеров в школьном общении, наличие общих интересов; средства деятельности; формы речевого и социального взаимодействия, используемые в обучении.

В процессе освоения учениками нового иноязычного средства общения формируется правильное понимание английского языка как социального явления, как важного коммуникативного инструмента межкультурного общения, развиваются интеллектуальные, речевые и эмоциональные способности, а также формируются личностные качества, общечеловеческие ценности, интересы, воля и трудолюбие.

Важно подчеркнуть, что английский язык - один из самых распространенных языков на планете. Во всем мире существует более 350000 000 людей, для которых английский язык не является родным, но они знают его и активно пользуются им в повседневном и профессиональном общении.

Для того чтобы английский язык стал инструментом живого межкультурного общения, школьникам необходима аудиовизуализация дисциплины, то есть использование различных информационнокоммуникационных технологий, способствующих формированию аудиовизуального представления английского языка и иноязычной речи. Решению указанных задач способствует технологизация учебного процесса. Зародившись в начале XX века, идея технологизации образовательного процесса должна была выполнить ряд задач, связанных с оптимизацией учебновоспитательной деятельности.

Во второй половине XX в. зародился новый вид технологий - социальные технологии, способные оказывать прямое воздействие на общество, формировать политическую и общественную позицию, детерминировать дальнейшее социальное развитие. Распространение социальных технологий объясняют увеличением и глобализацией социальных контактов, интенсификацией информационного обмена, возникновением потребности в активных и творческих людях. 


\section{ТРАДИЦИИ И ИННОВАЦИИ В СОВРЕМЕННОЙ НАУКЕ И ОБРАЗОВАНИИ: ТЕОРИЯ И ПЕРЕДОВАЯ ПРАКТИКА}

Современная педагогическая практика пришла к выводу, что на этапе формирования базовых знаний требует обучение, сопровождающееся с технологизацией учебного процесса, делает его более управляемым и эффективным.

В связи с возникновением новых технологически оснащенных методов обучения иностранному языку возник вопрос о целесообразности функционирования традиционных методов обучения. Необходимость актуализации учебного процесса не означает полный отказ от традиционных методов в обучении, которые продуктивны для решения различных педагогических задач. Это особенно важно понимать современному молодому учителю, пытающемуся гармонично синтезировать традиционные методики обучения иностранному языку с интерактивными, и не делать уклон на одну принятую методику преподавания.

Технологический подход в обучении оформился в российской педагогике не как противостояние традиционному, а развивался на его основе, став преемником всего лучшего, чего достигла традиционная педагогическая теория и практика.

Таким образом, понятие «технология» сегодня относится ко всем дисциплинам в школе и высших учебных заведениях. Именно с помощью технологий входит в мировое пространство новая система образования. В переводе с греческого «технология» означает «совокупность способов переработки материалов, изготовления изделий и процессы, которые сопровождают эти виды работ. Понятие «технология» состоит из двух слов «техно» и «логия». «Техно» означает «мастерство», а «логия» - «учение», «слово». Итак, исходя из этого, «технология» - «учение о мастерстве».

Можно отметить, что термин «педагогическая технология», точнее «технологии в образовании», упоминается еще в 1920-е гг. в СССР. А.С. Макаренко впервые употребил его в связи с педагогической деятельностью. В настоящее время в язык педагогов прочно вошло понятие «педагогическая технология».

Таким образом, под образовательной технологией мы понимаем разработанную систему со-деятельности ученика и учителя по моделированию, организации и корректированию хода педагогической деятельности с целью достижения продуктивности обучения с условием создания психологически комфортной среды для всех участников образовательного процесса. 


\section{ТРАДИЦИИ И ИННОВАЦИИ В СОВРЕМЕННОЙ НАУКЕ И ОБРАЗОВАНИИ: ТЕОРИЯ И ПЕРЕДОВАЯ ПРАКТИКА}

Технология, как правило, реализуется в интерактивном режиме - в диалоговых формах образовательной деятельности учащихся. Поэтому важно освоение основ корпоративной культуры (в паре, группе). Технология всегда решает проблему, а потому главный принцип её содержания и реализации проблематизация обучения.

Педагогическая технология предполагает положительное влияние на ребенка для достижения продуктивности его развития. $\mathrm{K}$ основным характеристикам образовательной технологии относят: наличие гарантированности результатов обучения, структурирование и моделирование форм образовательного процесса, взаимодействующий характер содеятельности педагога и учеников, актуальность и преемственность приемов и методов обучения, динамичность учебно-воспитательной деятельности, создание комфортной учебной среды.

Анализируя конкретный блок преподаваемой дисциплины, педагог разрабатывает технологию обучения, видимую им как наиболее эффективную для достижения конкретных педагогических целей. При этом прогнозируемый педагогом продукт обучения должен быть достигнут посредством реализации целевых установок и цепочки взаимосвязанных и последовательных действий.

Педагогическая технология представляет собой совместную деятельность педагога и школьников, реализует принципы дифференциации и индивидуализации. В основе технологии лежат различные способы коммуникации, однако, несмотря на это она обладает универсальным характером и может применяться к любым школьным предметам. Это связано с тем, что педагогическая технология обладает одинаковыми этапами и элементами, а достижение результатов обучение прогнозируется на всех обучающихся вне зависимости от предмета обучения. В процессе учебной деятельности педагогическая технология подвергается диагностированию, измерению критериев и показателей успешности для достижения обозначенных результатов деятельности обучающихся.

В соответствии с выше сказанным, педагогическая технология представляет собой систему, состоящую из следующих элементов: цели, требования, средства и методы образования, характеристики прогнозируемых продуктов обучения; средства диагностики на каждом этапе технологии; системы со-деятельности «учитель-ученик»; критерии презентации результатов совместной работы. 


\section{ТРАДИЦИИ И ИННОВАЦИИ В СОВРЕМЕННОЙ НАУКЕ И ОБРАЗОВАНИИ: ТЕОРИЯ И ПЕРЕДОВАЯ ПРАКТИКА}

Технологии являются обусловленными реальностью процессами развития образования. Можно утверждать, что педагогическая технология - это системное, концептуальное, нормативное, вариативное описание деятельности учителя и ученика, направленное на достижение общеобразовательной цели.

Современное общественное развитие определяет маршрут развития педагогической технологии. Гуманизация и демократизация социума, взаимодействие педагогического опыта прошлого и общественного прогресса наполнили современную педагогическую технологию новым содержанием, имеющим в основе социальные реформы, новое гуманистическое педагогическое мышление, аккумуляцию российского и зарубежного педагогического опыта.

Поскольку содержание педагогической технологии детерминирует социальный заказ, она не является застывшим продуктом, а адаптируется к использованию в конкретной педагогической ситуации. Эффективность применения педагогической технологии, её структурные и содержательные инновации зависят от ценностной ориентации учебного заведения и уровня квалификации педагогов.

Федеральный государственный образовательный стандарт пропагандирует системно-деятельностный подход к процессу обучения, поскольку развитие личности может осуществляться только в результате активной деятельности обучающегося. В связи с чем, актуальными становятся методы обучения, способствующие развитию умений анализировать, логически мыслить, делать умозаключения, творить.

Приоритетными сегодня являются интерактивные технологии.

«Интерактив» в переводе с английского «inter» - взаимный, «act»действовать. Итак, интерактивный - способен к взаимодействию. По заключению учёных, сущность интерактивной методики состоит в том, что обучение основывается на постоянном активном взаимодействии всех участников процесса. Происходит непрерывное сотрудничество в схемах «учитель-ученик» и «ученик-ученик», при этом и педагог, и ребёнок являются равноправными субъектами учебного процесса [4].

По мнению М.А. Мудрак, назначение интеракций - стимуляция естественной активности обучающихся: умственной (интенсивность мышления, генерирования идей, высказывания предположений, проектирования, моделирования, конструирования, исследования и т.д., творческое 
воображение, сосредоточенность, внимание, наблюдательность, аналитикосинтезирующие операции); эмоциональной (эмоциональное напряжение, переживания), социальной (имитация выполнения социальных ролей, обмен мнениями, отношения, суждения и т.п.); физической (напряжение, практическая деятельность, подвижность).

При этом исследовательница дала определение, что активность понимается как энергичная, усиленная (интенсивная) деятельность, деятельностное участие, деятельностное состояние [3].

Именно сочетание всех видов природной активности ведёт к улучшению результатов при изучении нового материала на уроке.

Интерактивные технологии - это живая нить, связывающая учителя с каждым учеником и учеников между собой. С помощью интерактивных технологий у каждого субъекта учебного процесса есть равная возможность проявить свои знания, умения и навыки. Ещё Конфуций утверждал: «То, что я слышу - я забываю! То, что я вижу - я запоминаю! То, что я делаю - я понимаю».

История образования свидетельствует, что уже были попытки использования методик, которые основывались на принципах взаимного обучения. Так в 20-е годы XX века в глобальном реформировании образования в образовательных учреждениях практиковали такие методики, как «бригаднолабораторный» и «проектный» методы, а также применяли экскурсии как метод, работу в парах сменного состава и практику на производстве. В то время это было новым в образовании. Со временем элементами интерактивного обучения занимался В. Сухомлинский, В. Шаталов, Ш. Амонашвили - это начинающие развивающего обучения. Однако так складывалось, что развивающее обучение было в то время скорее исключением, чем правилом отечественного образования. Но в мировом образовании развивающие (интерактивные) методы обучения применялись достаточно широко.

Социальная потребность России - это люди, способные к самообразованию, самосовершенствованию, что нашло отражение и в докладе ЮНЕСКО «Образование: скрытое сокровище», где провозглашено: человек должен научиться: узнавать, то есть овладевать инструментарием, необходимым для понимания того, что происходит в мире; действовать таким образом, чтобы делать нужные изменения в среде своего обитания; жить в обществе, участвуя во всех видах человеческой деятельности [2]. 
Реализация этих задач возможна при условии постоянного развивающего обучения. Поэтому мы должны осуществить кардинальный переход от традиционного информационно-объяснительного обучения, ориентированного на передачу готовых знаний, к личностно-развивающему, направленному не только на усвоение знаний, но и на развитие личности учащихся (интерактивное обучение) [5].

Образовательный потенциал интерактивных технологий заключается в том, что они используются с целью: создания психологически подходящих условий обучения, при которых ученик чувствует свой индивидуальный прогресс, интеллектуальный рост; обеспечения возможности индивидуального восприятия учебной информации; создания условий для интенсивного обдумывания личного опыта и его соотнесения с опытом других; привлечения учащихся к активному осознанию новой информации, развитию навыков рефлексии; формирование коммуникативных навыков, критического мышления и самостоятельного поведения [7].

К главным характеристика интерактивного обучения можно отнести: образовательный процесс при постоянном активном взаимодействии всех обучающихся; это сообучение, взаимообучение (коллективное, групповое, обучение в сотрудничестве), когда ученик и учитель являются равноправными, равнозначными субъектами процесса обучения.

В основе интерактивного обучения лежит воспроизведение жизненных ситуаций, включение в образовательный процесс ролевых игр, общее решение учебных проблем посредством анализа учебной ситуации. Интерактивное обучение иностранному языку эффективно способствует формированию навыков и умений в общении на языке, выработке ценностей и моральных ориентиров, созданию атмосферы сотрудничества, со-деятельности.

Принимая во внимание изложенное, можно сделать вывод, что:

1. В основе интерактивных технологий лежит активная поисковая деятельность учащихся, в некоторых случаях требующая разъяснений педагога. Обучение с использованием интерактивных технологий предполагает активную самостоятельность школьников.

2. Образовательный процесс подразумевает гармоничное взаимодействие основных форм обучения: пассивной, наименее сложной, при которой ученик должен запомнить и воспроизвести информацию, активной, подразумевающей взаимодействие учителя и ученика, выполнение креативных заданий, и 
интерактивной, наиболее сложной, включающей активное взаимодействие, сотворчество.

При обучении иностранному языку на начальной и средней ступени обучения актуально применение педагогической игры. Поэтому для педагогики важно проанализировать понятие игровых технологий в дидактическом аспекте. Под игровыми педагогическими технологиями понимают различные методы и способы организации образовательного процесса в виде педагогических игр. Педагогическая игра имеет обучающую цель и задачи и прогнозируемый продукт учебно-познавательной деятельности, получаемый на выходе.

Советский психолог Л.С. Выготский указывал на неоспоримую важность игры в период взросления человека, поскольку путем замещения реального мира на мир игры ребенок учится имитировать разные социальные роли, находит себя в разнообразных проблемных ситуациях, учится решать типовые социальные задачи, применяя игру как площадку для формирования собственной поведенческой модели, реализуемой в многообразных социальных ситуациях.

Вопросам исследования и применения игр в образовательной деятельности посвятили свои исследования такие учёные, как Ш.А. Амонашвили, Н.К. Ахматов, В.Г. Семенов и др. В их научных трудах особая роль уделяется анализу дидактической игры, которая рассматривается ими с разных ракурсов: как форма обучения - В. Шаталов, как средство активизации учебно-воспитательного процесса - В. Онищук, однако все авторы сходятся во мнении, что игра обязательна в учебном процессе, она способствует более прочному усвоению знаний, формированию интереса к учебной деятельности, развитию творческих способностей школьников.

Дидактическая значимость игры очевидна: игра создает оптимистический настрой на познавательную деятельность, способствует формированию положительного отношения к учебной деятельности школьника, формирует умения и навыки непринужденно и легко. Игра лишена чрезмерной назидательности, что позволяет применять игровые технологии на уроках иностранного языка в начальной и средней школе.

Игра является ведущим средством воспитания подрастающего поколения. По мнению Л.И. Божович, игра является механизмом, который адаптирует требования социальной среды в потребности самого ребёнка [6]. 
Игровая учебная деятельность моделирует различные социальнокоммуникативные ситуации, определяет задачи и условия общения, речевые характеристики, интонационные образцы, способствует воссозданию аутентичной среды. Игровая организация работы над языком формирует положительное отношение к предмету обучения, мотивирует школьников и пробуждает в них познавательную активность.

В средней школе, обучая иностранному языку, требуется акцентировать внимание на теоретическом материале, используя в его изложении интерактивные методы, позволяющие школьникам проявлять учебную самостоятельность и активность, работая в группах по проектной методике. Задача педагога при таком подходе заключается в подготовке и организации самостоятельной работы обучающихся, при этом сам педагог корректирует и согласовывает работу учащихся.

Игровые технологии, как вид интерактивных технологий, способствуют повышению интереса школьников, поддержанию учебной мотивации, формированию языковых умений и навыков, совершенствованию мыслительных процессов, креативному подходу к овладению языком.

По нашему мнению, использование просто игры существенно отличается от игровых технологий, поскольку технология включает в себя целый комплекс методов, приёмов, принципов использования игр в учебно-воспитательном процессе. Поэтому использовать игровые технологии в процессе обучения иностранному языку в средней общеобразовательной школе в условиях реализации требований ФГОС среднего общего образования целесообразно.

Специфика предмета иностранного языка предполагает такую организацию учебного процесса, при которой каждый его участник имеет возможность активизировать познавательную и речевую деятельность и получить языковую практику, достаточную для формирования необходимых ему умений и навыков, в том числе путем использования интерактивных технологий обучения, которые, в свою очередь, дают участникам возможность принимать участие в «живом» интерактивном диалоге с реальным партнером, а также обеспечивают активный обмен мыслями между пользователем и информационной системой в режиме реального времени. 


\section{Список литературы}

1. Алимкулова М.К. Возможности расширения диалогического обучения на уроках английского языка через интерактивные формы работы // Молодой ученый. 2016. № 26.1 (130.1). С. 9-11.

2. Галустов А.Р. Проблема самообразования в отечественных и зарубежных педагогических исследованиях // Культурная жизнь Юга России. 2011. №3. C. 11-14.

3. Мудрак М.А. Интерактивные технологии обучения как средство формирования творческих способностей студента. URL: elibrary.kubg.edu.ua/ 508/1/Pavlyuk_R_NMIV_FLMD_PI.pdf).

4. Рахметова А.Т. Использование интерактивных методов обучения на занятиях по русскому и иностранному языку как средство активизации познавательной деятельности студентов // СНВ. 2015. №1 (10). С. 107-110

5. Федеральные государственные образовательные стандарты общего образования. URL: https://xn--80abucjiibhv9a.xn--p1ai/\%D0\%B4\%D0\%BE\%D0\% BA\%D1\%83\%D0\%BC\%D0\%B5\%D0\%BD\%D1\%82\%D1\%8B/543).

6. Храмцова Г.Г. Возможности использования игр и игровых упражнений в коррекции познавательных процессов младших школьников с нарушением интеллекта // Молодой ученый. - 2014. - №10. - С. 444).

7. Brown D.H. Teaching by principles: an interactive approach to language pedagogy. White Plains, NY: Longman, 2001. 480 p. 
УДК 34.01.

\title{
К ВОПРОСУ О ВИЗУАЛЬНОЙ ФОРМЕ ОБУЧАЮЩИХ МАТЕРИАЛОВ ДЛЯ СТУДЕНТОВ СПЕЦИАЛЬНОСТИ ЮРИСПРУДЕНЦИЯ НАЧАЛЬНЫХ КУРСОВ
}

Зарецкий Андрей Михайлович преподаватель, научный консультант ПСФ «Стальконструкция»

Аннотация: В последние годы все чаще раздаются голоса в пользу отхода от традиционных методов обучения при преподавании юридических дисциплин. Автором проведен анализ наиболее часто используемых интерактивных методов обучения, включающих в себя анализ проблемных ситуаций, мозговой штурм, аудиовизуальное обучение, т.п. Однако, как показывает практика, в Российской Федерации такой инструмент, как образовательный комикс, не нашел широкого распространения в силу того, что в большинстве юридических вузов преобладает традиционное обучение, основанное на пассивной роли студента в процессе получения знаний. Автор рассматривает историю появления комиксов и их внедрения в образовательный процесс, их особенности и возможности применения на примере школы и вуза и настаивает на необходимости введения данного инструмента в практику преподавания юридических дисциплин, особенно для студентов начальных курсов.

Ключевые слова: юридическое образование, образовательный комикс, визуальная форма обучения, методика преподавания, медиакоммуникация, теория государства и права.

\section{CONCERNING THE QUESTION ABOUT THE VISUAL FORM OF TRAINING MATERIALS FOR STUDENTS SPECIALTIES JURISPRUDENCE INITIAL COURSES}

\section{Zaretsky Andrey Mikhailovich}

\begin{abstract}
In recent years, voices have been increasingly voiced in favor of a departure from traditional teaching methods in teaching legal disciplines. The author analyzed the most frequently used interactive teaching methods, including the
\end{abstract}


analysis of problem situations, brainstorming, audiovisual training, etc. However, as practice shows, in the Russian Federation, such a tool as an educational comic strip is not widely used due to the fact that in most law schools traditional teaching based on the passive role of the student in the process of acquiring knowledge prevails. The author examines the history of the emergence of comics and their introduction into the educational process, their features and possibilities of application on the example of schools and universities and insists on the need to introduce this tool into the practice of teaching legal disciplines, especially for primary students.

Key words: legal education, educational comics, visual form of teaching, teaching methods, media communication, theory State and Low.

Особенности преподавания юридических дисциплин. Существующие изменения в социально-экономическом, политическом и прочих аспектах жизни общества и государства поставили перед необходимостью внести изменения в методы преподавания юридических дисциплин. В связи с тем, что гуманистические ценности получают все большее распространение в обществе, усиливается внимание к совершенствованию методики образования, отражающей уровень понимания научной и социальной природы окружающего мира и играющей важную роль в повышении эффективности преподавания учебных дисциплин, научное обоснование качественной методики преподавания юридических дисциплин является важным компонентом современного юридического образования.[1]

Подобная методика должна способствовать повышению качества образовательной деятельности, уровня профессиональной подготовки студентов и их интереса к приобретаемой профессии. К наиболее значимым компонентам методики преподавания юридических дисциплин относятся:

- рационализация и структурирование предмета, постановка целей и задач преподавания;

- определение методов и приемов обучения, средств оценивания;

- планирование учебной деятельности.

Юридическое образование позволяет обогатить интеллектуальный и творческий потенциал населения, повышает его культурный уровень, обеспечивает аппарата управления, правотворческих органов, правоохранительной системы, народного хозяйства квалифицированными специалистами в области права. Главная цель профессионального 
юридического образования состоит в формировании мировоззренческой позиции юриста, которая основывается на восприятии, осознании и осмыслении всего богатства юридической мысли и накопленного правового опыта. [2,c.140]

Методом обучения называется процесс взаимодействия между преподавателем и студентами, в результате чего последние получают и усваивают знания, умения и навыки, предусмотренные содержанием обучения. Современная педагогика делит существующие методы обучения на пассивные или традиционные, активные и интерактивные, выделяя в качестве основания для классификации уровень вовлеченности учащихся в учебную деятельность, что рассматривается как один из основных критериев эффективности образования.

Традиционные методы в преподавании правовых дисциплин в виде лекции, демонстрации, иллюстрации, объяснения, рассказа и др. подразумевают одностороннее воздействие учителя на ученика, когда обучаемые являются пассивными участниками или объектами образовательного процесса. Суть традиционной организации учебного процесса означает трансляцию преподавателем информации с eе последующим воспроизведением обучающимся, который занимает лишь позицию воспринимающего. Пассивные методы за короткий промежуток времени позволяют передать значительный объем учебной информации, преподаватель может контролировать объем и глубину изучения учебного материала, процесс обучения, влияет на результаты учебной деятельности. Чаще всего педагогической практике в целом и преподавании юридических дисциплин, в частности, используется лекция, которая может быть вводной, текущей, обзорной, обобщающей, проблемной, иллюстративной, т.д., в зависимости от поставленных преподавателем задач.

Подобная форма преподавания лишь в малой степени соответствует принципам компетентностного подхода, предполагающего подготовку специалиста с необходимыми для практической деятельности компетенциями в различных сферах юриспруденции: нормотворческой, правоприменительной, правоохранительной, научно- педагогической. Учебные образовательные программы требуют согласования с будущими работодателями, для которых вуз обучает студентов, т. е. работодатель должен непосредственно принимать участие в формировании каталога элективных дисциплин. Необходимо 
отметить, что одним из важных моментов в повышении качества подготовки юристов является более широкое внедрение учебных курсов по выбору студентов. Выбор основывается на результатах собственных научных исследований преподавателей, принимающих во внимание качество и степень востребованности содержания дисциплин. При условии систематического обновления каталога элективных дисциплин будет постоянно вестись научный поиск, будут улучшаться навыки классификации и изложения результатов исследований, что в конечном итоге расширит научную эрудицию профессорско- преподавательского состава, даст возможность излагать основы фундаментальных знаний, делая их интересными для широкого круга студентов. Для создания таких курсов преподаватели занимаются научными исследованиями в области правовых проблем, проводят научные исследования, передавая результаты студентам. Сегодняшнему выпускнику вуза нужно не просто обладать юридическими знаниями, но также быть готовым применить их на практике в соответствующей организации. Иными словами, оценка работы вуза главным объектом процесса «оценивания» делает выпускника с его востребованностью на рынке труда, уровнем его знаний, степенью адаптации к рыночным условиям и готовностью к дальнейшему совершенствованию полученного образования.[2, с. 144].

Использование активных методов обучения, представленных диалогом, беседой и др., ослабляет центрическое воздействие преподавателя на аудиторию, улучшает их взаимодействие. Современное правовое образование особое внимание уделяет рассмотрению социальных проблем, дискуссионных вопросов, конфликту ценностей и способам принятия взвешенных ответственных решений. Рассмотрение сложных противоречивых общественных вопросов выступаем одним из основных приемов правового образования, поскольку право и политика ярче всего проявляются в проблемных ситуациях.

Интерактивное обучение означает такую форму совместной деятельности студентов, когда все участники вступают во взаимодействие друг с другом, обмениваясь информацией, совместно решая проблемы, моделируя ситуации, оценивая действия других и свое собственное поведение.

Благодаря внедрению Федеральных государственных образовательных стандартов Высшего профессионального образования (ФГОС ВПО) на основе компетентностного подхода, актуализировалась значимость применения 
образовательных технологий и интерактивных методов в процессе обучения. В 80-х годах XX в. Национальный тренинговый центр (США, Мэриленд) провел исследование, в результате которого были проранжированы методы обучения на основании уровня усвоения учебного материала. Согласно полученным результатам, наименьший процент усвоения учебного материала показали пассивные методы, а активные и интерактивные - самый высокий. Интерактивные форм и методы обучения позволяют приобрести студенту опыт освоения содержания будущей профессиональной деятельности во взаимосвязи с практикой, развить навыки общения и взаимодействия в малой группе, поощряют к гибкой смене социальных ролей в зависимости от ситуации, развивают навыки анализа и самоанализа в процессе групповой рефлексии, способность разрешать конфликты. [3]

В правовом образовании часто используется метод моделирования, представляющего собой построение и изучение моделей реально существующих объектов, процессов или явлений с целью получения объяснений этих явлений. Цель моделирования состоит в эффективном решении проблемных ситуаций.[4]

Кроме того, студенты-юристы часто сталкиваются в процессе обучения с таким методом обучения, как игра. У учебных игр присутствуют четко поставленные цели обучения и соответствующие ей педагогические результаты. Среди ее преимуществ следует назвать следующие:

- Создание интереса и мотивации учебной деятельности,

- Направленность на практическое применение имеющихся знаний и навыков

- Связь учебной деятельности с реальными жизненными проблемами

- Развитие интеллектуальных, коммуникативных и творческих способностей обучающихся, умения разрешать проблемы и принимать решения.

В правовом образовании чаще всего используются сюжетные, ролевые, деловые, имитационные, дидактические или образовательные игры, с присущими им характеристиками. Так, деловая игра представляет собой имитацию конкретной ситуации и имеет своей целью формирование профессиональных компетенций в условиях имитации реальных условий. Происходит отработка конкретных специфических операций, моделируется соответствующий рабочий процесс, студенты получают навыки принятия 
решений в правовой сфере деятельности. Ролевая игра направлена на решение проблемы путем исследования различных способов поведения в конкретных ситуациях, когда студенты вживаются в роли других людей и ведут себя в соответствии с ними. Ролевая игра предполагает незаконченные ситуации, в которых нужно принять конкретное решение и завершить предложенную ситуацию. В дидактических, интеллектуальных или познавательных играх имеются фиксированные правила. В дидактических играх учащиеся должны мобилизовать имеющиеся знания, принять решение, проявляя находчивость, чтобы в конечном результате выиграть состязание. Для таких целей лучше всего подходят учебный суд или метод упрощенного судебного разбирательства, моделирование которого в последние годы пользуется большой популярностью в общеобразовательных и высших школах. Учебный суд может быть основан на реальных или вымышленных событиях. Применение учебного суда на учебном занятии позволяет:

- получить представления о предназначении судебного процесса;

- понять фундаментальные основы легального механизма, используемого обществом для разрешения большинства конфликтов;

- развивает у учащихся коллективизм, умение работать в команде;

- лучше понимаются роли отдельных участников судебного процесса и другие цели.

«Мозговая атака» - брейнсторминг представляет собой метод, при котором принимается любой ответ обучающегося на заданный проблемный вопрос. Он используется для обсуждения спорных вопросов, сбора большого количества идей в течение короткого периода времени, выяснения информированности или подготовленности аудитории. В процесс участники свободно обмениваются идеями по мере их возникновения, так что каждый может развивать чужие идеи.

ПОПС-формула используется при организации споров, дискуссий в соответствии со следующей схемой. Обучающимся высказывается:

П - позиция (объясняет сущность свой точки зрения);

О - обоснование (приводит аргументы в ее пользу, доказывает ее);

П - пример (разъясняя суть своей позиции, приводит конкретные примеры);

С - следствие (приходит к определенным выводам в результате обсуждения). 
ПОПС-формула может применяться для опроса по пройденной теме, при закреплении изученного материала, проверке домашнего задания.

Кейс-метод (разбор конкретных ситуаций), который насчитывает около 30 модификаций, включая кейс-метод (Case-study). Эта техника обучения использует описание реальных ситуаций, когда студентов просят провести анализ ситуации, разобраться в сути проблем, предложить возможные варианты решения и выбрать лучший из них. Для данного метода характерна активизация обучающихся, подчеркивание достижений и успехов участников. Ощущение успеха выступает как одна из движущих сил метода, способствуя формированию устойчивой позитивной мотивации и наращивая познавательную активность.

Тренинг представляет собой процесс получения навыков и умений в какой-либо области через выполнение последовательных заданий, действий для достижения наработки и развития требуемого навыка.

Одной из наиболее актуальных задач правового образования является умение вести правовую переписку, работать с печатными, аудиовизуальными и визуальными материалами, связанными с юриспруденцией. Такие материалы являются важным альтернативным источником знания, дополняющим учебную литературу. Их преимущество состоит в том, что они помогают мотивировать, стимулируют и активизируют учебную деятельность; повышают интенсивность процесса обучения, активизируя ранее полученное знание; углубляют и расширяют процесс познания; способствуют развитию критического и аналитического мышления, наблюдательности.

Кстати, в последнее время примером успешного внедрения комиксов в юриспруденцию являются договора-комиксы, созданные юристом из ЮжноАфриканской Республики Робертом Де Ройем (Robert de Rooy). Первым в мире экземпляром стал трудовой договор со сборщиками фруктов в провинции Вестерн Кейп. (рис. 1) 


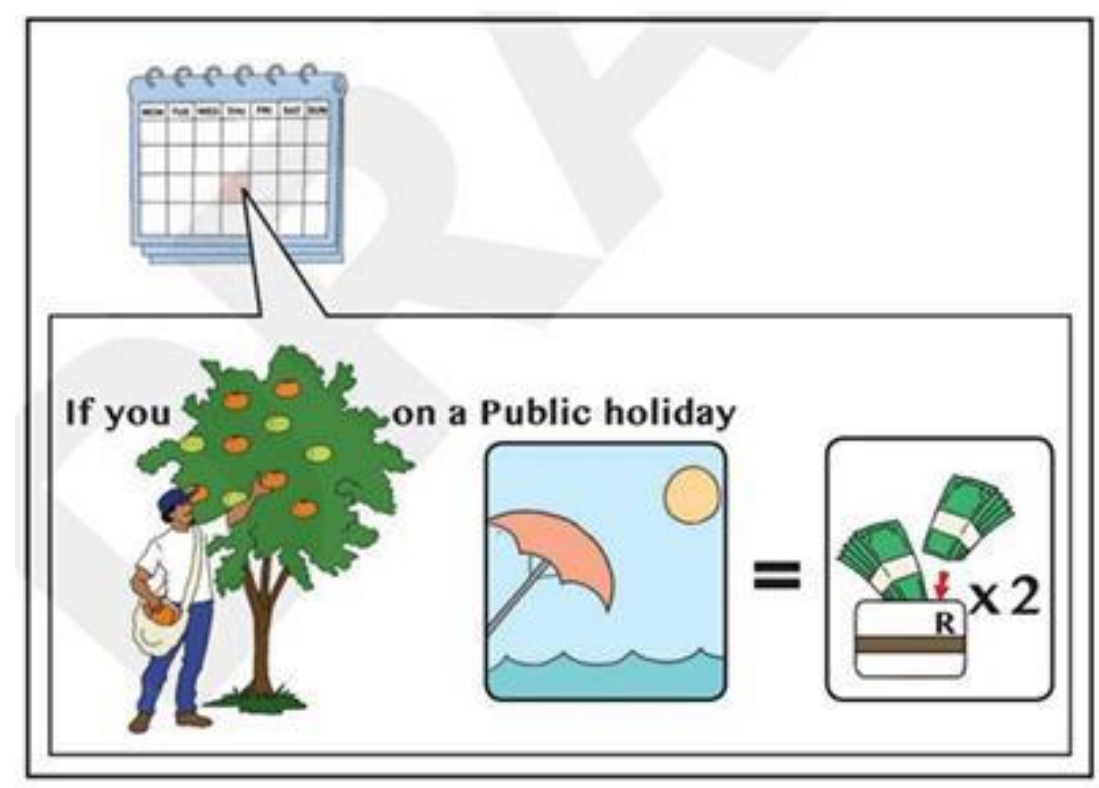

Рис. 1. Пример договора в комиксах

Его идея была высоко оценена Глобальной ассоциацией управления договорами (IACCM), так что в 2016 году он получил награду за «видимые изменения». [5]

Сейчас Де Рой вступил в партнерство с Jincom, чтобы рисовать договорыкомиксы для других компаний, которым тоже понравилась эта идея. Они решили не ограничиваться только сельским хозяйством. Например, были сделаны или находятся в процессе подготовки договоры:

- работников кухни для сети отелей;

- правила поведения для фитнес-клубов в Австралии;

- соглашения для домашнего персонала;

- кредитные договоры;

- соглашения о похоронном страховании;

- аренда.

Среди других примеров можно назвать соглашение о неразглашении для крупной международной компании Unilever, взаимодействующей с различными поставщиками во многих странах. В 2018 году профессор Камилла Андерсен и ее команда из Университета Западной Австралии создали первый иллюстрированный договор в Австралии, который заказала международная консалтинговая фирма Aurecon.

Аудиовизуальный метод обучения. Метод предназначен для популяризации знаний и привлечения к обучению широкой аудитории, стал все 
чаще применяться в университетском образовании многих стран мира и реализован в таких формах, как аудиовизуальные курсы, электронные учебники, компьютерные тестовые задания, тренинги и практические пособия для индивидуального и дистанционного обучения, видеозаписи с целью анализа и обсуждения действий участников учебного процесса. Широко внедряя технические средства обучения в профессиональную подготовку юристов, используя возможности Интернет, работа преподавателей позволяет усиливать познавательную активность студентов, достичь существенной экономии времени для усвоения учебного материала в значительных объемах. Метод характеризуется минимальными затратами учебного времени и экономией усилий студентов и преподавателей во время аудиторного занятия. Например, использование мультимедийного оборудования и проверка знаний студентов посредством компьютерной техники значительно улучшает количественные и качественные показатели обучения. Для реализации возможностей аудиовизуального метода привлекается все больше профессионалов из технической и других смежных сфер. В настоящее время данный метод широко используется для обучения иностранным языкам студентов-юристов. Этот метод очень требователен к уровню подготовки преподавателя в плане владения компьютерными знаниями и технологиями, наличия системного и творческого видения предмета.

Подводя итоги вышесказанному, необходимо подчеркнуть, что интерактивные методы позволяют создавать учебную среду для одновременного усвоения теории и практики, давая возможность обучающимся развивать юридическое мировоззрение, логическое и критическое мышление, профессиональную грамотную речь; выявлять и реализовать индивидуальные возможности. В ходе учебно-воспитательного процесса обучающиеся сами ищут связь между новыми и уже полученными знаниями, учатся принимать альтернативные решения, формировать свои собственные идеи и мысли с помощью различных средств, сотрудничать.

О необходимости внесения изменений в образовательный процесс. Современная методическая литература отмечает, что в вузовском преподавании главной трудностью являются сложившиеся и укоренившиеся в образовательной практике стереотипы преподавания. Большинство начинающих свою деятельность в вузе преподавателей не руководствуется современными достижениями наук об образовании, предпочитая просто 
воспроизводить те подходы, посредством которых учили их самих. Их методический арсенал ограничен набором однообразных форм и методов работы, состоящим из неизменных «информационных» лекций, семинаров, экзаменационных билетов.[6]

В условиях, когда нарастают глобализационные и информационные вызовы, включение в российское юридическое образование интерактивных методов обучения становится неизбежным. Кроме того, переход на болонскую систему привел к уменьшению количества часов аудиторных занятий для студентов бакалавриата, что требует поиска оптимальных методов обучения в таких условиях. Самым сложным в этом отношении является вопрос об определении верного для каждой отдельно взятой категории студентов соотношения традиционных и инновационных методов.[7]

Одним из нетрадиционных методов обучения является использование образовательных комиксов в практике преподавания юридических дисциплин. Специфика образовательного процесса в юриспруденции заключается в жесткой регламентации изучаемых понятий и процедур, реализуемых в практической деятельности представителей юридических профессий - судей, прокуроров, адвокатов, следователей, пр., в связи с чем возникает вопрос насколько эффективно применение метода образовательных комиксов в такой сфере, как юриспруденция?

Прежде чем ответить на данный вопрос, необходимо вернуться к такому понятию, как содержание и структура методики преподавания юридических дисциплин.

В структуре методики преподавания юридических дисциплин выделяют три самостоятельных, но взаимосвязанных структурных элемента:

1) исследовательский, задачами которого являются 1) выявление и формулирование закономерностей образовательного процесса, включая обучение и воспитание; 2) обоснование наиболее эффективных регулятивов построения образовательного процесса; 3) выявление закономерностей включения и приобщения обучаемого к сфере научных знаний; 4) определение закономерностей развития у обучаемого соответствующих профессии навыков, умений и формирования соответствующих компетенций; 5) раскрытие закономерностей развития у студентов черт социально зрелой и социально надёжной личности.

2) прикладной, суть которого составляют: 1) осмысление и формулирование эффективной модели образовательного процесса; 2) 
обосновании процедуры поиска и отбора «учебного материла» из теоретических исследований и реальной юридической практики; 3) выработка наиболее эффективных форм, способов и приёмов преподнесения конкретного для данной учебной дисциплины учебного материала обучаемым и включения их в освоение преподносимого им учебного материала; 4) разработка соответствующих профессиональной подготовке преподавателя его уровню методической и педагогической культуры методических регулятивов; 5) обоснование алгоритма использования методических регулятивов при проведении конкретных видов учебных занятий; 6) выработка механизма контроля за процессом развития у обучаемых необходимых навыков, умений и компетенций; 7) создание вариантов механизмов обратной связи между преподавателем и студентом в образовательном процессе с целью его совершенствования.

3) Самообразовательныц̆, который направлен на: 1) выработку и обоснование методических регулятивов для самосовершенствования методической культуры преподавателя; 2) выявление возможностей и путей совершенствования методики преподавания конкретной учебной дисциплины; 3) поиск вариантов комплексирования методик преподавания различных учебных дисциплин.

Таким образом, в образовательном процессе от методики преподавания юридических дисциплин ожидается обеспечение реализации связи теории с практикой, систематичность и последовательность в овладении учебным материалом; повышается сознательность, активность и самостоятельность студентов в учебе; индивидуальный поиск знаний объединяется с учебной работой в коллективе.

Психологические основы методики преподавания имеют важное значение, и к относятся создание оптимальной социально-психологической атмосферы в аудитории, установление контакта с обучаемыми, использование приёмов и форм активизации познавательной, мыслительной деятельности студентов, поддержания активного состояния обучаемых на протяжении всего занятия. Одной из главных выступает задача по установлению контакта с аудиторией, отправка прямой и получение обратной связи от нее.

Важным психологическим инструментом, позволяющим включить студентов в активный режим освоения лекционного материала, являются современные мультимедиа технологии мультимедиа, благодаря которым можно 
строить информативные схемы и графики, иллюстрировать лекционные положения с помощью фото, звукового ряда и видеоклипов.[8] Наглядность выступает ключевым аргументом использования мультимедийных средств. Как показали опросы, большинство студентов считает, что наглядность делает восприятие материала более доступным для понимания и запоминания. В этой связи применение комиксов, особенно создаваемых самими студентами как самостоятельный творческий проект, придает даже лекционным занятиям большую доступность и повышает их эффективность.

Лекция как метод обучения ответственна за обеспечение теоретической основы обучения, развитие интереса к учебной деятельности и конкретной учебной дисциплине, формирование у обучающихся ориентиров для самостоятельной работы над курсом. Методически «правильная» лекция соответствует современному уровню развития науки и техники; имеет законченный вид освещения учебной темы; обладает внутренней убежденностью, силой логической аргументации, вызывает у студентов познавательный интерес. Всему вышеперечисленному содействует не только формальное содержание лекции, но и способы, посредством которых оно доносится до аудитории, например, визуальный метод, разновидностью которого является метод образовательных комиксов.

К примеру, одним из базовых и крайне важных для студентов-юристов предметов на начальных курсах является «Теория государства и права». ТГП является фундаментальной юридической наукой, изучающей сущность, наиболее общие закономерности и тенденции происхождения, развития и функционирования государства и права в их постоянном взаимодействии, формирует общие для всех юридических наук понятия и категории. Без усвоения такого начального багажа знаний разобраться в более конкретизированных, эмпиричных знаниях о государстве и праве, используемых основными юридическими науками становится крайне сложным.

На наш взгляд, использование образовательных комиксов можно отнести к методам, стимулирующим мотивацию к обучению. Для лучшего усвоения материала необходимо, чтобы он вызывал у студентов интерес, с одной стороны, а с другой - необходимо поощрять их познавательный интерес, с чем хорошо справляются наглядные методики. Как отмечает В.А. Лысаков, в качестве предпосылок внедрения в образовательную практику интерактивных методов обучения правовым дисциплинам на сегодняшний день можно выделить следующие факторы: 
- Психологические особенности современного

поколения обучающихся: демократичность, лёгкость освоения теле-видеокоммуникационных технических средств, ресурсов сети Интернет, общительность, преобладание визуального способа восприятия информации, а также - инфантильность, малый опыт правовых отношений.

- Бурное развитие информационных технологий. После появления в Российской Федерации структур информационного общества («электронное государство», «электронное правительство», «электронное правосудие») последовали государственные автоматизированные информационные системы (ГАС РФ «Выборы», ГАС РФ «Правосудие», ЕАИКС - Единая автоматизированная информационно-коммуникационная система арбитражных судов РФ). Подобная динамика изменений в российском законодательстве ставит студентов перед необходимостью учиться навыкам самостоятельного поиска информации с использованием справочных поисковых систем Консультант Плюс, Гарант.

- Необходимость реализации компетентностного подхода, предусмотренного ФГОС, которые предполагают применение в учебном процессе нетрадиционных активных и интерактивных методов, инновационных технологий.[9]

Что такое «Образовательные комиксы» и в чем их особенности. Термин «образовательные комиксы» (англ. Educational comics) означает разновидность адаптированной литературы, распространённой в США, Великобритании, на территории Южной Кореи и Японии.

Своим появлением образовательные комиксы обязаны Родольфу Тёпферу, который, как считается, создал первый комикс в 1845 г. По мнению критика и историка комиксов Карла Мэйсека, образовательные комиксы были известны еще в далекие 1930-е годы, и уже с тех пор ведется полемика о пользе комиксов как средства обучения. Профессор Питтсбургского университета У.Д. Соунс подсчитал, что в 1935-1944 гг. в США вышло свыше ста публикаций в педагогической и образовательной периодике о потенциально возможном использовании комиксов для обучения детей.

Образовательные комиксы поныне продолжают оставаться средством народного образования в США, выступая уже не как второстепенная, вспомогательная литература, а основной источник учебной информации, заменив собою учебники по литературе и первоисточники - литературные оригиналы, на основе которых они были написаны. 
Уровень развития современных комиксов настолько высок, что многие школьники практически перестали обращаться к первоисточникам, сделав выбор в пользу их адаптированных, менее объёмных, иллюстрированных версий. То, что читатели больше предпочитают комиксы другим видам литературы, является характерной чертой всех возрастных групп американского общества, не только для детской аудитории.

Как показали исследования Джорджа Рейнольдса, некоторые дети, зачитывающиеся комиксами, даже не подозревали о существовании литературных подлинников, на основании которых эти комиксы были написаны.

Сам Рейнольдс давал крайне негативные отзывы об образовательной роли комиксов, утверждая, что они не воспитывают в детях ничего, кроме кровожадности. Мнение, что под влиянием комиксов дети полностью откажутся от чтения обычных книг, преобладало в американском обществе до 1950-х годов. Сторонники дальнейшего внедрения комиксов в образовательную программу, получавшие поддержку от компаний-производителей комиксов, твердо стояли на том, что чтение комиксов не наносит вреда нормально развивающемуся ребёнку со стабильной психикой и не оказывает отрицательного влияния на интеллектуальное развитие умственно отсталых детей. [10]

Примером русского комикса с содержанием юмористической составляющей можно считать русский лубок. Лубки в виде азбуки, календарей, травников представляют собой не просто картинки, а настоящую библиотеку народной грамотности. В 1937 году увидела свет детская книга-альбом «Рассказы в картинках» художника Николая Радлова.

Другим предшественником комиксов является карикатура, у которой комикс позаимствовал так называемый филактер (пузырь, облако), в который вынесена речь персонажей. Небольшие карикатурные истории в картинках, печатались в журнале для взрослых «Крокодил», а иностранные комиксы можно было встретить в научно-популярном журнале «Наука и жизнь». Детский юмористический журнал «Весёлые картинки» печатал истории в картинках для досуга всей семьи.

В середине 2010-х в России впервые произошел бум комиксов, когда рисованные истории были выпущены более чем десятком издательств. В 2012 году издан комикс «Иллюстрированная Конституция России», авторами 
которой являются Наталья Худякова и Максим Горелов, выходивший в России тремя тиражами с 2012 по 2014 годы.

Основой «Иллюстрированной Конституции России» является текст Конституции России на русском языке с учётом изменений, внесённых законами Федерации о поправках к Конституции Российской Федерации от 30 декабря 2008 г. № 6-ФКЗ, от 30 декабря 2008 г. № 7-ФКЗ и от 5 февраля 2014 года № 2-ФКЗ, а также его официальный перевод на английский язык. Русскоязычная часть книги была постатейно проиллюстрирована цветными изображениями и схемами, выполненными преимущественно в инфографике, элементы которой стилизованы под русский национальный стиль, англоязычная часть издания имеет текстовый вид.[11]

Несмотря на критику, второе издание «Иллюстрированной Конституции России» входило в число книг, указанных в «Методических рекомендациях по организации и проведению открытого урока в День знаний, посвященного 20летию Конституции РФ» в образовательных учреждениях Нижегородской области.

Исследователи отмечают, что комикс, являясь новым образовательным инструментом с новыми свойствами и новым воздействием на ребенка, повышает мотивацию к изучению, воспринимается легче и интереснее, обеспечивает визуальную поддержку обучению. Использование комиксов позволяет сократить по времени длительность презентации, доклада, лекции или объяснения нового понятия.

Вместе с тем нельзя отрицать вероятность, что ребенок может отвыкнуть от объемных текстов, негативно отнестись к адаптированным текстам или неверно истолковать юмористическую составляющую ситуации. [12]

В комиксах текст не всегда присутствует, существуют и «немые» комиксы с интуитивно понятным сюжетом.[13] Сегодня некоторые исследователи рассматривают комиксы (рисованные истории) как отдельный тип медиа и отмечают, что вхождение комиксов чем-то схоже с вхождением Интернета, когда «возникает совершенно новая коммуникативная среда, которая полностью отражает желания потребителя». По мнению Г. Почепцова, визуальность всегда связана с массовостью, будучи понятной и без знания языка. Яркими примерами такого массового воздействия являются кино и телевидение, одновременно сопровождаемые понижением возрастного и интеллектуального уровня потребителя. Г. Почепцов рассматривает комиксы 
как медиакоммуникации, опущенные из будущего в прошлое ввиду того, что они с ошеломительной скоростью захватили массовую аудиторию.

К основным характеристикам комиксов исследователи относят:

- соединение визуального и вербального;

- акцент на действиях, а не описании;

- действующие лица - супергерои;

- наличие в структуре разрывов и пропусков, которые должен заполнить читатель.

Комикс выступает как некая медиа-технология, несущая в себе новые способы упаковки смыслов и их доставки, и способная влиять на типы смыслов. Глобальные проблемы, которые не могли решить технологии коммуникации, от книг до кино и телевидения, не должны решаться последними. Их суть состоит в разной упаковке смыслов, в частности, комиксы интересны как объект семиотического исследования в силу объединения вербального и визуального. Комиксы относятся исследователями к последовательному искусству, поскольку изображения следуют друг за другом, создавая единую структуру. Другой особенностью комиксов является сочетание воображаемого и документального рисунков. Благодаря комиксам, человечество узнало про супергероев, поскольку последние практически вернули миру мифологическое сознание, реализуя потребность людей в мифах.

Применительно возможностей развития медиадидактики, Е. Нагорная предлагает наличие следующих показателей способностей ученика к восприятию комиксов:

- многоаспектность осознания и восприятия композиции отдельных кадров и их связей;

- определение логики развития авторской мысли в пространственновременных измерениях, выражающееся через изменение планов изображения, особый ритм повествования;

- чтение образности кадра, понимание приемов художественного решения;

- восприятие развития художественной мысли в комплексном единстве, проявляющееся через графическую организацию кадра, повтор визуальных образов, эмоционально-смысловое соотношение отдельных кадров.[14]

В школьном образовании необходимость использования комиксов объясняется следующими аспектами обучения: 


\section{ТРАДИЦИИ И ИННОВАЦИИ В СОВРЕМЕННОЙ НАУКЕ И ОБРАЗОВАНИИ: ТЕОРИЯ И ПЕРЕДОВАЯ ПРАКТИКА}

- Комиксы могут быть увлекательной альтернативой школьным сочинениям

- $\mathrm{C}$ помощью комиксов можно описать жизнь известной исторической личности, проиллюстрировав её фотографиями, рисунками, комментариями.

- При выполнении ученических проектов и их последующей защите многие ученики испытывают скуку, т.к. ощущают давящую серьезность и отсутствие возможности проявить свои творческие способности

- Составление текстов к комиксам позволяет детям самим готовить тексты к представленному учителем или подготовленными ими самими визуальным средствам в виде видео, картинок, схем.

- Иллюстрация норм и правил в виде комиксов запоминается быстрее и лучше, особенно, если дети готовят их сами.

- Понятийный словарик позволяет ученикам быстрее освоить терминологию по определенным предметам, если они сами готовят картинки и словесное сопровождение.

- Отчёт о проведённом мероприятии позволяет детям проявить в полной мере свои творческие способности и особенности видения различных ситуаций.

- Завершение комикса, когда его сюжет уже задан учителем, и ученикам нужно придумать окончание.

- Подготовка недостающих кадров, когда в комиксе удалены несколько кадров, а ученикам нужно восстановить их, продумав цепочку отношений в сюжете.[15]

Комиксы в вузовском образовании. Что касается особенностей использования комиксов в вузовском обучении, С. Макклауд отмечал, что комиксы обеспечивают повествовательный опыт для студентов, когда они следят за началом и концом истории, развитием сюжета, отношениями персонажей, временем и обстановкой, выстраивают последовательность. Изображения, поддерживая текст, дают учащимся важные контекстуальные подсказки к значению изучаемого материала и выступают в качестве подмостков для понимания студентов.

Stephen Cary в книге «Going Graphic: Comics at Work in the Multilingual Classroom» отмечает, что комиксы мотивируют неохотных читателей, вовлекая их в принадлежащий им литературный формат. Благодаря этому, они легче 
понимают материал. Как показали исследования, средняя продолжительность концентрации внимания современных студентов составляет около 20 минут, что явно недостаточно для передачи что-либо с помощью традиционных методов обучения.

Morrison T.G., Bryan G., Chilcoat G.W. полагают, что при проектировании своих собственных комиксов у студентов развиваются навыки понимания и исследования. Josh Elder, основатель и президент компании Reading With Pictures, описывает преимущества комиксов как образовательных инструментов:

- Комиксы передают смысл через активное взаимодействие читателя с письменным языком и сопоставленными последовательными изображениями. Благодаря этому, читатели активно извлекают смысл из взаимодействия текста и изображений.

- Комиксы способны передавать большое количество информации за короткое время, что особенно эффективно для преподавания содержания в области математики, естественных наук, обществознания.

- Коллективная обработка текста и изображений приводит к лучшему запоминанию и усвоению.

Современные педагоги много спорят по поводу использования комиксов в образовательном процессе. Если Америка, Канаде, частично - Европа и Япония активно пользуются комиксами как инструментом обучения, то в России противниками такого пути являются многие учителя и преподаватели.

По мнению автора, введение образовательных комиксов на начальном этапе обучения юридическим специальностям помогло бы значительно упростить и ускорить образовательный процесс, повысить его общую эффективность. К примеру, в традиционных учебниках различие между правом и законом обычно раскрывается так, что многие студенты не в состоянии уловить разницу в содержании определений. В предлагаемом автором учебном пособии по теории государства и права в виде иллюстраций с пояснениями значительно облегчается понимание материала. 


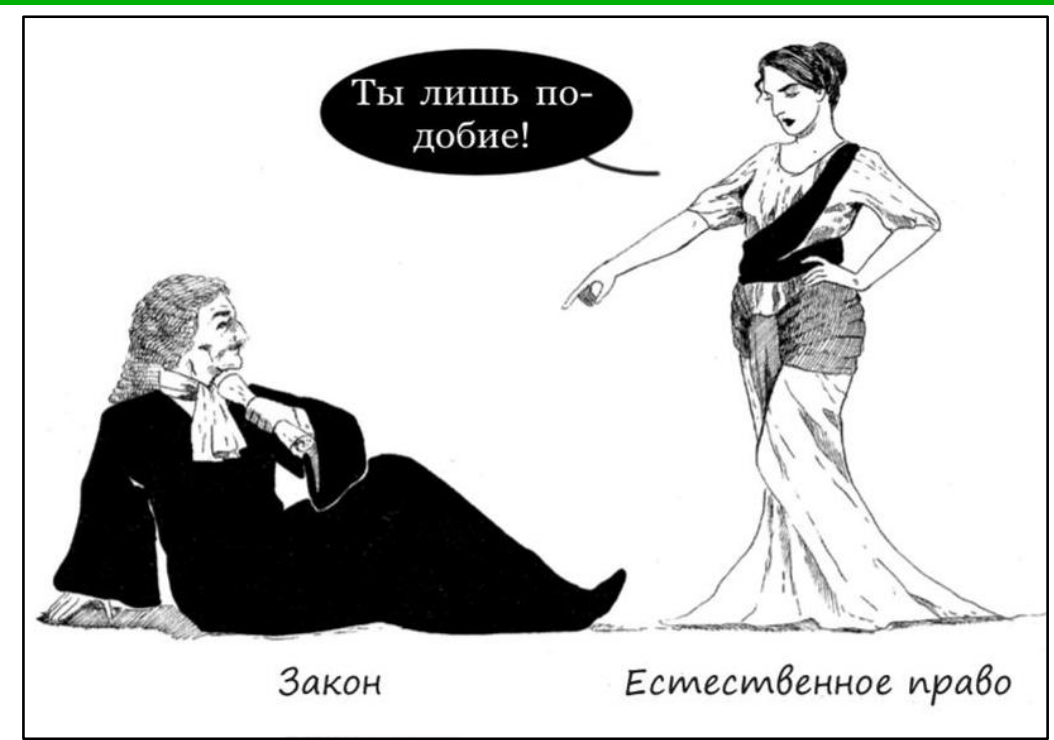

Рис. 2. Пример образовательного комикса в юриспруденции

В проведенном Т.И. Авдеевой и др. исследовании было показано, что участники, прочитавшие комикс, лучше прошли викторину, чем те, кто читал традиционный учебник. Свыше $80 \%$ студентов указали, что комиксы выгодно отличаются от традиционных учебников. Можно сказать, что студенты готовы к внедрению и использованию комиксов в образовательном процессе для повышения качества образования. Результаты исследования показывают, что нетрадиционные технологии могут быть использованы в качестве средства для привлечения студентов к учебной деятельности и для их мотивации и подготовки к реальной жизни. В частности, использование комиксов делает обучение интересным, а студенты извлекают пользу из знаний. В целом отношение студентов к использованию комиксов в образовательном процессе было благоприятным. Почти все студенты придерживались позитивных взглядов на ценность комиксов как педагогического подхода, который развивает критическое мышление.[16]

Главным недостатком следует назвать некоторую ограниченность данного исследования, поскольку сравнений с другими инструментами обучения не проводилось, что могло повлиять на взгляды студентов. Ценность для будущего обучения состоит в том, что комиксы отличаются привлекательностью как инновационный инструмент, обеспечивая отправную точку для профессионального развития студентов и полезный механизм для организации занятий оригинальным способом.

Таким образом, необходимость введения нового образовательного инструмента - учебного пособия в виде иллюстрированного комикса по 
дисциплине «Теория государства и права» объясняется рядом объективных факторов, среди которых следует назвать более доступный для усвоения формат подачи материала, сокращение временных затрат на усвоение основных понятий курса, стимулирование познавательного интереса к изучаемому курсу, повышение собственной активности студентов в свете необычной формы подачи новых знаний и способов формирования новых знаний и навыков, создание непринужденной атмосферы на занятиях для свободного обмена мнениями и обсуждения результатов академической беседы между студентами и преподавателями.

\section{Список литературы}

1. Петрова Е.В. К вопросу о методике преподавания юридических дисциплин. [Электронный pecypc] URL: https://cyberleninka.ru/article/n/kvoprosu-o-metodike-prepodavaniya-yuridicheskih-distsiplin/viewer

2. Зарецкий А.М. Введение в юридическую профессию / А.М. Зарецкий. М.: ЭДИТУС, 2020. -430 c.

3. Жадан В.И. Опыт применения интерактивных и инновационных методов и форм обучения в преподавании юридических дисциплин. [Электронный pecypc] URL: https://cyberleninka.ru/article/n/opyt-primeneniyainteraktivnyh-i-innovatsionnyh-form-i-metodov-obucheniya-v-prepodavaniiyuridicheskih-distsiplin

4. Васильев К. Особенности обучения по специальности юриспруденция. [Электронный ресурс] URL: https://disshelp.ru/blog/osobennostiobucheniya-po-spetsialnosti-yurisprudentsiya/

5. Нарисуй мне договор: кто и зачем придумал комиксы-контракты. [Электронный ресурc] URL: https://pravo.ru/story/204768/

6. Садовникова Г.Д. Особенности преподавания дисциплин государственного правового цикла с применением интерактивной методики // Актуальные проблемы российского права. 2017. № 2 (75) февраль с. 37-44. [Электронный pecypc] URL: https://cyberleninka.ru/article/n/osobennostiprepodavaniya-distsiplin-gosudarstvenno-pravovogo-tsikla-s-primenenieminteraktivnoy-metodiki

7. Михалкин Н.В., Кафырин Е.А. Содержание и структура методики преподавания юридических наук в высших учебных заведениях //Известия МГТУ «МАМИ» № 4(18), 2013, т. 2.c. 303-315. [Электронный ресурс] URL: 
https://cyberleninka.ru/article/n/soderzhanie-i-struktura-metodiki-prepodavaniyayuridicheskih-nauk-v-vysshih-uchebnyh-zavedeniyah/viewer

8. Н.Ф. Бабаев. Образовательные технологии как методика преподавания юридических дисциплин // мир науки, культуры, образования. № 6 (73) 2018. С.243-244

9. Лысаков, В.А. Современные методы преподавания юридических дисциплин / В.А. Лысаков. - Текст : непосредственный // Молодой ученый. 2019. — № 42 (280). — C. 276-278. — URL: https://moluch.ru/archive/280/63102/ (дата обращения: 27.02.2021).

10. Образовательные комиксы. [Электронный pecypc] URL: https://dic.academic.ru/dic.nsf/ruwiki/1583722

11. Иллюстрированная Конституция России. [Электронный ресурc] URL: https://ru.wikipedia.org/wiki/Иллюстрированная_Конституция_России

12. Образовательный потенциал комикса. Какие программы можно использовать для создания картинок и на каком уроке. [Электронный ресурс] URL: $\quad$ https://infourok.ru/obrazovatelniy-potencial-komiksa-kakie-programmimozhno-ispolzovat-dlya-sozdaniya-kartinok-i-na-kakom-uroke-2559700.html

13. Онкович А.В. Комиксы как форма визуальной медиакоммуникации. [Электронный pecypc] URL: http://dspace.kpfu.ru/xmlui/bitstream/handle/net/ 30146/viscom2014-85-92.pdf

14. Нужны ли образовательные комиксы в школе? [Электронный ресурс] URL: http://didaktor.ru/nuzhny-li-obrazovatelnye-komiksy-v-shkole/

15. Авдеева Т.И., Высокос М.И., Зыкова С.И. Комикс как современная технология обучения. [Электронный ресурс] URL: https://cyberleninka.ru/article/ n/komiks-kak-sovremennaya-tehnologiya-obucheniya 
УДК 372.891

\title{
ЭКОЛОГИЧЕСКОЕ ВОСПИТАНИЕ ШКОЛЬНИКОВ НА УРОКАХ ГЕОГРАФИИ И ВО ВНЕКЛАССНОЙ РАБОТЕ ПО ПРЕДМЕТУ
}

\section{Чуешкова Алла Анатольевна}

\begin{abstract}
Аннотация: представленный опыт может быть использован учителями географии при организации работы по экологическому воспитанию школьников. Все перечисленные методы и приемы работы могут быть включены в структуру урока в зависимости от целей и задач учебного занятия, могут использоваться во внеклассной работе по предмету.

Ключевые слова: экологическое воспитание, экологическая культура, метод, прием, этап урока, дидактические задания.

\section{ENVIRONMENTAL EDUCATION OF SCHOOLCHILDREN IN GEOGRAPHY LESSONS AND IN EXTRACURRICULAR WORK ON THE SUBJECT}

\section{Chueshkova Alla Anatolievna}

\begin{abstract}
: the presented experience can be used by geography teachers in organizing work on environmental education of schoolchildren. All of these methods and techniques can be included in the structure of the lesson, depending on the goals and objectives of the training session, and can be used in extracurricular work on the subject.
\end{abstract}

Key words: ecological education, ecological culture, method, technique, stage of the lesson, teaching jobs.

\section{ВВЕДЕНИЕ}

История человечества неразрывно связана с историей природы. Па современном этапе вопросы традиционного взаимодействия ее с человеком выросли в глобальную экологическую проблему. Если люди в ближайшем будущем не научаться бережно относиться к природе, они погубят себя. Для этого надо воспитывать экологическую культуру и ответственность. И начинать 
экологическое воспитание надо с младшего школьного возраста, так как в это время приобретенные знания могут в дальнейшем преобразоваться в прочные убеждения.

Довольно долго экологическому воспитанию не уделялось должного внимания. В последние годы школа сделала решительный поворот к изменению сложившегося положения.

Сегодня созданы предпосылки для развития системы непрерывного экологического образования и воспитания. Многие образовательные учреждения разных видов (школы, гимназии, лицеи и др. ) уже включили в свои учебные планы учебные предметы экологического направления. Однако статус образовательной области "экология" еще не утвердился, в большинстве школ занятия по экологии проводятся в форме факультатива или предмета по выбору. Невелик также престиж школьного экологического образования. Термин "экологическое образование и воспитание" был принят в результате расширения целей и задач педагогической деятельности.

Таким образом, актуальность проблем экологического образования и воспитания возрастает. Это вызвано:

- необходимостью повышения экологической культуры человека;

- необходимостью сохранения и восстановления, рационального использования и приумножения природных богатств;

- низким уровнем восприятия человеком экологических проблем как лично значимых;

- недостаточно развитой у человека потребностью практического участия в природоохранной деятельности.

\section{1. Система экологического образовании и воспитании: сущность, принципы, цель, задачи, формы, методы}

Образование и воспитание школьников в области окружающей среды является в настоящее время одним из приоритетных направлений работы с молодежью. Чем раньше начинается формирование экологической культуры у детей, чем целесообразнее организовать этот процесс, тем выше эффективность воспитания. Научная организация процесса экологического воспитания требует четкого определения всех его звеньев, выявления связей и зависимостей

Экологического образования и воспитания - это специальный, целенаправленный, организованный, систематичный, последовательный, 
планомерный педагогический процесс формирования системы экологических знаний, умений, навыков, взглядов, убеждений, нравственных качеств, обеспечивает становление и развитие у личности ответственного отношения $\kappa$ природе как к универсальной ценности. [3. С.75]. Таким образом, основной целью экологического образования и воспитания является формирование экологической культуры школьников. Цель экологического образования и воспитания обуславливает следующие актуальные задачи:

- усвоение ведущих идей, основных понятий и научных фактов, на основе которых определяется оптимальное воздействие человека на природу и природы на человека;

- понимание многосторонней ценности природы как источника материального и духовного развития общества;

- овладение прикладными знаниями, практическими умениями и навыками рационального природопользования, развитие способности оценить состояние природной среды, принимать правильные решения по се улучшению;

- выработка умений предвидеть возможные последствия своей деятельности в природе;

При этом под экологической культурой понимается качество личности, включающее в себя следующие компоненты:

интерес к природе;

знания о природе, взаимосвязях в природе, воздействии человека на природу; чувства эстетические и нравственные;

позитивная деятельность и поведение в природе;

мотивы деятельности в природе гуманистические, познавательные, эстетические, санитарно-гигиенические, утилитарные и др.

Принципы организации экологического воспитания:

1. Процесс формирования ответственного отношения к природе является составной частью общей системы воспитания, актуальным ее направлением.

2. Процесс формирования экологической культуры строится па взаимосвязи глобального, регионального и краеведческого подходов к раскрытию современных экологических проблем.

3. В основе формирования бережного отношения к природе лежит единство интеллектуального, эмоционального восприятия окружающей среды и практической деятельности по ее улучшению.

4. Процесс формирования экологической культуры школьников опирается на принципы систематичности, непрерывности, и 
междиспиплинарности в содержании и организации экологического образования [1. С.65].

Систему экологического воспитании составляют звенья:

экологическое воспитание в семье;

экологическое воспитание в дошкольных учреждениях;

экологическое воспитание в школе (в учебной и внеурочной работе); экологическое воспитание в детских внешкольных учреждениях; экологическое воспитание в лагерях летнего отдыха; самообразование и самовоспитание.

Наиболее действенным средством экологического воспитания является разнообразная деятельность детей (учебная, познавательная, художественная, творческая, игровая).

\section{2. Экологическое воспитание школьников на уроках географии и во внеклассной работе по предмету}

Формирование экологических знаний - один из этапов сложного взаимодействия обучающих и воспитательных задач. География знакомит учащихся с особенностями природного, социально-экономического и политического развития конкретных территорий, принципами рационального природопользования, охраной природной среды и бережливого отношения к природным ресурсам. Поэтому экологический аспект в географическом образовании представляет большое и важное значение, как в учебной деятельности, конкретно на уроках, так и, особенно, во внеклассной работе по предмету. Знания еще не могут дать желаемых результатов. Необходимы и действенные взаимоотношения, которые приведут к непосредственному контакту с природой. Формирование у школьников ответственного отношения к природе возможно только тогда, когда учащиеся сами принимают активное участие в решении жизненных задач, прямо или косвенно связанных с жизнью в природе.

Можно определить следующие направления работы:

усвоение определенных норм и правил общения с объектами живой природы; работа по развитию навыков исследовательской деятельности, обеспечивающая обогащение запаса знаний причинно-следственных связей обучающихся; формирование навыков обобщения и моделирования последствий вмешательства человека в природу, раскрывающих законы связи причины и следствия; 


\section{ТРАДИЦИИ И ИННОВАЦИИ В СОВРЕМЕННОЙ НАУКЕ И ОБРАЗОВАНИИ: ТЕОРИЯ И ПЕРЕДОВАЯ ПРАКТИКА}

изучение наиболее ярких примеров изменения человеком окружающей среды.

Главной особенностью является разнообразная деятельность школьников. Ее основные виды:

усвоение четко заданного образца ("технологически" построенная репродукция);

игровая деятельность;

учебно-поисковая деятельность (поиск и выработка нового знания, освоение нового опыта) в ее основных разновидностях;

систематический познавательный поиск по типу научного исследования; дискуссионная (диалоговая, коммуникативная) деятельность.

Данные виды деятельности различны на разных этапах изучения курса географии.

I этап - курс начальной географии, 6 - 7 класс.

На данном этапе основным направлением работы по формированию культуры природопользования является усвоение определенных норм и правил общения с объектами живой природы. Необходимо сформировать у школьников основные представления о Земле как о единстве целого («Земля планета людей»), состоящего из отдельных частей - оболочек (литосфера, гидросфера, атмосфера, биосфера). На этом же этапе развивается познавательный интерес, интеллектуальные и творческие способности в процессе наблюдений за состоянием окружающей среды, решения географических задач, самостоятельного приобретения новых знаний.

В результате такой работы учащиеся должны:

- знать и понимать основные географические понятия и термины; различия плана, глобуса и географических карт по содержанию, масштабу, способам картографического изображения; результаты выдающихся географических открытий и путешествий;

- уметь выделять, описывать и объяснять существенные признаки географических объектов и явлений.

- использовать навыки картографии и ориентирования на местности.

На первом этапе отдается предпочтение такому виду познания, как формирование общегеографических знаний.

Основной вид деятельности учащихся на данном этапе - это усвоение четко заданного образца ("технологически" построенная репродукция). Однако 
по завершении работы на данном этапе предполагается переход к следующему виду деятельности - учебно-поисковому.

Основные формы работы: урок, экскурсия, полевой практикум по составлению плана местности, описанию природного комплекса своей местности.

II этап - география, 8 класс. На данном этапе необходимо организовать деятельность учащихся, чтобы формировать определенную систему предметных знаний, развивать навыки исследовательской деятельности, обеспечивающей обогащение запаса знаний причинно-следственных связей учащихся, развивающей умения активно использовать приобретенные знания в знакомой ситуации, сравнивать и обобщать, находить причину, прогнозировать последствия, делать выводы.

В результате учащиеся должны:

- знать и понимать общие географические закономерности материков и океанов, отдельных стран и различных природных условий, особенности влияния природы на хозяйство, культуру;

- давать комплексную географическую характеристику материков, стран и океанов, специфику формирования их природно-ресурстного потенциала и особености их современного развития.

Основными формами работы на данном этапе являются урок, исследовательская работа, внеклассная работа по предмету. На втором этапе отдается предпочтение формированию навыков диалогового общения, работы в группах, исследовательской, проектной деятельности. Преобладающий вид деятельности учащихся - систематический познавательный поиск по типу научного исследования.

III этап - география - 9, 11 классы.

На данном этапе старшеклассники способны самостоятельно интегрировать новые знания в систему собственных знаний, умение проектировать новые способы решений, а также представлять их в виде проектов, презентаций.

На третьем этапе основной задачей является не только формирование системы географических знаний для выявления геоэкологических проблем на местности и по карте, но и вооружение учащихся способами применения полученного багажа знаний в повседневной жизни для сохранения и улучшения качества окружающей среды 
Более подробно необходимо остановиться на выборе форм и методов обучения. Основной формой построения образовательного процесса по географии является урок.

Кроме стандартного комбинированного урока, следует отметить уроки в форме пресс-конференций (например, «Экологические проблемы Мирового океана», 11 класс), отчета научной экспедиции в зону экологической катастрофы (например, «Экологические и техногенные катастрофы: Япония, Фокусима - 1», 9 класс), защиты проектов (например, Экологическая ситуация в поселке Большевик», 10 класс).

На третьем этапе предпочтение отдается формированию навыков работы с информацией: анализировать, моделировать, прогнозировать, диалогового общения, работы в группах, исследовательской, проектной деятельности.

Основной вид деятельности - дискуссионная (диалоговая, коммуникативная) деятельность.

Следует отметить, что на каждом этапе изучения географии необходимо использовать краеведческий материал, так как это способствует активизации мыслительной деятельности школьников. Они учатся сравнивать характеристики компонентов природы своего края с компонентами природы территорий, использовать краеведческий материал в качестве исходного для постановки вопросов и заданий проблемного характера, создания проблемных ситуаций. Краеведческий материал также может использоваться и в качестве источника для выполнения практических и самостоятельных работ, демонстрации натуральных местных объектов, моделей, образцов горных пород и минералов, коллекций почв, растений. Выполнение письменных самостоятельных работ по характеристике объектов, явлений, процессов (сообщения, альбомы, отчеты по экскурсиям, наблюдениям) важно для изучения предмета с целью определения взаимосвязей между человеком и природой.

Необходимо отметить, что очень важно и обязательно знакомство учащихся с экологическими проблемами своего края, красотой родной природы. Это позволяет сформировать интерес к экологическим знаниям, чувство экологической ответственности. Кроме того, отношения с природой способствуют развитию эмоциональной культуры, создают богатый запас переживаний. Например, с учащимися 11 класса можно организовать 
«Экологический проект»: загрязнение атмосферы; загрязнение почвы; загрязнение воды.

В процессе изучения географии возможно использование элементов технологии проектного обучения. Именно метод проектов позволяет учащимся рассматривать изучаемые вопросы более широко и использовать окружающую среду, окружающую жизнь как лабораторию, в которой происходит процесс познания. Исследовательские задания являются логическим продолжением творческих заданий, при выполнении которых проводится теоретическое или экспериментальное исследование проблемы. Их выполнение закрепляет основные знания и умения в форме научных убеждений в сознании учащихся. Творческие задания формируют познавательные, исследовательскосозидательные качества личности.

Кроме этого, на уроках географии во всех классах эффективны методы и приемы технологии критического мышления.

Например: 7 класс. Тема: «Океаны» При обобщении изученного по теме учащимся предлагается составить РАФТ «Индийский океан». Обращение океана к человеку: «Люди стали осваивать мои просторы еще в $V$-IV mыс. до н.э. И сейчас на моих берегах живет более 1 млрд. человек. Сначала по моим просторам плавали парусники, суда ходили лишь при попутном ветре. Известный английский мореплаватель Джеймс Кук в ХVIII веке провел первые промеры моих глубин. Многие мои тайны пытаются раскрыть океаногографические экспедиии. Я щедро отдаю людям мои природные ресурсы: биологические, минеральные, энергетические, химические. Мои теплье воды омывают крупные государства и острова. Красота моих побережий $и$ коралловых островов привлекает туристов из разных стран.

В северо-западной части моих просторов, в Персидском заливе, расположены крупнейтие в мире запасы нефти и газа. Нефть добывают $и$ перевозят на нефтяных танкерах, но из-за аварий па нефтяных танкерах происходит загрязнение моих вод.

Используя мои ресурсы, чем платят мне люди?

На мою территорию сбрасывают много отходов: мазут, пластмассу, промышленный мусор - это дары океану от современного человека!

Люди! Прекратите сброс отходов в мои воды. Моими богатствами должны пользоваться ваши дети и внуки! Оставьте живой океан!» 


\section{ТРАДИЦИИ И ИННОВАЦИИ В СОВРЕМЕННОЙ НАУКЕ И ОБРАЗОВАНИИ: ТЕОРИЯ И ПЕРЕДОВАЯ ПРАКТИКА}

Использование данных форм обучения нацелено на организацию деятельности учащихся с различными источниками знаний. Они приобретают умения наблюдать, измерять, добывать информацию из бесед с окружающими, фиксировать полученные знания, результаты проведенных экспериментов, овладевают навыками работы в команде. Такая организация работы позволяет расширить образовательный процесс за пределы урока, развить навыки самообразования, анализа, исследовательской деятельности.

При выборе методов и форм обучения обязательно учитываются возрастные и психологические особенности учащихся каждого классного коллектива: в 6-7 классах у школьников преобладает конкретно-образное и наглядно-действенное мышление; с возрастом развивается словесно-логическое мышление, поэтому очень важно в своей деятельности определить соотношение общего и единичного. Оно должно изменяться в сторону от единичного, конкретного - к обобщенным теоретическим знаниям внутри каждого курса («по горизонтали») и от начального курса географии до последнего курса («по вертикали»), в связи с этим, в 6-7 классах активно используется технология игровой деятельности. В 8-9 классах в курсе «Страноведение» используется технология проблемного обучения, и продолжается практика использования технологии игровой деятельности, но здесь уже применяются деловые (ролевые) игры. Выбор данного направления игр объясняется тем, что в подростковом возрасте наблюдается обострение потребности в создании своего собственного мира, в стремлении к взрослости, бурное развитие воображения, фантазии, появление стихийных группировок.

Большое значение уделяется экскурсионной работе по местным объектам природы (парки, скверы) и хозяйственной деятельности человека (заводы, технические сооружения). В старших классах начинается использование лекционно-семинарско-зачетную форму обучения, особенно при изучении тем, которые включают в себя несколько занятий, и в то же время, продолжается практика использования деловых игр, особенности которых в старшем возрасте определяются нацеленностью личности на самоутверждение перед обществом, ориентацией на речевую деятельность.

Важно, что одним из принципов формирования духовно-нравственного потенциала и экологического образования является наглядность, которая обусловлена особенностями восприятия и развития мышления учащихся. Человек черпает свои знания из внешнего мира при помощи органов чувств, а 
наглядные пособия служат источником информации для учащихся. Наблюдая демонстрируемые объекты, учащиеся самостоятельно или с помощью вопросов обдумывают выводы, делают обобщения и умозаключения, у них развиваются память, речь и воображение.

Демонстрация наглядных средств сопровождается постановкой проблемных вопросов, требующих от учащихся анализа наглядного средства или творческой работы с оборудованием. В системе средств обучения большое значение отдается учебнику, поскольку он является центральным, связующим звеном в системе географического образования школьников. Однако учебник не может в полной мере решить задачи развития духовно-нравственного потенциала учащихся и активизации их познавательного интереса.

Важно применять на уроках целый комплекс различных средств обучения: средства массовой информации, технические средства обучения (компьютер, телевизор, магнитофон); натуральные объекты и приборы, изображения и отображения предметов и явлений (модели, муляжи, макеты, таблицы, карты, картины); книги для чтения учащихся; энциклопедическая литература; периодическая печать; учебно-методические пособия для учителей (дидактические и методические пособия, справочная и научная литература).

Для формирования и развития экологической культуры школьников в процессе обучения не последнее место принадлежит занимательности. Занимательные вопросы и задания, всевозможные викторины и вечера, развивающие и познавательные игры и множество других средств помогут сделать предмет интересным для учащихся.

Известно, что в играх дети проявляют воображение, сообразительность, наблюдательность, находчивость, учатся быстро и логично рассуждать. В коллективной игре почти всегда есть элемент соревнования (кто быстрее, правильнее ответит, кто больше знает), а значит, есть и усилие воли, настойчивость, внимание. "В каждой хорошей игре есть прежде всего рабочее усилие и усилие мысли" (А.С. Макаренко) [9. С.8].

В познавательной географической игре закрепляются умение применять полученные раннее знания, навыки пользования справочной и другой литературой. А главное - в процессе игры школьники получают знания, испытывая при этом удовольствие. Положительные эмоции сказываются на лучшем усвоении изучаемого материала, влияют на развитие личности ребёнка в целом. Вот почему игра может стать средством всестороннего развития школьника, его способностей. 
Как пример, можно привести несколько подвижных географических игр.

Игра “Раз! Два! Три!” (5 класс, тема «Вода»; 6 класс, тема «Гидросфера».

Участники игры берутся за руки и образуют круг. Начиная движение по часовой стрелке, они произносят слова: “Раз! Два! Три! Море назови!” При последних словах все останавливаются и начинают по очереди перечислять названия морей. Если кто-нибудь промолчит, то он выбывает из игры.

Игра со словами: “Раз! Два! Три! Остров (горы, реки, город) назови!» продолжается, пока не останется минимальное количество участников.

Игра “Широта и долгота" (6 класс, «Географические координаты»; 8 класс).

Участники игры (их должно быть не менее 4 человек) делятся на четыре группы. Первая - “северные широты”, вторая - “южные широты”, третья “восточные долготы”, четвёртая - “западные долготы”. Игроки вперемежку выстраиваются в шеренгу. Ведущий называет любой географический объект, участники игры быстро вспоминают, где он находится. Те, которые представляют “широты” и “долготы” этого объекта, должны быстро присесть. Например, ведущий называет: остров Мадагаскар; приседают ребята, изображающие “южные широты” и восточные долготы”. Кто ошибся получает штрафное очко, а при повторной ошибке выбывает из игры.

Очень важной деталью в экологическом образовании является использование музыкальных фрагментов, как на уроках, так и во внеклассной работе по предмету. Современная школа позволяет организовывать этот процесс. Природа и музыка, музыка и Природа - эти два слова просто неотъемлемы друг от друга и чем-то очень похожи. В самом слове «музыка» слышатся задорный птичий гомон, перезвон озерных ручейков, задумчивый шелест листвы и эхо морского прибоя.

Голоса природы можно найти в музыкальных произведениях Ф. Шуберта, М. Глинки, Сен-Санса, Р. Шумана. Создать на уроке, факультативе, внеклассном мероприятии эмоциональный настрой помогает музыка П.И. Чайковского «Времена года», вальс цветов из балета «Щелкунчик» и др.

Для формирования экологического воспитания учащихся важное значение имеет системность и комплексность работы. Важно понимать, что силами одного предмета, одного учителя вырастить духовную, нравственную, творческую личность невозможно. Вопросы воспитания и здоровье сбережения 
учащихся рассматриваются на заседаниях педагогического совета школы. Для систематизации внеурочной работы по предмету проходит работа в тесном сотрудничестве с учителями методического объединения естественно географического цикла. Это сотрудничество даёт положительные результаты в организации предметных недель, научных конференций, проектной деятельности, повышает интерес к предмету.

\section{ЗАКЛЮЧЕНИЕ}

В представлении В.И. Вернадского, человек - часть живого вещества, подчиненного общим законам организованности биосферы, вне которой оно существовать не может. Человек является частью природы. Целью общественного развития должно быть сохранение организованности окружающей среды. А для этого необходимо формировать высокий уровень экологической грамотности населения, а в первую очередь подрастающего поколения. Экологическая культура нужна каждому, кто собирается жить в 21 веке.

Экологическое образование и воспитание - целенаправленный, организованный процесс формирования умений, навыков, взглядов и убеждений, обеспечивающих развитие бережного и ответственного отношения к природе.

Ежегодно проводится исследование экологической культуры учащихся школы, связанное с проблемами экологии. Результаты последнего анкетирования учащихся 8-11 класса показали, что учащиеся на достаточном уровне владеют знаниями экологической культуры и их практическим применением. Так, $86 \%$ учащихся знают, что такое экология; $75 \%$ учащихся при изучении вопросов экологии больше узнали, как сохранить свое здоровье, $94 \%$ - стали понимать значимость воды, воздуха для человека, $82 \%$ - получили более глубокие знания о природе.

Исходя из вышеизложенного, можно отметить, что на данном этапе развития общества возможно воспитание подрастающего поколения и формирование высокой культуры учащихся, способных принимать оптимальные решения по отношению к природе и обществу, быть ответственными за сохранение жизни на земле и считать себя экологически культурными людьми. 


\section{Список литературы}

1. Андреенко, В.М. Активные формы и методы в обучении географии / В.М. Андреенко. - М.: Изд-во ИГПИ, 1999. - 288 с.

2. Географический энциклопедический словарь. - М. Большая Российская Энциклопедия, 2003. - 600 с.

3. Гладкий, А.Г. Глобальная география / А.Г.Гладкий. - И., 2002. - 215 с.

4. Данилова, Н.Н. Экологическая тропа - средство экологогеографического воспитания школьников / Н.Н.Данилова // География и экология. - 2008. - №10. - С. 18-26.

5. Жук, О.Л. Педагогичекие технологии в современной теории и практике образования / О.Л.Жук. - М., 2002. - 150 с.

6. Исаченко, А.Г. Введение в экономическую географию / А.Г.Исаченко. - Изд-во СпбГУ, 2003. - 192 с.

7. Карпова, Г.Н. Экологическое образование школьников: ведущие тенденции и парадигмальные сдвиги / Г.Н.Карпова. - Мн., 2001. - 189 с.

8. Кашлев С.С. Интерактивные методы развития экологической культуры учащихся / Кашлев С.С. - Мн., 2007. -148 с.

9. Кузнецова, Н.М. Экологическое образование в современной школе / Н.М. Кузнецова // География и экология. - №7. - С.6-12.

10. Логинова, В.Ф. Прогноз измерения окружающей природной среды Беларуси на 2010 - 2020 гг.. / В.Ф.Логинова. - М., 2004. - 247 с.

11. Мениченко, Е.Н. Основы экологии / Е.Н.Миниченко. - Мн., 2002. $400 \mathrm{c}$.

12. Максаковский, В.П. Географическая культура / В.П.Максаковский. M., 1998. -318 c.

13. Резонов, И.А. Великие катострофы в истории земли / И.А.Резонов. М.: Наука, 1984. - 325.

14. Экологический взгляд / Н.В.Самерсова [и др.]. - Мн., 2002. - 135 с.

15. Чырвоная кніга Беларусі. - 3-е выд. - Мн., 2004. - 460 с. 
УДК 373.21

\title{
ОСНОВНЫЕ ТРЕБОВАНИЯ К ДВИГАТЕЛЬНОЙ ПОДГОТОВКЕ ДЕТЕЙ 6-7 ЛЕТ
}

Жигайлова Лариса Валентиновна доцент, кандидат педагогических наук Свистун Галина Михайловна доцент

Тихонова Ирина Владимировна профессор, кандидат педагогических наук Барчо Ольга Федоровна старший преподаватель ФГБОУ ВО «Кубанский государственный университет физической культуры, спорта и туризма»

Аннотация: в исследовании рассмотрены общие представления о движении и основных двигательных способностях детей 6-7 лет.

Рассмотрены физиологические процессы формирования основных физических качеств детей 6-7 лет. Даны рекомендации к содержанию занятий по совершенствованию двигательной подготовки детей младшего школьного возраста.

Ключевые слова: прыжки на батуте, координационные способности, тренировочный процесс.

\section{BASIC REQUIREMENTS OF THE ENGINE PREPARATION OF CHILDREN 6-7 YEARS}

\author{
Zhigailova Larisa Valentinovna \\ Svistun Galina Mikhailovna \\ Tikhonova Irina Vladimirovna \\ Barcho Olga Fedorovna
}

\begin{abstract}
: the study examines general ideas about movement and basic motor abilities of children aged 6-7 years.
\end{abstract}


The physiological processes of the formation of the basic physical qualities of children aged 6-7 years are considered. Recommendations are given for the content of classes to improve the motor training of children of primary school age.

Key words: jumping on a trampoline, coordination abilities, training process.

В современных условиях дефицита учебного времени, малого времени на выполнение упражнений в видах спорта, а также системности освоения юными спортсменами рациональных способов управления своими движениями для приобретения жизненно необходимого фонда двигательных умений, навыков и связанных с ними знаний требует новых подходов к интенсификации процесса обучения.

Все это заставляет выдвигать задачи поиска новых, более рациональных путей освоения знаний, умений и необходимых практических навыков детей.

Осмысление внутреннего содержания двигательного действия необходимы для эффективной методики обучения выполнения всех упражнений в любом виде спорта, а также возможности повышения интереса к занятиям спортом. В процессе выполнения сложнокоординационных ациклических упражнений, упражнений циклического характера (бег, ходьба, прыжки и т.д.) на занятиях у детей приобретаются двигательные умения и навыки.

Общие представления о движении и двигательной подготовке. Движение - это двигательные действия (перемещение организма и его звеньев), выполняемые с определенной целью. Так же движение это моторная функция организма.

Двигательная активность человека - это совокупность всех двигательных актов, так же одно из важных условий поддержания оптимального функционального состояния здоровья человека. Нормальная работа практически всех функций и систем человека возможна лишь при определенном уровне двигательной активности.

Для человека недостаток двигательной активности все равно, что кислородное голодание, пагубно влияет как на организм взрослого человека, так и на ребенка. Двигательная активность человека бывает недостаточной, оптимальной и избыточной. Людям необходимо придерживаться оптимальной двигательной активности, которая в свою очередь зависит от возраста, пола, уровня физической подготовленности и многих других факторов. 


\section{ТРАДИЦИИ И ИННОВАЦИИ В СОВРЕМЕННОЙ НАУКЕ И ОБРАЗОВАНИИ: ТЕОРИЯ И ПЕРЕДОВАЯ ПРАКТИКА}

Физические качества - это всестороннее развитие двигательных возможностей человека, а так же степень овладения конкретными двигательными действиями. От степени развития физических качеств таких как: быстрота, ловкость, сила, гибкость и выносливость зависят дальнейшие показатели в избранных видах спорта.

Физическая подготовка - это педагогический процесс, направленный на воспитание физических качеств. Физическая подготовка включает общую и специальную физические подготовки.

Физическая подготовленность - это результат физической подготовки, достигнутый при выполнении двигательных действий для данного вида деятельности.

Есть два термина «подготовка» обозначающая процесс и «подготовленность» обозначающая результат процесса. Сочетание данных терминов приводит нас к пониманию, что речь идет о контроле физической подготовленности как результата физической подготовки.

Двигательно-координационная подготовка в спорте. Под двигательнокоординационными способностями понимаются способности быстро, точно, целесообразно, экономно, т.е. наиболее совершенно, решать двигательные задачи.

Объединяя целый ряд способностей, относящихся к координации движений, их можно в определенной мере разбить на три группы (рис. 1).

Первая группа. Способности точно соизмерять и регулировать пространственные, временные и динамические параметры движений

Вторая группа. Способности поддерживать статическое (позу) и динамическое равновесие.

Третья группа. Способности выполнять двигательные действия без излишней мышечной напряженности (скованности).

\section{Рис. 1. Группы координационных движений}


Проявление координационных способностей зависит от целого ряда факторов (рис. 2).

Способность же быстро и целесообразно преобразовывать движения и формы действий по ходу состязаний в наибольшей мере требуется в спортивных играх, единоборствах. Также в таких видах спорта, как скоростной спуск на лыжах, горный и водный слалом, где в обстановку действий преднамеренно вводят препятствия, которые вынуждают мгновенно видоизменять движения или переключаться с одних точно координированных действий на другие.

от способности человека к точному анализу движений

от деятельности анализаторов и особенно двигательного

от сложности двигательного задания

от уровня развития других физических способностей (скоростные

способности, динамическая сила, гибкость и т.д.)

от общей подготовленности занимающихся (т.е. запаса разнообразных, преимущественно вариативных двигательных умений и навыков) и др.

от смелости и решительности; от возраста занимающихся

\section{Рис. 2. Факторы, влияющие на проявление координационных способностей}

В указанных видах спорта стремятся довести координационные способности, отвечающие специфике спортивной специализации, до максимально возможной степени совершенства.

Многие существующие и вновь возникающие в связи с научнотехническим прогрессом виды практической профессиональной деятельности 
не требуют значительных затрат мышечных усилий, но предъявляют повышенные требования к центральной нервной системе человека, особенно к механизмам координации движения, функциям двигательного, зрительного и других анализаторов.

Основным средством воспитания координационных способностей являются физические упражнения повышенной координационной сложности и содержащие элементы новизны.

Наиболее широкую и доступную группу средств для воспитания координационных способностей, составляют общеподготовительные гимнастические упражнения динамического характера, одновременно охватывающие основные группы мышц. Это упражнения без предметов и с предметами (мячами, гимнастическими палками, скакалками, булавами и др.), относительно простые и достаточно сложные, выполняемые в измененных условиях, при различных положениях тела или его частей, в разные стороны: элементы акробатики (кувырки, различные перекаты и др.), упражнения в равновесии.

Большое влияние на развитие координационных способностей оказывает освоение правильной техники естественных движений; бега, различных прыжков (в длину, высоту и глубину, опорных прыжков), метаний, лазанья.

Для воспитания способности быстро и целесообразно перестраивать двигательную деятельность в связи с внезапно меняющейся обстановкой высокоэффективными средствами служат подвижные и спортивные игры, единоборства (бокс, борьба, фехтование), кроссовый бег, передвижения на лыжах по пересеченной местности, горнолыжный спорт.

Особую группу средств составляют упражнения с преимущественной направленностью на отдельные психофизиологические функции, обеспечивающие управление и регуляцию двигательных действий. Это упражнения по выработке чувства пространства, времени, степени развиваемых мышечных усилий.

Специальные упражнения для совершенствования координации движений разрабатываются с учетом специфики избранного вида спорта, профессии. Это координационно-сходные упражнения с технико-тактическими действиями в данном виде спорта или трудовыми действиями.

При воспитании координационных способностей используются следующие методические принципы (рис. 3).

При разучивании новых достаточно сложных двигательных действий 


\section{ТРАДИЦИИ И ИННОВАЦИИ В СОВРЕМЕННОЙ НАУКЕ И ОБРАЗОВАНИИ: ТЕОРИЯ И ПЕРЕДОВАЯ ПРАКТИКА}

применяют стандартно-повторный метод, так как овладеть такими движениями можно только после большого количества их повторений в относительно стандартных условиях.

Метод вариативного упражнения со многими его разновидностями имеет более широкое применение. Его подразделяют на два подметода - со строгой и нестрогой регламентацией вариативности действий и условий выполнения.

Эффективным методом воспитания координационных способностей является игровой метод с дополнительными заданиями и без них, предусматривающий выполнение упражнений либо в ограниченное время, либо в определенных условиях, либо определенными двигательными действиями и Т.П.

Обучение новым разнообразным движениям с постепенным увеличением их координационной сложности

Воспитание способности перестраивать двигательную деятельность в условиях внезапно меняющейся обстановки

Повышение пространственной, временной и силовой точности движений на основе улучшения двигательных ощущений и восприятий

Преодоление нерациональной тонической и координационной мышечной напряженности:

а) упражнения в растягивании, преимущественно динамического характера;

б) разнообразные маховые движения конечностями в расслабленном состоянии;

в) плавание;

г) массаж, сауну, тепловые процедуры.

Координационная напряженность (неполное расслабление мышц в процессе работы или их замедленный переход в фазу расслабления)

Рис. 3. Методические принципы для воспитания координационных способностей 
Соревновательный метод используется лишь в тех случаях, когда занимающиеся, достаточно физически и координационно подготовлены в соревновательных упражнениях.

Некоторые контрольные упражнения для определения уровня координационных способностей это:

- «бег по заданным ориентирам»;

- «челночный бег $3 \times 10$ м»;

- «челночный бег 4x9 м с последовательной переноской двух кубиков за линию старта»;

- «метание мяча в цель с различного расстояния и из различных исходных положений»;

- «комбинированные полосы препятствий» т.д.

Знание возрастных особенностей строения и функций организма, как в целом, так и отдельных систем и органов, необходимы для правильной разработки и постановки учебно-воспитательной работы с детьми. Поэтому в общеобразовательных и учреждениях дополнительного образования выделен определенный период для обучения детей в школе. Именно, а данное время ребенок привыкает к новой среде и условиям существования, которую школьник (ребенок) переносит индивидуально.

В первое время обучения у новоиспеченных первоклассников наблюдаются неблагоприятные сдвиги сердечнососудистой и нервной систем (становятся более эмоциональней), снижение или прирост темпов нарастания массы тела ребенка, изменения специфической и неспецифической реактивности организма. Адаптация ребенка протекает индивидуально, поэтому имеются значительные различия. Адаптация примерно длится на протяжении 5-6 недель, наиболее сложными являются 1-4 недели.

В период 6-7 лет завершается формирование многих отделов головного мозга. На этапе перехода ребенка из «дошкольного детства» в «младший школьный» происходит «кризис 7 лет». Не каждый семилетний ребенок, а тем более шестилетний, психически и физически готовы к обучению и новому режиму дня.

К уровню готовности ребенка к выполнению заданий школьной программы и посещения спортивных секций относят (рис. 4). 
Физическая готовность - это общее физическое развитие (рост, вес, мышечный тонус, зрение, слух, моторика). Особенно моторика мелких движений, определяет соматическую зрелось

Интеллектуальная готовность - это не только словарный запас и кругозор ребенка, но и уровень познавательных процессов

Личностная и социально-психологическая готовность - нравственные качества общения с взрослыми и сверстниками, а так же «внутренняя позиция школьника»

\section{Рис. 4. Основные виды готовности ребенка к выполнению заданий учебного и двигательного материала}

Для улучшения усвоения материала в процессе образования и адаптации шестилеток необходимо составить особый режим учебной работы, а так же обеспечить двигательную деятельность, которая поддерживает оптимальное состояние кардиореспираторной системы, терморегуляции, упражнения аэробного характера, чтобы предотвратить гипокинезию.

Существует проблема поддержания высокой физической активности у детей 6-7 лет. Данную проблему можно быстро решить с помощью равномерного сочетания учебной деятельности и физической активности в течении дня.

Методика обучения детей физическому воспитанию должна отвечать их психофизиологическим и морфофункциональным особенностям развития их организма. Безусловно, на состояние здоровья детей влияет многие факторы, такие как гигиена, социальные и экологические условия развития, но и в то же время к негативному влиянию можно отнести школьный фактор (длительное времяпровождение за партой, способствующее хроническим заболеваниям, связанных с позвоночным столбом).

Поэтому необходимо фокусировать максимальное внимание на 
позвоночник ребенка. Для этого необходимо особое внимание уделить введению физкультминуток на уроках.

Физкультминутки должны предоставлять небольшой комплекс физических упражнений. Упражнения в свою очередь должны быть подобраны так чтобы затрагивать различные группы мышц. Значение физкультминуток заключается в снятие утомления у ребенка, повышение умственной работоспособности детей. Такие двигательные нагрузки дают отдых мышцам, органам слуха и восстанавливают силы ребенка.

Доказано, что у детей 6-7 лет гораздо быстрее увеличиваются резервные возможности сердечнососудистой и дыхательной систем. За счёт этого ребенок может выполнять длительное время аэробную работу умеренной интенсивности.

Сердечнососудистая система шестилетнего ребенка способна обеспечить потребность организма, при выполнении нагрузок направленных на развитие выносливости, на 60-70\% от максимальной возможности.

Появляются возможности развития выносливости детей 6-7 лет с помощью массового внедрения циклических комплексов физических упражнений в занятия физической и физкультурно-оздоровительной культурой.

В возрасте 6-7 лет выполнение упражнений оказывают благоприятное воздействие, способствует развитию всех физических качеств, получению навыков на освоение новых движений.

Освоению более сложных по координации двигательных действий способствует комплексное совершенствование физических качеств с направленным развитием выносливости.

На начальном этапе обучения закладывается фундамент физического развития. В дальнейшем он будет приносить успехи в умственной, спортивной и трудовой деятельности.

У детей младшего школьного возраста хорошо проявляется способность к выполнению кратковременных скоростно-силовых упражнений, а так же упражнения на координацию движений (разновидности прыжков, отдельные акробатические упражнения так и их комбинации, упражнения на снарядах).

В этом возрасте сложно выполнять упражнения статического характера, поэтому у детей происходит быстрое утомление. При удержании определённой позы, например при письме, необходимо длительное напряжение спинных мышц, которые недостаточно развиты у детей. 
Однако для поддержания правильной осанки необходимо выполнять контролируемые статические усилия. В профилактических целях большое внимание нужно уделять развитию всех мышц туловища.

Своевременному формированию и успешной перестройке всех психических процессов в значительной мере содействует целенаправленная двигательная деятельность.

Помимо формирования необходимых умений и навыков: бега, ходьбы, метаний, прыжков, на занятиях физической культурой необходимо стимулировать детей к получению навыка сохранять правильную осанку, контролировать действия своего тела, а также справляться с тактическими задачами.

В данный возрастной период у детей недостаточно развито устойчивое внимание. У них преобладает высокая эмоциональность, а так же сильно развита потребность в постоянных движениях.

Если нет возможности удовлетворять эту потребность у ребенка возрастает мышечное напряжение, внимание падает, быстро наступает утомление. За счет активных движений младшие школьники справляются с усталостью. Младшие школьники за счет движений сопротивляются утомлению, что является защитной физиологической реакцией.

Таким образом, детям 6-7 лет можно рекомендовать:

1. Упражнения на формирование правильной осанки.

Для этого в учебных занятиях необходимо использовать:

- разновидности ходьбы с положениями рук;

- общеразвивающие упражнения с контролем положений верхнего плечевого пояса (спина прямая, лопатки соединены и тд.);

2. Упражнения для развития вестибулярного аппарата.

Для этого в учебных занятиях необходимо использовать:

- быстрые движения готовой в различных направлениях: повороты направо/налево, наклоны головы вперед/назад с различными временными отрезками;

- быстрые движения туловищем в различных направлениях: повороты направо/налево, наклоны туловища вперед/назад, вправо/влево с различными временными отрезками;

- повороты переступаниями и прыжком на $180^{\circ}, 360^{\circ}$ и более градусов;

- разновидности ходьбы с изменением темпа, со сменой направления 
движения, с заданиями игровой направленности (по сигналу, по ориентиру, вызов номеров и др.);

- упражнения со зрительным и без зрительного контроля.

3. Формировать запас двигательных навыков, позных ориентиров, используя «школу движений» (положения рук, ног, головы, туловища). «Школа» снижает тревожность перед выполнением сложного элемента, требующего для ребенка риска. После занятий «школой» появляется приподнятое настроение, уверенность в своих физических возможностях, исчезает раздражительность.

Обучение «школе движений» требует от детей времени, терпения, так кК выполнять эти упражнения необходимо регулярно на каждом занятии, что способствует в дальнейшем улучшению координационных способностей и создает дополнительный запас двигательных навыков.

\section{Список литературы}

1. Анцыперов, В.В. Совершенствование технологии обучения юных спортсменов / В.В. Анцыперов, Т.А. Легкодимов // Вестник УГТУ-УПИ. Екатеринбург: УГТУ-УПИ, 2006. - №10. - Вып. 6. - Т.2. - С.66-70.

2. Аршинник, С.П. Использование данных мониторинга физической подготовленности для подготовки школьников к выполнению нормативных требований ВФСК ГТО / С.П. Аршинник, Н.А. Амбарцумян, Г.Н. Дудка, К.В. Малашенко, М.Ю. Пушкарный, В.И. Тхорев // Ученые записки университета имени П.Ф. Лесгафта - 2018. - № 5 (159). - С. 22-28.

3. Асачева, Л.Ф. Система занятий по профилактике нарушений осанки и плоскостопия у детей дошкольного возраста. - СПб.: ДЕТСТВО-ПРЕСС, 2013. $-112 \mathrm{c}$.

4. Астафьев В.А. Формирование потребности в самостоятельных занятиях физическими упражнениями в структуре физической культуры личности / В.А. Астафьев, В.В. Борисов //Теория и практика физической культуры. - 2008. - C. 11-15.

5. Бердичевская, Е.М. Медико-биологические основы спортивного отбора и ориентации: учебно-методическое пособие /Е.М. Бердичевская. Краснодар. КГАФК, 2000. - 68 с. 
6. Большая энциклопедия развития и обучения дошкольника: Энцикл. / С.Е. Гаврина, Н.Л. Кутявина, И.Г. Топоркова и др. - Ярославль: Акад. развития, 2008. $-240 \mathrm{c}$.

7. Дворкина Н.И. Влияние спортивных занятий на развитие физических и интеллектуальных способностей дошкольников. /Н.И. Дворкина. Физическая культура: воспитание, образование, тренировка. Москва, 2009. - № 5. С. 22.

8. Коренберг, В.Б. К теории спортивной двигательной активности / В.Б. Коренберг // Теория и практика физической культуры. 2007. №2. - С. 7-11.

9. Крусева, Т.О. Справочник инструктора по физической культуре в детских дошкольных учреждениях / Т.О. Крусева. - Ростов н/Д.: Феникс, 2005. $-253 \mathrm{c}$.

10. Курысь, В.Н. Основы познания физического упражнения: учебное пособие / В.Н. Курысь. - Ставрополь: Изд-во СГУ, 1998. - 130 с.

11. Ланда Б.Х. Физическая подготовленность и физическое развитие обучающихся в построении системы оценки качества образования / Б.Х. Ланда // Теория и практика физической культуры. - 2008. - № 7. - С. 83-87.

12. Лях, В.И. Двигательные способности школьников: Основы теории и методики развития / В.И. Лях. - М.: Терра-Спорт, 2000. - С. 192-193.

13. Матвеев, Л.П. Теория и методика физической культуры (общие основы теории и методики физической воспитания; теоретико-методические аспекты спорта и профессионально-прикладных форм физической культуры: учебник для институтов физической культуры / Л.П. Матвеев. - М.: Физкультура и спорт, 1991. - 573 с.

14. Менхин, Ю.В. К проблеме понимания и формирования двигательного навыка / Ю.В. Менхин // Теория и практика физической культуры. - 2007. №2. C. 12-17.

15. Никитушкин, В.Г. Теория и методика юношеского спорта: учебник / В.Г. Никитушкин. - М.: Физическая культура, 2010. -208 с.

16. Орлов, В.А. Весоростовые характеристики детей школьного возраста с расчетами и оценкой по типологии «Навигатор здоровья» / В.А. Орлов, О.Б. Пирсон А. Школа мгновенной реакции, ловких движений, быстрых ног и сильных рук. Физическое развитие детей 4-5 лет /Пер.с англ. Л.И. Заремской.М.: Астрель: АСТ, 2011. - 320 с.

17. Попкова, Н. В. Индивидуализация процесса физического воспитания детей старшего дошкольного возраста: автореф. дис. ... кандидата педагогических наук. - Челябинск, 2010. - 28 с. 
18. Солодков, А.С. Физиология человека. Общая. Спортивная. Возрастная: учебное пособие / А.С. Солодков, Е.Б. Сологуб. - 3-е изд., исправленное и дополненное. - М.: Олимпия Пресс, 2008. - 620 с.

19. Шебек, В.Н. Физическое воспитание дошкольника / В.Н. Шебек, Н.Н. Ермак, В.А. Шишкина. - М.: Просвещение. 2000. - 258 с.

20. Формирование навыков основных движений у детей дошкольного возраста средствами гимнастики: методические разработки. - М.: ГЦОЛИФК, 1991. - 33c. 
УДК 37.04-053

\title{
ФОРМИРОВАНИЕ САМООЦЕНКИ МЛАДШИХ ШКОЛЬНИКОВ В УЧЕБНО-ВОСПИТАТЕЛЬНОМ ПРОЦЕССЕ
}

\section{Неделько Анна Александровна}

Аннотация: В данной публикации проанализированы виды самооценок, особенности личности учащихся младшего школьного возраста. Даны методические рекомендации учителям по формированию самооценки учащихся в процессе развития функциональной грамотности, через критериальное оценивание, в целостном учебно-воспитательном процессе. Сформулированы выводы по верному исполнению учителем своей важной роли: влияние на становление конкурентноспособной личности в модернизируемом образовании.

Ключевые слова: самооценка, функциональная грамотность, младший школьник, учебно-воспитательный процесс, конкурентноспособная личность, модернизация образования, критериальное оценивание.

\section{FORMATION OF SELF-ESTEEM OF YOUNGER STUDENTS IN THE EDUCATIONAL PROCESS}

\section{Nedelko Anna Alexandrovna}

\begin{abstract}
This publication analyzes the types of self-assessments, personality traits of primary school students. Methodological recommendations are given to teachers on the formation of students ' self-esteem in the process of developing functional literacy, through criteria-based assessment, in a holistic educational process. Conclusions are formulated on the correct performance of the teacher's important role: the impact on the formation of a competitive personality in the modernized education.

Key words: self-assessment, functional literacy, primary school student, educational process, competitive personality, modernization of education, criteriabased assessment.
\end{abstract}


Залогом гармоничного развития личности является адекватная самооценка. Самооценка младшего школьника - это отношение учащегося к самому себе, к своим способностям, субъективным возможностям, чертам характера, личностным качествам, поступкам, созданию себе кумиров. От правильно сформированной самооценки зависят все жизненные достижения, межличностное взаимодействие, успешность в учёбе, оценка объектов социума и отношение к ним. Самооценка может быть: адекватной (объективной), заниженной и завышенной. [1, с. 2]

В каждом возрастном периоде на формирование самооценки преимущественно влияет та деятельность, которая в этом возрасте является ведущей. В младшем школьном возрасте ведущей является учебная деятельность. Именно от её хода и зависит в решающей степени формирование самооценки ребёнка, она прямо связана с его успеваемостью, успехами в учении. Учение, как ведущая деятельность, начинает корректировать формирование личности буквально с первых месяцев прихода ребёнка в школу. Причём психологические исследования показывают, что самооценка младших школьников ещё далеко не самостоятельна, над ней довлеют оценки окружающих, прежде всего оценки учителя. Поэтому, крайне необходимо, вместо привычной пятибалльной системы оценивания результатов деятельности учащихся, внедрять, в учебно-воспитательный процесс, критериальное оценивание. Потому что именно критериальное оценивание, позволяет формировать у учащихся действий самоконтроля и самооценки. Существуют различные техники, формы, методы, приёмы, виды построения учебно-воспитательного процесса, которые помогают учителю в осуществлении непрерывного оценивания деятельности учащихся, предоставлении ученикам включиться в образовательный процесс через самооценивание и взаимооценивание, таким образом, формируя у младших школьников действие контроля. [2, с. 81]

Низкий уровень самооценки учащихся приводит к тревожности, к неуверенности в себе, к снижению учебной мотивации, к нарушениям адаптации в социуме, к появлению комплексов, к непониманию как в коллективе, так и в семье. Эти учащиеся всё время думают, что их обманут, обидят, недооценят, они всегда ожидают худшего, выстраивают вокруг себя оборонительную стену недоверия, стремятся к уединению, обидчивы, нерешительны. При выполнении любого дела настроены на неудачу, находя 
непреодолимые препятствия. Учащиеся с заниженной самооценкой зачастую отказываются от новых видов деятельности из-за страха не справиться, переоценивают достижения своих сверстников и не придают значения собственным успехам.

Заниженная самооценка у учащегося крайне неблагоприятна для полноценного развития личности. У них есть опасность формирования установки: "Я плохой", "Я ничего не могу", "Я неудачник".

Если им предложить проверить свою работу и найти в ней ошибки, они перечитывают работу молча, ничего не меняя, или отказываются её проверять, мотивируя это тем, что всё равно ничего не увидят. Они выбирают только лёгкие, простые задачи, и вполне достижимые, реальные цели, как в учёбе, так и в жизненных ситуациях. Учащиеся, с заниженной самооценкой, словно берегут свой успех, и боясь его потерять, боятся самой деятельности. Неуверенность в себе, у таких учащихся, ярко проявляется в их планах на будущее.

Высокий уровень самооценки приводит к тому, что данные учащиеся всегда переоценивают свои возможности, результаты деятельности, личностные качества. Они выбирают задачи и цели, которые им явно не по силам. После неуспеха продолжают настаивать на своём или тут же переключаются на самую лёгкую задачу или цель, движимые мотивом престижности, чтоб доказать самим себе и окружающим, что они могут справиться. Учащимся, с завышенной самооценкой, необязательно расхваливать себя, они могут охотно критиковать всё и всех, тем самым показывая своё превосходство.

Высокомерие, бестактность, чрезмерная самоуверенность - эти черты личности легко формируются у учащихся с завышенной самооценкой и сопротивляются перестройке. Они склонны сохранять её, игнорируя и оценку его окружающими, и свой собственный опыт. Эти учащиеся не допускают у себя наличие слабости, неумения, несостоятельности, они всегда считают, что они правы. Часто стремятся к управлению другими детьми, видя их слабости, но не видя при этом своих собственных, часто перебивает, относятся к другим свысока, всеми силами стараются обратить на себя внимание. От этих учащихся можно услышать: "Я самый лучший". При всём этом, они могут быть часто агрессивны, принижать достижения своих сверстников. [3, с. 30] 


\section{ТРАДИЦИИ И ИННОВАЦИИ В СОВРЕМЕННОЙ НАУКЕ И ОБРАЗОВАНИИ: ТЕОРИЯ И ПЕРЕДОВАЯ ПРАКТИКА}

Рекомендации для педагогов по формированию адекватной самооценки младшего школьника:

- оценка должна служить главной целью - стимулировать и направлять учебно-познавательную деятельность младшего школьника;

- учитель должен давать содержательную оценку работе младшего школьника;

- оценка должна не завершать учебно-познавательную деятельность, а сопровождать её на всех ступенях;

- в учебной деятельности необходимо сравнивать детей, которые обладают приблизительно одинаковыми способностями, но достигают разных результатов из-за различного отношения к учению;

- необходимо использовать взаимное рецензирование, при этом отмечать достоинства и недостатки, высказывая мнения об оценке;

- после рецензирования работа возвращается автору, и учащиеся самостоятельно анализируют свою работу;

- предлагать ученику с заниженной самооценкой оказывать помощь слабоуспевающему младшему школьнику;

- необходимо включать ситуации, актуализирующие самооценку ребёнка, ставящие перед ним задачу осознания особенности своей работы, её сильных и слабых сторон и способствующих обращенности ребёнка на собственные способы действия;

- необходимо вводить тетради, в которых учащиеся по специальной схеме делают записи, анализируя и оценивая свою работу на уроке, определяя меру усвоения материала, степень его сложности, выделяя наиболее трудные моменты работы;

- необходимо предлагать детям самостоятельно оценивать классные и домашние задания до того, как отдать на проверку учителю, после того как работы проверил и оценил учитель, необходимо обсуждать случаи несовпадения оценок;

- выяснить основания, на которых строят самооценку дети и показатели, по которым оценивает учитель;

- необходимо использовать похвалу в работе с детьми, имеющими заниженную самооценку.

Рекомендуется использование различных видов самопроверки, взаимопроверки, оценочных листов (с конкретными критериями оценивания). $[3$, c. 52] 
Для того, чтобы сформировать объективную (адекватную) самооценку у учащихся младшего школьного возраста, учебно-воспитательный процесс должен реализовываться по программе, содержащей три основных блока:

1) диагностика уровня ЗУН:

- карточки «Лист оценивания» - для самопроверки и взаимопроверки;

- карточки «Найди ошибки» - индивидуально, в паре, в группе;

- рефлексия - «Дерево», «Лесенка», «Смайлы», «Светофор», «Комментарии».

2) организация учебного процесса:

- «Ученические чтения» - высказывание, анализ, рассуждения;

- деление класса на «учитель - ученик» - шефство, контроль, взаимопомощь;

- глубокий анализ и характеристика литературных произведений и персонажей - дебаты, диспуты, дискуссии, анализ.

3) организация воспитательного процесса:

- выставки творческих работ - голосование и обсуждение;

- «Рейтинговые» классные часы - беседы, анализ, подведение итогов, постановка перспективных целей;

- классные часы «Очумелые ручки» - изготовление различных работ по выбору учащихся.

Учителю необходимо готовить приблизительное планирование распределения блоков (программы) по учебным предметам (табл. 1), что позволит структурировано и индивидуально формировать адекватную самооценку у учащихся класса.

\section{Таблица 1}

Распределение блоков программы (на примере 3 четверти 1 класса) по формированию самооценки младших школьников

в процессе развития функциональной грамотности

\begin{tabular}{|l|l|c|c|}
\hline \multicolumn{1}{|c|}{ Предмет } & \multicolumn{1}{|c|}{ Выполняемая работа } & $\begin{array}{c}\text { Количество } \\
\text { часов }\end{array}$ & $\begin{array}{c}\text { Номер } \\
\text { блока }\end{array}$ \\
\hline $\begin{array}{l}\text { обучение } \\
\text { грамоте }\end{array}$ & $\begin{array}{l}\text { оценочные листы, «найди ошибки», рефлексия, } \\
\text { «ученические чтения», «учитель - ученик», } \\
\text { анализ и характеристика литературных } \\
\text { произведений и героев }\end{array}$ & 90 & 1,2 \\
\hline математика & $\begin{array}{l}\text { оценочные листы, «найди ошибки», рефлексия, } \\
\text { «учитель - ученик» }\end{array}$ & 60 & 1,2 \\
\hline
\end{tabular}




\begin{tabular}{|l|l|c|c|}
\hline \hline естествознание & $\begin{array}{l}\text { оценочные листы, рефлексия, «ученические } \\
\text { чтения», «учитель - ученик» }\end{array}$ & 15 & 1,2 \\
\hline познание мира & $\begin{array}{l}\text { оценочные листы, рефлексия, «ученические } \\
\text { чтения», «учитель - ученик» }\end{array}$ & 15 & 1,2 \\
\hline $\begin{array}{l}\text { художественный } \\
\text { труд }\end{array}$ & $\begin{array}{l}\text { рефлексия, «учитель - ученик», выставки } \\
\text { творческих работ }\end{array}$ & 15 & $1,2,3$ \\
\hline классный час & $\begin{array}{l}\text { рефлексия, «ученические чтения», «рейтинги», } \\
\text { «очумелые ручки» }\end{array}$ & 15 & $1,2,3$ \\
\hline
\end{tabular}

Чтобы учителю добиться положительной динамики, следует учитывать необходимость работы над формированием самооценки младших школьников: регулярно, систематически, на каждом занятии.

Далее предоставлен ряд некоторых фрагментов уроков и классных часов, как элементы цельного учебно-воспитательного процесса.

Предмет: обучение грамоте (русский язык и литературное чтение).

1. Сказка «Волк и семеро козлят» Братья Гримм.

Сейчас мы прочитаем сказку «Волк и семеро козлят» по цепочке, по одному предложению. После прочтения, мы обсудим данную сказку, поговорим о прочитанном.

Вопросы для обсуждения:

- правильно ли поступала коза, что оставляла козлят одних дома?

- могла ли предотвратить мать потерю своих деток?

- хорошо ли коза поступила с волком?

- дайте свою оценку предложению: «И стали они жить-поживать попрежнему».

- верно ли поступили козлята, что открыли дверь?

- спрятавшийся козлёнок честно ли поступил по отношению к сложившейся ситуации? Как бы вы поступили на его месте?

- верно ли высказывание - «кузнец во всём виноват!»?

- правильно ли поступил волк по отношению к козлятам? К козе?

- с каким умыслом (для чего) волк вернулся в дом к козе и почему он пригласил её погулять в лес?

- вы бы тоже спокойно разговаривали бы со своим врагом и пошли бы с ним куда-либо (как поступила коза)?

- почему коза пошла с волком?

- когда коза пошла с волком в лес, она своего козлёнка опять оставила дома? Выскажите своё мнение. 
- почему коза не смогла спасти (уберечь) своих козлят, когда уже было одно предупреждение, что приходил волк?

- почему козлята не погибли в животе у волка, в костре?

- что и как вы бы изменили в этой сказке?

- каким бы вы хотели побывать персонажем из этой сказки?

- заботливой мамой была коза?

- кто оказался хитрее: волк, коза или козлёнок?

К каким выводам мы пришли? Как необходимо себя вести, чтобы не попасть в неприятные ситуации? Нарисуйте героя сказки, который вам более понравился и объясните: чем он вам понравился.

2. Имя существительное.

Давайте вспомним - что такое «имя существительное»? Какие признаки имеет имя существительное? Какие признаки имени существительного относятся к постоянным и непостоянным? У вас на партах карточки. Заполните данную таблицу, после чего мы проверим на сколько хорошо вы усвоили материал.

Выполни задание (заполни таблицу).

\begin{tabular}{|l|l|l|}
\hline \multicolumn{1}{|c|}{ Имя существительное } & Постоянные признаки & Непостоянные признаки \\
\hline очки & & \\
\hline юбка & & \\
\hline солнце & & \\
\hline брюки & & \\
\hline воробей & & \\
\hline
\end{tabular}

Оцени себя сам:

Оценка одноклассника:

Проверка родителями:

Проверка учителем:

Комментарий учителя:

Критерии оценивания: нет ошибок и исправлений - красное солнышко (5 баллов), одна ошибка (+ 1 исправление) или два исправления - жёлтое солнышко (4 балла), две и более ошибок или три и более исправлений - звезда (необходимо повторить пройденный материал об имени существительном). 
3. Алфавит. Звуки и буквы.

Ответьте мне, пожалуйста, на вопросы:

- что такое алфавит?

- сколько букв в русском алфавите?

- сколько гласных букв? Согласных? Какие буквы не относятся ни к гласным, ни к согласным?

- что вы знаете о йотированных буквах?

- чем отличаются буквы от звуков?

- что вы знаете о гласных и согласных звуках?

- как определить сколько слогов в слове?

- как правильно указать ударный слог?

Молодцы, ребята. Мы вспомнили и повторили всё, что знаем о звуках и буквах. Я думаю, вам не составит труда проверить работу ученика, который выполнил задание по нашей сегодняшней теме. У вас на партах находится карточка с выполненной работой. Ваша задача: написать комментарий, что необходимо повторить этому ученику, чтобы в дальнейшем не возникали подобные ошибки.

Найдите ошибки (работа в паре).

Яхта - 1 слог, 4 буквы, 4 звука; мальчик - 3 слога, 7 букв, 6 звуков; перья - 1 слог, 4 буквы, 4 звука; горох - 3 слога, 5 букв, 4 звука.

Отдайте карточку «соседней паре». Приклейте стикер со своим комментарием о работе одноклассников.

4. Перенос слов.

Давайте с вами вспомним правила переноса слов. Повернитесь друг к другу и по очереди расскажите правила переноса. Оцените друг друга на стикерах (это могут быть: комментарии, смайлы, эмблемы (значки), и так далее). После проверки: похлопают те, у кого нет замечаний; похлопают те, кому необходимо ещё подучить правила; теперь я похлопаю вам, какие вы у меня молодцы. Учите и повторяйте правила, чтобы грамотно писать.

Предмет: математика.

1. Компоненты сложения и вычитания.

Давайте с вами вспомним компоненты сложения. (слагаемое, слагаемое, значение суммы)

Как называются компоненты вычитания? (уменьшаемое, вычитаемое, значение разности) 
Как найти неизвестное слагаемое? (из значения суммы вычесть известное слагаемое)

Как найти уменьшаемое? (к значению разности прибавить вычитаемое)

Как найти неизвестное вычитаемое? (из уменьшаемого вычесть значение разности)

Хорошо. Молодцы. Поднимите большой палец вверх те, кто хорошо знает ответы на все предыдущие вопросы. Как вы думаете: какая тема нашего урока?

Наклейте стикеры на наше дерево с пожеланиями для самого себя на сегодняшний урок.

Найдите на парте карточку. Подставьте неизвестные компоненты в выражения. Отдайте выполненное задание на проверку соседу по варианту. Давайте обозначим критерии оценивания. Перед нами 10 выражений на 10 баллов. Значит, нам необходимо, выполнить верно хотя бы (5 - 6) выражений, чтобы получить - хорошо. Сколько баллов необходимо набрать на «отлично» и «молодец»? (7 - 8, 9 - 10) А кто получит менее 5 баллов? («старайся», «повтори») Молодцы. Приступаем. На выполнение работы - 10 минут.

\begin{tabular}{|l|l|}
\hline $3+\ldots=8$ & $2+\ldots=3$ \\
\hline${ }_{-}-2=5$ & ${ }_{-}-5=1$ \\
\hline $8+\ldots=9$ & $4+\ldots=7$ \\
\hline${ }_{-} 4=6$ & ${ }_{-}-7=2$ \\
\hline $1+\ldots=4$ & $4+\ldots=10$ \\
\hline
\end{tabular}

Я считаю, что у меня баллов. Моя отметка:

Я считаю, что у тебя баллов. Твоя отметка:

Оценили? Теперь посмотрите на доску. Проверьте. Поаплодируйте себе и другим, кто выполнил и проверил верно. Что мы посоветуем тем, у кого ошибки? (хором: «правила ты повторяй, и на деле применяй!»)

Предмет: естествознание.

1. Что такое естественные источники звука? Что такое искусственные источники звука?

Ребята, вы сейчас будете, по одному, подходить ко мне и вытаскивать из мешка бумажный квадрат. Идёте в ту группу, которая по цвету подходит вашему квадрату. Получилось 4 команды. Итак, давайте вспомним правила работы в команде. У каждой группы имеется оценочный лист урока. Ваша 
задача: в конце урока сдать мне эти листы в заполненном виде (с комментариями, стикерами, рисунками, значками - для своей команды и для других команд).

\begin{tabular}{|l|l|l|}
\hline \multicolumn{1}{|c|}{ Задание урока } & Для нашей команды & Для других команд \\
\hline $\begin{array}{l}\text { Однажды пропали искусственные } \\
\text { источники звука... }\end{array}$ & & \\
\hline $\begin{array}{l}\text { Однажды пропали естественные } \\
\text { источники звука... }\end{array}$ & & \\
\hline Проведём эксперимент... & & \\
\hline Расскажем, что знаем... & & \\
\hline
\end{tabular}

Давайте отметим на «дереве» и на «лесенке» наши достижения, наше настроение, наши советы и пожелания.

Предмет: познание мира.

1. Вкусно и полезно.

Давайте с вами вспомним: какие продукты питания производятся в нашей стране? (ответы учеников, прикрепляю названия продуктов на доску) Сейчас вы будете подходить к доске, снимать с доски название продукта и рассказывать о пользе данного продукта питания. Со своим «продуктом» садитесь на своё место и составляйте рассказ: «Как я ем...», «Что я ем...», «Однажды я съел...», то есть рассказ о продукте питания может содержать информацию: когда вы познакомились с этим продуктом, ваше личное отношение к данному продукту, когда и как вы его едите, любит ли ваша семья этот продукт, и так далее. Можете подготовить иллюстрацию (по желанию).

2. Вкусно и полезно.

На прошлом уроке мы с вами говорили о продуктах питания, которые производят в нашей стране. Мы вспоминали о пользе данных продуктов питания и каждый из вас рассказал нам о том, как вы и ваши члены семьи относятся к тому или иному продукту, как часто употребляете его, чем он вам нравится. Сегодня у нас продолжение данной темы, но мы уже будем говорить о... попробуйте сами поставить цель урока, после прослушивания стихотворения. 
Надо кушать: помидоры,

Фрукты, овощи, лимоны,

Кашу - утром, суп - в обед,

А, на ужин, - винегрет.

Ну, а, если ты свой день

Начнёшь со сладкого, с конфет,

И фастфудом их заешь,

Газировкой всё запьёшь,

То, тогда, наверняка,

Ваши спутники всегда

Будут: вялость, бледный вид,

Зубы и живот болит,

И неважный аппетит.

Верно, сегодня мы поговорим о вредной пище. Но, для начала, вспомним о правилах соблюдения гигиены и техники безопасности на кухне. Сейчас мы с вами встанем в круг, возьмите с собой стикер с пожеланием на урок, для самого себя, или для одноклассников. Рассказываем правило гигиены или безопасности, озвучиваем пожелание и приклеиваем на доску. А в конце урока, вы наклеите слова благодарности, пожелания для следующего урока, достигнуты ли цели пройденного урока, что бы вы хотели ещё узнать, и так далее.

3. Суммативное оценивание по разделу.

У вас на партах проверочная работа. Посмотрите внимательно на задания, на дескрипторы и критерии оценивания. Какие ваши цели? (внимательно всё прочесть, хорошо подумать, верно выполнить задания)

Молодцы. Желаю успехов. Приступаем.

Оценочный лист:

\begin{tabular}{|l|l|c|}
\hline \multicolumn{1}{|c|}{ Критерий оценивания } & \multicolumn{1}{|c|}{ Дескриптор } & Балл \\
\hline \multirow{2}{*}{$\begin{array}{l}\text { определяет полезную и } \\
\text { вредню пищу }\end{array}$} & $\begin{array}{l}\text { находит и отмечает картинки и названия } \\
\text { полезных продуктов питания }\end{array}$ & 5 \\
\cline { 2 - 3 } & $\begin{array}{l}\text { находит и отмечает картинки и названия вредных } \\
\text { продуктов питания }\end{array}$ & 5 \\
\hline $\begin{array}{l}\text { обладает знаниями о режиме } \\
\text { питания, гигиене и технике } \\
\text { безопасности на кухне }\end{array}$ & $\begin{array}{l}\text { находит и зачёркивает лишнее высказывание } \\
\text { (совет/предложение), которое не относится к } \\
\text { верному соблюдению режима питания }\end{array}$ & 1 \\
\hline
\end{tabular}




\section{ТРАДИЦИИ И ИННОВАЦИИ В СОВРЕМЕННОЙ НАУКЕ И ОБРАЗОВАНИИ: ТЕОРИЯ И ПЕРЕДОВАЯ ПРАКТИКА}

\begin{tabular}{|c|c|c|}
\hline & $\begin{array}{l}\text { находит и зачёркивает лишнее высказывание } \\
\text { (совет/предложение), которое не относится к } \\
\text { верному соблюдению гигиены питания }\end{array}$ & 1 \\
\hline & $\begin{array}{l}\text { находит и зачёркивает лишнее высказывание } \\
\text { (совет/предложение), которое не относится к } \\
\text { верному соблюдению техники безопасности во } \\
\text { время приготовления и употребления еды }\end{array}$ & 1 \\
\hline $\begin{array}{l}\text { определяет продукты } \\
\text { питания, производимые в } \\
\text { Казахстане }\end{array}$ & $\begin{array}{l}\text { указывает продукты питания, производимые в } \\
\text { Казахстане }\end{array}$ & 4 \\
\hline
\end{tabular}

Твои баллы: из 17

Комментарий учителя:

Выводы ученика после оценивания:

Предмет: художественный труд (изобразительное искусство и трудовое обучение).

1. Пейзаж моего города.

Подготовьте свои выполненные работы для выставки. Сейчас мы проведём голосование с комментариями и выводами.

Итак, каждый из вас, по 4 человека, будут подходить к нашей оформленной выставке, оставлять свой голос стикером, комментировать: «Я отлаю свой голос за эту работу, потому что...». После завершения голосования, каждый из вас, будет высказывать своё мнение о собственной работе: «Мне удалось...», «Мне не удалось...», «Буду стараться...», «Мне надо научиться...», «Мне интересно узнать...», и так далее.

2. Сказочные герои.

Вспоминаем технику безопасности и правила работы с пластилином. Рассаживаемся в произвольные пары, по желанию, можно сесть со своим наставником («учитель - ученик»). Работа выполняется в парах, поэтому вспоминаем правила работы, и поведения, в группах.

После завершения работы, выходим к доске и рассказываем: почему вы выбрали данного (или данных персонажей), из какого произведения он (или они), как вы его (или их) создавали.

После выступления каждой пары мы будем аплодировать. Если кто-то захочет прокомментировать работу или выступление, мы дадим возможность высказаться. 
Предмет: классный час (проводится раз в неделю, а также по необходимости (тематические классные часы)).

1. Итоги недели «Наши достижения».

Приготовьте, пожалуйста, стикеры с анализом своих успехов и неудач, по итогам недели. Можно выразить свои мысли схематично. Сейчас каждый из вас будет подходить к «Лестнице успехов», снимать свои стикеры за прошлую неделю и приклеивать новые стикеры, за эту неделю. Обязательно с комментариями и рассуждениями.

- Каких успехов вы достигли?

- Что у вас стало получаться лучше?

- Что ещё не получается?

- Какие обстоятельства мешают вам достичь желаемого?

- Кто вам помогает в достижении ваших целей?

- Какие перспективные цели вы желаете достичь на следующей неделе?

- Какие необходимо приложить усилия для достижения данных целей?

Сделайте вывод по «лестнице» - поднимаетесь или опускаетесь вы по ней? Проанализируйте, пожалуйста, причину движения по ней.

2. Итоги недели «Актив класса».

Посмотрите на доску. На доске ваши имена. Ваша задача: подойти к надписи своего имени, снять табличку с доски, и сказать - какую обязанность вы выполняли на неделе. Дать характеристику своей выполненной работе.

Затем будет голосование аплодисментами всего класса: «отлично справился» / «не справился». Проанализируем причину (высказываются все желающие).

3. Итоги недели «Наставники».

Рассаживаемся по группам «учитель - ученик». У вас на партах лежат таблицы, которые необходимо заполнить. Затем, после заполнения, будем обсуждать устно.

Сегодня вы поменяетесь должностями: те, кто был «учителем» - станет «учеником», кто был «учеником» - станет «учителем».

Комментарии, в таблицах, можно заполнять: цветными карандашами («светофор»: красный - плохо, жёлтый - старайся, зелёный - молодец); приклеивать стикеры; писать пожелания, замечания, предложения; рисовать символы, эмблемы, значки. Ваша цель: дать характеристику как собственной работе, так и работе своего напарника. 
Давайте вспомним, в чём заключаются обязанности «учителя» и «ученика». (ответы учащихся: помогать, советовать, напоминать, проверять, объяснять, слушать, учить, делать замечания, выполнять, и так далее)

\begin{tabular}{|c|c|c|c|}
\hline Имя «учителя» & $\begin{array}{c}\text { Комментарий от } \\
\text { «учителя» о } \\
\text { собственной работе }\end{array}$ & $\begin{array}{c}\text { Имя «ученика» } \\
\text { Комментарий от } \\
\text { «ученика» о } \\
\text { собственной работе }\end{array}$ \\
\hline & & & \\
\hline
\end{tabular}

\begin{tabular}{|c|c|c|c|}
\hline Имя «учителя» & $\begin{array}{c}\text { Комментарий от } \\
\text { «ученика» о работе } \\
\text { «учителя» }\end{array}$ & $\begin{array}{c}\text { Имя «ученика» } \\
\text { Комментарий от } \\
\text { «учителя» о работе } \\
\text { «ученика» }\end{array}$ \\
\hline & & & \\
\hline
\end{tabular}

Исходя из вышеизложенного, следует сделать вывод: сегодняшнее образование направлено на развитие рефлексии и самооценки степени сформированности функциональной грамотности, и личности в целом.

Используя в учебно-воспитательном процессе предложенные выше формы и методы оценивания, методические рекомендации для организации практико-ориентированного обучения, имеется возможность оказать продуктивное, всестороннее, целостное воздействие на формирование самооценки младших школьников.

\section{Список литературы}

1. Максимова Л.А., Андросова М. И. Формирование учебной мотивации у младших школьников // Научно-методический электронный журнал «Концепт». - 2017.

2. Аспер К. Внутренний ребёнок и самооценка [Текст] / К. Аспер. - М.: Добросвет, 2008.

3. Феннел М. Как повысить самооценку / Мелани Феннел; пер. с англ. А.С. Марушкиной, Е.Ю. Терентьевой. - М.: Астрель: АСТ, 2007. 
ГЛАВА ІІ.

ФУНКЦИОНАЛЬНЫЕ АСПЕКТЫ ЯЗЫКА: ПРОШЛОЕ И НАСТОЯЩЕЕ

\title{
УДК 811.161.1
}

\section{ПОЛИТИЧЕСКИЙ ЯЗЫК СОВРЕМЕННОЙ ЭПОХИ: К ПРОБЛЕМЕ ОПИСАНИЯ ИННОВАЦИЙ}

\begin{abstract}
Заварзина Галина Анатольевна доктор филологических наук, доцент, заведующий кафедрой русского языка, современной русской и зарубежной литературы Воронежский государственный педагогический университет (ВГПУ)
\end{abstract}

Аннотация: Настоящее исследование посвящено описанию особенностей развития российского политического языка в XXI веке и проведено на новейшем лексико-фразеологическом материале. В работе детальному анализу подверглись динамические изменения современного политического словаря, нашедшие отражение в появлении разного рода инноваций. Установлено, что заимствование, морфологическое словообразование и семантические трансформации - это наиболее значимые направления расширения словарного состава политического языка, обусловленные внелингвистическими и собственно лингвистическими причинами.

Ключевые слова: политический язык, политическая лексика и фразеология, заимствование, морфологические неологизмы, семантические инновации.

\section{THE POLITICAL LANGUAGE OF THE MODERN ERA: ON THE PROBLEM OF DESCRIBING INNOVATIONS}

\section{Zavarzina G.A.}

Abstract: The present study is devoted to the description of the features of the development of the Russian political language in the XXI century and is based on the 
latest lexical and phraseological material. The paper analyzes in detail the dynamic changes in the modern political vocabulary, which are reflected in the emergence of various kinds of innovations. It is established that borrowing, morphological word formation and semantic transformations are the most significant directions of expanding the vocabulary of a political language, due to non-linguistic and linguistic reasons.

Key words: political language, political vocabulary and phraseology, borrowings, morphological neologisms, semantic innovations.

Проблема изменений в качественно-количественном составе политической лексики и фразеологии приобрела особую актуальность на рубеже XX - XXI вв. Современный этап развития российского общества характеризуется значительными переменами во всех сферах общественнополитической жизни, которые оказывают безусловное влияние на современную языковую ситуацию, отличительной чертой которой является необычайный динамизм изменений, выявляющихся на разных уровнях структуры языка.

Как известно, к влиянию социальных факторов в наибольшей степени восприимчива лексико-семантическая система языка, прежде всего, область политической лексики, которая в периоды социальных потрясений подвергается наиболее существенным трансформациям.

Одной из закономерностей развития словарного состава языка является его расширение за счет разного рода инноваций, которое идет, как известно, несколькими путями, самыми важными из которых являются заимствование, морфологическое словообразование и семантические трансформации.

Как показывают исследования, политический словарь русского языка новейшего периода активно пополняется иноязычными заимствованиями (в основном, американизмами английского происхождения). Отмеченная особенность, по мнению В.Г. Костомарова, является одной из примет «языкового вкуса эпохи» [1, c.142-143] и обусловлена как экстралингвистическими, так и лингвистическими причинами.

К основным экстралингвистическим причинам традиционно относят «...наличие более или менее тесных экономико-промышленных, политических и культурных связей между народами-носителями языка» [2, с.13]. Ср. также высказывание И.А. Стернина: «Условиями активизации процессов заимствования выступают развивающиеся контакты между народами, 
расширяющееся двуязычие, формирование открытого общества, развитие международного сотрудничества и кооперации» [3, с.25-26]. Русский язык в процессе своего развития испытывал огромное влияние самых разных языков (известно северное, т.н. варяжское влияние, греческо-византийское, тюркское, польское, немецкое, французское, теперь - американское), смело вступал в контакты с другими языками, всегда был открыт для заимствований. Однако на рубеже XX - XXI века иностранное слово стало не только необходимым, нужным (когда есть потребность в наименовании новой реалии, замене длинного оборота или вуалировании негативного смысла понятия), но и привлекательным, престижным, модным (как, скажем, церковная лексика в силу вошедшей в моду «религиозности»). Как отмечал Л.П. Крысин, «вследствие иноязычности формы, смысл чужого слова для многих говорящих нередко оказывается непонятным; в то же время эта непонятность служит символом недоступной учености, почему и речь, содержащая иноязычные слова, часто расценивается как социально престижная» [4, с. 11-12]. По справедливому замечанию Н.С. Валгиной, современная тяга к заимствованиям нередко обусловлена т.н. «американоманией, когда привлекательными оказываются не только технические новшества, но и стандарты жизненного уровня, манера поведения и общения, вкусы» [5, с. 108]. В таких случаях мера и избирательность в применении иноязычной лексики начинает утрачиваться (ср.: консенсус - согласие, легитимный - законный, стагнация - застой, бизнесмен - предприниматель). Об этом свидетельствует современная тенденция к использованию вместо русского слова - иноязычного, нередко приводящая к «информационной опустошенности высказываний и, следовательно, к полной бесполезности самих иноязычных слов, которые затуманивают смысл речевых произведений или даже искажают его» [6].

Среди лингвистических причин заимствования политических словесных знаков можно отметить потребность в наименовании нового явления для заполнения денотативных лакун (ср., напр., омбудсмен/омбудсман в значении «уполномоченный по правам человека») или в специализации понятия (ср., напр., слово электорат в значении «круг избирателей, голосующих за кандидатов тех или иных политических партий или за независимых кандидатов на выборах всех уровней», вытеснившее словесный знак «избиратели»; ср. также легитимный в значении «поддерживаемый большинством политически активного населения»). 
При этом большинство иноязычных слов обозначают реалии и понятия, давно известные на Западе и начинающие завоевывать право на жизнь в новой российской действительности (напр., хардлайнер, скинхэды, олигополизм, популизм и др.). Другая группа заимствований обозначает явления, известные у нас, но не имеющие однословных обозначений р.: саммит, истеблишмент, маргинал, спикер, инаугурация, спичрайтер и др. Потребность в подобных иноязычных лексемах обусловлена действующим в языке законом экономии, побуждающим заменять длинные наименования на более короткие в случае повышения частотности их употребления.

Безусловно, многие иноязычные слова, широко употребляющиеся в современной русской речи, не являются принципиально новыми, а были известны русскому языку и ранее, но оказались востребованными лишь в последнее время. Названные слова перестают обозначать понятия, свойственные зарубежной или дореволюционной действительности, и начинают употребляться для номинации понятий новой российской действительности.

Так, например, слово олигарх, знакомое советским людям по учебникам истории древнего мира (ср.: спартанский олигархический союз) и произведениям классиков марксизма- ленинизма (ср.: финансовая олигархия), в настоящее время обозначает крупных отечественных капиталистов, имеющих большое личное влияние на политический процесс (в первую очередь, владельцев мажоритарных пакетов акций крупных средств массовой информации). Ср. также современное толкование и употребление слов спикер, мэр, префект, полиция, в значениях которых произошла утрата смысловых компонентов «в зарубежных // буржуазных // некоторых странах».

Следует отметить также, что в последние десятилетия в русском языке актуализировались некоторые экзотические лексемы, связанные с обозначением мусульманских социально-политических группировок, сословий (ср.: моджахеды, талибь, джихад, шахид, интифада, шариат, ваххабизм и др.).

Морфологическое словообразование, обусловившее номинативный взрыв начала XXI века, весьма активно проявляет себя в процессе производство новых политических лексем. Наиболее частотными способами словообразования в русском языке новейшей эпохи являются способы 
аффиксации и сложения. Первый выступает в виде префиксации, суффиксации и суффиксально-префиксального способа.

В настоящее время активизируются, прежде всего, префиксы, которые передают социально значимую семантику, как-то: временные отношения (ср.: постковидный, послекризисный и др.), отношения отрицания или противодействия (ср.: антиполпредовский, антиправительственный, контртеррористический, непарламентский, неконституционный и др.), отношения поддержки (ср.: прокремлевский, пропрезидентский, пропутинский и др.), отношения неистинности, ложности (ср.: nсевдосуверенитет, квазипарламентаризм, лжекоалиция и др.), отношения интенсификации, высокой степени чего-либо (ср.: суперэлитный, сверхдержава, сверхдоходы, сверхприбыль, гиперинфляция и др.), отношения между общественными группами или лицами (ср.: межведомственный, межпарламентский, межсракиионный и др.), значение утраты того или иного признака (ср.: эксгубернатор, экс-президент, экс-глава, экс-депутат, экс-спикер и др.).

Достаточно активно в процессе образования политических неологизмов также участвуют иноязычные суффиксы (ср.: балканизация, румынизация, вестернизачия, глобализаџия, карнавализация, американизировать, иахидизм, коммунитарность, легитимность, альтернативность, коридорность в значении «характер поведения и качество рабочих решений, определяемы ориентацией на настроения и атмосферу в коридорах власти», карманность в значении «послушное выполнение чужой воли вследствие зависимости в политическом или ином отношении» и др.).

Следует отметить особенную активность образования слов со значением «лицо по принадлежности к организации, партии или другой политической группировке» с суффиксами -ец / - овец: омоновеи, росгвардееи, фондовеи, кремлевец и др. В данной группе слов встречаются также новообразования с общим значением «последователь кого-, сторонник чего-либо», образованные, как правило, от производящих основ- имен собственных или аббревиатур (ср.: путинеи, зюгановеи, УБОПовеи, МЧСовеи и др.). Суффикс -ист является частотным в образовании словесных знаков с общим значением «лицо, характеризующееся свойствами, взглядами, идейным направлением, которые названы мотивирующим словом»: антиглобалист, сепаратист, федералист, фундаменталист, этноцентрист, гэбист и др. Очевидно, что названный 


\section{ТРАДИЦИИ И ИННОВАЦИИ В СОВРЕМЕННОЙ НАУКЕ И ОБРАЗОВАНИИ: ТЕОРИЯ И ПЕРЕДОВАЯ ПРАКТИКА}

суффикс активно участвует в образовании новых слов от заимствованных основ.

Отдельные политические словесные знаки образованы семантикосинтаксическим способом свертывания наименований с добавлением суффиксов -щик, -ик, -ник. При этом суффикс-щик участвует в производстве существительных, обозначающих лицо по принадлежности к организации, учреждению: альтернативщик, антикриминальщ̧ик, оборонщзик и др. Как видно, подобные наименования являются функционально-стилистически и экспрессивно-стилистически окрашенными (ср.: номенклатурщзик - разг; неодобрит.; номенклатурный работник). Интересные группы представляют образования с нулевым суффиксом (ср.: нелегал, федерал, регионал, муниципал и др.), с суффиксами -ик /-ник (ср.: налоговик, силовик, теневик, инициативник, ФСБиник, ГИБДДиник), -ант (ср.: подписант и др.), - арий (ср.: парламентарий, мандатарий, аграрий, миноритарий и др.). Ср. также усеченный словесный знак: наци - национал-патриот и др.

Активизация появления сложных и сложносокращенных слов может рассматриваться как одна из примет русского языка новейшей эпохи.

Новые политические аббревиатуры активно используются современными российскими средствами массовой информации для следующих целей:

1) для наименования новых явлений или понятий, возникших в общественно-политической жизни современной России:

а) органов государственной власти (напр., ОМОН - отряд милиции особого назначения, спецназ, УБОП - Управление по борьбе с организованной преступностью, МЧС - Министерство по чрезвычайным ситуациям, ОБЭП Отдел по борьбе с экономическими преступлениями, ОМО - отдельный милицейский отряд, ППС - патрульно-постовая служба, СОБР - специальный отряд быстрого реагирования, ГНР - группа немедленного реагирования, УОП - Управление по охране порядка, МЧС - Министерство по чрезвычайным ситуациям, КС - Конституционный суд, госаппарат, центризбирком, облдума, нардеп и др.);

б) форм организации власти (напр., СНГ - Содружество независимых государств, СФ - Совет Федерации, РФ - Российская Федерация, МБ Министерство безопасности и МГБ - Министерство государственной безопасности, КУГИ - Комитет по управлению городским имуществом, ГБ Государственная безопасность, ФСО - Федеральная служба охраны, 
отвечающая за безопасность президента и его окружения, ФЭП - Фонд эффективной политики и др.);

в) политических методов, действий или приемов (напр., политкорректность, политтехнолог, теракт, натомания, оргпреступность, МРОТ и др.);

г) политических партий и организаций (напр., АПР - Аграрная партия России, РОПП - Российская объединенная промышленная партия, ДПР Демократическая партия России, РСПП - Российский союз промышленников и предпринимателей, СПС - Союз правых сил и др.);

д) организаций, относящихся к внешнеполитической жизни России (напр., ОБСЕ - Организация безопасности и сотрудничества в Европе, ПАСЕ Парламентская Ассамблея Совета Европы, ЕС - Европейский Союз и ЕС Европейское сообщество, ГУУАМ - Грузия, Украина, Узбекистан, Азербайджан, Молдова, ТНК - транснациональные корпорации, ЕВРАЗЭС Европейско-азиатский экономический союз, СРБ - Союз России и Белоруссии, КЮТО - Комиссия для стран южной части Тихого океана и др.);

2) для фиксирования частичного изменения политического понятия или представления о них (напр., ГИБДД вместо ГАИ, ФСБ вместо КГБ);

3 ) для создания иронического или комического эффекта (напр., «госкомдурь» в значении «Государственный комитет РФ по противодействию незаконному обороту наркотических средств и психотропных веществ» и др.) [7]. Специфика подобных аббревиатур определяется значением тех слов несокращенного словосочетания, семантика которых сталкивается или понимается в разных планах: в общепринятом и в метафорическом, остром, намекающем на какие-либо скрытые и важные обстоятельства. Известно, что комический эффект может возникать в результате сокращения свободных словосочетаний, бытующих в языке или специально придуманных в стилистических целях, имеющих самостоятельное каламбурное, насмешливое, пренебрежительное или комическое значение.

Новые аббревиатуры политической тематики, функционирующие в современных российских СМИ, могут быть представлены

- аббревиатурами «инициального» типа, среди которых выделяются буквенные (напр., ГД, КПРФ, ЛДПР, ВТО и др.) и звуковые (напр., ГУЮ, РОПП, ГРУ, БРИКС и др.);

- слоговыми аббревиатурами, состоящими из начальных частей слов (напр., полпред - полномочный представитель президента, избирком 126 
избирательный комитет, спецназ - специальное назначение, сексот - секретный сотрудник, нардеп, центризбирком и др.);

- аббревиатурами, состоящими из начальной части слова и целого слова (напр., политкорректность, Госдума, демблок, комфракция, госбезопасность, политдвижение, биотерроризм, киберпреступность и др.);

- аббревиатурами смешанного типа, состоящими как из начальных частей слов, так и из начальных звуков (напр., Барс - Банк развития собственности; ЗакС - Законодательное собрание и др.).

Особый интерес, на наш взгляд, представляют аббревиатуры, образованные от имен собственных политических деятелей. Ср.: ДАМ Дмитрий Анатольевич Медведев («Для всех, наверное, стало неожиданностью, что на выборах победил не Жириновский, не Зюганов и не Богданов, а Медведев (в простонародье «ДАМ») - журнал «LITEHOUSE»); ВэВэ - Путин Владимир Владимирович; ВВ, ВВЖ - Жириновский Владимир Вольфович, глава ЛДПР («Пусть хоть сусликом называют, - сообщил в интервью ВВЖ.- Я про себя уже наслушался». - газета «Московский комсомолец»); АБЧ - Чубайс Анатолий Борисович, председатель правления РАО «ЕЭС России» («АБЧ - это «Великий приватизатор», как его называют друзья, или «Великий ваучеризатор», как утверждает оппоненты, объясняет россиянам, чем будет заниматься новый зам». - газета московский комсомолец»).

Следует отметить, что столкновение обычных аббревиатур или аббревиатур, образованных от имен собственных, с аббревиатурой-омонимом может способствовать созданию комического эффекта, порождать каламбур, шутку. Ср.: ВВП - Владимир Владимирович Путин («Что подарят ВВП на юбилей?» - газета «Аргументы и факты») и ВВП - валовая внутренняя продукция («С нынешних 7 \% ВВП отечественный автопром опустился до 3-4 \%. - газета «Комсомольская правда»); БМП - группа предпринимателей С. Богданчикова («Роснефть»), А. Миллера (РАO «Газпром»), С. Пугачева (сенатор от Тувы) («В настоящее время глава «Роснефти» воспринимается как неотъемлемая часть так называемой группы БМП - Богданчиков - Миллер Пугачев. При том что лично Богданчиков подчеркнуто не вмешивается в политические процессы, «фактор БМП» оказывает большое влияние на текущие проекты «Роснефти» - газета «Известия») и БМП - бронетанковая машина пехоты; ср. также: МИФ - Международный инвестиционный фонд и миф - древнее народное сказание; недостоверный рассказ, выдумка. 
Комическое осмысление также может основываться на восприятии обычного слова как аббревиатуры и наоборот. Ср.: ГУАМ (ГУУАМ) - название альянса государств СНГ: Грузии, Украины, Узбекистана, Азербайджана, Молдовы, созданного по инициативе США и Турции с целью ослабления влияния России на постсоветском пространстве («Президенты пяти стран договорились о том, что ГУУАМ будет функционировать не в рамках существующего в СНГ Экономического союза, а в рамках Совета Евроатлантического партнерства - в экономическом и политическом отношении и программы НАТО - в военном отношении» - газета «Известия») и Гуам - остров в Тихом океане («ГУАМ не отправились на Гуам» - газета «Московский комсомолец»). Ср. также: БОС береговой отряд сопровождения и босс - хозяин, владелец, РОМ - районное отделение милиции и ром - крепкий алкогольный напиток, получаемый из сока сахарного тростника и нек. др.

В особую группу следует выделить каламбурные аббревиатуры, необходимое звучание которых отличается неблагозвучием (ср.: ШИЗО штрафной изолятор, БДИПЧ - бюро по демократическим институтам и правам человека, ПБОЮЛ - предприниматель без образования юридического лица) или приводит к нежелательным с точки зрения языковых/этических/эстетических норм ассоциациям (ср.: ЧОП - частное охранное предприятие, ГНИ - Государственная налоговая инспекция и др.).

Безусловно, создание аббревиатурных наименований в языке политики способствует увеличению языкового кода и даёт огромную экономию на уровне текста. Особенно ярко отмеченное явление обнаруживается при сопоставлении аббревиатур с многословными названиями партийных и государственных организаций. Многие из аббревиатурных образований (типа $\mathrm{OMOH}$, бомж, ГИБДД, спецназ) за счет грамматикализации получили закрепление в лексикографических изданиях современного русского языка. Вместе с тем, в настоящее время существуют неудобные в орфоэпическом смысле (типа ГИБДД), неблагозвучные (типа ГУЮ) и этически/эстетически неправомерные (типа ЕБН) аббревиатуры, которые, на наш взгляд, не должны восприниматься как нормативные. Это касается, в первую очередь, тех аббревиатурных номинаций, которые претендуют на терминологическое закрепление в научном языке или в официально-деловом общении (напр., ЗАТО - закрытое административно-территориальное образование и др.).

Как отмечают исследователи, высокой словообразовательной активностью в настоящее время обладают также компоненты гос- (напр., 
госдума, госимущество, госсобственность, госфункиионер, госноменклатура, госбезопасность и др.), евро- (напр., евродепутаты, Европарламент, евроинтеграция, еврозона, еврозаём, еврорегион, евростандарт, Евросоюз и др.), а также -мания (напр., евромания, путиномания и др.) и -гейт (со значением «скандал, связанный с каким-либо лицом или государством»), который, добавляясь к разным основам, может употребляется в определительном значении и обозначать страну (ирангейт, израильгейт), политическое движение (контрасгейт, дунагейт, тамилгейт), правительство (Кремлегейт), сферу деятельности (космогейт), а также лицо, ставшее виновником скандала (Саакашвилигейт) [1]. Отмеченное явление свидетельствует от том, что, круг основ, вовлекаемых в словообразование по этой модели, практически не ограничен.

Ср. также активизацию образования и употребления словосочетаний с некоторыми опорными лексемами: структуры (властные, коммерческие, криминальные, политические, силовые, теневые, кэптивные, финансовые, банковские), элита (государственная, региональная, политическая), зарубежье (ближнее, дальнее), сектор (государственный, частный, теневой, криминальный, акционерный, фермерский и т.д.), рынок (национальный, валютный, форвардный, фондовый, фьючерсный, потребительский, общий, вторичный), управление (государственное, рыночное, менеджеральное).

Семантические неологизмы образуются, как правило, за счет возникновения новых значений в семантической структуре словесных знаков (ср.: регионал в значении «член депутатской группы «Российские регионы»; naтриот в значении «национал - патриот», отказник в значении «тот, кто отказывается от исполнения своих обязанностей, в частности от службы в армии; теневик в значении «представитель теневой экономики»; аграрий в значении «член Аграрной партии России», гарант в значении «президент РФ», фундаменталист в значении «непримиримый сторонник религиозных или политических догм, проявляющий агрессивность в отстаивании своих взглядов» и др.). Ср. также расширение семантической структуры слова автономия. До середины 80-х годов толковые словари русского языка фиксировали одно значение названной словесной единицы: «Право самостоятельно решать дела внутреннего законодательства и управления; самоуправление» $[8$, т. 1 , с. 23]. Современные лексикографические издания указывают еще одно значение: «Обособленность, самостоятельность, независимость» [9]. 


\section{ТРАДИЦИИ И ИННОВАЦИИ В СОВРЕМЕННОЙ НАУКЕ И ОБРАЗОВАНИИ: ТЕОРИЯ И ПЕРЕДОВАЯ ПРАКТИКА}

На один лексико-семантический вариант в современную эпоху увеличилась семантическая структура слова плюрализм: «плюрализм философское учение, отрицающее единство мира и утверждающее, что в основе мира лежит множество самостоятельных независимых начал и видов бытия» [8, т. 3, с. 147]; «плюрализм - 1) философское учение, согласно которому существует несколько (или множество) независимых духовных начал бытия; 2) многообразие и свобода взглядов, идей, форм деятельности» [10].

Как показывают исследования политической лексики и фразеологии, в советское время были известны термины «красно-зеленые» в значении «участники партизанского движения против белогвардейщины» и «белозеленые» в значении «кулацкие банды и остатки разгромленных белых армий». Указанные словесные знаки в настоящий период утратили свою актуальность, однако цветовая лексема «зеленый» активно функционирует в СМИ. Отметим, что семантическая структура слова «зеленый», представленная ранее одним ЛСВ «участник контрреволюционного партизанского движения периода гражданской войны», в настоящее время имеет два значения: «1) в период гражданской войны - свободолюбивый крестьянин, боровшийся против белого монархического движения и против власти красных комиссаров; 2) участник общественного движения, проводящий экологическую политику, направленную на охрану и оздоровление природной среды». Кроме того, в последнее время слово «зеленый/зеленые» является частотным в разговорной речи и средствах массовой коммуникации для обозначения долларов США.

Ср. словосочетание «красные директора», которое также расширило план содержания, представленный в настоящее время двумя ЛСВ: «1) уполномоченные ВКП (б) коммунисты, поставленные во главе предприятий на рубеже 20-х годов XX века; 2) в современной России - директора предприятий, назначенные на руководящие должности в советское время и оставшиеся на своих постах до настоящего времени, а также руководители, отличающиеся таким стилем руководства, как авторитаризм, некомпетентность в юридических и финансовых вопросах и др.».

Ср. также появление новых ЛСВ у следующих словесных знаков: «наместник - о представителе Президента на местах (с пом. разг. перен.)»; «правый - в общественно-политической жизни Советского Союза в период перестройки и (реже) в настоящее время: коммунистический и прокоммунистический, верный идеям марксизма, отвергающий 
демократические преобразования; выражающий такие взгляды»; «правительство - В России в наст. время: высший исполнительный орган власти некоторых субъектов Российской Федерации, член такого органа» [11].

Очевидно, что появление новых ЛСВ в семантической структуре политических единиц современного русского языка может быть обусловлено различными причинами: с одной стороны, стремлением к однословному обозначению реалий, имеющих в языке описательное выражение, с другой стороны - необходимостью в обозначении новых реалий, появление которых связано с изменениями в политическом устройстве общества и в сфере идеологических отношений. В первом случае появление новых ЛСВ общественно-политических словесных знаков обусловлено действием внутриязыковых факторов развития языка т.е. внутриязыковой антиномией, в частности, антиномией кода и текста, информационной и экспрессивной функциями языка; во втором случае - действием внешних причин, связанных с влиянием на развитие языка общества, его социально-политического устройства.

Появление семантических неологизмов может быть связано также со снятием «идеологических наслоений» в плане содержания словесных знаков (cp. исчезновение идеологизированного семантического компонента «сторонник буржуазных партий, течений в капиталистических государствах» в словах «радикал» и «пацифист»; ср. разрушение сем «реакционный, консервативный, враждебный передовым течениям» в словах «правый» и «демократ») или с «переориентацией номинаций» (ср. снятие семы «в дореволюционной России» в словах «буржуазия», «дворянство», «кадет», «волость», «градоначальник», «губерния» и др.). Самую большую группу переориентированной общественно-политической лексики составляет лексика, обозначающая наименование административных лиц, должностей и учреждений (ср., напр., мэр, спикер, префект, префектура, супрефект, президент, департамент, парламент, премьер-министр и др.).

Возникновение функцонально-семантических политических неологизмов связано с изменениями в содержании функциональностилистического компонента значения, несущего информацию о речевом употреблении слова и отражающего изменения в характере его функционирования: сужении или расширении сферы употребления слова, увеличении или уменьшении частотности его употребления в речи, 
отнесенности к разряду устаревшей или новой лексики (ср., напр., ставшие высокочастотными и широкоупотребительными словесные знаки «губернатор», «думец», «политолог», «плутократ», «партократ», «олигарх»; ср. малоупотребительные в настоящее время слова «фарцовщик», «перестройщик», «горбачевец», «сталинист», ушедшие в пассивный словарных запас) [12; 13$].$

В современном русском языке под воздействием заметно возросшей политизации общества пополнение политического словаря происходит также за счет появления значений, связанных со сферой политической и парламентской деятельности, у целого ряда слов. Так, например, в сферу политических контекстов втягиваются слова «ближневосточный» (связанный с политически и военным конфликтом на Ближнем Востоке); «вертикаль» (иерархическая последовательность должностных лиц, организаций); «команда» (ближайшее окружение политического лидера или должностного лица, работающее над реализацией его программы), «прогнозист» (тот, кто официально высказывает прогнозы по поводу ближайших политических событий), «бархатный» (ненасильственный, совершенный путем выборов - о политическом строе), «взрывоопасный» и др., изначально не имевшие отношения к политике.

Таким образом, расширение состава политической лексики и фразеологии за счет отмеченных выше новообразований, обусловленное, прежде всего, общественно-политическими процессами в российском государстве, относится к собственно количественным изменениям в системе русского языка и может рассматриваться как весьма активный, динамический процесс, представляющий огромный интерес не только для исследователей - лингвистов, но и для всех, кто интересуется вопросами языкового развития, языковой политики и языкового вкуса.

\section{Список литературы}

1. Костомаров В. Г. Языковой вкус эпохи. Из наблюдений над речевой практикой масс-медиа. - М., 1999. - 320 с.

2. Крысин Л.П. Лексическое заимствование и калькирование// Современный русский язык: Активные процессы на рубеже XX XXI веков. М.: Языки славянских культур, 2008. - 712 с.

3. Стернин И.А. Общественные процессы и развитие современного русского языка. Очерк изменений в русском языке конца XX века. - Воронеж, 2003. -209 c. 
4. Крысин Л.П. К определению терминов «заимствование» и «заимствованное слово» // Развитие лексики современного русского языка. - М., 1965. - C. 104-116.

5. Валгина Н.С. Активные процессы в современном русском языке. - М.: Логос, 2001. - 304 с.

6. Загоровская О.В. Русский язык на рубеже XX- XXI веков: исследования по социолингвистике и лингвокультурологии: монография. Воронеж: Научная книга, 2013. - 232 с.

7. Заварзина Г.А. Сложные слова в русском языке новейшего периода (на материале тематической сферы «Государственное управление») // Слово в пространстве языка. - Ульяновск, 2012. - С. 26-30.

8. Словарь русского языка: в 4-х тт. / под ред. А. П. Евгеньевой. - 2-е изд., испр. и доп. - М.: Русский язык, 1981-1984. - Т. 1-4.

9. Толковый словарь русского языка начала XXI века. Актуальная лексика/ под ред. Г.Н. Скляревской. - М.: Эксмо, 2008. - 1136 с.

10. Заварзина Г.А. Государственное управление: актуальная лексика русского языка начала XXI века. Словарь-справочник. - Воронеж: ВГПУ, 2012. $-236 \mathrm{c}$.

11. Заварзина Г.А. К вопросу о специфике дискурса нового государственного управления// Лингвориторическая парадигма: теоретические и прикладные аспекты. - Сочи, 2020. - №25(1). - С.164-167.

12. Заварзина Г.А. Лексика русского языка новейшего периода: структурно-семантическое исследование (на материале лексической подсистемы государственного управления): монография. - Воронеж: ИПЦ «Научная книга», 2017. - 163 с.

13. Zavarzina G.A. Lexical-semantic subsystem of government management and linguistic rules // Scientific research of the SCO countries: synergy and integration: materials of the International Conference. - P. 1 (February 26, 2019). Beijing, PRC. - 126-133 pp. 
УДК 821.161.1, 82-65, 82-155

\title{
ИЗ ИСТОРИИ ЭПИСТОЛЯРНЫХ ОБРАЩЕНИЙ М.В.ЛОМОНОСОВА В ВЫШЕСТОЯЩИЕ ИНСТАНЦИИ
}

\author{
Суровцева Екатерина Владимировна \\ к.ф.н., с.н.с.
}

Московский государственный университет им. М.В. Ломоносова

Аннотация: В русле наших исследований жанра «письма царю» ставится вопрос об изучении текстов, созданных в XVIII веке и адресованных н царским ближайшим сподвижникам. Рассмотрение материала следует начать с 17 писем М.В.Ломоносова 10 адресатам - Г.Н.Теплову, К.Р.Разумовскому, И.А.Черкасову, П.И.Шувалову, Р.И.Воронцову, Г.Г.Орлову, Ф.Г.Орлову, А.М.Голицыну, И.Г.Чернышёву, А.А.Вяземскому. Нами выделено 8 основных тем этих писем.

Ключевые слова: эпистолярная литература, XVIII век, «письмо властителю», «письмо царю», М.В.Ломоносов.

\section{FROM THE HISTORY OF EPISTOLARY APPEALS BY M.V.LOMONOSOV TO HIGHER AUTHORITIES}

\section{Surovtseva Ekaterina Vladimirovna}

Abstract: In context with our research of genre of «Letter to Tsar» the question of studying the texts created in the XVIII century and addressed companions of tsar, is asked. The review of the material should begin with 17 letters by M.V.Lomonosov to 10 addressees - G.N.Teplov, K.R.Razumovsky, I.A.Cherkasov, P.I.Shuvalov, R.I.Vorontsov, G.G.Orlov, F.G.Orlov, A.M.Golitsyn, I.G.Chernyshev, A.A.Vyazemsky. We have identified 8 main topics of these letters.

Key words: epistolary literature, XVIII century, «Letter to Ruler», «Letter to Tsar», M.V.Lomonosov.

Эпистолярный жанр является одним из важнейших источников для изучения истории литературы и взаимодействия литературы и власти. Тексты 
данного жанра находятся на грани между бытовым фактом и литературным явлением [1; 2; 3]. В данном аспекте прежде всего необходимо подробное исследование так называемого «письма властителю», до сих пор неисследованного, имеющего в нашей культуре два инварианта - «письмо царю» и «письмо вождю». Послания данного жанра, написанные авторамилитераторами и направленные во властные структуры, являются объектом проводимого нами исследования. Следует также отметить, что анализируемый жанр подразделяется на целый ряд подразновидностей, таких, как жалоба/просьба/оправдание, декларация, дифирамб/благодарность/творческий отчёт, инвектива, памфлет, донос (обоснование темы, обзор и рассмотрение материала, относящегося к XIX - XX векам, см. в [1; 2; 3]). Анализ этого материала, использовать который можно в преподавании биографий и творчества русских писателей и истории жанров, поможет нам уточнить и расширить наши представления о взаимоотношениях литературы и власти в нашей стране. Именно это определяет актуальность нашего исследования. Состав текстов, относящихся к «письму царю», постоянно пополняется, в том числе за счёт материала, относящегося к истории русской литературы XVIII века (отметим, что жанр дружеского письма этой эпохи уже получил подробное освещение [4], однако письма Ломоносова, как и письма А.П.Сумарокова, в этом аспекте также не анализировались); кроме того, встаёт вопрос об изучении текстов, адресованных не царям, а им сподвижникам и приближённым, что определяет научную новизну нашего исследования. Практическая ценность работы является возможность использования её результатов и общих выводов в преподавании русской литературы и цензуры.

В данной статье речь пойдёт о 17 письмах М.В.Ломоносова, направленных 10 адресатам (16 писем М.И.Воронцову и 32 письма И.И.Шувалову должны быть проанализированы отдельно; обратим внимание на то, что императорам Ломоносов не направил ни одного письма). Это послания, адресованные Г.Н.Теплову, К.Р.Разумовскому, И.А.Черкасову, П.И.Шувалову, Р.И.Воронцову, Г.Г.Орлову, Ф.Г.Орлову, А.М.Голицыну, И.Г.Чернышёву, А.А.Вяземскому. Тексты анализируются нами в хронологическом порядке.

20 апреля 1748 г. Ломоносову Канцелярией Академии Наук был послан ордер о переводе немецких стихов к проекту иллюминации, назначенной на 25 апреля 1748 г. по случаю годовщины коронации императрицы. Проект этой 
иллюминации с «изъяснением» и стихами на немецком языке был составлен Я.Я.Штелиным. В письме от 22 апреля 1748 г. Григорию Николаевичу Теплову (Сенатору, действительному тайному советнику, действительному члену Академии наук и художеств, почётному члену Императорской Академии наук и художеств (с 1747 г.), фактическому руководителю Академии с 1746 по 1762 г.) [5, т. 10, с. 438] Михайло Васильевич пишет, что порученного ему перевода он сделать не может из-за того, что в «немецких виршах нет ни складу, ни ладу» досадно переводить подобную чепуху к такому празднику. И отступить от предложенного ему текста он также не может, не зная плана иллюминации. Ломоносов указывает на абсурдность ситуации - один человек раскрывает рот, а другой поёт; точно также - один делает изображение иллюминаций, а другой - сочиняет надписи. Именно поэтому так мало иллюминаций, достойных удивления («кроме разноцветных огней»). Было бы лучше, если бы требовали одновременного выполнения и изображений, и надписей. Михайло Васильевич просит прислать ему план, имея который он мог бы быстро выполнить свою работу. Теплов ответил Ломоносову в тот же день, однако прислал не необходимы ему план, а «изъяснение» иллюминации, и добавил, что просит сочинить стихи на русском языке так, как поэту покажется лучше, и чтобы не обидеть Штелина, нужно, помимо сочинения своих стихов, перевести на русский уже предоставленный Михаилу Васильевичу текст, и пусть Канцелярия артиллерии оценит оба текста и сама выберет то, что сочтёт наилучшим. Кроме того, Теплов предостерегает Ломоносова от горячности в отношении Штелина, так как каждый волен писать, как хочет, а письмо Михайла Васильевича «таких экспрессий наполнено, которые «предосудительны чести» советника [6, т. VIII, с. 71 - 72] - таким образом, Ломоносову был сделан своего рода выговор за резкие выражения в адрес советника. Михайло Васильевич добросовестно выполнил данное ему в последнем письме Теплова поручение - он представил в Канцелярию Академии Наук и свою собственную стихотворную надпись, и перевод стихов Штелина [6, т. VIII] (тексты обоих надписей см. в [5, т. 8]). Следующее письмо (точнее, черновик письма) Теплову датируется 30 января 1761 г. (месяц и день установлены предположительно по тексту - Ломоносов пишет, что «вчерашнего числа Клейнфельд удавился» - известно, что самоубийство адъюнкта М.Клейнфельда произошло 29 января 1761 г.) [5, т. 10, с. 547 - 554]. Свои основные задачи Михайло Васильевич обозначает как «распространение 
наук в отечестве» (в другом месте письма он употребляет слово «утверждение») и «польза российского юношества». Именно в этом он видит «действительную пользу академии», для него именно эти задачи «всего в жизни дороже». С первых же шагов по академической службе Ломоносов столкнулся с кознями и противодействием тех, кого он в этом письме именует недоброхотами, неприятелями и опасными противоборниками российских наук и учёных. Судя по предшествующим высказываниям Михайла Васильевича, недоброхотами он считал начальствующих в Академии иностранцев и полагал, что если он сам займёт в Академии руководящий пост, с подобным положением вещей будет покончено. В 1757 г. он и получил такой пост - он был назначен членом Академической канцелярии. И далее полномочия Ломоносова расширяются - в следующем же году ему поручается наблюдение над всей научной частью Академии, а ещё через два года, в 1760 г., на него возлагается единоличное руководство Университетом и Гимназией. (Отметим, что о создании должности вице-президента Академии Наук и о назначении себя на эту должность Ломоносов хлопотал в письме М.И.Воронцову от 30 декабря 1759 г. [5, т. 10, с. 535 - 537], однако ходатайство не было удовлетворено). Однако к моменту написания анализируемого письма Михайло Васильевич успел «слёзными опытами» убедиться в том, что все действия недоброхотов продолжали оставаться такими же действенными. Судя по письму, Ломоносов пришёл к выводу, что у иностранцев были русские высокопоставленные «пособники» - Михайло Васильевич прямо говорит, что виной всем «академическим несчастиям» - «непостоянство» Теплова («Тот сегодни в чести и в милости, завтре в позоре и упадке. Тот, кто выслан с бесчестием, с честию назад призван») и «добросердечие» президента Академии К.Р.Разумовского. Кроме того, сам Ломоносов сделался жертвой наветов - на него несправедливо пожаловались два студента - Лобысевич и Девович (об их увольнении см. в документе под названием «Определение Канцелярии АН об увольнении студентов А.Лобысевича и С.Девовича», датированном 16 июня 1760 г. [5, т. 9, с. 568 - 569]), первый из них приходился сватом Теплову. Особенно подробно в письме сказано о Миллере - «Из многих примеров нет Миллерова чуднее». Миллер - автор «вздорной диссертации о российском народе», занимает должность профессора - и за тридцать лет пребывания на этой должности никогда лекций не читал и ничего достойного не написал, ведёт «тайную, непозволенную и подозрительную с иностранными переписку», в зависимости 
от очень переменчивых отношений с Тепловым то назначается на высокие посты, то их лишается (так, из ректоров Университета его перевели в адъюнкты и затем сразу в секретари конференции с прибавкой жалования), имеет право писать и печатать по-немецки о России всё, что ему вздумается. «Всеватель недоброхотных и занозливых мыслей в «Месячные сочинения» получает за то похвалы и награждения. Все сие происходит чьим старанием? - Вашего высокородия. И надеясь на вас, не хочет и не думает отстать от своих наглых глупостей и презирает указы, посылаемые из Канцелярии. Обратитесь на прошедшее время и вспомните, сколько раз вы мне на Шумахера и на Миллера жаловались». Таким образом, Ломоносов прямо обвиняет адресата в творящихся в Академии беспорядках. Однако не теряет надежды: «я пишу ныне к вам в последний раз, и только в той надежде, что иногда приметил в вас и добрые о пользе российских наук мнения. Ещё уповаю, что вы не будете больше ободрять недоброхотов российским учёным». Учёный призывает Теплова «ободрять» не только недоброхотов, но и «сын[ов] отечества, кои уже имеют знатные в науках и всему свету известные заслуги». Тем самым Теплов заслужит «в прежнем прощение» и «немалую похвалу».

Первое письмо Ломоносова президенту Академии Наук (в 1746 - 1765 гг.) Кириллу Григорьевичу Разумовскому написано между 12 июля и 3 сентября 1748 г. [5, т. 10, с. 458 - 459]. Из его первой фразы следует, что в этом послании содержится повторная просьба о присвоении академикам «рангов» (ранее Михайло Васильевич от имени «всех профессоров» уже обращался в канцелярию с «челобитной» от 12 июля 1748 г. [7, с. 129; 8, с. 111], которая до сих пор не разыскана). Вопрос о «рангах» академиков, то есть присвоении должности академика первого из четырнадцати предусмотренных петровской «Табелью о рангах» «классов», был очень важным для нашей страны. Нашим правительством был поставлен вопрос так, что социальное положение человека в обществе должно определяться заслуженным им служебным рангом, а не происхождением. Человек, достигший первого из восьми рангов, получал потомственное дворянство, вне зависимости от того, в каком сословии он родился. «Табель о рангах» была издана в 1722 г. - ещё до учреждения Академии, именно поэтому академические чины никак не могли быть в ней предусмотрены. Такое положение дел создавало немалое количество препятствий отдельным людям и сильно мешало Академии как организации и нашей науке вообще - учёные на академическую службу не шли. Отметим, что 
в Новом регламенте Академии, который был составлен Г.Н.Тепловым и утверждён императрицей в 1747 г., ранги в принципе не упоминались. Ломоносов пишет, что «...Ваше сиятельство чрез особливую е. и. в. к вам высочайшую милость имеет случай в рассуждении сего сделать два великие дела, то есть, исходатайствовав нам ранги, умножить в российском народе почтение и охоту к наукам, а себе тем приобрести вечную славу». Положение, при котором учители Морской академии, по своему уровню и образованию не дотягивающие даже до академических адъюнктов, имели тот же самый ранг, что и академики. Кроме того, Михайло Васильевич отмечает ненормальность положения, сложившегося в XVIII веке, когда учёные оказались обделены рангами, хотя иностранцы находились в более выгодном положении, нежели свои собственные граждане. «Все природные и чужестранные в службе е. в., кроме нас, почтены пристойными рангами». Обсуждение вопроса об академических рангах, вызванное, как можно предположить, обоими обращениями Ломоносова, состоялось 3 сентября 1748 г. при участии трёх глав Академии Наук - К.Г.Разумовского, И.-Д.Шумахера и Г.Н.Теплова. Однако, к сожалению, на основании неверного толкования «Табели» в Канцелярии пришли к выводу о ненужности обсуждения вопроса о рангах для академиков, вместо этого было предложено ходатайствовать перед Сенатом о присвоении рангов адъюнктам, студентам и «разных художеств художникам». Соответствующее доношение в Сенат было сразу же составлено, однако по адресу не отправлено. Следующее письмо Ломоносова Разумовскому датируется 22 - 23 февраля 1753 г. [5, т. 10, с. 476 - 477]. Подлинник этого текста нами до сих пор не найден, в связи с чем нам неизвестна середина текста. Мы можем анализировать только дошедшие до нас фрагменты послания. Из этих фрагментов явствует, что Михайло Васильевич хочет лично передать Разумовскому отчёты о результатах своей научной работы и попросить своего высокопоставленного адресата об оформлении исправного паспорта и о разрешении съездить в Москву (там в то время находился императорский двор) по делам устройства мозаичной фабрики (см. об этом: «Доношение в Канцелярию АН о предоставлении отпуска в Москву по делам фабрики б успехах присланного из канцелярии от строений ученика П.Дружинина» от 17 февраля 1753 г. [5, т. 9, с. 83 - 85]; «Доношение в контору Сената о выдаче паспорта для проезда в Москву» от 17 - 22 февраля 1753 г. [5, т. 9, с. 85 - 86]; «Обязательство вернуться к назначенному сроку в Академию 
Наук от 22 февраля 1753 г. [5, т. 9, с. 86]; «Рапорт в Канцелярию АН об отъезде в Москву» от 23 февраля 1753 г. [5, т. 9, с. 86 - 87]; «Рапорт в канцелярию АН о возвращении из Москвы» от 24 марта 1753 г. [5, т. 9, с. 87]). Паспорт и разрешение на поездку необходимо получить поскорее, так как зимняя дорога скоро испортится. Третье и последнее письмо Ломоносова Разумовскому датируется приблизительно 28 января - 5 февраля 1763 г. [5, т. 10, с. 562 - 563]. В нём Михайло Васильевич хочет доложить Кирилла Григорьевича о работе «академических департаментов», порученных ему «в особливое смотрение», и принять его «уведомления и мнения». Очевидно, речь идёт о таких документах, как «Отчёт о состоянии Университета и Гимназии» от 28 января - 5 февраля 1763 г. [5, т. 9, с. 593 - 595], «Краткое показание о происхождениях академического Географического департамента» от 28 января - 5 февраля 1763 г. [5, т. 9, с. 258 - 269] и «Отчёт о состоянии Физической камеры, Обсерватории и Ботанического сада» от 28 января - 5 февраля 1763 г. [5, т. 10, с. 258 - 260]. Далее в письме следуют просьбы. Во-первых, надо изменить в сторону увеличения жалование на содержание гимназистов - оно составляет 36 рублей в год, а требуется 48 рублей (то есть речь идёт о надбавке в 12 рублей). Вовторых, необходимо сохранить расположение Географического департамента и защитить его от Г.-Ф.Миллера - это дело может пострадать из-за личной неприязни Миллера к Ломоносову, и причина неприязни - зависть (Миллер, по Ломоносову, по этой причине строит Михайлу Васильевичу препоны). Втретьих, следует поручить профессору И.-А.Брауну надзор за физическими инструментами, заменив им Епиниуса, не выполняющего своих обязанностей. В-четвёртых, необходимо обеспечить свободный доступ профессору Н.И.Попову в Астрономическую обсерваторию - этот учёный должен читать в обсерватории лекции, адъюнкту А.Д.Красильникову, геодезистам и студентам астрономии и географии. Насколько нам известно, на это послание глава Академии не отреагировал. Установлено, однако, что вопрос об увеличении жалования гимназистам так и не был решён до самого конца жизни Ломоносова. Руководство Географическим департаментом было сохранено за ним, несмотря ордер президента (см. «Краткое показание о происхождениях Академического Географического департамента» от 28 января - 5 февраля 1753 г. [5, т. 9, с. 258 - 269] и «Представление в Канцелярию АН с протестом против передачи Географического департамента в ведение Г.-Ф.Миллера» от 5 февраля 1763 г. [5, т. 9, с.269 - 274], а также примечания к названным текстам). Что 
касается Физической камеры, Обсерватории и Ботанического сада, то Ломоносов был вынужден повторно обращаться с той же просьбой относительно Брауна, Попова, Красильникова и студентов-географов - уже в жанре делового документа от 4 марта - более чем год спустя (см. «Представление в Канцелярию АН о неисправном состоянии Академической обсерватории, физической палаты и Ботанического сада» от 4 марта 1764 г. [5, т. 10 , с. 264 - 266]), но просьба так и не была удовлетворена.

Деловые отношения Ломоносова с кабинет-секретарём Иваном Антоновичем Черкасовым завязались в 1744 г., когда Михайло Василевич был вызван в Кабинет для пробы «солей российских». По поручению Кабинета и Берг-коллегии им был выполнен ряд анализов [5, т. 5, с. 253 - 262, 291 - 294]. Ломоносову был поручен также анализ меди, найденной близ Камчатки иркутским служилым человеком Дмитрием Наквасиным и доставленной в Бергколлегию. Один фунт этой меди был затребован Кабинетом на пробу сопоставима ли эта медь по качеству с японской. После проведённых анализов Михайло Васильевич направил Черкасову письмо от 27 июля 1749 г. [5, т. 10, с. 467] с изложением результатов - он сделал анализ полфунта чистой и полфунта нечистой меди и получил количество содержания чистой меди в нечистой, оценил качество камчатской чистой меди (она превосходит шведскую медь и равноценна японской), выяснил, что золота и серебра в меди не содержится. В общем и целом Ломоносов высоко оценил качество нашей меди. Получив письмо Михайло Васильевича, Черкасов распорядился отправить на Камчатку искусного горного офицера из Берг-коллегии для полного географического описания этого металла, для полной оценки его расположения и выяснения способов добычи, дабы в дальнейшем развить его добычу на разные «потребы». Это мероприятие было осуществлено через пять лет, в 1754 г. [5, т. 10, с. 806].

10 мая 1753 г. Ломоносовым написано письмо Петру Ивановичу Шувалову [5, т. 10, с. 477 - 478], бывшему в годы царствования Елизаветы Петровны одним из самых влиятельный государственных деятелей и автором целого ряда экономических реформ. В своём послании Михайло Васильевич поздравляет адресата с «новым оказанием высочайшей милости», заключавшимся в пожаловании Шувалову 30000 рублей, как сообщили «Санкт-Петербургские ведомости» (№ 35 за 1753 г.), за верную службу императрице и государству в изыскании способа увеличения кабацких и соляных доходов, то есть за установление по всей империи единых цен на вино 
и на соль. Ломоносов сообщает, что «показал» супруге Петра Ивановича Мавре Егоровне «малый опыт» нового для России «мозаичного художества» (малый мозаичный образок, который Ломоносов приложил к письму в качестве подарка) - видимо, под упомянутыми в письме «многими благодеяниями» Шувалова имеется в виду помощь адресата в деле устройства мозаичной фабрики - это дело обсуждалось в Сенате в декабре 1752 г., голос Петра Ивановича, вероятно, оказался решающим.

28 декабря 1761 г. Ломоносовым было написано короткое письмо Роману Илларионовичу Воронцову [9, с. 488; 5, т. 10, с. 558]. Это сердечное поздравление с «высочайшею монаршескою щедротою» - с указом императора Петра III от 28 декабря 1761 г. о возведении Р.И.Воронцова в «полные генералы с настоящим по тому чину жалованием» и назначении его членом Конференции при императорском дворце. Второе письмо Ломоносова Р.И. Воронцову написано 5 февраля 1763 г. [9, с. 489 - 490; 5, т. 10, с. 565 - 566]. «Освободясь» от долгой болезни, Ломоносов спешит поздравить адресата с новым годом и просит исхлопотать годовую сумму на строительство мозаичного дела, берущего своё начало от брата Романа Илларионовича - Михаила Илларионовича (см. также письмо Ломоносова Ф.К.Соколову от 24 июня 1762 г. [5, т. 10, с. 558 - 559], в котором учёный «поверяет» адресата получить деньги на мозаику). После свержения и смерти Петра III Р.И.Воронцов временно попал в опалу и был не у дел, однако Ломоносов надеялся, что Роман Илларионович сможет помочь ему через Михаила Илларионовича, который, будучи президентом Вотчинной коллегии в Москве, располагал обширными связями в московских служебных кругах. В конце письма Михайло Васильевич сообщает о завершении издательской работы над «горной книжицей» с «новыми прибавлениями», экземпляр которой обещает преподнести адресату. Речь идёт о сочинении «Первые основания металлургии или рудных дел»с двумя прибавлениями - «О вольном движении воздуха, в рудниках примеченном» и «О слоях земных». Книга была представлена для публикации в Канцелярию Академии Наук 5 февраля 1761 г., однако вышла в свет более чем два с половиной года спустя - в октябре 1763 г. [5, т. 5, с. 690]. О поступлении её в продажу было сделано специальное объявление в «Санкт-Петербургских ведомостях» (№ 89 от 7 ноября 1763 г.).

Первое письмо Ломоносова Григорию Григорьевичу Орлову написано 25 июля 1762 г. [5, т. 10, с. 560 - 561] после того, как в тот же день он, как следует 
из первых же слов послания, получил от Орлова какое-то приятное известие слово «присылание» наводит на мысль, что это было устное сообщение. Ломоносов выражает уверенность, что все «недоброхоты российские» будут посрамлены. Последние слова письма («...когда совершение вашего благодеяния истинно отеческого воспоследует, ибо оным все истинные сыны отечества от уныния восставлены или, лучше сказать, воскрешены будут...»), видимо, говорят о том, что речь идёт о каком-то обещании Орлова. После дворцового переворота 1762 г. М.И.Воронцов и И.И.Шувалов, покровительствовавшие Ломоносову, утратили своё былое влияние, Г.Г.Орлов же вошёл в силу, поэтому Михайло Васильевич и был «обрадован» его обещанием. Комментаторы письма в академическом собрании сочинений Ломоносова высказывают предположение, что, сопоставляя письмо Ломоносова М.И.Воронцову от 24 июля 1762 г. и анализируемое письмо Орлову, можно придти к выводу, что обещание Олова, данное, может быть, под влиянием Воронцова, могло касаться награждения Ломоносова повышением ранга и дела об утверждении «привилегии» для Академического университета. Говорил ли Орлов с императрицей по этим вопросам, неизвестно, однако мы знаем, что в результате оба вопроса остались нерешёнными. Отметим, что в письме присутствует изменённая автоцитата: «Ныне время златой здешним наукам век поставить...» (это строчка из оды Ломоносов на восшествие на престол Екатерины II [5, т. 8]). Второе письмо Ломоносова Орлову датируется интервалом времени 10 октября 1764 г. - март 1765 г. [5, т. 10, с. 589 - 590]. Из текста письма, в том числе из его подписи, явствует, что оно было написано от имени всех академиков, которые «по долгом рассуждении» одобрят составленные Ломоносовым же новый стат, регламент и привилегии Академии Наук. В послании говорится, что цель этих документов - «польза наук в России», так как по этому стату, регламенту и привилегии Академия в скором времени достигнет цветущего состояния к пользе государства и к славе императрицы. Разумовский отъезжает в чужие края - поэтому во избежание помех письмо с документами высылает Орлову (Разумовский уехал за границу в апреле 1765 г., уже после смерти Ломоносова). До рассмотрения упомянутых проектов академиками дело не дошло, на этом основании можно сделать вывод, что анализируемое письмо адресату отправлено не было.

Письмо Фёдору Григорьевичу Орлову было написано Ломоносовым 26 июля 1762 [5, т. 10, с. 561 - 562]. Для подтверждения «законного прошения» 
Ломоносов прилагает к этому своему письму документы и просит передать их Г.Г.Орлову - комментаторы письма полагают, что Ф.Г.Орлов исполнял роль посредника между Г.Г.Орловым и Ломоносовым, посетив Михайло Васильевича накануне и передав ему от Г.Г.Орлова обещание поддержки и помощи. К сожалению, приложенные к письму документы до нас не дошли. Тема письма - просьба о чине. Ломоносов не в первый раз в этом тексте ссылается на то, что за границей профессоров жалуют высокими чинами (см. также [6, т. VIII, с. 251 - 252 втор. паг.]). И далее следует неточная цитата из псалма 85 (стих 17): «...сотвори со мною знамение во благо, да видят ненавидящие мя и постыдятся, яко ты, господи, помоги ми и утеши мя еси...». В приписке к письму говорится, что «в чужих краях» чинами награждают профессоров, а не книгопродавцов, типографщиков и прочих ремесленников. В качестве такого награждённого типографщика Ломоносов называет Тауберта, 19 июля 1762 г. получившего чин статского советника. Михайло Васильевич намеренно искажает его фамилию, именуя его Таубергауптом - в буквальном переводе с немецкого языка это слово означает «голубиная голова». Отметим, что о Тауберте речь идёт и в письме Ломоносова М.И.Воронцову от 24 июня 1762 г. [5, т. 10, с. 559 - 560]: «... ныне всего несноснее я обижен, что г. Тауберт в одной со мною команде, моложее меня, коллежским советником восемь лет, пожалован статским советником без всякой передо мною большей заслуги ...» [5, т. 10, с. 559].

Письмо Ломоносова вице-канцлеру князю Алексею Михайловичу Голицыну написано 24 января 1754 г. [5, т. 10, с. 581]. Михайло Васильевич пишет, что императрица через И.И.Бецкого передала ему поручение выбрать из нашей истории «знатные приключения для написания картин», однако Ломоносов обнаружил сильный недостаток изображений старинной одежды. Подобные сведения в наиболее полом виде содержатся в Архиве Коллегии иностранных дел, подчинённом Голицыну. «Особливо» здесь должны быть описания церемоний царя Михаила Фёдоровича. К письму Голицыну приложена записка с заглавием «Идеи для живописных картин из российской истории» [5, т. 6, с. 365 - 373]. Михайло Васильевич просит адресата «подать ... великое вспомощестсвование» - видимо, имеется в виду, что Ломоносов просит переслать ему все необходимые для работы архивные материалы. Была ли удовлетворена эта просьба - неизвестно.

22 октября 1754 г. Ломоносовым написано письмо Ивану Григорьевичу Чернышёву [5, т. 10, с. 590 - 591] как члену и фактическому главе 
Адмиралтейств-коллегии (формально её президентом числился сын Екатерины II, будущий император Павел I, по малолетству не могущий исполнять свои обязанности). Это послание посвящено Северной морской экспедиции, которая снаряжалась Адмиралтейств-коллегией по инициативе Ломоносова и при его активном участии. В самом начале письма Михайло Васильевич пишет о штурманах, назначенных на экспедиционные суда и присланных Коллегией в Академию Наук для учебной подготовки, для чего необходимо как можно скорее получить «Гандлеевы квадраты» (см. [5, т. 6, с. 611 - 612]; а также документы «Записка в Канцелярию АН об избрании лиц для обучения присланных из Адмиралтейств-коллегии штурманов» от $24-28$ сентября 1764 г. [5, т. 9, с. 602], «Записка в Канцелярию АН об обучении присланных из Адмиралтейств-коллегии штурманов» от 3 декабря 1764 г. [5, т. 9, с. 606], «Записка в Канцелярию АН об обучении Н.И.Поповым и А.Д.Красильниковым присланных из Адмиралтейств-коллегии штурманов» от 3 декабря 1764 г. [5, т. 9, 606], «Ордер Н.И.Попову о подготовке к обучению совместно А.Д.Красильниковым присланных из Адмиралтейств-коллегии штурманов» от 16 декабря 1764 г. [5, т. 9, с. 606 - 609], «Определение Канцелярии АН о порядке обучения присланных из Адмиралтейств-коллегии штурманов» от 31 декабря 1764 г. [5, т. 9, с. 609 - 610]). Далее по пунктам перечисляются три просьбы, или, как их называет сам Ломоносов, «статьи», первая и третья их которых были исполнены незамедлительно. Первая просьба состояла в том, вернувшиеся со Шпицбергена могли бы «проинструктировать» вновь отъезжающих. 26 октября 1764 г. Коллегия постановила велеть вернувшемуся с северных земель лейтенанту Немтинову немедленно прислать в Коллегию журнал путешествия [10, с. 486]. Третья просьба касается сведений купца Снигирёва «с товарищем» о «незахождении» солнца на Умнаке, в связи с чем было бы правомерно найти хотя бы одного человека из промышленников, бывших на Умнаке, «для лучшего сведения» - эти промышленники могут найтись в Иркутске, Якутске, Охотске. Того же 26 октября 1754 г. Коллеги приняла решение отправить к сибирскому губернатору Д.И.Чичерину курьера с поручением прислать в столицу кого-либо из промышленников, бывавших на Умнаке. Во второй «статье» говорится о том, что Ф.Х.Плениснер, участник Второй камчатской экспедиции, состоявший с 1760 г. командиром Охотского края, занимавшийся изучением береговых очертаний северо-западной Сибири (у Ломоносова и у некоторых иных авторов написано Пленистер), близ 
Чукотского носа открыл новые острова, назвал их Медвежьими и хотел послать туда вторую экспедицию, что и надо сделать. Однако тут Михайло Васильевич не вполне точен - сержант С.Андреев, в 1763 г. командированный Плениснером в устье Колымы для изучения островов, был одним из первых, кто обследовал их (некоторые из этих островов были открыты ранее) и нанёс их на карту; тогда же командир Охотского края назвал их Медвежьими - именно поэтому Ломоносов называет острова новыми и честь их открытия приписывает Плениснеру. Карта, составленная Андреевым, попала в руки Михайла Васильевича, который предоставил её в Адмиралтейств-коллегию 18 февраля 1765 г. Так что на этот раз помощь Коллегии Ломоносову не понадобилась. Ещё одно письмо Ломоносова Чернышёву от 26 октября 1754 г. [5, т. 10 , с. 592] имеет прямую связь с предыдущим письмом. В нём речь идёт об изготовлении Гандлеевых труб для Северной морской экспедиции (см. также [5, т. 6, с. 620 - 621; 10, с. 346 и 487]) и подзорных труб, а также о нездоровье автора данного письма, которое мешает его «выезду» - видимо, под «выездом» имеется в виду какая-то деловая поездка, связанная с подготовкой к экспедиции. Судя по записям в журнале Канцелярии Академии Наук, Михайло Васильевич не выезжал из дома по болезни с 20 октября по 13 декабря 1764 г. Согласно тем же записям, навигация по Неве в 1764 г. закрылась 23 ноября.

3 февраля 1765 г. Ломоносов направил письмо князю Александру Андреевичу Вяземскому [5, т. 10, с. 583 - 594], бывшему в то время генералпрокурором. Сразу после реформы Сената 1763 г. была расширена и Сенатская типография. 10 августа 1764 г. (то есть в следующем же году после реформы) был утверждён её штат и отпущены средства на её содержание и переоборудование. Надзор за типографией был поручен генерал-губернатору, то есть в данном случае Вяземскому. По новому положению Сенатской типографии предписывалось печатать не только официальные акты, но и «частные сочинения». Учитывая весьма незначительное количество петербургских типографий и при их «узко ведомственном» характер (только Академическая типография была исключением - она не была ведомственной) преобразование Сенатской типографии оценивалось Ломоносовым, судя по всему, как крупное событие нашей общественной жизни, что и объясняет его активное участие, которое он принял в этом деле по просьбе князя. В письме Вяземскому Михайло Васильевич пишет, что купец Клаузинг обещался взять на себя всю переписку с Англией по поводу типографского дела и нуждается в указаниях - «людей ли нужнейших выписать или по данному примеру 146 
приказать там сделать требуемые российских литер алфавиты?». Второй вариант он считает более удобным. Кроме того, Ломоносов предлагает послать в Англию несколько наших людей, которые будут там проходить обучение, пока здесь будут служить «выписанные алфавиты». На эти прожекты Михайло Васильевич просит приказания. Однако Вяземский Ломоносова не поддержал и в тот же день, 3 февраля 1765 г., в ответном письме написал, что лучше и нужнее выписать из Англии иностранных специалистов и поэтому нужно уговорить Клаузинга взять на себя соответствующие хлопоты и сообщить ему, Вяземскому, о требуемых на это расходах [6, т. VIII, с. 309]. В ответ на письмо Вяземского Ломоносов 4 февраля 1765 г., то есть на следующий же день, отправил князю ещё одно письмо [5, т. 10, с. 594 - 595]. Михайло Васильевич предлагает пригласить в нашу новую типографию только четырёх иностранцев - словолитного мастера, который был и пунсонщиком, с подмастерьем и мастера печатного дела с подмастерьем, причём оба мастера обязаны будут учредить в Петербурге «исправную российскую типографию», в которой будут трудиться «здешние российские наборщики», и обучить каждый до пяти наших мастеров. «По сему предписанию» желающие могут присылать свои «кондиции» - сроки работы в России, размер жалования, квартира и прочее. Если Вяземскому все предложенные предписания угодны, то можно сразу же связаться с Англией и на первых же кораблях привезти к нам нужных мастеров. Вяземский согласился с ломоносовскими предложениями и просил его именно в таком духе и вести переговоры с англичанами [6, т. VIII, с. 311]. Документальных следов дальнейшего участия Михайла Васильевича в деле учреждения типографии пока не обнаружено.

Итак, можно кратко перечислить основные темы писем Ломоносова властям: жалобы на «недоброхотов» (К.Г. Разумовскому); научная работа в области физики, химии, истории, лингвистики (И.А. Черкасову, А.М. Голицыну, И.Г. Чернышёву); мозаичное дело (П.И. Шувалову); устройство Академии наук, её проблемы и нужды (Г.Н. Теплову, Г.Г. Орлову); поздравление с получением чина (Р.И. Воронцову); Северная морская экспедиция (1764г.) (И.Г. Чернышёву); налаживание и усовершенствование российской типографской работы (А.А. Вяземскому); получение чинов и рангов ради развития отечественной науки (Г.Г. Орлову, Ф.Г. Орлову).

Говоря о перспективах заявленного нами исследования, следует отметить необходимость не только отдельного изучения эпистолярных обращений М.В.Ломоносова М.И.Воронцову и И.И.Шувалову (следует 
обратить внимание на то, что и в том, и в другом случае мы имеем дело не с письмами «в один конец», а с перепиской и с личными встречами), но и сопоставительного изучения писем А.П. Сумарокова и М.В. Ломоносова И.И. Шувалову, а также истории взаимоотношений двух литераторов XVIII века в свете этих посланий.

\section{Список литературы}

1. Суровцева Е. В. Жанр «письма царю» в XIX - начале XX века. - М.: АИРО-ХХІ, 2011. - $164 \mathrm{c}$.

2. Суровцева Е. В. Жанр «письма вождю» в тоталитарную эпоху (1920-е - 1950-6 годы). - М.: АИРО-ХХІ, 2008. - 168 с.

3. Суровцева Е. В. Жанр «письма вождю» в советскую эпоху (1950-е 1980-е гг.). - М.: АИРО-ХХІ, 2010. - 128 с.

4. Лазарчук Р. М. Дружеское письмо второй половины XVIII века как явление литературы. Автореферат диссертации на соискание учёной степени кандидата филологических наук. - Л.: Ленинградский ордена трудового красного знамени государственный педагогический институт имени А.И.Герцена, 1972. - 19 с.

5. Ломоносов М.В. Полное собрание сочинений. В 10 томах (с 1 дополнительным томом) / Глав. ред. С. И. Вавилов. М.-Л.: Издательство АН CCCP, $1950-1983$.

6. Ломоносов М. В. Сочинения. - В 8 т. - СПб.; М.; Л.: Издательство Академии Наук, 1891 - 1948.

7. Билярский П. С. Материалы для биографии Ломоносова. - СПб.: Типография Императорской Академии наук, 1865. - 820 с.

8. Моздалевский Л. Б. Рукописи Ломоносова в Академии Наук СССР: Научное описание / Сост. Л. Б. Модзалевский; отв. ред. Г. А. Князев; автор предисл. Б. Н. Меншуткин. - Труды Архива Академии Наук СССР. Вып. 3. Л.-М.: Изд-во АН СССР, 1937. - 404 с.

9. Архив Князя Воронцова / Под редакцией П. А. Бартенева. - Книга четвёртая. Бумаги графа Михаила Илларионовича Воронцова. - М.: Типография Ф. Иогансон на Новой Басманной, д. Соколовой, 1872. - 558 с.

10. Перевалов В. А. Ломоносов и Арктика. - М.-Л.: Издательство Главсевморпути, 1949. - 501 с.

(C) Е.В.Суровцева, 2021 
ГЛАВА ІІІ.

НЕКОТОРЫЕ ВОПРОСЫ ОБЕСПЕЧЕНИЯ БЕЗОПАСНОСТИ

\author{
ПОСТАВЛЕНИЕ В ОПАСНОСТЬ ЗАРАЖЕНИЯ \\ ЛИБО ЗАРАЖЕНИЕ ВИЧ-ИНФЕКЦИЕЙ (СТ. 122 УК РФ): \\ ОСНОВНЫЕ ПРИЧИНЫ И УСЛОВИЯ; \\ ЛИЧНОСТЬ ВИЧ-ИНФИЦИРОВАННОГО ПРЕСТУПНИКА
}

Бурдинская Анна Николаевна

к.ю.н., старший преподаватель

ФГАОУ ВО «Дальневосточный федеральный университет»

\begin{abstract}
Аннотация: В данной статье автор рассматривает причинный комплекс преступного поставления в опасность заражения либо заражения ВИЧинфекцией. Проведённое исследование детерминант ст. 122 УК РФ выявило, что существуют основные группы причин и условий таких преступлений, которые характеризуются своей неоднозначностью, своеобразностью, хотя они во многом схожи с общими причинами совершения преступлений против жизни и здоровья человека. В работе подробно исследованы детерминанты преступного поставления в опасность заражения или заражения ВИЧинфекцией в ракурсе выделенных автором двух групп: характеризующих определенные социальные группы, коллективы; характеризующих индивидуальное преступное поведение виновного в заражении ВИЧинфекцией. Особое внимание в исследовании уделено исследованию личности ВИЧ-инфицированного преступника, которая имеет свой самостоятельный тип.

Ключевые слова: ВИЧ-инфекция, причины и условия, преступность, детерминанты, причинный комплекс, поставление в опасность заражения ВИЧинфекцией, заражение ВИЧ-инфекцией, ст. 122 УК РФ, личность ВИЧинфицированного преступника, crime, infection, HIV infection, determinants.
\end{abstract}




\title{
ТРАДИЦИИ И ИННОВАЦИИ В СОВРЕМЕННОЙ НАУКЕ И ОБРАЗОВАНИИ: ТЕОРИЯ И ПЕРЕДОВАЯ ПРАКТИКА
}

\section{THE THREAT OF INFECTION OR INFECTION WITH HIV (ARTICLE 122 OF THE CRIMINAL CODE OF THE RUSSIAN FEDERATION): THE MAIN CAUSES AND CONDITIONS; THE IDENTITY OF THE HIV-INFECTED CRIMINAL}

\begin{abstract}
In this article, the author considers the causal complex of criminal putting at risk of infection or infection with HIV infection. The study of the determinants of Article 122 of the Criminal Code of the Russian Federation revealed that there are main groups of causes and conditions of such crimes, which are characterized by their ambiguity, originality, although they are largely similar to the general reasons for committing crimes against human life and health. The paper examines in detail the determinants of criminal exposure to the risk of infection or infection with HIV infection from the perspective of two groups identified by the author: those that characterize certain social groups, collectives; those that characterize the individual criminal behavior of the perpetrator of HIV infection. Special attention is paid to the study of the personality of an HIV-infected criminal, which has its own independent type.

Key words: HIV infection, causes and conditions, crime, determinants, causal complex, putting at risk of HIV infection, HIV infection, Article 122 of the Criminal Code of the Russian Federation, the identity of an HIV-infected criminal, crime, infection, HIV infection, determinants.
\end{abstract}

Следует согласиться с мнением П.С. Дагеля, который более тридцати лет назад утверждал, что эффективность предупреждения антиобщественных явлений прямо зависит от результатов теоретических исследований по выявлению причин и условий, порождающих преступные действия [1, с. 28]. Данное высказывание не потеряло своей актуальности и в настоящее время.

По утверждению экспертов, преступность обусловлена различными процессами, явлениями и состояниями, она многогранна и порождена множеством детерминирующих её факторов. Связь причин и условий в криминологии принято именовать детерминацией [2]. Отмечается, что причинность как ядро детерминации в общественном плане означает такую связь, в которой одно явление (процесс) при определенных условиях порождает, воспроизводит, продуцирует другое. Наряду с причинностью в систему детерминации входят иные связи, например, функциональные, 
корреляционные, связь состояний. Из всех категорий взаимосвязи (детерминации) для криминологии наибольшее значение имеют категории причин и условий, которые не менее латентны, чем сама преступность [3].

Описывая определённые причины преступности, криминологи выделяют факторы-причины преступности и факторы-условия, способствующие им. При этом причины и условия принято интерпретировать как определённые явления.

Помимо причин в криминологии существует понятие условий, способствующих совершению преступлений. К ним относятся как природные, так и социальные или технические факторы. Сами по себе эти условия не порождают преступлений, но помогают их реализации, осуществлению [4, с. 177-178]. Условие - это явление, способствующее действию причины. При отсутствии условия причина может быть блокирована.

Наряду с названными терминами криминологи часто используют в научном обороте такие понятия, как: «криминогенный / антикриминогенный фактор»; «обстоятельство, способствующее (препятствующее) преступности или совершению преступлений»; «обстоятельства» (не различая их: Б.С. Утевский, Н.А. Стручков и др.) [5, с. 213]; «детерминанты» (Н.Ф. Кузнецова, В.Н. Кудрявцев и др.) [6, с. 48]. Как верно отмечает Ю.М. Антонян, «эти понятия менее определены, поскольку в них не отражена их криминологическая значимость, т.е. остаётся неизвестным, относятся ли они к числу условий или к числу причин» [7, с. 66]. Вместе с тем, не вызывает сомнения мысль о том, что указанные понятия важны как для теории, так и для практики при разработке профилактических мер.

По нашему мнению, причины и условия преступности объединяются общим понятием детерминации преступности, т.е. объективной зависимости её причинной обусловленности от других явлений природы и общества [8, с. 7].

В криминологии выделяют два термина, позволяющие судить, насколько глубоко изучено то или иное явление. Первый - это описание явления (феномена) - «феноменологический уровень». Второй - выяснение причин того или иного явления (нефеноменологический уровень). Последнее направление представляет для данного исследования первоочередное значение, т.к. оно способствует не только выработке стратегии по противодействию распространению ВИЧ-инфекции в целом, но и позволяет бороться с преступным распространением ВИЧ в частности, а также влияет на увеличение рождаемости в России [9]. 
В криминологии всегда возникает проблема соотношения причин и условий преступности, причин преступности и причин индивидуального поведения. Так, причины преступности включают в себя наиболее общие, типичные, часто встречающиеся факторы, порождающие все факты преступного поведения. Однако действует и обратная тенденция: то, что вызывает преступность, в той или иной мере действует и среди обстоятельств, детерминирующих конкретное преступление. Как верно отмечает Ю.М. Антонян, «если в числе причин преступности большинство криминологов видит материально-экономическое неблагополучие людей, то, конечно, это же негативное явление можно обнаружить и у отдельного человека, решившегося на преступный шаг» [10, с. 66].

Анализ работ криминологов показывает, что существует четыре подхода при определении детерминант преступности.

Первый подход под причиной понимает необходимые и достаточные условия данного следствия, совокупность обстоятельств, при которых оно имело место («кондиционалистский»/условный подход). При этом вместо понятий «причины» и «условия» используются термины «обстоятельства» или «факторы», которые влияют на преступность. В криминологии выделяется несколько сотен факторов, порождающих преступность. В процессе развития криминологической мысли рассматриваемый подход развился в двух вариантах: однофакторном и многофакторном. Для этого подхода характерно накопление информации об обстоятельствах, порождающих преступность. Фактически кондиционалистский подход позволял описывать детерминацию как процесс в целом, не выделяя причины преступного поведения.

Второй подход - «традиционный», определяющий причины преступности как внешнее силовое воздействие (физическое либо психологическое) в различных его вариантах: человека должно что-то толкнуть на совершение преступления. Приверженцы данного подхода исследуют причины конкретного преступления, отдельных видов преступности, преступности в целом через анализ социальных явлений $[11$, с. 30]. Следует отметить, что традиционный подход редко применяется в криминологии, поскольку его авторы не могут объяснить возникновение внешнего силового воздействия. Именно по этой причине чаще всего криминологи прибегают к использованию традиционного и многофакторного подходов при интерпретации причин преступности [12, c. 293-294]. 
Третий подход - «традиционно-диалектический». При данном подходе воздействие условий на причины и причин на поведение является однонаправленным: в сознании человека условия переосмысляются и формируют причины, которые определяют совершение конкретного проступка. Этот подход наблюдается в трудах многих криминологов. Основными терминами рассматриваемого подхода являются понятия непосредственной или ближайшей причины преступления. Достоинствами традиционнодиалектического подхода следует признание как объективных, так и субъективных факторов. Вместе с тем, указанный подход носит фрагментарный характер и не учитывает всю совокупность причинного комплекса, порождающего преступность как социальное явление [13].

Четвёртый подход - «интеракционистский». Под причинами преступности и преступного поведения понимается взаимодействие среды (общества) и человека (личности). Выделяют внутренние и внешние причины, которые взаимообусловлены и находятся в неразрывной связи между собой. Данное взаимодействие приводит к изменению всей системы: общество криминализируется, человек приобретает преступный опыт, его личность приобретает качества, типичные для личности преступника. Иными словами, преступное поведение субъекта преступления обусловлено не только объективными условиями, прошедшими через сознание человека, но и новыми условиями, возникшими в ситуации криминального поведения. Сторонниками данного подхода выступили В.Н. Кудрявцев, Л.А. Волошин, А.И. Долгова [14].

В криминологии нет единства мнений по поводу того, какой из описанных подходов наиболее полно характеризует причины и условия преступности. Встречаются мнения, что не следует вообще выделять какиелибо детерминанты преступности. Так, по мнению Я.И. Гилинского, «в последнее время учёные всё чаще отказываются от самого термина «причина» и причинного объяснения своего объекта, предпочитают устанавливать корреляционные зависимости и выявлять факторы, воздействующие на объект исследования. Это связано с рядом обстоятельств. Мир очень сложен, взаимосвязи между системами и их элементами чрезвычайно сложны и многообразны. Очень трудно выделить причинно-следственную связь из всей совокупности связей даже в физических и биологических системах, не говоря уже о социальных, тем более когда сам объект не имеет естественных оснований в реальности, а суть социальная конструкция. Не удивительно, что 
большинство зарубежных криминологов отказываются от бесконечного поиска «причин» преступности и их умножения, обосновывая тезис «корреляции против преступности»»» [15].

В связи с вышесказанным необходимо подчеркнуть, что преступность всегда явление социальное, которое является результатом её взаимодействия с обществом и требует использования системного подхода при выявлении детерминант преступности. Разумеется, причины и условия нельзя противопоставлять друг другу. Конкретные факторы, являющиеся условиями совершения преступлений одного вида, могут быть причинами другого вида. Разработка основных направлений предупредительной деятельности и конкретных мер предупреждения преступности лиц, больных ВИЧ-инфекцией, должна основываться на всестороннем анализе комплекса взаимосвязанных причин и условий.

Разделение причин и условий на самостоятельные группы по определенному признаку носит условный характер и не означает полной обособленности одной группы от другой. Как преступность представляет собой целостное явление, в котором группы преступлений взаимодействуют друг с другом, так и причины и условия преступности, порождающие определённые виды (группы) преступлений, не изолированы.

Говоря о причинах и условиях совершения преступного поставления в опасность заражения и заражения ВИЧ-инфекцией, отметим, что они неоднозначны, своеобразны, хотя во многом схожи с общими причинами совершения преступлений против жизни и здоровья человека. Прежде чем приступить к их изучению, следует выделить три взаимосвязанных, но совершенно не тождественных уровня:

- изучение общесоциальных причин и условий преступного поставления в опасность заражения и заражения ВИЧ-инфекцией;

- изучение причин и условий преступного поставления в опасность заражения или заражения ВИЧ-инфекцией, характерных для определенных социальных групп и коллективов (медицинские работники; лица, употребляющие наркотические средства; заключённые; лица с нетрадиционной сексуальной ориентацией; женщины, занимающиеся проституцией);

- изучение конкретной жизненной ситуации как событий или состояний, вызывающих решимость совершить общественно опасные деяния, способствующие или препятствующие ему. 
Общесоциальные факторы, детерминирующие показатели преступности в целом как социального явления, едины для всех видов преступности. Одними из них являются факторы экономического характера [16, с. 5]: социальные и экономические проблемы семьи, высокий уровень безработицы, множество бытовых неурядиц и др.

Распространение вируса иммунодефицита человека является одной из главных проблем современности. Для определения причин и условий преступного поставления в опасность заражения или заражения ВИЧинфекцией на групповом уровне необходимо обладать специальными познаниями в различных областях [17], в частности, быть осведомлённым о способах передачи данного вируса.

В настоящее время доказано существование пяти путей передачи ВИЧинфекции [18]:

- половой путь - это любые виды секса (классический, вагинальный; анальный; оральный; орогенитальный; групповой);

- внутриутробный путь передачи инфекции (через плацентарную кровь от матери к плоду; от матери к новорожденному - его инфицирование при родах);

- парентеральный путь (когда инфекция попадает непосредственно в кровь, на слизистую и т.д., минуя механизмы защиты организма). Самые распространённые парентеральные пути - внутривенная инъекция нестерильным шприцем и переливание крови. Более редкие - передача инфекции через ранения;

- другие пути передачи (кровь и многие внутренние органы).

Примечательно, что для ВИЧ-инфекции парентеральный путь является наиболее распространённым. В ходе исследования было выявлено, что ВИЧ в среду наркоманов попал в 1996 г. Данный факт сразу негативным образом сказался на увеличении количества заражённых лиц за год в 6 раз (1995 г. 1200 чел., 1996 г. - 7800 чел.). Эта тенденция сохраняется до сих пор. Так, среди впервые выявленных в 2015 г. ВИЧ-позитивных с установленными факторами риска заражения 53,6\% инфицировались при употреблении наркотиков нестерильным инструментарием (парентеральный путь), 44,0\% при гетеросексуальных контактах (половой путь), 1,5\% - при гомосексуальных контактах (половой путь), 0,9\% составляли дети, инфицированные от матерей во время беременности, родов и при грудном вскармливании [19].

Парентеральный путь является главным способом распространения вируса иммунодефицита человека в местах лишения свободы. По состоянию на 
1 января 2019 г. в местах лишения свободы содержалось 61417 человек ВИЧинфицированных, что составляет 7\% от общей численности инфицированных данным вирусом по всей стране. ВИЧ-инфекцией поражены каждый 10-й мужчина и каждая пятая женщина, содержащиеся в учреждениях уголовноисполнительной системы [20]. Как справедливо заметил А.К. Теохаров, необходимо помнить, что ВИЧ появился именно среди гомосексуалистов. Так, в 2001 г. в исправительной колонии № 4 Нижнекамска в течение двух месяцев было выявлено 246 случаев ВИЧ-инфекции. Проверкой было установлено, что эпидемия началась с заключённого, который использовался в качестве пассивного сексуального партнёра другими осуждёнными, которые далее парентерально употребляли наркотические вещества одним и тем же шприцем, что привело к инфицированию почти $14 \%$ от общего количества всех заключённых [21, с. 115-116].

В юридической практике можно встретить случаи заражения ВИЧинфекцией в результате пренебрежения медицинскими работниками технологии стерилизации оборудования либо при нарушении правил переливания крови. Подобные случаи носят высоколатентный характер. Таким образом, фактором поставления в опасность заражения либо заражения ВИЧинфекцией в медицинской сфере выступает профессиональная небрежность данного персонала.

Необходимо отметить, что причины и условия индивидуального преступного поведения являются частью общего причинного комплекса преступности. Анализ имеющейся между ними связи считается важной криминологической задачей [22].

Согласно криминологической доктрине, в случае, если причины преступности в общем обусловлены противоречиями социальной среды, то причины и условия совершения конкретного преступления в большей степени подвержены воздействию конкретного окружения человека и той микросреды, в какой происходит его формирование [23, с. 10-18]. Более того, особенности самой личности влияют на детерминацию преступного поведения.

Следует согласиться с мнением криминологов, считающих, что личность преступника определяется как личность человека, который совершил преступление вследствие присущих ему психологических особенностей, антиобщественных взглядов, отрицательного отношения к нравственным ценностям и выбора общественно опасного пути для удовлетворения своих 
потребностей или непроявления необходимой активности в предотвращении отрицательного результата [24, с. 110].

Вопрос изучения личности ВИЧ-инфицированного, совершившего преступление, в криминологической науке рассматривался неоднократно [25]. Анализируя эти исследования, можно охарактеризовать личность ВИЧинфицированного преступника следующим образом.

Социально-психологические свойства ВИЧ-инфицированного преступника включают особенности его поведения, потребностей и мотивов. Мотив преступника продиктован его интересами, стремлениями, проявлением воли. Прослеживается чёткая связь между наличием вируса иммунодефицита человека в организме инфицированного и вызвавшей его депрессией, агрессией, психическим расстройством. В результате психологических изменений возможно проявление такого типичного поведения, как: отрицание факта заболевания, озлобленность и желание нанести в связи с этим вред другим, суицидальные мотивы, страх смерти, беспокойство, отчуждение. Психические расстройства проявляются в связи с неврологическими изменениями центральной нервной системы, а также в результате осознания смертельного исхода болезни и дискриминацией со стороны общества («стигмы»).

В этой связи особого внимания заслуживает следующий вывод профессора Ю.М. Антоняна о том, что «отсутствие надлежащих семейных контактов особенно пагубно для девочек. Во-первых, почти все отвергнутые семьей девочки слишком рано начинают половую жизнь, становятся лёгкой сексуальной добычей более взрослых парней, быстро деморализуются; их интимные связи приобретают беспорядочный характер. Во-вторых, оторвавшись от семьи, школы, выйдя за пределы нормального человеческого общения, таким девушкам очень трудно, а иногда невозможно вернуться к обычной жизни, завоевать уважение окружающих. Социальное клеймение (стигмация) женщин обычно оказывается намного более стойким и губительным, чем у мужчин. Особенно трагично складывается судьба бродяг, проституток, наркоманок, алкоголичек, а также тех, кто связал себя с профессиональными преступниками» [26]. Сказанное совершенно справедливо и для преступного инфицирования вирусом иммунодефицита человека.

В судебной практике встречаются случаи намеренного, осознанного заражения ВИЧ-инфекцией большого количества людей, продиктованные 
вышеуказанными мотивами. Встречаются поведенческие стереотипы безразличного отношения ко всему. Такое поведение характерно для лиц, употребляющих наркотики инъекционным путём. Данные психологические особенности характерны и для ВИЧ-инфицированных осуждённых, положение которых усугубляется условиями изоляции.

Так, например, в 2008 г. в Новомосковском районе Тульской области осуждена несовершеннолетняя, больная ВИЧ-инфекцией, которая заведомо поставила двух лиц в опасность заражения этим заболеванием. Девушка с 2006 г. состоит на учёте с диагнозом «ВИЧ-инфекция третьей стадии», о наступлении уголовной ответственности за заведомое поставление в опасность заражения ВИЧ-инфекцией предупреждена под расписку. Однако, в нарушение данного запрета, 17-летняя девушка в октябре 2007 г. совершила половые акты с лицами мужского пола, не предупредив их о наличии у неё данного заболевания. При назначении наказания суд учёл её несовершеннолетний возраст, отсутствие родителей, совершение преступления впервые и назначил наказание в виде штрафа в размере 1500 руб. [27]

Данный пример позволяет говорить о такой самостоятельной субъективной причине, характеризующей личность ВИЧ-инфицированного преступника, как половая деморализация.

Социально-демографические особенности ВИЧ-инфицированных преступников исследованы теоретиками [28] и характеризуются тем, что их подавляющая часть - это молодые мужчины (более 80\%). По возрастному составу треть ВИЧ-инфицированных преступников - в возрасте от 20 до 24 лет, чуть меньше трети - от 25 до 40 лет. Рассматриваемая категория преступников по семейному положению, как правило, в браке не состоит (86\% мужчин холосты; 70\% женщин не замужем). Образовательный уровень ВИЧинфицированных преступников остается достаточно низким. В основном, это люди с неполным средним и средне-специальным образованием. Соответственно, уровень образования сказывается на трудовой деятельности ВИЧ-инфицированных преступников, среди которых почти треть безработные. По некоторым данным доход таких преступников не превышает 7000 рублей в месяц [29, с. 108]. Низким материальным положением обусловлены виды преступлений, которые совершают ВИЧ-инфицированные лица: хищения (более 60\%), наркопреступления (30\%), преступления против личности (около 10\%). На основании изложенного, к основным причинам, 
побудившим ВИЧ-инфицированных лиц совершить преступления, можно отнести: алкоголизм либо наркомания, низкое материальное положение, низменные побуждения (месть), а также половая деморализация.

Проанализировав существенные криминологические признаки ВИЧинфицированных преступников, можно выделить самостоятельный тип, который обусловлен соответствующей инфекцией/заболеванием. Для такого преступника характерны агрессивность, конфликтность, высокий уровень криминальной активности (среди этой категории лиц очень высок уровень рецидива), а также отчуждение от общества. Более того, психологи утверждают, что для личности ВИЧ-инфицированных свойственны различные психические отклонения, вызванные осознанием своего статуса.

Исключением из вышеназванной характеристики является личность преступника, совершившего преступное поставление в опасность заражения либо заражение ВИЧ-инфекцией в результате выполнения своих профессиональных обязанностей. Характеризуя признаки данной личности, отметим, что в большинстве случаев это лица, имеющие среднее специальное либо высшее образование соответствующего профиля, в возрасте от 23 лет, профессиональная деятельность которых связана с кровью и биологическими материалами, содержащими вирус иммунодефицита человека. Чаще всего инфицирование данными лицами совершается в результате пренебрежения установленными правилами безопасности.

При определении причин и условий конкретного преступления необходимо выделять те механизмы, которые являются едиными для всех преступлений данного вида. Более того, необходимо признать обоснованной позицию В.А. Номоконова о том, что в криминологии пока нет общепризнанной концепции, раскрывающей причины, лежащие в основе каждого конкретного преступления. Тем не менее, действующее законодательство обязывает правоохранительные органы по каждому уголовному делу устанавливать причины и условия конкретного преступления [30, c. 99].

Исходя из изложенного, наибольший интерес вызывает выработанное криминологами понятие конкретной жизненной ситуации. Конкретная жизненная ситуация, складывающаяся до и в момент совершения преступления, может играть решающую роль в преступном деянии, хотя не следует забывать, что «никакая жизненная ситуация не приводит фатально, 
минуя волю и сознание субъекта, к совершению преступления. Основное внимание акцентируется на взаимодействии, взаимовлиянии конкретной жизненной ситуации и личности, её социальных, социально-психологических и индивидуально-психологических особенностей» [31, с. 4].

Как справедливо отмечает Р.В. Жубрин, изучение детерминант преступного поведения конкретного человека значимо для установления формы вины лица, индивидуализации наказания, смягчающих и отягчающих обстоятельств [32, с. 174]. Тем не менее, выявление причин и условий индивидуального поведения преступника на практике нередко сталкивается с определёнными трудностями. Как известно, человек - существо социальное, на его поведение воздействует множество факторов, которые в процессе мыслительной и чувственной деятельности преображаются в определенные поведенческие установки. При этом выявить конкретный фактор, повлиявший на преступное поведение, порой невозможно. Более того, применительно к рассматриваемым преступлениям, практика применения ст. 122 УК РФ не содержит подобные данные, как и данные, характеризующие личности преступника.

Однако эти сложности не свидетельствуют о невозможности выделения детерминант индивидуального преступного поведения, поскольку конкретные детерминанты преступления выступают относительно неделимым элементом системы причин и условий преступности. Именно по этой причине общесоциальные детерминанты преступного поставления в опасность заражения или заражения ВИЧ-инфекцией в большинстве случаев имеют общие черты с причинами и условиями индивидуального преступного поведения. Следовательно, к числу детерминант преступного поставления в опасность заражения или заражения ВИЧ-инфекцией относятся следующие:

- обострение социально-экономических противоречий в период сложной экономической ситуации;

- пренебрежение как правилами поведения в обществе, так и уголовноправовыми нормами, отсутствие комплексной идеологии здоровьесбережения;

- духовный кризис общества, рост алкоголизации и наркотизации населения.

Социально-экономические причины и условия совершения преступного поставления в опасность заражения или заражения ВИЧ-инфекцией являются первостепенными. Только при достойной жизни в экономическом смысле 
возможно развитие тех качеств личности, которые свойственны человеку чистоплотному во всех отношениях. Аналогичную точку зрения разделяют и медики, отмечая, что проблема борьбы с распространением ВИЧ, к сожалению, носит не столько медицинский, сколько социальный характер. К негативным экономическим условиям, способствующим совершению преступлений (в том числе и преступного поставления в опасность заражения или самого заражения ВИЧ-инфекцией), следует отнести безработицу. Так, по данным специалистов она особенно высока в малых городах (особенно на востоке России), при этом данный показатель выше в 19 раз, чем уровень безработицы в европейской части России. Более того, высок удельный вес убыточных предприятий. Например, в Восточной Сибири таких предприятий 60\%, а в московском регионе - 30\%. Люди психологически оказались не готовы к такому резкому расслоению общества, что приводит к формированию противоправного поведения. Более того, как справедливо утверждает В.А. Номоконов, в нашей стране наблюдается глубокое социальное расслоение, которое не имеет аналогов в мире. Так, за 20 лет в постсоветской России была выращена сотня долларовых миллиардеров - больше, чем во всей Европе. По этому показателю Россия находится в тройке мировых лидеров, а по т.н. «индексу развития человеческого потенциала» - всего лишь на 70 месте. Основными средствами производства у нас владеет 1\% населения [33]. Сказанное свидетельствует о социально-экономическом неблагополучии населения, что в свою очередь приводит к падению нравственности.

Нравственно-психологический климат в обществе - следующий фактор, который необходимо анализировать при любых антисоциальных проявлениях, тем более, в сфере интимных отношений.

Пропаганда секса, порнографии, насилия, широкая нелегальная продажа интимных услуг, увеличивающееся потребление алкоголя и наркотиков (в том числе подростками и молодёжью), беспорядочные сексуальные связи без применения средств индивидуальной защиты от ВИЧ-инфекции, - всё это сводит на нет любые усилия медиков. Подобного мнения в своих диссертационных исследованиях придерживаются Е.А. Иерусалимская, А.В. Пантелеев, А.К. Теохаров [34].

В этой связи особое внимание нужно уделять комплексной идеологии здоровьесбережения, которая способна создать главные ориентиры у населения страны, позволяющие сформировать гармоничную среду жизнедеятельности 
многих поколений людей. Ту атмосферу, в которой играли бы значительную роль идеалы крепкой семьи, уважения и любви, духовности, доброты, заботы о своём здоровье и здоровье окружающих.

Идеологическая основа неразрывно связана с правом, поскольку основы регулирования политики и идеологии основаны на правовых средствах. Следует согласиться с мнением профессора Т.Н. Радько, который пишет о том, что «помимо юридического, право осуществляет ещё и идеологическое, воспитательное воздействие, которое нельзя относить к регулирующему. В этой связи представляется теоретически обоснованным мнение, что правовое регулирование охватывает собой все формы влияния права на общественную жизнь» [35, с. 99].

Размышляя о нравственно-психологическом климате в обществе более пятнадцати лет тому назад, профессор В.Н. Кудрявцев высказал следующее суждение: «... необходимо создавать и развивать на современном уровне систему профилактики преступлений. Её рациональные основы были заложены в нашей стране более полувека назад. Необходимо на новой, добровольной основе восстановить и укрепить связь между правоохранительными органами и населением, вернуть утраченное к ним доверие со стороны граждан. В первую очередь, забота государства и общественности касается безнадзорных, «трудных», «запущенных» детей и подростков, а также определённых групп населения (безработные, мигранты, алкоголики, наркоманы и др.)» [36, с. 111]. Сказанное актуально и в настоящее время.

Радикальные изменения, происходящие в России, при отсутствии психологических и духовных компенсаций могут оказывать разрушительное воздействие на семью, трансформируя одновременно и ценностную структуру взаимоотношений полов. Как поясняет российский социолог Н.Е. Покровский, «речь идет о стремительном отходе от традиционных норм и ценностей, характерных в прошлом для российской социокультурной парадигмы с её акцентом на «духовность» (нематериальность), жертвенность, допустимость страдания, коллективизм». При всём том, что жертвенность и допустимость страдания вряд ли заслуживают положительного отношения, они должны искореняться очень осторожно. Если, конечно, такая цель будет поставлена жизнью [37, с. 175].

Характеристика современной семьи, по мнению учёных, состоит в следующих особенностях: изначальное интерактивное дистанцирование 
супругов друг от друга, связанное с ростом их индивидуализма; предельная рационализация всех отношений, включая интимные; внедрение открыто или скрыто контрактных (договорных) взаимодействий, касающихся прежде всего материальных аспектов отношений между полами и приобретающих доминирующее значение [38, с. 175]. Таким образом, в современной семье происходит смена ценностей, причем идеологические ориентиры ошибочно принимают за нравственные. При такой смене могут резко активизироваться некоторые формы девиантного поведения, приводящие к «стиранию» нравственных границ, которые впоследствии провоцируют преступное инфицирование, передаваемое половым путём.

Разумеется, в данном аспекте следует говорить о половом воспитании. Конкретизируя задачи полового воспитания, к ним можно отнести следующие: формирование высоконравственных отношений между мальчиками и девочками в этическом и моральном плане; поэтапную их подготовку с самого раннего детства (в семье, дошкольных учреждениях, школе) к будущей семейной жизни; выполнению ими социальных обязанностей мужа, жены, матери, отца; воспитание родительских чувств, ответственности за будущие поколения; формирование правильного поведения в личных, интимных отношениях.

Как справедливо отмечает одна из известных психологов, занимающаяся изучением причин девиантного поведения, М.И. Арсеньева, «половое поведение социально регулируется. На этом основана и уголовная ответственность за половые преступления» [39]. Подобное мнение высказывал еще в XIX в. известный юрист П.И. Люблинский. Он писал, что в громадном большинстве случаев половая деятельность человека подчинена контролю сознания и способна поддаваться влиянию социальных сдержек. Система социальных сдержек, вырабатываемых обществом, включающих правила приличия, этикета, моральное сознание и уголовное наказание, призвана регулировать поведение в области половых отношений [40].

Кроме того, нельзя не согласиться с Е.С. Надтокой, которая, проведя исследование преступлений против здоровья, отмечает: «... правовая пропаганда и агитация, правовое воспитание и правовое обучение также являются важными и обязательными стратегическими линиями государства. Они строго зависимы от духовного развития общества и потому должны претворяться в жизнь параллельно с возрождением нравственных начал. 
Данное исследование свидетельствует, что 7,2\% осуждённых не знали, что совершают преступление, $15,8 \%$ не думали о последствиях своих действий. Были уверены, что совершают преступление, но рассчитывали остаться безнаказанными 28,1\% респондентов; 20,8\% надеялись на мягкую меру наказания» [41].

Мы вполне согласны с убеждением данного автора в том, что знание права является необходимым, но не достаточным условием для обеспечения правомерного поведения. В условиях низкого нравственного потенциала общества, как справедливо указывает Е.С. Надтока, требования закона, как правило, не принимаются его членами в качестве глубокого личного убеждения. Сдерживать противоправное поведение может только осведомлённость о запрете определенных действий и страх перед адекватно суровым наказанием.

Нельзя не увидеть причины и условия совершения преступного поставления в опасность заражения или заражения ВИЧ-инфекцией при таких формах антисоциального поведения, как алкоголизм, наркомания, токсикомания.

Профессор О.В. Старков отмечает связь между наркотизмом, пьянством и преступностью, которые выражаются как массовое, устойчивое социальное отклонение наркотизм, пьянство и преступность имеют однозначные и одноуровневые общесоциальные причины и условия. Несомненно, в данную взаимосвязь и под общую детерминацию подпадает и распространение ВИЧинфекции; социальные отклонения являются фоновыми для преступности явлениями, то есть сопутствующими преступности, создающими для неё почву, соответствующую среду, как бы предоставляющую возможность проявиться преступности» [42, с. 214].

Вакуум воспитательного семейного воздействия на личность заполняется другими элементами контактного общения. Огромное влияние на нравственное, культурное и психическое здоровье населения имеют средства массовой информации, особенно телевидение. В связи с этим было бы целесообразно усилить пропагандистскую работу в области профилактики заболеваний, передаваемых половым путём.

Таким образом, проведённое исследование детерминант преступного поставления в опасность заражения или заражения ВИЧ-инфекцией позволило выделить основные группы причин и условий таких преступлений: 
а) общесоциальные факторы, детерминирующие показатели преступности в целом, как социального явления, едины для всех видов преступности. Одними из них являются факторы экономического характера: социальные и экономические проблемы семьи, высокий уровень безработицы, множество бытовых неурядиц; обострение социально-экономических противоречий в период сложной экономической ситуации; пренебрежение как правилами поведения в обществе, так и уголовно-правовыми нормами, отсутствие комплексной идеологии здоровьесбережения; духовный кризис общества, рост алкоголизации и наркотизации населения.

б) к причинам и условиям преступного поставления в опасность заражения или заражения ВИЧ-инфекцией, которые характерны для определённых социальных групп и коллективов (медицинские работники; лица, употребляющие наркотические средства; заключённые; лица с нетрадиционной сексуальной ориентацией; женщины, занимающиеся проституцией и др.), следует отнести: алкоголизм либо наркоманию, низкое материальное положение, низменные побуждения (месть), половую деморализацию, а также небрежное (в том числе и безответственное) отношение к своим профессиональным обязанностям.

в) к числу детерминант индивидуального преступного поведения при поставлении в опасность заражения или заражения ВИЧ-инфекцией относятся следующие: социальное и экономическое неблагополучие ВИЧинфицированных лиц, совершивших поставление в опасность заражения или заражение ВИЧ-инфекцией третьих лиц, а также низкий уровень нравственных и идеологических ценностей данных индивидов.

г) личность ВИЧ-инфицированного преступника имеет свой самостоятельный тип. Для такого преступника характерна агрессивность, конфликтность, высокий уровень криминальной активности (среди этой категории лиц очень высок уровень рецидива), а также отчуждение от общества и различные психические отклонения, вызванные осознанием своего статуса. Исключением из названной характеристики является личность преступника, совершившего преступное поставление в опасность заражения либо заражение ВИЧ-инфекцией в результате выполнения своих профессиональных обязанностей. Это лица, имеющие среднее специальное либо высшее образование соответствующего профиля, в возрасте от 23 лет, профессиональная деятельность которых связана с кровью и биологическими 
материалами, содержащими вирус иммунодефицита человека. Чаще всего инфицирование данными лицами совершается в результате пренебрежения установленными правилами безопасности.

\section{Список литературы}

1. Дагель, П.С. Причины преступности в СССР и причины индивидуального преступного поведения / П.С. Дагель // Проблемы причинности в криминологии и уголовном праве : межвузовский тематический сборник. - Владивосток : Изд-во Даньневост. ун-та., 1983. - С. 22-37.

2. Долгова А.И. Криминология. [Электронный ресурс] // URL : http://www.be5.biz/pravo/k003/06.htm (дата обращения : 20.02.2021).

3. Кудрявцев, В.Н. Причинность в криминологии / В.Н. Кудрявцев. - М. : Юрид. лит., 1968. - 176 с.; Кузнецова, Н.Ф. Проблемы криминологической детерминации / Н.Ф. Кузнецова. - М. : Изд-во Моск. ун-та, 1984. - С. 48; Номоконов, В.А. Методологические основы изучения причин преступного поведения / В.А. Номоконов. - Владивосток : Изд-во Дальневост. ун-та, 1986. С. 76; Ломброзо, Ч. Преступление. Новейшие успехи науки о преступнике / Ч. Ломброзо. - М. : ИНФРА-М, 2004. - С. 8; Глебов, Д.А. Налоговые преступления и налоговая преступность / Д.А. Глебов, А.И. Ролик. - СПб. : Издательство Р. Асланова «Юридический центр Пресс», 2005. - С. 173.

4. Криминология / под общ. ред. докт. юрид. наук, проф. А.И. Долговой. - М. : НОРМА, 2002. -784 c.

5. Утевский, Б.С. Советская исправительно-трудовая политика : учебник / Б.С. Утевский / под общ. ред. Б. С. Ошеровича. - М. : Гос. изд-во Советское законодательство, 1934. - 253 с.

6. Кузнецова, Н.Ф. Проблемы криминологической детерминации / Н.Ф. Кузнецова. - М. : Изд-во Моск. ун-та, 1984. - 208 с.

7. Криминология : учебник для академического бакалавриата Ю.М. Антонян. - 3-е изд., перераб. и доп. - М. : Издательство Юрайт, 2016. $388 \mathrm{c}$.

8. Шнайдер, Г. Й. Криминология / Г. Й. Шнайдер. - М. : Универс, 1994. $-504 \mathrm{c}$.

9. п. 11 Об утверждении плана мероприятий по реализации в 2016-2020 годах Концепции демографической политики Российской Федерации на период до 2025 года : Распоряжение Правительства Российской Федерации от 14 
апреля 2016 г. № 669-р / Распоряжение Правительства Российской Федерации. [Электронный pecypc] // URL : http:// www.pravo.gov.ru (дата обращения : 13.02.2021).

10. Криминология : учебник для академического бакалавриата / Ю.М. Антонян. - 3-е изд., перераб. и доп. - М. : Издательство Юрайт, 2016. $388 \mathrm{c}$.

11. Шаргородский, М.Д. Преступность, её причины и условия в социалистическом обществе / М.Д. Шаргородский // Преступность и её предупреждение. - Л. : Лениздат, 1966. - С. 20-58.

12. Криминология. М., 1968. С. 293-294 (автор главы Г.М. Миньковский).

13. Кузнецова, Н.Ф. Проблемы криминологической детерминации / Н.Ф. Кузнецова. - М. : Изд-во Моск. ун-та, 1984. - С. 44; Преступность как социальное явление. Лекции по криминологии / Стручков Н.А. - Л., 1979. - С. 29 и др.

14. Кудрявцев, В.Н. Причинность в криминологии / В.Н. Кудрявцев. - М. : Юрид. лит., 1968. - 176 с.; Волошин, Л.А. О системном подходе к изучению сущности преступности / Л.А. Волошин // Вопросы борьбы с преступностью. 1972. - № 15. - С. 13-23; Криминология : учебник для вузов / под ред. А.И. Долговой. - М. : Юристъ, 1997. - С. 208.

15. Гилинский Я.И. Criminology today // Русский народный сервер против наркотиков «НарКом». [Электронный ресурс] // URL : http://www.narcom.ru/law/ system/25.html\#top (дата обращения : 13.02.2021).

16. Лунеев, В.В. Тенденции современной преступности и борьба с ней в России / В.В. Лунеев // Государство и право. - 2004. - № 1. - С. 5-18.

17. Воронин, Р.М. Психологические особенности ВИЧ-инфицированных осужденных // Электронный научный журнал «Личность в меняющимся мире : здоровье, адаптация, развитие». - 2014. - № 3 (6). - С. 68-75; Воронин, Р.М. Основные направления в медицинской психологии в исправительных учреждениях // Прикладная юридическая психология.-2014.-№ 1.-С. 112-117.

18. Пути передачи ИППП. Государственное учреждение здравоохранения Ставропольского края «Краевой клинический кожно-венерологический диспансер». [Электронный ресурс] // URL : http://stkvd.ru/ippp_puti_per.html (дата обращения : 13.02.2021).

19. Справка ВИЧ-инфекция в Российской Федерации на 31 декабря 2015г. // Федеральный научно-методический центр по профилактике и борьбе со 
СПИДом ФБУН Центрального НИИ эпидемиологии Роспотребнадзора (на основании данных, предоставленных территориальными центрами по профилактике и борьбе со СПИД). [Электронный ресурс] // URL : http:/hivrussia.ru (дата обращения : 13.02.2021).

20. Во ФСИН назвали число ВИЧ-инфицированных среди осужденных в России // TACC информационное агентство. [Электронный ресурс] // URL : https://tass.ru/obschestvo/6331063 ?keepThis=true\&TB_iframe $=$ true\&height $=500 \& \mathrm{w}$ $\mathrm{idth}=1100 \&$ caption=TACC (дата обращения : 26.02.2021);

21. Теохаров, А.К. Противодействие заражению инфекционными заболеваниями: уголовно-правовой и криминологический аспекты : дис. ... канд. юрид. наук : 12.08.00 / Теохаров Александр Константинович. - Омск, 2013. - 221 с.; Адылин, Д.М. Некоторые пенитенциарные детерминанты, влияющие на преступность осуждённых, связанную с заражением ВИЧинфекцией в местах лишения свободы // Вестник Самарского юридического института. - 2018. - № 4 (30). - С. 9-13.

22. Бурлаков, В.Н. Криминология: Краткий курс. Преступность как свойство общества / В.Н. Бурлаков, Д.А. Шестаков. - СПб. : Изд-во «Лань», 2001. - С. 264 // Правоведение. СПб. : Изд-во С. Петербург. ун-та, 2002, - № 3. - C. 271-273.

23. Сахаров, А.Б. Актуальные вопросы учения о личности преступника / А.Б. Сахаров // Теоретические проблемы учения о личности преступника. Сборник научных трудов. - М. : Изд-во Всесоюз. ин-та по изуч. причин и разраб. мер предупреждения преступности, 1979. - С. 10-18.

24. Эминов, В.Е. Личность преступника и её формирование / В.Е. Эминов, Ю.М. Антонян // Актуальные проблемы российского права. 2015. - № 1 (50). - С. 107-112.

25. Зайцева, И.В. Правовые и организационные исполнения наказания в виде лишения свободы в отношении ВИЧ-инфицированных осуждённых : дис. ... канд. юрид. наук : 12.00 .08 / Зайцева Ирина Владимировна. - М., 2002. 188c.; Громов, В.Г. СПИД и личность преступника / В.Г. Громов // Организованная преступность, миграция, политика. - М. : Российская криминологическая ассоциация. - 2002. - С. 120-126; Никитин, Д.А. Личность ВИЧ-инфицированного осуждённого: криминологический и социальнодемографический аспекты // Человек : преступление и наказание. - 2008. - № 4. - С. 106-108; Дьяченко, А.П., Датий, А.В., Митропольская, К.В. 
Характеристика ВИЧ-инфицированных осуждённых мужчин, отбывающих наказание в исправительных учреждениях ФСИН России // Уголовноисполнительное право. - 2010. - № 1. - С. 71-74; Никитин, Д.А. Криминологическая характеристика и предупреждение преступлений, совершаемых ВИЧ-инфицированными : дис. ... канд. юрид. наук : 12.00 .08 / Никитин Дмитрий Алексеевич. - Рязань, 2010. - 194 с.; и др.

26. Криминология : учебник / под ред. В. Н. Кудрявцева, В. Э. Эминова. M. : Юристъ, 1997. [Электронный ресурс] // URL : http://www.pravo.vuzlib.org/ book_z1477_page_11.html (дата обращения : 27.02.2021).

27. СПИД и уголовная ответственность // Тульский городской портал vTule.ru - 03 b.yz 2008. [Электронный pecypc] // URL : http://vTule.ru /events/e10125271/ (дата обращения : 27.02.2021).

28. Воронин, Р.М., Датий, А.В., Юсупов, Р.Ш. Уголовно-исполнительная характеристика ВИЧ осужденных женщин // Уголовно-исполнительное право. 2012. - № 2. - С. 79-80; Теохаров А.К., Бойко, О.А., Ревягин, А.В. Характеристика личности ВИЧ-инфицированного осужденного // Психопедагогика в правоохранительных органах. - 2018. - № 3 (74). - С. 103 106; Кудрявцев, А. В. Проблемы предупреждения совершения преступлений ВИЧ-инфицированными осужденными в исправительных учреждениях // Пенитенциарное право: юридическая теория и правоприменительная практика. - 2020. - № 1 (23). - С. 83-87; и др.

29. Никитин, Д.А. Личность ВИЧ-инфицированного осуждённого: криминологический и социально-демографический аспекты // Человек : преступление и наказание. - 2008. - № 4. - С. 106-108.

30. Номоконов, В.А. Преступное поведение: детерминизм и ответственность / В.А. Номоконов. - Владивосток : Издательство Дальневосточного университета, 1989. - 160 с.

31. Роль конкретной жизненной ситуации в совершении преступления. Учебное пособие / Ю.М. Антонян. - М. : Изд-во Акад. МВД СССР, 1973. - 71 с.

32. Криминология. Общая часть : учебник для академического бакалавриата / под общ. ред. О. С. Капинус. - М. : Издательство Юрайт, 2016. $303 \mathrm{c.}$

33. Номоконов, В.А. Особенности причинного комплекса преступности в современной России / В.А. Номоконов // Вестник Нижегородской правовой академии. - 2016. - № 9. - С. 70-75. 
34. Иерусалимская, Е.А. Заражение венерическими болезнями : уголовноправовые и криминологические аспекты : автореф. дис. ... канд. юрид. наук : 12.00.08 / Иерусалимская Елена Александровна. - Ставрополь, 2002. - С. 25; Пантелеев, А.В. Криминалистическая характеристика преступлений и её информационно-методическая роль в раскрытии, расследовании преступлений, связанных с заражением венерической болезнью и ВИЧ-инфекцией : автореф. дис. ... канд. юрид. наук : 12.00 .09 / Пантелеев Андрей Владимирович. Екатеринбург, 2006. - С. 10; Теохаров, А.К. Противодействие заражению инфекционными заболеваниями : уголовно-правовой и криминологический аспекты : автореф. дис. ... канд. юрид. наук. - Омск. - 2013. - С. 9.

35. Радько, Т.Н. Теория государства и права: учебник для вузов по специальности Юриспруденция / Т.Н. Радько. - М. : Проспект, 2010. - 744 с.

36. Кудрявцев, В.Н. Генезис преступления: опыт криминологического моделирования: учеб. пособие / В.Н. Кудрявцев. - М. : Инфра-М, Изд. дом «Форум», 1998. - 216 с.

37. Покровский, Н.Е. Глобализационные процессы и возможный сценарий их воздействия на российское общество / Н.Е. Покровский // Город и село: перспектива структурного воссоединения. - М. : СоПСо, 2004. - С. 175.

38. Покровский, Н.Е. Глобализационные процессы и возможный сценарий их воздействия на российское общество / Н.Е. Покровский // Город и село: перспектива структурного воссоединения. - М. : СоПСо, 2004. - С. 175.

39. Арсеньева, М.И. Особенности формирования противоправного поведения женщин и некоторые аспекты его предупреждения / М.И. Арсеньева, В.Л. Серебрякова // Вопросы борьбы с преступностью. - М. : Юрид. лит., 1982. - . Вып. 36. - С. 15-26.

40. Петров Э.И. Криминология. [Электронный ресурс] // URL : http://law.edu.ru/book/book.asp?bookID=1222898 (дата обращения : 27.02.2021).

41. Надтока E.C. Криминологическая характеристика преступлений против здоровья и их предупреждение : автореф. дис. ... канд. юрид. наук. Ростов н/Д, 2005. [Электронный ресурс] // URL : http://web1.law.edu.ru/script/ cntSource.asp?cntID=100139367 (дата обращения : 27.02.2021).

42. Старков, О.В. Криминопенология / О.В. Старков. - М. : Экзамен, 2004. $-480 \mathrm{c}$. 
УДК 338.45.01

\title{
НЕКОТОРЫЕ РЕЗУЛЬТАТЫ РЕАЛИЗАЦИИ НАЦИОНАЛЬНОГО ПРОЕКТА «БЕЗОПАСНЫЕ И КАЧЕСТВЕННЫЕ АВТОМОБИЛЬНЫЕ ДОРОГИ» В ЧЕЧЕНСКОЙ РЕСПУБЛИКЕ ЗА 2019-2020 ГОДЫ
}

\author{
Идигова Лалита Мусаевна \\ д.э.н., профессор \\ Чеченский государственный университет \\ Газиева Лейла Руслановна \\ к.э.Н., доцент \\ Чеченский государственный университет \\ Хаджиева Марьям Маулдыновна \\ К.Э.Н. \\ Академия наук Чеченской Республики
}

Аннотация: В данном разделе монографии изучена и проанализирована транспортная инфраструктура, которая, по мнению авторов является одной из важнейших подсистем экономики. Авторами отмечено, что современная рыночная экономика выдвигает на первый план разработку проблем связанных c формированием региональной транспортной инфраструктуры. Для их решения необходимо провести исследование структуры и конфигурации транспортной сети, что предполагает разработку модели организации территориальной транспортной инфраструктуры

Авторами в проведен анализ реализации национального проекта «Безопасные и качественные автомобильные дороги» на территории Чеченской Республики.

Вывод: влияние транспортной составляющей на социальноэкономическое развитие региона, на размещения производства в Чеченской Республике является существенным, а иногда ключевым фактором. В силу этого, в ряде регионов России, в Чеченской Республики в том числе, динамичное и сбалансирование развитие производственных комплексов, рациональное использование природных, политических, экономических и трудовых ресурсов практически полностью зависит от уровня развития дорожно-транспортного комплекса, его основных объектов и элементов.

Ключевые слова: национальный проект, автомобильные дороги, регион. 


\title{
SOME RESULTS OF THE IMPLEMENTATION \\ OF THE NATIONAL PROJECT «SAFE AND HIGH-QUALITY ROADS» IN THE CHECHEN REPUBLIC FOR 2019-2020
}

\author{
Idigova Lalita Musaevna \\ Gazieva Leila Ruslanovna \\ Hadjiev Maryam Maulenovna
}

\begin{abstract}
This section of the monograph examines and analyzes the transport infrastructure, which, according to the authors, is one of the most important subsystems of the economy. The authors note that the modern market economy brings to the fore the development of problems related to the formation of regional transport infrastructure. To solve them, it is necessary to conduct a study of the structure and configuration of the transport network, which involves the development of a model for the organization of the territorial transport infrastructure

The authors analyze the implementation of the national project "Safe and Highquality Roads" on the territory of the Chechen Republic.

Conclusion: the influence of the transport component on the socio-economic development of the region, on the location of production in the Chechen Republic is a significant, and sometimes a key factor. Because of this, in a number of regions of Russia, including the Chechen Republic, the dynamic and balanced development of industrial complexes, the rational use of natural, political, economic and labor resources almost completely depends on the level of development of the road transport complex, its main objects and elements.
\end{abstract}

Key words: national project, highways, region.

Транспортная инфраструктура, наличие ее составляющих и уровень ее развития, технико-экономическое состояние играют значительную роль в обеспечении функционирования отраслей народного хозяйства, от оптимальности транспортного обслуживания во многом зависит комплексное развитие и эффективное функционирование производственных комплексов региональной экономики.

Таким образом, функционирование региональной экономики в условиях рынка требуют пересмотра базовых принципов формирования, функционирования и совершенствования дорожно-транспортной 
инфраструктуры, ее основных объектов и элементов, что в конечном итоге потребовало разработки Концепции развития транспортной инфраструктуры Чеченской Республики до 2025 года через рациональное использование элементов транспортной инфраструктуры.

Национальный проект России «Безопасные и качественные автомобильные дороги» имеет важное социально-экономическое значение для экономического развития территорий, снижения аварий на дорогах, повышения мобильности населения, снижения транспортных издержек. Главные цели проекта: к 2024 году увеличить долю региональных дорог, соответствующих нормативным требованиям, снизить количество дорожно-транспортных происшествий (ДТП), внедрить новые требования и стандарты, а также автоматизированные технологии организации дорожного движения и контроля соблюдения правил дорожного движения (ПДД). Паспорт нацпроекта разработан Минтрансом России во исполнение Указа Президента Российской Федерации от 7 мая 2018 года № 204 «О национальных целях и стратегических задачах развития Российской Федерации на период до 2024 года» и включает в себя четыре федеральных проекта: «Дорожная сеть», «Общесистемные меры по развитию дорожного хозяйства», «Безопасность дорожного движения» и «Автомобильные дороги Минобороны России». Срок реализации национального - с декабря 2018 года по декабрь 2024 года. [2] На реализацию данного национального проекта в Чеченской Республике запланировано 6566,0 млн. руб., что составляет $10,1 \%$ от общей суммы финансирования десяти осуществляемых в республике национальных проектов. [1]

Для достижения целей национального проекта «Безопасные и качественные автомобильные дороги» в Чеченской Республике реализуется комплекс программных мероприятий. В 2018 году в республике были сформированы программы дорожной деятельности в рамках федерального проекта «Дорожная сеть». Совместными усилиями федеральных органов исполнительной власти Российской Федерации, органов исполнительной власти республики и органами местного самоуправления намечены мероприятия, инструменты и механизмы обеспечения безопасности дорожного движения - с детализацией на период 2019 - 2021 годов и укрупненно на период 2022 - 2024 годов.

Доля автомобильных дорог общего пользования регионального или межмуниципального, соответствующих нормативным требованиям к 
транспортно-эксплуатационным показателям, в общей протяженности автомобильных дорог общего пользования регионального или межмуниципального, местного значения к 2024 году составит 50\%. [7]

Таблица 1

Протяженность автомобильных дорог Чеченской Республики (км)

\begin{tabular}{|c|c|c|c|c|c|c|c|c|c|}
\hline & 2005 & 2010 & 2013 & 2014 & 2015 & 2016 & 2017 & 2018 & 2019 \\
\hline $\begin{array}{l}\text { Протяженность } \\
\text { автомобильных дорог с } \\
\text { твердым покрытием } \\
\text { (включая дороги необщего } \\
\text { пользования - за } 2010 \text { г. - } \\
\text { включая дороги местного } \\
\text { значения; с } 2013 \text { г. - } \\
\text { включая протяженность } \\
\text { улиц), км }\end{array}$ & 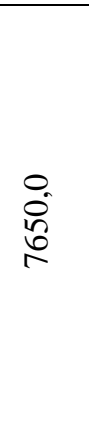 & $\begin{array}{l}0 \\
i \\
\sigma \\
a\end{array}$ & $\begin{array}{l}\bar{i} \\
\bar{\delta} \\
\end{array}$ & 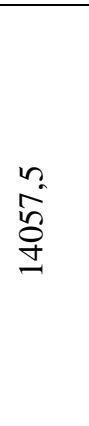 & 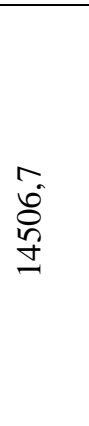 & $\begin{array}{l}\text { ñ } \\
\stackrel{\tilde{g}}{ \pm}\end{array}$ & $\begin{array}{l}\overline{\text { In }} \\
\text { In } \\
\end{array}$ & $\begin{array}{l}0 \\
\text { i } \\
\text { J } \\
\pm\end{array}$ & $\begin{array}{l}\hat{0} \\
\dot{0} \\
\stackrel{+}{ \pm}\end{array}$ \\
\hline
\end{tabular}

Источник: Основные социально-экономические характеристики

Чеченской Республики. Чеченский статистический ежегодник. 2020, С.189

По состоянию на 1 января 2020 протяженность автомобильных дорог регионального значения в Чеченской Республике составляла 3034,2 км, из них 2863,8 км имели твердое покрытие, в том числе 1676,6 км - с асфальтобетонным покрытием, 1187,2 км - с гравийным покрытием, 170,4 км - c естественным покрытием. [7] За пятнадцать лет протяженность автомомбильных дорог с твердым покрытием в республике, по данным Чеченстат, удвоилась (таблица 1).

Согласно отчетам Минавтодор ЧР, в рамках реализации нацпроекта «Безопасные и качественные автомобильные дороги» в Чеченской Республике в 2019 году отремонтировано 53 участка дорог. [9] За 9 месяцев 2020 года завершены ремонтные работы на 27-ми участках автомобильных дорог общей протяженностью 128,9 км, выполнено аварийно-восстановительные работы на 36 объектах, реконструирован подъезд к ст. Червленная - Узловая, подъезда от а/д М-29 «Кавказ» к селу Н.Герзель, завершены работы по реконструкции 4-х мостов общей протяженностью 102,22 п.м. [10] В 2021 году в рамках нацпроекта «Безопасные и качественные автомобильные дороги» в Грозном подлежат ремонту 47 улиц общей протяженностью 54,7 км. [9]

Согласно отчетов Министерства транспорта и связи Чеченской Республики, в рамках государственной программы «Развитие транспортной 174 
системы и связи Чеченской Республики» в 2019-2020 годах проведена работа по установке, замене, демонтажу и содержанию технических средств организации дорожного движения (дорожных знаков, разметок, светофоров) на автомобильных дорогах общего пользования»: построено 3 и реконструировано 4 светофора, установлено 264 дорожных знака, проведены ремонтновосстановительные и другие работы 205 объектов, произведена дорожная разметка 476 км дорог, разметка 6945 пешеходных переходов, техническое обслуживание 150 светодиодных светофорных объектов и 1000 дорожных знаков. [3]

В 2019 году в Чеченской Республике, как и в других субъектах федерации, внедрена общедоступная информационная Система контроля за формированием и использованием средств дорожных фондов всех уровней (далее - СКДФ).

Проект нацелен на внесение в СКДФ информации о характеристиках 100\% автомобильных дорог общего пользования Российской Федерации: протяженность; идентификационный номер; площадь покрытия проезжей части; класс; проектная пропускная способность; максимальная скорость по проектной документации; дата ввода в эксплуатацию; балансовая и остаточная стоимость; платность; число полос движения; аварийно-опасные участки и др. На внедрение общероссийской СКДФ из федерального бюджета выделено 250 млн. руб. [6]

Ключевые функции СКДФ: учет данных об автодорогах и их состоянии в цифровом виде; мониторинг программ ремонтных работ и их выполнения; поддержка проектной деятельности в сфере дорожного хозяйства; предоставление данных всем категориям потребителей в удобной форме, пригодной для обработки. По данным Министерства автомобильных дорог Чеченской Республики, проведена валидация и верификация информации о республиканских автомобильных дорогах общего пользования, содержащейся в системе.

По данным РосдорНИИ, в ноябре 2020 года в СКДФ было зарегистрировано более 14 тыс. активных пользователей. Большинство из них - представители организаций-владельцев дорог. [8]

Объемы финансирования и планируемые результаты по национальному проекту «Безопасные и качественные дороги» в Чеченской Республике представлены в таблице 2 . 
Таблица 2

\begin{tabular}{|c|c|c|c|c|c|c|c|}
\hline \multirow[t]{2}{*}{ Наименование результата } & \multirow[b]{2}{*}{\begin{tabular}{|c|} 
Объем \\
финансового \\
обеспечения \\
на 2019- \\
2024г., \\
млн руб
\end{tabular}} & \multicolumn{6}{|c|}{ Значения результата по годам его реализации } \\
\hline & & $\begin{array}{c}\text { План } \\
\text { на } \\
\text { 2019г. }\end{array}$ & $\begin{array}{c}\text { План } \\
\text { на } \\
2020 \text { г. }\end{array}$ & $\begin{array}{c}\text { План } \\
\text { на } \\
2021 \text { г. }\end{array}$ & $\begin{array}{c}\text { План } \\
\text { на } \\
2022 \text {. }\end{array}$ & \begin{tabular}{|c} 
План \\
на \\
2023г.
\end{tabular} & $\begin{array}{c}\text { План } \\
\text { на } \\
2024 \text { г. }\end{array}$ \\
\hline \begin{tabular}{|l} 
Всего по национальному проекту \\
«Безопасные и качественные дороги» в ЧР
\end{tabular} & & & & & & & \\
\hline $\begin{array}{l}\text { На сети автомобильных дорог общего } \\
\text { пользования федерального, регионального или } \\
\text { межмуниципального значения, дорожной сети } \\
\text { городских агломераций выполнить дорожные } \\
\text { работы в целях приведения в нормативное } \\
\text { состояние, снижения уровня перегрузки и } \\
\text { ликвидации мест концентрации дорожно- } \\
\text { транспортных происшествий }\end{array}$ & 2857,67 & 1 & 1 & 1 & 1 & 1 & 1 \\
\hline $\begin{array}{l}\text { Разместить автоматические пункты } \\
\text { весогабаритного контроля транспортных } \\
\text { средств на автомобильных дорогах } \\
\text { регионального или межмуниципального, } \\
\text { местного значения }\end{array}$ & 33,03 & 1 & 1 & 1 & 1 & 1 & 1 \\
\hline $\begin{array}{l}\text { Увеличить количество стационарных камер } \\
\text { фотовидеофиксации нарушений правил } \\
\text { дорожного движения на автомобильных } \\
\text { дорогах регионального или } \\
\text { межмуниципального, местного значения до } \\
211 \% \text { от базового количества } 2017 \text { года }\end{array}$ & 70,35 & 111 & 133 & 150 & 166 & 188 & 211 \\
\hline $\begin{array}{l}\text { Внедрить интеллектуальные транспортные } \\
\text { системы, ориентированные на применение } \\
\text { энергосберегающих технологий освещения } \\
\text { автомобильных дорог }\end{array}$ & 183,20 & & & & & & 1 \\
\hline $\begin{array}{l}\text { Разработать программу комплексного } \\
\text { развития транспортной инфраструктуры. }\end{array}$ & 36,46 & & 1 & & & & \\
\hline
\end{tabular}

Источник: Единый портал бюджетной системы РФ.

http://budget.gov.ru/epbs/faces/p/ Национальные \%20проекты/ Перечень\%20 региональных\% 20проектов

В 2019 году размещен автоматический пункт весогабаритного контроля на автомобильной дороге регионального значения Чеченской Республики Ищерская-Червленная. [9]

На протяжении 2020-2023 годов запланирован мониторинг 43 маршрутов регулярных перевозок пассажиров на предмет наличия в них аварийно-опасных участков и небезопасных маневров. В 2021 году намечено оснастить 
тахографами автомобили 100 транспортных предприятий республики. Совместно с ФАУ «РосдорНИИ» прорабатываются региональные проекты (программы) и определяются для применения новые технологии, материалы и технологические решения. Рассчитываться эффект от применения проектов. Будет организована система наблюдения и контроля за участками внедрения проекта, в том числе, общественный контроль.

В 2021 году проектом намечено приобретение в районные медицинские учреждения хроматографов для выявления состояния опьянения в результате употребления наркотических средств, психотропных или иных вызывающих опьянение веществ.

Также запланировано оснастить медицинские организации автомобилями скорой медицинской помощи класса «С» для оказания скорой медицинской помощи пациентам, пострадавшим при дорожно-транспортных происшествиях. [1] В Чеченской Республике ежегодно утверждаются межведомственные планы мероприятий по освещению в средствах массовой информации вопросов безопасности дорожного движения.

Созданы условия для вовлечения детей и молодежи в деятельность по профилактике дорожно-транспортного травматизма, включая развитие детскоюношеских автошкол, отрядов юных инспекторов движения.

Организована системная работа с родителями по обучению детей основам правил дорожного движения и привитию им навыков безопасного поведения на дорогах, обеспечению безопасности детей при перевозках в транспортных средствах.

Государственными учреждениями Министерства культуры Чеченской Республики совместно с инспекторами ГИБДД в целях повышения грамотности населения, прежде всего, школьников и студентов, в вопросах безопасности дорожного движения регулярно проводится очень большая просветительская работа. В 2018 г. в рамках профилактики ДТП на базе государственных учреждений минкультуры Чеченской Республики проведено 282 мероприятия, в том числе беседы, лекции, показы тематических спектаклей и видеофильмов, экскурсии и совещания, уроки безопасности, круглые столы, инструктажи.

Это беседы и лекции с участием инспектора ГИБДД на темы: «Важность соблюдения ПДД», «Дорожная разметка. Дорожные знаки», «Управление транспортным средством (ТC) водителем, не имеющим права управления ТС», «Правила дорожного движения и профилактика детского дорожно- 
транспортного травматизма», «По дорогам нашего города», «Азбука маленького пешехода», «Дорожная азбука», др. Для детей проводятся спектакли, например, «Дорожные приключения Незнайки и Шапокляк».

В данных мероприятиях, проходивших по всей территории республики, приняли участие 20137 человек. В 2019 году было проведено 313 мероприятий, в ходе которых охвачено 17955 человек.

В 2020 году проведено 166 мероприятий, в ходе которых знания по вопросам безопасности движения получили 5699 человек. В связи с действием ограничительных мер, связанных с проведением мероприятий по профилактике и контролю за распространением коронавирусной инфекции COVID-19 в 2020 году указанные мероприятия проводились в дистанционном режиме. [4]

Активную роль в работе по достижению целей безопасности на дорогах выполняют учебные заведения, религиозные учреждения, государственные учреждения исполнительной власти, некоммерческие организации республики. И даже футболисты. Так, в начале августа 2019 года в центре города Грозный сотрудники ГИБДД при участии футболистов футбольного клуба «Ахмат» организовали профилактическое мероприятие, направленное на предупреждение дорожно-транспортных происшествий, повышение уровня культуры и правовой ответственности водителей транспортных средств. Члены сборной республики по футболу провели беседы с водителями, раздали им флаеры, а также подарили водителям билеты на матч чемпионата России, который состоялся 11 августа на домашней арене.

Удивленные и радостные водители обещали футболистам и инспекторам соблюдать правила законопослушного поведения на дорогах и пользуясь случаем, брали автографы у футболистов. [11]

На 2021 год в рамках национального проекта намечено приобретение технические средства обучения, наглядных учебных и методических материалов для организаций, осуществляющих обучение детей, работу по профилактике детского дорожно-транспортного травматизма. [1]

В республике налажено ежегодное повышение квалификации сотрудников пожарно-спасательных подразделений МЧС России, принимающих участие в ликвидации дорожно-транспортных происшествий за счет проведения совместных учений и соревнований пожарно-спасательных подразделений, подразделений полиции, медицинских учреждений, дорожных служб. 
Реализация намеченных мероприятий национального проекта дает существенные результаты. Согласно республиканской программы «Безопасность дорожного движения», запланировано за период 2018-2024 годы снизить показатель числа погибших в ДТП в 3,5 раза (табл. 3).

Таблица 3

\begin{tabular}{|l|c|c|c|c|c|c|c|c|}
\hline \multirow{2}{*}{ Наименование показателя } & \multicolumn{2}{|c|}{ Базовое значение } & \multicolumn{5}{c|}{ Период, год } \\
\cline { 2 - 8 } & Значение & Дата & 2019 & 2020 & 2021 & 2022 & 2023 & 2024 \\
\hline $\begin{array}{l}\text { Количество погибших в } \\
\text { дорожно-транспортных } \\
\text { происшествия в } \\
\text { Чеченской Республике, } \\
\begin{array}{l}\text { человек на 100 тысяч } \\
\text { населения }\end{array}\end{array}$ & 8 & 01.01 .18 & 7,3 & 6,72 & 6,02 & 5,16 & 3,94 & 2,29 \\
\end{tabular}

http://docs.cntd.ru/document/550330124

Фактически за 2016-2019 годы смертность от транспортных несчастных случаев снизилась в 2 раза (табл. 4). Показатель «Число умерших от всех видов транспортных несчастных случаев на 100000 человек населения» за 2019 год ниже планового показателя.

Таблица 4

Смертность по основным классам причин смерти

в Чеченской Республике (чел.)

\begin{tabular}{|l|l|l|l|l|l|l|l|}
\hline & 2013 & 2014 & 2015 & 2016 & 2017 & 2018 & 2019 \\
\hline $\begin{array}{l}\text { Смертность от всех видов } \\
\text { транспортных несчастных } \\
\text { случаев }\end{array}$ & 103 & 142 & 145 & 176 & 166 & 107 & 86 \\
\hline $\begin{array}{l}\text { Число умерших от всех } \\
\text { видов транспортных } \\
\text { несчастных случаев на } \\
100 \text { 000 человек населения }\end{array}$ & 7,7 & 10,5 & 10,5 & 12,5 & 11,6 & 7,4 & 5,9 \\
\hline
\end{tabular}

Чеченской Республики. Чеченский статистический ежегодник. 2020, С. 44

Дорожно-транспортные происшествия гораздо реже, чем еще пятнадцать лет назад, имеют тяжкий характер (табл. 5). Это связано с рядом факторов: снизилось число аварий по вине пьяных водителей или по причине опасного 
вождения, значительно возросли дисциплина и культура пешеходов и водителей.

Таблица 5

Численность пострадавших в происшествиях с транспортными средствами в Чеченской Республике (человек)

\begin{tabular}{|c|c|c|c|c|c|c|c|c|c|}
\hline \multicolumn{10}{|l|}{ Погибло } \\
\hline & 2005 & 2010 & 2013 & 2014 & 2015 & 2016 & 2017 & 2018 & 2019 \\
\hline $\begin{array}{l}\text { Пострадало в } \\
\text { происшествиях с } \\
\text { подвижным составом: }\end{array}$ & 226 & 212 & 168 & 177 & 166 & 127 & 113 & 94 & 125 \\
\hline $\begin{array}{l}\text { на автомобильных дорогах } \\
\text { и улицах }\end{array}$ & 226 & 212 & 168 & 177 & 166 & 127 & 113 & 94 & 125 \\
\hline $\begin{array}{l}\text { в том числе по вине } \\
\text { водителей транспортных } \\
\text { средств в состоянии } \\
\text { алкогольного опьянения }\end{array}$ & - & - & 2 & 5 & 2 & 11 & 8 & 8 & 11 \\
\hline \multicolumn{10}{|l|}{ Ранено } \\
\hline $\begin{array}{l}\text { Пострадало в } \\
\text { происшествиях с } \\
\text { подвижным составом: }\end{array}$ & 744 & 572 & 745 & 834 & 635 & 585 & 430 & 338 & 373 \\
\hline $\begin{array}{l}\text { на автомобильных дорогах } \\
\text { и улицах }\end{array}$ & 744 & 572 & 745 & 834 & 635 & 585 & 430 & 338 & 373 \\
\hline $\begin{array}{l}\text { в том числе по вине } \\
\text { водителей транспортных } \\
\text { средств в состоянии } \\
\text { алкогольного опьянения }\end{array}$ & - & 24 & 13 & 20 & 19 & 29 & 21 & 17 & 22 \\
\hline
\end{tabular}

Источник: Основные социально-экономические характеристики Чеченской Республики. Чеченский статистический ежегодник. 2020, С. 205

Рост числа происшествий в 2018-2019 годах отчасти связан с улучшением фиксацией нарушений на дорогах за счет оснащения дорог камерами слежения, мобилизацией сил ГИБДД. Инспекторы ГИБДД осуществляют постоянный надзор за дорожным движением, уделяя особое внимание нарушениям, влекущим к тяжким последствиям на дороге - превышение скоростного режима, выезд в нарушение ПДД на встречную полосу движения. Ведется контроль за технической исправностью автомобилей, соблюдением правил перевозки крупногабаритных и тяжеловесных грузов. Выявляются лица, управляющие автомобилями с подложными номерами, нарушающие правила перевозки детей в автомобиле. Проводятся акции по раздаче велосипедистам светоотражающей атрибутики (жилетов, брелоков, наклеек) и другие 180 
мероприятия.В тоже время наблюдается устойчивый рост количества транспорта в Чеченской Республике. За период 2005-2019 годы количество автобусов увеличилось на $65 \%$, количество легковых автомобилей возросло в $3,8$ раза (табл. 6$)$.

Таблица 6

Наличие пассажирских транспортных средств в Чеченской Республике

(на конец года; штук)

\begin{tabular}{|l|c|c|c|c|c|c|c|c|c|}
\hline & 2005 & 2010 & 2013 & 2014 & 2015 & 2016 & 2017 & 2018 & 2019 \\
\hline $\begin{array}{l}\text { Автобусы общего } \\
\text { пользования) }\end{array}$ & 518 & 635 & 527 & 489 & 423 & 845 & 804 & 559 & 854 \\
\hline $\begin{array}{l}\text { Легковые } \\
\text { автомобили }\end{array}$ & 70931 & 136245 & 182151 & 207465 & 224910 & 243148 & 249980 & 258146 & 269315 \\
\hline $\begin{array}{l}\text { в том числе в } \\
\text { собственности } \\
\text { граждан }\end{array}$ & 66028 & 127840 & 172064 & 197645 & 213488 & 231526 & 237900 & 245525 & 255760 \\
\hline
\end{tabular}

Источник: Основные социально-экономические характеристики

Чеченской Республики. Чеченский статистический ежегодник. 2020, С. 190

Следовательно, доля ДТП на одну транспортную единицу значительно снизилась в Чеченской Республике. Чеченская Республика по сравнению с соседними регионами, особенно, Республикой Дагестан и Республикой Ингушетия, приобрела репутацию региона с надежными и безопасными дорогами. Хотя до идеала еще далеко и следует продолжать работу.

Изучив особенности формирующейся транспортной инфраструктуры Чеченской Республики нами был сделан ряд выводов основные из которых следующие:

a) анализ структуры перевозки по видам транспорта в республике показал, что основная часть из них в 2020 году приходится на автомобильный $60,01 \%$, затем на газопроводный $-35,83 \%$, железнодорожный $-3,58 \%$ и воздушный $0,58 \%$ от общих перевозок;

б) анализ протяженности автодорог общего пользования с асфальтобетонным покрытием по районам Чеченской Республики показал, что наибольшая их протяженность наблюдается в Ножай - Юртовский районе 303,8 км. (11,3\%), а наименьшая в Сунженском - 47,9 км. и Шаройском районе - 51,7 км. (1,9\%), по другим районам республики она колеблется от 116,3 км. до 290,9 км;

в) протяженность железных дорог в республике составляет 695 км. Железнодорожный узел Грозненского отделения Северо-Кавказской железной 
дороги расположен на магистрали Грозный - Гудермес - Моздок-Прохладный Ростов (Терский ход);

г) на территории республики функционирует один гражданский аэропорт Грозный «Северный». В настоящее время он в состоянии принимать самолеты среднего класса, пропускная способность аэровокзала - 150 - пассажиров в час;

д) доходы от оказания транспортных услуг в ЧР каждый год стабильно растут и данный вид деятельности в современных условиях рентабелен, за анализируемый период прибыль динамично растет и 2020 год по сравнению с 2010 годов увеличилась на $111,2 \%$;

е) значительная часть сельских населенных пунктов округа не обеспечена круглогодичной связью с опорной транспортной сетью по дорогам с твердым покрытием.

Таким образом, необходимость разработки перспективных направлений развития транспортного комплекса ЧР, в рамках «Стратегии социальноэкономического развития Чеченской Республики до 2025 года» обусловлена следующими причинами:

1. Выходом экономики Чеченской Республики на качественно новый этап своего развития, основанный на макроэкономической стабильности, высоких темпах роста, расширении инвестиционных возможностей, а также переходом от экспортно-сырьевого к инновационному типу развития и социальноориентированной модели развития общества.

2. Процессом интеграции национальной экономики, а следовательно, и транспортной инфраструктуры в мировую, который сопровождается усилением внутриотраслевой и международной конкуренции, растущими требованиями ко всем составляющим транспортного процесса.

3. Завершением в транспортной сфере начального этапа рыночных преобразований, охватившего все подотрасли дорожно-транспортной инфраструктуры.

4. Наличием системных проблем в развитии транспортно-дорожного комплекса Чеченской Республики, необходимостью устранения инфраструктурных ограничений долгосрочного развития экономики республики.

5. Необходимостью учета на региональном уровне приоритетов Российской транспортной стратегии, а также разрабатываемых стратегических документов развития экономики и отраслей транспорта Российской Федерации. 


\section{Список литературы}

1. Бычков В.П. Предпринимательская деятельность на автомобильном транспорте. Перевозки и автосервис. - М.: Академический Проект, Константа, 2019 г.

2. Единый портал бюджетной системы РФ. http://budget.gov.ru/ epbs/faces/p/ Национальные проекты/ Перечень региональных проектов.

3. Национальный проект России «Безопасные и качественные автомобильные дороги». http://government.ru/rugovclassifier/844/events/

4. Результаты деятельности министерства транспорта и связи Чеченской Республики за 2020 год. http://mtischr.ru/images/stories/novosti2020/otchet 30122020.pdf

5. Информация о проведенных мероприятиях Министерством культуры Чеченской Республики в рамках подпрограммы «Повышение безопасности дорожного движения в Чеченской Республике» государственной программы Чеченской Республики «Развитие транспортной системы и связи Чеченской Республики» // https://mk-chr.ru/index.php.

6. Основные социально-экономические характеристики Чеченской Республики. Чеченский статистический ежегодник. 2020, 272 С.

7. Методические рекомендации по реализации мероприятий по внедрению общедоступной информационной системы контроля за формированием и использованием средств дорожных фондов (СКДФ) всех уровней в 2019 году. http://rosdornii.ru/about/natsionalnyy-proekt/Методические\% 20рекомендации \%20по\%20работе\%20в\%20СКДФ.pdf.

8. Паспорт государственной программы Чеченской Республики «Развитие дорожной отрасли Чеченской Республики» на 2019 - 2024 годы. http://docs.cntd.ru/document/553132275.

9. РБК: Как работает новая система контроля за дорожными фондами. https://trends.rbc.ru/trends/industry/cmrm/5fa948e99a7947e8306547a7.

10. План мероприятий по реализации регионального проекта «Общесистемные меры развития дорожного хозяйства Чеченской Республики». https://www.minavtodor-chr.ru/2019/02/25/statisticheskie-dannye.

11. Новости ДТП на дорогах Чеченской Республики // https://helpradar.ru/news /chechenskaya-respublika 
УДК 614.8.084(075.8)

\title{
ОБЕСПЕЧЕНИЕ БЕЗОПАСНОСТИ ТУРИСТИЧЕСКОЙ СФЕРЫ И ЕЁ ЭФФЕКТИВНОСТЬ (КРАТКИЙ ОБЗОР ЛИТЕРАТУРЫ)
}

Прокопьев Виктор Николаевич

Тюменский индустриальный университет

Аннотация: В статье представлены результаты анализа доступной медико-педагогической научно-практической литературы, касающейся вопросов, связанных с предоставлением человеку различных услуг туристической сферы. Рассмотрены исследования, касающиеся становления сферы туризма в нашей стране, вопросы безопасности активного отдыха.

Представлены работы, касающиеся развития спортивного туризма, отдыха на круизных судах, автобусного туризма, делового и научного туризма, астрономического и гастрономического туризма, водного и экологического туризма, горного и велосипедного туризма, охотничего, конного, лыжного и пешего туризма, экстремального и промышленного туризма, а также игорного и винного бизнеса как объектов туризма.

Ключевые слова: современные виды туризма, обеспечение безопасности человека.

\section{ENSURING THE SAFETY OF THE TOURISM INDUSTRY AND ITS EFFECTIVENESS (BRIEF LITERATURE REVIEW)}

\section{Viktor Prokopiev}

\begin{abstract}
The article presents the results of the analysis of accessible medical and educational scientific and practical literature concerning issues related to the provision of various services of the tourism sector to the person. Research on the development of tourism in our country and the safety of outdoor activities are considered. Works related to the development of sports tourism, cruise ship recreation, bus tourism, business and scientific tourism, astronomical and gastronomic tourism, water and environmental tourism, mountain and cycling
\end{abstract}


tourism, hunting, equestrian, ski and foot tourism, extreme and industrial tourism, as well as gambling and wine businesses as tourism facilities are presented.

Key words: modern types of tourism, ensuring human security.

Актуальность. Анализ научно-практической литературы, касающейся туризма, свидетельствует, что туристический сектор является сложной системой, который во многом зависит от ряда причин и условий и, в частности, от человеческого фактора, при этом туристическая отрасль является одной из уязвимых сфер в плане обеспечения безопасности, в том числе и антитеррористической. На сегодняшний день активный туризм является одним из наиболее стабильно динамично развивающихся сегментов туристского бизнеса, становясь при этом важным фактором социального и экономического развития территории и, при этом, сохраняя природные ландшафты и ресурсы. Основными видами индивидуального и коллективного активного туризма являются: пешеходный, велосипедный, водный, лыжный, горный и др. Активные виды туризма в значительной степени зависят от времени года, поэтому их можно разделить на две большие группы: летние и зимние [Винокурова М.С., Орлова К.А., Видина О.А., 2010; Ковалева О.В. с соавт., 2019; Тортумашева Я.В., 2020].

Так, для проведения летних видов активного туризма и отдыха необходим комфортный период, который возможен при сочетании следующих метеорологических факторов: скорости ветра от 0 до 6 м/с, температуре воздуха от 12 до $30^{0} \mathrm{C}$, относительной влажности воздуха от 30 до $70 \%$, интенсивности солнечной радиации от 0 до 838 Дж/см². Ветер, скорость которого превышает 6 м/с для человеческого организма является физиологически вредным. При указанном сочетании метеорологических факторов терморегуляторная нагрузка организма является минимальной, наступает комфортное состояние организма, или т. н. физиологический оптимум [Бузякова И.В., 2019; Клюева М.В. с соавт., 2020].

Несмотря на многоплановые научные исследования, касающиеся сферы туристического бизнеса, многие вопросы, касающиеся обеспечения безопасности туристов, остаются не решенными.

Цель: на основании изучения современной научно-практической литературы, касающейся туризма, дать оценку состояния безопасности человека в туристической сфере. 
Материал и методы. Проведен анализ 355 медицинских, юридических и педагогических научно-практических работ, характеризующих обеспечение безопасности человека в различных разделах туристической сферы. Методами исследования выступили теоретический анализ литературных источников и Интернет-ресурсов.

Результаты и обсуждение. Известно, что туризм играет огромную роль в формировании бюджета России и многих стран мира [Кухарская Е.Ю., 2018; Моисеенко Д.Д., 2017]. Роль туризма, способствующего развитию экономического, политического, культурного сотрудничества, снижению уровня безработицы, повышению занятости населения и т.д., неуклонно растет [Атаев А.Г., 2011; Быкова Е.А., Фомин И.В., 2018; Зиганшин И.И., Овчаров А.О., Рысаева М.А., 2015; Кочкаров З.Ж., 2017; Кучина О.В., Кучина М.Д., 2015; Мачалкин С.Е. с соавт., 2019; Потапова К.К., 2016; Фирсов А.И. с соавт., 2017].

Являясь важной статьей экспорта услуг, туризм создает необходимые предпосылки для вовлечения регионов страны и различных государств мира в систему международного разделения труда. Можно утверждать, что именно туризм является наиболее перспективным инструментом диверсификации хозяйственной деятельности нашей страны [Борисова И.С., 2015; Валитова Т.А., 2016; Гришина И.В., Котов А.В., 2018; Жукова Ю.С., 2018].

Туризм способен оказать максимальное содействие по выводу депрессивных территорий на необходимый вектор социально-экономического развития [Кошанов А.К., Багаева Н.У., 2018; Макринова Е.И., Лысенко В.В., 2017; Норкулова Д.3., Бойназаров У.Э., 2018; Сиднева С.И., Асташина Н.И., 2020].

Туризм является одним из основных факторов, который позволяет получать конкурентные преимущества фирмам, регионам и даже многим странам. Фактом является то, что туризм может быть источником развития только при условии активного и в значительной степени эффективного использования современных теорий, а также создания благоприятной среды для их инициирования [Латорцев А.А., Белоусова Ю.С., 2018; Морозов М.А., 2013].

Для многих стран мира, в том числе и нашей страны, туристическая отрасль является источником поступления финансовых средств [Демачева К.В., Кострюкова О.Н., 2016; Латушко Н.А., Гнездилова В.В., Рубан Д.А., 2016; Понедельник А.А., Рубан Д.А., 2016; Понедельник А.А., Соковнина Н.В., Рубан 
Д.А., 2017; Яшалова Н.Н. с соавт., 2018; Baldigara Т., Mamula M., 2015; Deng T., Ma M., Shao S., 2014; Dogru T., Sirakaya-Turk E., Crouch G.I., 2017; Cro S., Martins A.M., 2017; Peng B., Song H., Crouch G.I., 2014; Iastremska O., 2014].

Так, например, доход России от туризма в 2017 г. вырос до 3 трлн руб., что составляет около $3,47 \%$ ВВП. В качестве доказательства приведу в пример столицу России г. Москву, которую только за один год посетило 26 млн человек и они потратили на всё про всё 860 млрд руб.

Следует признать, что туристическая отрасль в нашей стране развита слабо, а туристический сервис по конкурентоспособности во многих регионах России значительно уступает сервису других стран [Андрианов В. И., 2015; Голованова Д.А., 2020; Мачалкин С.Е., Морева С.Н., 2018; Харитонова Т.В., Вапнярская О.И., Голикова О.М., 2014; Цветкова Н.А., 2016]. Финансовые доходы России от туризма на сегодняшний день не велики [Бобровский Е.А., 2020; Лапинова С.А., Липатов Д.О., 2017; Фиклисова О.А., 2012; Яшалова Н.Н. с соавт., 2018].

Туризм оказывает стимулирующее влияние на транспортную инфраструктуру, торговлю, экономику, является серьезным стимулом создания новых рабочих мест, снижает безработицу, тем самым повышая налогооблагаемую базу [Абдурахманова Л.Р., 2019; Ёров Дж.Н., 2016; Кузнецова Е.И., 2020; Леонидова Е.Г., 2017; Пьянкова С.Г. с соавт., 2019; Федорова Е.А., 2020].

Вопросы безопасности сферы туризма широко и всесторонне изучаются в сфере юристпруденции, физической культуры и спорта, маркетинга [Акопян А.Д., Саенко И.И., 2019; Возисова М.А., Шутова Т.Н., 2016, 2017; Возисова М.А., 2017; Возисова М.А. с соавт., 2018; Волков С.К., 2018; Волчек Д.Д., Пузыревская А.А., 2020; Колодник Т.Д., 2020].

К вопросам безопасности и защиты человека в туризме необходимо подходить и рассматривать их с разных точек зрения [Махов С.Ю., 2014]. Всемирная организация по туризму - The World Tourism Organization решает эти вопросы в рамках качества торговли и ее стандартов. Она дает определение безопасности и защите как первостепенным основополагающим факторам, способствующим качеству в туризме и предоставлении туристического продукта [Кобец П.Н., 2020].

Изучение проблемы безопасности туристов важно в условиях стабилизации туристской отрасли [Бойназаров У.Э, 2019; Бырдин В.С., 
Цеханович О.М., 2013; Иванцова Т.М., 2014; Кочетков Н.М., 2006; 2007; Манько Н.П., Староверкина Н.Н., 2013; Ремпель О.В., 2014; Темирчиева Д.Ф., 2019; Шишкин В.В., 2018].

Следует учитывать, что задача развития туризма требует решения множества других сопутствующих задач, таких как развитие транспортной системы, развитие системы общественного питания, развитие информационной инфраструктуры, улучшение имиджа [Сенин В.С., 2008].

В последние годы туристические потоки различных контингентов населения, как в мире, так и в нашей стране увеличились в несколько раз, особенно в крупные города и округах [Кузнецов Л., 2011; Кульгачев И.П. с соавт., 2020; Левченко Г.Н., Зайцев О.С., Гарцев А.В., 2020; Логвина Е.В., 2018; Лощинина А.М., Решетникова Е.О., 2016; Сафронова П.А., 2020].

В нашей стране различные виды туризма развивается в различных регионах [Ильина С.А., Демочкина Т.Н., Донцов В.В., 2016; Махова Н.С., 2016, 2017; Махов С.Ю., 2019]. Кратко остановимся на наиболее массовых востребованных видах туризма.

Спортивный туризм в настоящее время является эффективным средством в борьбе с растущей гиподинамией современного общества. Спортивный туризм широко культивируется на территории нашей страны и занимает значительное место среди многих средств воспитания детей, подростков и молодежи, обеспечивает комплексное воздействие на всестороннее развитие человека, служит проявлением здорового образа жизни [Булашев А.Я., 2007; Бутенко Т.В. с соавт., 2019; Гуляев П.Д., Тарасов А.Е., 2018; Коновалова Е.Е., Седов С.Ю., 2018; Кораблев В.А., 2019; Мулик Е.В., Мулик В.В., 2015; Рубис Л.Г., 2013; Федотов Ю. Н., 2008; Чекмарева Н. с соавт., 2019].

Набирает популярность отдых на круизных судах [Байков А.В., 2013; Басюков Г.Т., 2018; Бердник К.М., Рассказова Е.Е., 2020; Деньщик А.С., Алексеева О.А., 2018; Корсун Е.А., Фокин Д.Н., 2017; Логунова Н.А., 2013; Мацарин А.С., 2019].

Продолжают развиваться и совершенствоваться автобусный туризм. На сегодняшний день автобусные туры - самый демократичный и общедоступный способ путешествия. Автобусный туризм становится все более перспективным направлением российского туристического бизнеса [Бекешев А.Ю., 2018; Голомолзин Е., 2013; Муртазина Г.Р., 2014; Осипова О.Я., 2007; Поспелова 
С.В., 2018; Симакова Е.И., 2020; Соловьянова М.В., Сиделева Ю.Д., 2019; Тихонова Н.В., Скороходова А.Э., 2018; Фурзикова М.А., Петухова М.Г., 2020; Цветков Е.И., 2015; Чэнь Сю., 2017].

За последние годы в России интенсивно и динамично развивается деловой туризм [Алексеева Ю.П., Ибрагимова В.М., Галимов Ш.Ш., 2020; Борисова А.В., 2015; Дегтярёва Т.В., Борисенко И.В., 2018; Демачева К.В., Карпова Е.Г., 2017; Карманова А.Е., Курочкина А.А., 2019; Кошин И.И., Кошина О.В., 2020; Тургинбаева А.Н., Жакупбекова Г.Е., 2020].

Научный туризм как одно из самостоятельных направлений отечественного туризма возник в 80-х годах прошлого века по инициативе Географического общества Академии Наук СССР (в настоящее время Русское Географическое общество) [Голубев С.В., 2016].

В последнее время «научный туризм» предлагается относить к одной из форм научной дипломатии. Реализация научного туризма будет способствовать, с одной стороны, не только увеличению числа международных контактов учреждений науки и образования нашей страны путём организации ознакомительных и рекламных поездок для широкого круга представителей зарубежных научных, образовательных и иных организаций с целью ознакомления с научной деятельностью России. С другой стороны, это будет способствовать росту туризма в целом [Васильев А.В., Пивоваров А.Н., 2016; Крылова Е.А., 2018; Любарская М.А., Любарский А.Н., 2013; Мельникова Е.Е., 2017; Эрбен А.С., Анисимова В.В., 2019].

Астрономический туризм. Данный вид туризма является одним из молодых направлений туризма, которое стало развиваться в Российской Федерации недавно, но, тем не менее, с каждым годом приобретает все большую популярность [Имамаев Ш.Н., 2019; Пиоль М., 2016; Ползикова М.А., Кутепова Г.Н., 2019; Шмырев Д.А., 2019].

Как известно, гастрономический туризм - вид туризма, основной целью которого является знакомство широких масс населения с кухней той или иной страны [Балынин К.А., 2017; Курбанова А.М., 2020; Мартьянова Е.Г., Чеснова Е.Н., 2019; Пономарева М.В., Комкова А.А., 2017]. Мы рассматриваем гастрономический туризм, как современное перспективное направление развития туризма.

Следует иметь в виду, что на западе деловой туризм существует с 1841 года, в то время как в России он появился только в 1990-х годах. Сектор 
делового туризма активно развивается в 150 странах, и крупные бизнес мероприятия проходят, чаще всего, не в столицах, а в регионах [Маклашина Л.Р., 2011]. По прогнозам совокупный годовой рост расходов на деловой туризм в Бразилии, России, Индии и Китае будет идти в два-три раза быстрее, чем в развитых странах, таких как США, Франция, Германии и Великобритания. В настоящее время на индустрию делового туризма приходится $60 \%$ всего мирового туризма, 55-60\% мест в отелях заполняется за счет деловых поездок.

Особой популярностью в стране пользуется водный туризм [Козырева М.С., 2019; Колобова А.Е., Матвеев С.С., 2020; Литвинов А.Е., 2011; Маклашина Л.Р., 2011; Орлова В.С., 2016; Пштыка В.В., 2009; Решняк В.И. с соавт, 2019; Соловьев Михаил Максимович с соавт., 2020; Старкова И.И., Крыласова Е.А., Доржиева Л.Г., 2020; Суданова С., 2015; Фафикова А.Е., 2016; Хасянова А.Р., 2015].

Отрадно отметить, что в последние годы динамично развивается экологический туризм [Васильева А.А., Матвеева А.А., 2017; Задевалова С.В., Бутова Т.Г., Задевалов В.И., 2013; Закамская Л.Л., Секлецова О.В., Кузнецова О.С., 2012; Романчук О.Н., Суворов А.П., 2015; Куприна Л.Е., 2015; Лапшина А. Е., 2008; Овсянникова С.А., 2015; Сергеева Т.Л., 2004; Тесленко В.В., Романова Е.В., 2019; Тимерханова Э.И., 2020].

Туризм - одна из востребованных и развивающихся отраслей, поскольку все большее количество людей стремится разнообразить свой отдых. Однако, как результат той или иной деятельности человека, туризм оказывает и негативное влияние на земельные, энергетические, водные ресурсы, тем самым усугубляется и без того непростую экологическую ситуацию. В этой связи всё большую популярность приобретает экологический туризм - единственное направление в индустрии туризма, позволяющего сохранить природную среду. Экотуризм - это не только разновидность природного туризма, объединяющего людей, которые путешествуют с научно-познавательными целями, сферой интересов которых являются не только окружающая природная и культурная среда, но еще и возможность быть активным защитником этой среды [Сергеева Т.Л., 2004].

Парусный туризм можно назвать разновидностью экологического туризма [Барабанова М.И., Чикова И.И., 2018; Баранов С.Д., 2016; Волостных В.В., 2017; Григорьева Д.К., 2016; Жуков П.В., 2018; Иванова Е.В., 2012; Томилин К.Г., 2015, 2016; Черняк А.Ю., 2018]. 
Все большую популярность в различных регионах нашей страны приобретает велосипедный туризм [Алексеев-Стасов П.М., Колодезникова С.И., 2019; Бахсыров Ю.Ю., Лисагор М.В., 2016; Гужова Л.Г., Наймушина А.А., 2020; Кожемяк Е.Ю., 2017; Куклев В.А., Евграфов И.Е., 2018; Микитюк К.В., 2019; Ожева С.Б., Суетина Н.М., 2017; Юдина Е.Ю., 2017; Яцык В.З., Букреева Н.О., Предко Ю.Ю., 2020].

Следует отметить всё возрастающий интерес населения нашей страны, как к горному туризму [Алибеков Ш.И., Исмаилова М.А., 2018; Газмагамаев M.М., 2020; Имангулова Т.В., Нусупова Л.С., 2018; Имангулова Т.В., Нусупова Л.С., Закирьянов Б.К., 2018; Каракетов А.К., 2019; Мирошниченко П.Н., 2019; Селиванов В.В., 2019; Успенский А.А., Савкина Н.В., 2019;], так и альпинизму как виду туризма [Бобылев В.Ю., 2015; Галачиева Л. А., 2012; Нерукова М.В., 2017].

На протяжении многих десятилетий для человека привлекательным является охотничий туризм [Абросимова И.В., 2020; Алексеева Н.Д., 2012; Арутюнян С.А., 2013; Балашов А.Н., 2019; Воинова Н.Е., Нелепина Е.А., 2015; Ковальчук А.Н., 2020; Мельников В.В., Мельников В.К., Кентбаев Е.Ж., 2014; Монахова Г.Н., 2019; Мякишева С.Н. с соавт., 2014; Турдумамбетов Б.У., 2019; Шоричева А.Ю., 2013, 2014].

С каждым годом всё привлекательнее для различных контингентов населения является конный туризм [Дегтярёва Т.В., 2016; Дегтярёва Т.В., Пасечникова А.А., 2018; Жохова В.В., Соловьева Е.Н., 2013; Исакаева А.П., Утегенов Р.А., Безуглова М.С., 2016; Селиванова А.В., 2019].

Длительная зима во многих регионах нашей страны делает привлекательным лыжный туризм [Арцис Е., 1972; Берман А.Е., 1968; Булашев А.Я., 2014; Водневская Г.В., 2016; Губаненков С.М., 2014; Каюмова Р.Ф., Пичужкина Т.Д., 2017; Ожигов Ю.С., Старкова И.И., 2018; Попов А.Д., 2019; Курилова В.И. с соавт., 2020; Циперсон Э.Х., 2014].

Среди многообразия видов туризма, наиболее привлекательным, относительно мало затратным, познавательным и интересным является пеший туризм [Анисимова Е.Ю., Канцерова И.Е., 2019; Курилова В.И. с соавт., 2020; Маслак Д.В., 2017; Николаева О.К., Тарасов А.Е., 2015; Таскаев Н.А., 2016; Федорко П.Д., Сухорукова И.А., 2020; Щербакова Н.В., Богданова Н.П., 2018], в котором могут принять участие даже неподготовленные люди и дети.

Одними из наиболее востребованных видов отдыха, особенно среди мужчин, на сегодняшний день являются рыболовный и охотничий туризм 191 
[Вагабов М.М., 2016; Ворожко Ю.В., Любина Е.С., 2011; Галимова А.Ф., 2018; Оришев А.Б., 2019; Поколодная М.Н., 2016; Пробин П.С., 2014; Срибная Т.А., Боднева Н.А., 2020; Ткаченко Д.А., 2018; Хлевная Т.И., Назарова Л.Х., 2020; Школьная Л.И., Зуенко В.А., 2020]. Популярность данных направлений обусловлена массовым характером увлечений в нашей стране. Важно также отметить и востребованность по этим направлениям в туризме у лиц зрелого возраста с достаточно высоким уровнем дохода. В связи с введенными в отношении России экономическими санкциями наблюдается значительный отток российских туристов и стран западной Европы [Абакумов С.Н., 2015].

Данное обстоятельство целесообразно использовать для развития рыболовного и охотничьего туризма на территории нашей страны, посредством совершенствования туристской инфраструктуры, повышения качества обслуживания в сфере размещения и питания.

С чувством глубокой гордости следует признать, что многие районы России обладают прекрасными возможностями для развития туризма и создания современной индустрии гостеприимства, которые являются сегодня не только крупнейшими отраслями экономики, но и мощными генераторами рабочих мест [Байбулдина А. А., 2013]. В связи с этим, как в нашей стране, так и многих странах мира, всё большее распространение, особенно среди молодёжи, имеет экстремальный туризм [Акимова М.А., Рубан Д.А., 2016; Алиакберова Э.Р., Волхонская Г.П., 2016; Галачиева Л.А., Шагин С.И., 2015; Луценко Я.А., Романова А.А., 2016; Бакулева В.С., Кутышева А.В., 2017; Гёзалян С.К., Феоктистов С.В., 2015; Домничева А.А., 2017; Ерланкызы А., 2020; Калоева 3.Ю., Туаева К.М., 2020; Каримов А.А., Подлиняев О.Л., 2019; Коппель Д.С., Анисимов Т.Ю., 2015; Сенин В. С., 2008; Шеманаев В.К., 2008; Шепель А.А., 2016].

Всё более значимое место в последние годы приобретает отечественный промышленный туризм [Ангелина И.А., Антонец В.Г., 2016; Белентьева Т.Н., Нарута Я.С., 2015; Волков С.А. с соавт., 2019; Гарнов А.П., Краснобаева О.В., 2012; Гладилин А.В. с соавт., 2018; Головач Э.П., Хутова Е.Н., 2018; Кадыров Р.В., Мударисов Р.Г., 2018; Каночкина Н.А., Попова Д.Д., 2020; Клейменова Е.О., Чулакова А.О., 2014; Костиков А.К., Лихачёв Е.Н., 2020; Плещенко В.И., 2020; Кривцова Е.В., Леутина А.В., Рассохина И.Ю., 2018; Михин А.Э., 2020; Добрейцина Л.Е., 2020; Припотень В.Ю., Шиков Н.Н., 2017; Рыцев А.И., 2014; Струзберг Г.В., 2013; Филипова В.Н., 2011; Ярембаш А.И. с соавт., 2018]. 
Рассматривая виды туризма, нельзя обойти вниманием винный туризм. С определенной долей уверенности винный туризм можно отнести к особому виду туризма, отдыха и путешествий, который набирает все большую популярность среди жителей нашей страны [Басюк Д.И., 2014; Бондаренко С.А., 2016; Канонистова 3.С., 2002; Кусмаков С.Ю., 2019; Маслов Е.С., 2007, 2018; Русанов И.В., 2008; Сухолитко А.С., Абрамова Л.С., 2018; Пергат А.П., 2013; Халапурдина В.В., 2018; Шольц-Куликов Е.П., 2011$].$

Формирование винного туризма ведет своё начало с курортов Черноморского побережья и Краснодарского края. Винный туризм в полной мере соответствуют социально-гуманитарной миссии туристской деятельности как фактору «диалога культур», уважению к общечеловеческим культурным ценностям, образу жизни и традициям, выступая неотъемлемой частью культурного наследия каждой нации. На наш взгляд, винный туризм выполняет две важнейшие функции. Экономические функции винного туризма проявляются в создании дополнительных рабочих мест и повышении занятости населения; формировании доходов туристских предприятий и предприятий виноградарско-винодельческого комплекса. Экологическая функция туризма направлена на сохранение и защиту окружающей среды.

При советской власти игорный бизнес как объект туризма находился под запретом. За последние 30 лет в экономике России произошло реформирование, при котором игорный бизнес в связи с налогообложением в соответствии с гл. 29 Налогового кодекса РФ стал легальным. При этом была определена необходимость развития не только игорных заведений, но и инфраструктуры территорий, включая индустрию «азартного туризма». Следует отметить, что игорному бизнесу в нашей стране посвящено ряд оригинальных научнопрактических исследований [Борисов А.Н., 2004; Вахрушев И.Б., Заславский Г.А., 2018; Калужникова Е.А., Николаева Е.Ю., 2015; Ковтун Е.В., 2004, 2005; Коник Н.В., Яскевич Н.Н., 2008; Семенихин В.В., 2005; Федорченко Н.И., Рябых С.Н., 2014].

В числе факторов, способствующих развитию туризма, приоритетное значение имеют растущая глобализация, быстро развивающаяся транспортная инфраструктура, рост безопасности туриндустрии и др. Современная фаза стратегий и планирований в туриндустрии связана с повышенным интересом к проблемам надежности и безопасности развития отрасли [Кобец П.Н., 2020]. В этой связи вопросы обеспечения безопасности в сфере туризма в настоящее время остаются актуальными [Махова Н.С., 2016.]. 
Обеспечение безопасности туристической индустрии - одна из важнейших составляющих ее эффективного развития [Кобец П.Н., 2020].

Для надлежащей реализации права на отдых вне места проживания физического лица законодатель предусматривает разносторонний комплекс мер, объединенных одной общей целью - обеспечить безопасность туриста [Ефимов О.В., 2013; Кобец П.Н., 2018, 2019], а также его имущественных интересов [Ефимова О.В., 2013; Игбаев Г.Р., 2006].

Решаются вопросы функционирования и расширения сферы влияния туристической полиции, призванной осуществлять безопасность и отдых туристов [Кобец П.Н., 2017; Митюнова И.Г., 2018].

На сегодняшний день туристической полицией располагают многие страны мира, тогда как в нашей стране она находится в стадии формирования [Воробьева Д.Е., Дегтева Е.В., 2019; Заброда Д.Г., Гурченко А.В., 2017; Захарова Е.П., 2015; Иванов А.А., Эриашвили Н.Д., 2018; Иванько И.В., 2018; Кобец П.Н., 2019].

Результаты маркетинговых исследований свидетельствуют о том, что лучшая организация деятельности правоохранительных органов по работе с туристами среди европейских стран осуществятся в Ирландии, а среди азиатских - в Малайзии [Митюнова И. Г., 2018].

С целью обеспечения безопасности туристов в настоящий момент во многих государствах, таких, как Россия, Бангладеш, Греция, Египет, Израиль, Испания, Китай, Латвия, Малайзия, Непал, Южная Корея, Таиланд, Турция и др. функционирует туристическая полиция [Бобкова А.Г., Кудреватых С.А., Писаревский Е.Л., 2014; Воробьева Д.Е., Дегтева Е.В., 2019; Заброда Д.Г., 2018; Иванов А.А., Эриашвили Н.Д., 2018; Митюнова И.Г., 2018; Монтилья Л.В., 2018; Писаревский Е. А., 2010; Темирчиева Д.Ф., 2019]. Еще 30 лет назад было отмечено, что туризм признан крупнейшим генератором преступности [Edgell, D.L., 1990].

Большим событием в истории туризма является то, что 10-14 апреля 1989 года была принята Гаагская декларация межпарламентской конференции по туризму (вместе с «Конкретными выводами и рекомендациями»), в которой было сказано, что: «Безопасность, защита туристов и уважение их достоинства являются непременным условием развития туризма».

Несколько позднее в Сеуле и Осаке 27 сент. 2001 г. на XIV сессии Генеральной ассамблеи Всемирной туристской организации была принята 
Сеульская декларация «Мир и туризм» [URL: http://www.unwto.org], в которой указывается, что «...преднамеренное и умышленное разрушение туристических объектов, хищения объектов культурно-исторического наследия должны преследоваться в соответствии с национальным законодательством каждой страны».

Так, в частности, при поездке за рубеж в страны, являющиеся неблагополучными по особо опасным заболеваниям, туристам предоставляются памятки, а также препараты против малярии [Ефремов А.В., Хрущева Л.Б., 2017; Темирчиева Д.Ф., 2019].

Поскольку мониторинг различных отечественных и зарубежных научных изданий и СМИ, свидетельствует о том, что интерес к деятельности туристической полиции с каждым годом только возрастает. И данный феномен имеет под собой реальные основания, поскольку в условиях начала XXI столетия в силу ряда объективных обстоятельств динамичное формирование и эволюционирование туристической отрасли во многих государствах мира становится невозможным без обеспечения комфорта и безопасности зарубежных туристов в период их пребывания на территории иностранных государств. Во многом это связано с тем, что туристический комплекс продолжает оставаться одним из крупнейших генераторов преступной активности [Кобец П.Н., 2020].

Что касается рейтинга нашей страны по безопасности туризма в России, то французский сайт-агрегатор страхования Россию в рейтинге безопасности для туристов поставил на 86 место [URL: https://www.tourismsafety.ru]. В этом же списке есть и другие страны СНГ: Беларусь (48 место), Азербайджан (52 место), Туркменистан (60 место), Молдова (66 место), Грузия (68 место), Казахстан (71 место), Армения (72 место), Украина (83 место), Таджикистан (93 место) и Кыргызстан (106 место).

Следует отметить положительное влияние, которое внесло Постановление Правительства Российской Федерации от 15 апреля 2014 г. № 317 «Об утверждении государственной программы Российской Федерации «Развитие культуры и туризма» на 2013-2020 годы». Заслуживает особого упоминания то, что Правительство РФ постоянно заботится о развитии туризма в стране. Доказательством являются Постановление Правительства РФ от 02.08.2011 г. № 644 «О федеральной целевой программе «Развитие внутреннего и въездного туризма в Российской Федерации (2011-2018 годы)» и 
Распоряжение Правительства РФ от 31.05 .2014 г. № 941-p (ред. от 26.10.2016 г.) «Об утверждении Стратегии развития туризма в Российской Федерации на период до 2020 года».

Каждая страна, регион, город или место потенциального паломничества туристов должны изучать аспекты безопасности и защиты, непосредственно связанные с потребностями приезжающих к ним. В туризме их необходимо рассматривать с точки зрения путешествующих или тех, кто организует и составляет пакет путешествий (туров) для отдельных лиц или корпоративных клиентов [Александрова А.Ю., 2011; Кобец П.Н., 2017; Максименко С.В., 2001].

В этой связи в нашей стране на протяжении ряда лет проводятся исследования, направленные на принятие законодательных и правовых мер в сфере туризма [Братановский С.Н., 2015; Волошин Н.И., 2007; Кудреватых С.А., Кудреватых А.С., 2015]. Разрабатывается Национальная система законодательства в области регулирования организованного туризма [Егоров В.Е., 2011], в том числе международного [Кобец П.Н., 2020].

Рассматриваются вопросы взаимодействия нашей страны с региональными интеграционными объединениями по вопросам правового регулирования отношений в сфере туризма [Стригулина А.В., 2007].

Вносятся предложения Федерального агентства по туризму к Концепции проекта Федерального закона «О туризме и туристской деятельности в Российской Федерации» [Писаревский Е.Л.].

Издаются работы как монографического плана, отражающие историю развития туризма в России и административно-правовые аспекты безопасного туризма [Биржаков М.Б., Казаков Н.П., 2007; Писаревский Е.Л., 2011; Усыскин Г., 2000; Чудновский А.Д., Жукова М.А., Сенин В.С., 2004], так и диссертационные исследования, регламентирующие условия договора при оказании туристических услуг [Свиридов К.С., 2003; Сирик Н.В., 2001], гражданско-правовое и правовое регулирование туристской деятельности [Барабанова П.С., 2017; Ганн Н.А., 2008; Жмулина Д.А., 2009; Чененов Ю.А., 2003].

Под редакцией Е.Л. Писаревского в 2014 году был издан учебник «Безопасность туризма» [Бобкова А.Г., Кудреватых С.А., Писаревский Е.Л.].

Важное внимание уделяется исследованиям сотрудничества государств по правовому регулированию международной туристской деятельности 
[Братановский С.Н., 2015; Стригунова Д.П., 2009; Чеботарева И.А., 2004] и государственному управлению туризмом [Калинина Л.Е., 2007].

Вопросам гостеприимства и организации индустрии в сфере туризма посвящены различные учебные пособия [Лысенко В.В., 2014; Макринова Е.И., 2012, 2014, 2016].

Не обойдено вниманием специалистов изучение вопросов страхования персональных рисков и возмещения вреда в сфере туризма [Атаев М.Д., 2016; Босси Е.А., 2017; Бобков М.А., 2011; Бурыкин А.А., Спиридонова В.С., 2008; Гулян С.С., Джинджолия Л.Г., 2020; Дубровин Н., 2009; Завьялова С.В., 2014; Науменко Б.В., 2019; Сирик Н.В., Кусков А.С., 2019; Толкачева О.П., Джобинашвили К.А., 2011].

Следует отметить, что в последнее десятилетие правовое регулирование туристской деятельности в России характеризуется положительными тенденциями в реформировании туристского законодательства, однако многие существующие в сфере проблемы не позволяют обеспечить должного уровня защиты прав и законных интересов российских туристов как потребителей туристских услуг [Васецкий В.Н., 2011].

Занятия туризмом влияют на овладение жизненно необходимых человеку умений и навыков, совершенствование его двигательных способностей, развитие моральных, волевых и интеллектуальных качеств. Показано, что занятия туризмом являются мощным средством оздоровления человека [Букреева К.С., Двойникова Е.С., 2018; Губа В.П., Сахарова О.А., 2007; Гусейнов Р.Г, Омаров О.М., 2020; Гуськов В.М., Дрожжаков А.И., 2016; Жегалина Г.В., Жегалина Э.В., 2018; Пугиев В.Г., 2011; Скибина В.А., Демьянова Л.М., Дьяконова Н.А.; 2020; Черкасов В.В., Тартаимова К.А., 2015].

Требования к организации безопасного ведения туристской деятельности всех видов можно подразделить на [Абаев А.В. с соавт., 2018; Абаев В.А., Пальтиель Л.Р., Кизиляева Е.Ю., 2020; Ильяшенко И.Е., Смирнов Д.В., 2019; Федотов Ю.Н., Востоков Е.И., 2004]:

1. организационные требования;

2. требования к технической оснащенности (снаряжению, оборудованию, экипировке и т.д.);

3. требования к состоянию здоровья и к уровню подготовленности участников (медицинским показаниям, физической, психологической, тактической, технической подготовке и др.); 
4. требования к страхованию туристов на случай внезапного заболевания и от несчастных случаев, к страхованию средств передвижения и других технических средств;

5. требования по спасению туристических групп;

6. требования по обеспечению реабилитационных мероприятий (доставка потерпевшего в медицинское учреждение, организация похорон, оказание помощи семье погибшего и т.д.);

7. требования к выполнению профилактических мероприятий.

Таким образом, проведя краткий анализ современной педагогической, медицинской и юридической литературы, посвященной различным вопросам сферы туристического бизнеса в нашей стране, отметим, что туристический бизнес неуклонно и динамично развивается.

\section{Список литературы}

1. Абаев В.А. К вопросу об обеспечении безопасности на туристских маршрутах / В.А. Абаев, Л.Р. Пальтиель, Е.Ю. Кизиляева // Инновационные формы развития, воспитания и культуры студентов: Материалы $\mathrm{X}$ международной научно-практической конференции. - Санкт-Петербург, 14-16 апреля 2020 года. - С. 278-283.

2. Абакумов С.Н. Проблемы интеграции российского туризма в мировую экономику на фоне экономических санкций / С.Н. Абакумов //Вестник Орловского государственного университета. Серия: Новые гуманитарные исследования. 2015. - № 4 (45). - С. 90-94.

3. Абакумов С.Н. Экономический эффект международного туризма в РФ на основе статистических данных Всемирной туристской организации / С.Н. Абакумов //Ученые записки Орловского государственного университета, Орел: ОГУ, 2015. - № 2(65). - С. 38-41.

4. Абдурахманова Л.Р. Влияние транспортной инфраструктуры на развитие туризма в России / Л.Р. Абдурахманова //Сила систем. 2019.№ 1 (10). - С. 17-20.

5. Абросимова И.В. Охотничьи ресурсы Курганской области как фактор развития туризма / И.В. Абросимова // Зыряновские чтения: Материалы Всероссийской научной конференции. - Курган, 03-04 декабря 2020 года. C. $183-184$.

6. Акимова М.А. Экстремальный туризм: совершенствование классификации / М.А. Акимова, Д.А. Рубан //Географический вестник. 2016. № 1. - C. 95-103. 
7. Акопян А.Д. Туристический маркетинг / А.Д. Акопян, И.И. Саенко // Colloquium-journal. 2019. - № 13-9 (37). - С. 31-32.

8. Акопян А.Д. Туристический маркетинг / А.Д. Акопян, И.И. Саенко // Colloquium-journal. 2019. - № 14-5 (38). - C. 32-33.

9. Александрова А.Ю. Международный туризм: учеб. пособие для вузов. - М.: Аспект Пресс, 2011. - 464 с.

10. Алексеева Н.Д. Особенности услуг охотничье-рыболовного туризма /Алексеева Н.Д. //Наука - промышленности и сервису. 2012. - № 6-3. - С. 179184.

11. Алексеева Ю.П. Деловой туризм России: проблемы, особенности развития / Ю.П. Алексеева, Л.Х. Джабраилова, А.А. Попанова //Экономика и предпринимательство. 2020. - № 3 (116). - С. 746-749.

12. Алексеев-Стасов П.М. Проблемы и перспективы развития велосипедного туризма в республике Саха (Якутия) / П.М. Алексеев-Стасов, С.И. Колодезникова //Арктика XXI век. Гуманитарные науки. 2019. - № 2 (18). -C. 3-12.

13. Алиакберова Э.Р. Спортивно-экстремальный туризм в России и за рубежом / Э.Р. Алиакберова, Я.А. Луценко, А.А. Романова // Географические науки и образование: материалы IX Всероссийской научно-практической конференции. - Астрахань, 25 марта 2016 года. - С. 74-76.

14. Алибеков Ш.И. Перспективы развития горного туризма в Дагестане / Ш.И. Алибеков, М.А. Исмаилова // Актуальные проблемы развития туризма и индустрии гостеприимства: Сборник научных трудов Международной научнопрактической конференции. - Казань, 10 октября 2018 года. - С. 13-15.

15. Анализ травматизма в спортивном туризме на водных дистанциях / Соловьев Михаил Максимович, Феофанов Владимир Владимирович, Давыдов Максим Васильевич, Филатов Антон Олегович // Ученые записки университета им. П.Ф. Лесгафта. 2020. - № 12 (190). - С. 234-237.

16. Ангелина И.А. Оценка инвестиционной привлекательности развития промышленного туризма / И.А. Ангелина, В.Г. Антонец // Курортнорекреационный комплекс в системе регионального развития: инновационные подходы. 2016. - № 1. - С. 435-438.

17. Андрианов В.И. Проблемы развития внутреннего и въездного туризма / В.И. Андрианов // Современные проблемы сервиса и туризма. 2015. - №3. С. 5-10. 
18. Анисимова Е.Ю. Развитие детского пешего туризма в Ульяновской области /Анисимова Е.Ю., Канцерова И.Е. // Трешниковские чтения 2019. Современная географическая картина мира и технологии географического образования. Материалы международной научно-практической конференции, посвященной памяти знаменитого российского океанолога, исследователя Арктики и Антарктики, академика Алексея Фёдоровича Трёшникова. Под. редакцией И.Н. Тимошиной, Е.Ю. Анисимовой, Е.А. Артемьевой. - Ульяновск, 03-05 апреля 2019 года. - С. 73-74.

19. Арутюнян С.А. Рыболовно-охотничий туризм и его роль в развитии рынка туристских услуг / С.А. Арутюнян //Инновации. Менеджмент. Маркетинг. Туризм. 2013. - № 1. - С. 70-73.

20. Арцис Е. Особенности лыжных походов / Е. Арцис // Турист. 1972. № 11. - C. 25.

21. Атаев А.Г. Влияние туристического бизнеса на сокращение безработицы / А.Г. Атаев //Государственная служба. 2011. - № 3 (71). - С. 115 117.

22. Атаев М.Д. Развитие страхования в сфере туризма в Российской Федерации / М.Д. Атаев //Новая наука: Теоретический и практический взгляд. 2016. - № 4-1 (75). - С. 4-7.

23. Байбулдина А.А. Проблемы и перспективы развития экстремального туризма // Вестник УГУЭС. Наука, образование, экономика. Сер. Экономика. 2013. - № 3 (5). - С. 41-43.

24. Байков А.В. Инновационные аспекты системного подхода к обеспечению безопасности туристов на круизных судах / Е.А. Байков // Туризм в современном мире: направления и тенденции развития: Материалы IV Всероссийской научно-практической конференции с международным участием, посвящённой 10-летию кафедры «Социально-культурный сервис и туризм». Под редакцией В.А. Чернова. - Хабаровск, 28-29 марта 2013 года. - С. 316-319.

25. Бакулева В.С. Экстремальные виды туризма как одно из популярных направлений современного туризма / В.С. Бакулева, А.В. Кутышева // Проблемы, опыт и перспективы развития туризма, сервиса и социокультурной деятельности в России и за рубежом: Материалы IV Международной научнопрактической интернет-конференции. Забайкальский государственный университет; Ответственный редактор О.А. Лях. Байбулдина А.А. Проблемы и перспективы развития экстремального туризма - Чита, 29-30 ноября 2017 года. - C. 162-166. 
26. Балашов А.Н. Охотничий туризм как перспективное направление развития туристической индустрии сибирского региона / А.Н. Балашов // Конкурентный потенциал региона: оценка и эффективность использования: Сборник статей $\mathrm{X}$ Международной научно-практической конференции. Ответственный редактор Н.Ф. Кузнецова. - Абакан, 07-08 ноября 2019 года. C. $108-110$.

27. Балынин К.А. Аспекты диверсификации гастрономического туризма / К.А. Балынин // Сервис в России и за рубежом. 2017. -Том 11. - №1. -C. 97-108.

28. Барабанова М.И. Актуальность предоставления услуг парусного туризма в России / М.И. Барабанова, И.И. Чикова // Актуальные проблемы развития сферы услуг: Сборник научных трудов. Под ред. Ю.В. Долматеня, В.А. Ткачева. - Санкт-Петербург, 2018. - С. 5-13.

29. Барабанова П.С. Гражданско-правовое регулирование договорных отношений в сфере туризма в России и Англии: автореф. дис.. канд. юрид. наук / П.С. Барабанова. - М., 2017. - 26 с.

30. Баранов С.Д. Проблемы и перспективы развития водного туризма в республике Крым и г. Севастополе / С.Д. Баранов // Проблемы и перспективы развития туризма в Южном федеральном округе: сб. науч. тр. - Симферополь: ИТ «Ариал», 2016. - С. 254-257.

31. Басюк Д.И. Теоретические и прикладные основы формирования дестинаций винного туризма / Д.И. Басюк. - Каменец-Подольский: ЧП Д.Г. Зволейко, 2014. - 272 с.

32. Басюков Г.Т. Круизный туризм: особенности и тенденции в 2018 году / Г.Т. Басюков //Эпоха науки. 2018. - № 14. - С. 107-112

33. Бахсыров Ю.Ю. Велосипедный туризм в республике Саха (Якутия) / Ю.Ю. Бахсыров, М.В. Лисагор //Символ науки: международный научный журнал. 2016. - № 12-1 (24). - С. 46-48.

34. Бекешев А.Ю. Безопасность автобусных перевозок в туризме / А.Ю. Бекешев // Туризм и гостеприимство сквозь призму инноваций: Сборник статей III научно-практической конференции. Под научной редакцией Е.М. Крюковой. - Москва, 27 февраля 2018 года. - С. 27-28.

35. Белентьева Т.Н. Анализ состояния промышленного туризма в Приморском крае / Т.Н. Белентьева, Я.С. Нарута //Вестник современной науки. 2015. - № 11-2 (11). - С. 23-28.

36. Бердник К.М. Состояние круизного туризма в экономике России / К.М. Бердник, Е.Е. Рассказова // Предпринимательство в современной России: 201 
Сборник статей II Всероссийской научно-практической конференции. Под научной редакцией Г.И. Андрющенко. - Москва, 19 января 2020 года. - С. 30-33.

37. Берман А. Е. Путешествие на лыжах / А. Е. Берман - М.: ФиС, 1968. $128 \mathrm{c}$.

38. Биржаков М.Б. Безопасность в туризме / М.Б. Биржаков, Н.П. Казаков - СПб: «Издательский дом Герда», 2007. - 208 с.

39. Бобков М.А. О страховании гражданской ответственности за неисполнение и ненадлежащее исполнение обязательств по договору о реализации туристского продукта (международный и зарубежный опыт) / М.А. Бобков //Международное публичное и частное право. - 2011. - № 2. - С. $27-30$.

40. Бобкова А.Г. Безопасность туризма / А.Г. Бобкова, С.А. Кудреватых, Е.Л. Писаревский / под общ. ред. Е. Л. Писаревского. - М.: Федеральное агентство по туризму. 2014. $-272 \mathrm{c}$.

41. Бобылев В.Ю. Альпинизм и его роль в развитии туризма / В.Ю. Бобылев //Вестник спортивной истории. 2015. - № 1. - С. 58-75.

42. Бойназаров У.Э Обеспечение безопасности туристов в средствах размещения / У.Э. Бойназаров //Вопросы науки и образования. 2019.№ 18 (65). - С. 31-34.

43. Бондаренко С.А. Винный туризм: дань вековым традициям и PR-кампания в одном бокале / С.А. Бондаренко //Знание. 2016. - № 5-2 (34). C. 20-23.

44. Борисов А.Н. Налог на игорный бизнес: Коммент. к гл. 29 ч. 2 Налогового кодекса РФ / А.Н. Борисов. - М.: Юстицинформ, 2004. - 111 с.

45. Борисова А.В. Деловой туризм как перспективное направление развития туризма в России / А.В. Борисова // Туризм и сервис в России: проблемы и перспективы развития. Студенческая научно-практическая конференция. - Черкизово, 30 марта 2015 года. - С. 13-15.

46. Борисова И.С. Развитие механизма диверсификации экономики региона, характеризующейся преобладанием определенного вида хозяйственной деятельности, для повышения стратегической устойчивости территории / И.С. Борисова //Управление экономическими системами: электронный научный журнал. 2015. - № 4 (76). - С. 10.

47. Босси Е.А. Институт страхования как инструмент защиты прав корпоративных предприятий и потребителей в сфере туризма / Е.А. Босси // Молодой ученый. 2017. - № 6 (140). - С. 331-333. 
48. Братановский С.Н. Правовые основы международного туризма / С.Н. Братановский // Туризм: право и экономика. 2015. - № 4. - С. 3-8.

49. Бузякова И.В. Влияние метеорологических факторов южных регионов на развитие летних видов туризма и отдыха / И.В. Бузякова //Геология, география и глобальная энергия. 2019. - № 4 (75). - С. 137-145.

50. Букреева К.С. Туризм как средство оздоровления / К.С. Букреева, Е.С. Двойникова // Актуальные проблемы физического воспитания студентов: Сборник материалов II Международной студенческой научно-практической конференции. - Чебоксары, 2018. - С. 18-20.

51. Булашев А.Я. Лыжный туризм - один из потенциально опасных и экстремальных видов спортивного туризма / А.Я. Булашев //Вестник Академии детско-юношеского туризма и краеведения. 2014. - № 1 (110). - С. 6-18.

52. Булашев А.Я. Особенности спортивного туризма как вида спорта на примере лыжных спортивных походов / А.Я. Булашев, Ю.Л. Шальков // Педагогика, психология и медико-биологические проблемы физического воспитания и спорта. - 2007. - № 6. - С. 43-47.

53. Бурыкин А.А. Особенности страхования персональных рисков в сфере туризма / А.А. Бурыкин, В.С. Спиридонова //Вестник Национальной академии туризма. 2008. - № 3 (7). - С. 25-28.

54. Бутенко Т.В. Профессиональная ориентация молодежи средствами спортивно-оздоровительного туризма / Т.В. Бутенко, Е.Ю. Шутьева, В.Н. Нагорных, В.А. Сорокин // Современный ученый. - 2019. - № 1.-С. 47-51.

55. Быкова Е.А. Влияние туризма на экономику стран / Е.А. Быкова, И.В. Фомин // Туризм и гостеприимство сквозь призму инноваций: Сборник статей III научно-практической конференции. Под научной редакцией Е.М. Крюковой. - Москва, 27 февраля 2018 года. - С. 28-32.

56. Бырдин В.С. Радиационная безопасность туриста / В.С. Бырдин, О.М. Цеханович // Образование. Наука. Культура. Материалы V Международной научно-практической конференции. - Гжель, 22 ноября 2013 года. - С. 475-486.

57. Вагабов М.M. Перспективы развития спортивно-рыболовного туризма в горном Дагестане / М.М. Вагабов // Эффективное развитие горных территорий России. Горный форум - 2016: материалы международной научнопрактической конференции. - Ставрополь, 04-05 октября 2016 года. - С. 330335 . 
58. Валитова Т.А. Теоретический аспект диверсификации хозяйственной деятельности региона как основы его социально-экономического развития / Т.А. Валитова //Конкурентоспособность в глобальном мире: экономика, наука, технологии. 2016. - № 9-1 (23). - С. 48-50.

59. Васецкий В.Н. Гражданско-правовые средства защиты в сфере туризма / В.Н. Васецкий //Законодательство и экономика. - 2011. - № 6. C. 49-54.

60. Васильев А.В. Задачи, объекты и перспективы развития научного туризма в Бурятии / А.В. Васильев, А.Н. Пивоваров // Инновации в отраслях народного хозяйства, как фактор решения социально-экономических проблем современности: сборник докладов и материалов VI Международной научнопрактической конференции. АНО ВО «Институт непрерывного образования». Москва, 09-10 декабря 2016 года. - С. 339-346.

61. Васильева А.А. Экологический туризм и экологическое воздействие туризма / А.А. Васильева, А.А. Матвеева // Экология и здоровье человека. Гармония с окружающим миром: Материалы научно-практической конференции. - Чебоксары, 15 ноября 2017 года. - С. 103-107.

62. Вахрушев И.Б. К вопросу о создании игорной зоны в Крыму / И.Б. Вахрушев, Г.А. Заславский //Ученые записки Крымского федерального университета имени В.И Вернадского. География. Геология. 2018. - Т. 4 (70). № 2. - С. 25-32.

63. Винокурова М.С. Перспективы развития летнего активного туризма в Кузбассе / М.С. Винокурова, К.А. Орлова, О.А. Видина // Россия молодая: Сборник докладов студентов, аспирантов и профессорско-преподавательского состава Кузбасского государственного технического университета по результатам II Всероссийской, 55 научно-практической конференции. Кемерово, 12-16 апреля 2010 года. - С. 292-295.

64. Влияние делового туризма на туристско-рекреационный потенциал региона / Ю.П. Алексеева, В.М. Ибрагимова, Ш.Ш. Галимов // Научнопрактические исследования. 2020. - № 5-1 (28). - С. 5-8.

65. Влияние спортивных форумов на въездные туристические потоки / И.П. Кульгачев, Е.Ю. Сысоева, М.М. Романова, Ю.И. Кульгачев, А.Н. Рогозина // Ученые записки университета им. П.Ф. Лесгафта. 2020. - № 8 (186). - С. 175 181.

66. Водневская Г.В. Лыжная подготовка и туризм как средство воспитания подростков / Г.В. Водневская // XV Бушелевские чтения: сборник 204 
материалов научно-практической конференции. - Петропавловск-Камчатский, 23-25 марта 2016 года. - С. 63-65.

67. Возисова М.А. Концепция формирования компетенций безопасности туристской деятельности у бакалавров физической культуры / М.А. Возисова // Известия Тульского государственного университета. Педагогика. 2017. - № 1. C. 59-64.

68. Возисова М.А. Практические рекомендации в формировании компетенций безопасности туризма у будущих бакалавров физической культуры / М.А. Возисова, Т.Н. Шутова //Ученые записки университета им. П.Ф. Лесгафта. 2017. - № 6 (148). - С. 43-47.

69. Возисова М.А. Формирование компетенций безопасности туристской деятельности в подготовке бакалавров физической культуры / М.А. Возисова, Т.Н. Шутова // Новое слово в науке: перспективы развития. 2016. - № 4-1 (10). - C. $85-88$.

70. Воинова Н.Е. Особенности развития охотничьего туризма на территории России / Н.Е. Воинова, Е.А. Нелепина // Научный альманах Центрального Черноземья. 2015. - № 1. - С. 92-95.

71. Волков С.К. Генезис туристического маркетинга как области научного знания в теории маркетинга / С.К. Волков //Вестник Кемеровского государственного университета. Серия: Политические, социологические и экономические науки. 2018. - № 4. - С. 33-46.

72. Волостных В.В. Яхтинг, туризм и государственное управление / В.В. Волостных // Развитие российской системы государственного управления: реалии современности, тенденции, перспективы: материалы II междунар. науч.-практ. конф. (23-25 октября 2017 г.). - Калининград: Аксиос, 2017. C. $170-175$.

73. Волошин Н.И. Правовое регулирование в туризме: учебник. 3-е изд., испр. и доп. / Н.И. Волошин - М.: Советский спорт, 2007. - 504 с.

74. Волхонская Г.П. Экстремальный туризм России: проблемы и перспективы развития / Г.П. Волхонская // Научные труды Сибирского государственного университета физической культуры и спорта. 2016. - Т. 2016. - C. $77-81$.

75. Волчек Д.Д. Туристический маркетинг / Д.Д. Волчек, А.А. Пузыревская // Научное знание современности. 2020. - № 1 (37). - С. 6-9.

76. Воробьева Д.Е. Туристическая полиция в РФ и мировой опыт / 205 
Д.Е. Воробьева, Е.В. Дегтева //Российские регионы: взгляд в будущее. 2019. Т. 6. - № 2. - С. 137-149.

77. Ворожко Ю.В. Формирование туристских услуг в развитии экологического и охотничье-рыболовного туризма в Тюменской области / Ю.В. Ворожко, Е.С. Любина // Совершенствование системы физического воспитания, спортивной тренировки, туризма и оздоровления различных категорий населения: Материалы $\mathrm{X}$ Международной научно-практической конференции. В 2-х томах. Под редакцией С.И. Логинова. - Сургут, 2011. C. $36-37$.

78. Газмагамаев М.М. Горный туризм в Чечне и способы дальнейшего развития / М.M. Газмагамаев // Вестник Комплексного научноисследовательского института им. Х.И. Ибрагимова РАН. 2020. - № 1 (1). - С. $39-44$.

79. Галачиева Л.А. Экстремальный туризм: пути и перспективы развития на Центральном Кавказе / Л.А. Галачиева, С.И. Шагин // Известия Дагестанского государственного педагогического университета. Естественные и точные науки. 2015. - № 2. - С. 105-109.

80. Галачиева Л.А. Развитие альпинизма и горнолыжного спорта в Кабардино-Балкарии / Л.А. Галачиева - Нальчик: Принт Центр, 2012. - 294 с.

81. Гарнов А.П. Актуальность системного формирования отечественного промышленного туризма / А.П. Гарнов, О.В. Краснобаева // Вестник Российского экономического университета имени Г.В. Плеханова. 2012.№ 2 (44). - С. 60-63.

82. Голованова Д.А. Сервис по прогнозированию повторных продаж туристических услуг / Д.А. Голованова //Хроноэкономика. 2020. - № 3 (24). C. $86-92$.

83. Головач Э.П. Тенденции развития промышленного туризма в мире / Э.П. Головач, Е.Н. Хутова // Вестник Брестского государственного технического университета. Экономика. 2018. - № 3 (111). - С. 10-14.

84. Голомолзин Е. Автобусный вояж: достоинства и недостатки / Е. Голомолзин // Турбизнес. 2013. - № 6. - С. 24-25.

85. Голубев С.В. Научный туризм - вид активного отдыха не только для интеллектуалов / С.В. Голубев - М.: КНОРУС, 2013. - 448 с.

86. Григорьева Д.К. Яхтинг как новый тренд в развитии регионального туризма Камчатского края / Д. К. Григорьева // Стратегия устойчивого развития регионов России. - 2016. - № 35. - С. 129-134. 
87. Гришина И.В. Перспективы диверсификации внешнеэкономической деятельности забайкальского края / И.В. Гришина, А.В. Котов //Российский внешнеэкономический вестник. 2018. - № 11. - С. 72-86.

88. Губа В.П. Активный туризм как средство социального воспитания и оздоровления населения / В.П. Губа, О.А. Сахарова // Теория и практика физической культуры. 2007. - № 6. - С. 79.

89. Губаненков C.M. Зачем нужен детям лыжный туризм / С.М. Губаненков //Вестник Академии детско-юношеского туризма и краеведения. 2014. - № 1 (110). - С. 112-114.

90. Гужова Л.Г. Специфика популяризации велосипедного туризма в мире / Л.Г. Гужова, А.А. Наймушина //Вестник науки. 2020. - Т. 3. - № 5 (26). C. $30-35$.

91. Гуляев П.Д. К вопросу корректности определения понятий "спортивный туризм" и "спортивный тур" в терминологии спортивнооздоровительного туризма / П.Д. Гуляев, А.Е. Тарасов // Физическая культура, спорт, наука и образование: Материалы II всероссийской научной конференции. Под редакцией С.С. Гуляевой, А.Ф. Сыроватской. - Якутск, 30 марта 2018 года. - С. 140-146.

92. Гулян С.С. Страхование от невыезда в сфере туризма: проблемы правоприменения / С.С. Гулян, Л.Г. Джинджолия // Социально-экономическое развитие России: актуальные подходы и перспективные решения: Сборник научных трудов студентов. - Краснодар, 14-15 мая 2020 года. - С. 137-143.

93. Гусейнов Р.Г Применение средств туризма в формировании здорового образа жизни и профессиональной подготовке студентов физкультурного факультета / Р.Г. Гусейнов, О.М. Омаров // Проблемы теории и практики развития физической культуры и спорта на современном этапе: Материалы X Всероссийской научно-практической конференции. Под редакцией Ш.О. Исмаилова. - Махачкала, 27 октября 2020 года. - С. 178-180.

94. Гуськов В.М. Массовый туризм как путь оздоровления нации / В.М. Гуськов, А.И. Дрожжаков // Фитнес-аэробика - 2016: Материалы Всероссийской научной интернет-конференции. - М., 2016. - С. 141-143.

95. Дегтярёва Т.В. Конный туризм в контексте развития туризма в Ростовской области / Т.В. Дегтярёва, А.А. Пасечникова // Научная весна-2018. Экономические науки: Сборник научных трудов. Научное электронное издание. - Шахты, 2018. - С. 240-247. 
96. Дегтярёва Т.В. Организационно-технологические аспекты развития делового туризма / Т.В. Дегтярёва, И.В. Борисенко //Экономика и предпринимательство. 2018. - № 5 (94). - С. 736-741.

97. Демачева К.В. Анализ динамики развития международного туризма в России / К.В. Демачева, О.Н. Кострюкова //Современные аспекты экономики. 2016. - № 5. - С. 95-101.

98. Деньщик А.С. Проблемы и тенденции развития круизного туризма в РФ / А.С. Деньщик, О.А. Алексеева // Исследование, систематизация, кооперация, развитие, анализ социально-экономических систем в области экономики и управления (ИСКРА - 2018): Сборник трудов I Всероссийской школы молодых ученых. Под общей редакцией В.М. Ячменевой. - 2018. C. 261-265.

99. Добрейцина Л.Е. Промышленный туризм в Свердловской области: основные векторы развития (на материале официальных документов) / Л.Е. Добрейцина // Известия Уральского федерального университета. Серия 1: Проблемы образования, науки и культуры. 2020. - Т. 26. - № 1 (195). - С. 200 209.

100. Домничева А.А. Экстремальный туризм как инновационная тенденция современного туризма / А.А. Домничева // Инновационные стратегии развития педагогического образования: сборник научных трудов Тринадцатой Международной очно-заочной научно-методической конференции: в 2 частях. - Саратов, 13 апреля 2017 года. - С. 124-127.

101. Дубровин Н. Страхование в туризме: итоги изменений законодательства / Н. Дубровин // Новое законодательство и юридическая практика. 2009. - №2.

102. Ерланкызы А. Развитие экстремального туризма в Мангистауской области Казахстана / А. Ерланкызы //Молодой ученый. 2020. - № 5 (295). C. 358-360.

103. Ёров Дж. Н. Влияние туризма на экономическое развитие или влияние экономики на туризм / Дж. Н. Ёров //Вестник Таджикского национального университета. Серия социально-экономических и общественных наук. 2016. - № 2/4 (204). - С. 24-32.

104. Ефимов О.В. Безопасность туризма / О.В. Ефимов // Туризм: право и экономика. 2013. - № 3. - С. 8-11.

105. Ефремов А.В. Выживание как составная часть жизнедеятельности 208 
туристов в походах и попавших в зоны горячих точек и районы социального напряжения местного населения / А.В. Ефремов, Л.Б. Хрущева // Компетентностный вектор: новые реалии и возможности для сферы услуг: Материалы Всероссийской научно-практической конференции. отв. ред. Т.И. Клименко, И.С. Кабиров. - Казань, 27 декабря 2017 года. - С. 25-32.

106. Жегалина Г.В. Туризм - путь к оздоровлению населения страны / Г.В. Жегалина, Э.В. Жегалина // Градостроительство. 2018. -№6 (58).-С. 79-84.

107. Жмулина Д.А. Правовое регулирование деятельности по оказанию гостиничных услуг: Автореф. дисс. ... канд. юрид. наук / Д.А. Жмулина - СПб, 2009. - C. 23.

108. Жохова В.В. Конные туры как перспективное направление активных видов туризма Приморского края / В.В. Жохова, Е.Н. Соловьева // Молодой учёный. 2013. - № 12. - С. 290-292.

109. Жуков П.В. Современные проблемы и тенденции развития водного туризма в Санкт-Петербурге / П.В. Жуков, О.Н. Морозова, С.Г. Шкуропат // Сервис plus. - 2018. - Т. 12. - № 2. - С. 14-23.

110. Жукова Ю.С. Обоснование хозяйственных решений организации по диверсификации деятельности / Ю.С. Жукова //Стратегия предприятия в контексте повышения его конкурентоспособности. 2018. - № 7. - С. 216-220.

111. Заброда Д.Г. "Туристическая" полиция в республике Крым: аргументы "за" и "против" / Д.Г. Заброда, А.В. Гурченко // Обеспечение общественной безопасности и противодействие преступности: задачи, проблемы и перспективы: Материалы Всероссийской научно-практической конференции. - Краснодар, 23 июня 2017 года. - С. 206-210.

112. Заброда Д.Г. Туристическая полиция: зарубежный опыт и перспективы его внедрения в России / Д.Г. Заброда // Актуальные проблемы науки и практики. Сборник научных трудов. - Хабаровск, 2018. - С. 82-87.

113. Завьялова С.В. Возмещение вреда, причиненного жизни и здоровью туриста: дискуссионные вопросы / С.В. Завьялова //Наука и современность. 2014. - № 28. - C. 275-287.

114. Задевалова С.В. Экологический туризм как фактор устойчивого развития территорий / С.В. Задевалова, Т.Г. Бутова, В.И. Задевалов // Вестник БГУ. 2013. - № 13. - С. 53-56.

115. Закамская Л. Л. Экологический туризм как фактор развития региона / Л.Л. Закамская, О.В. Секлецова, О.С. Кузнецова // МНКО. 2012. - № 3. - 361363. 
116. Захарова Е.П. Туристическая полиция в России: практический опыт и перспективы развития / Е.П. Захарова // Публичная власть: реальность и перспективы: сборник научных трудов по материалам второй ежегодной Международной научно-практической конференции. - Саратов, 01 ноября 2015 года. - С. 54-56.

117. Зиганшин И.И. Влияние экономических санкций на развитие российского туризма / И.И. Зиганшин, А.О. Овчаров, М.А. Рысаева // Актуальные проблемы экономики и права. 2015. - № 1. - С. 17-25.

118. Иванов А.А. Туристическая полиция МВД России / А.А. Иванов, Н.Д. Эриашвили // Закон и право. 2018. - № 2. - С. 38-40.

119. Иванова Е.В. Парусный туризм как вид экологичного туризма / Е.В. Иванова // Экология: синтез естественно-научного, технического и гуманитарного знания: материалы III Всероссийского научно-практического форума и I Школы интерэкоправа. Саратов, 10-13 октября 2012 года. - С. 240241.

120. Иванцова Т.М. Об обязанностях туристских организаций по обеспечению безопасности туристов / Т.М. Иванцова // Современное состояние и потенциал развития туризма в России: сборник статей ХI Международной научно-практической конференции. под общей редакцией Д.П. Маевского. Омск, 26-27 ноября 2014 года. - С. 131-132.

121. Иванько И.В. Туристическая полиция Российской Федерации: современные тенденции организации и деятельности / И.В. Иванько // Научные труды Тюменского института повышения квалификации сотрудников МВД России (к 25-летию Конституции Российской Федерации). - Тюмень, 2018. C. $153-167$.

122. Игбаев Г.Р. Личное страхование туристов, выезжающих за рубеж / Г.Р. Игбаев // Туризм: право и экономика. 2006. - № 5. - С. 30-31.

123. Изготовления текстильных изделий с регулируемым температурным режимом для зимнего туризма и отдыха / О.В. Ковалева, И.В. Рыбаулина, А.П. Неоронова, А.С. Дембицкая // Современные инженерные проблемы в производстве товаров народного потребления: Сборник научных трудов Международного научно-технического симпозиума, Международного Косыгинского форума. - Москва, 29-30 октября 2019 года. - С. 134-138.

124. Ильина С.А. Современные тенденции развития спортивного и оздоровительного туризма / С.А. Ильина, Т.Н. Демочкина, В.В. Донцов //Наука-2020. 2016. - № 4 (10). - С. 152-158. 
125. Ильяшенко И.Е. Объективные и субъективные опасности в туристских экспедициях с подростками 12-17 лет / И.Е. Ильяшенко, Д.В. Смирнов // Актуальные вопросы состояния и развития детско-юношеского и спортивно-оздоровительного туризма: Сборник научных статей по материалам Международной научно-практическая конференция, (15 декабря 2019 года, г. Москва. Российская Федерация) /сост. и науч. ред. И.А. Дрогов, Д.В. Смирнов. - М.: ООО "Издательство "Радуга-Пресс", МОО "МАДЮТК". 2019. - С. $175-180$.

126. Имамаев Ш.Н. Астрономический туризм в республике Дагестан / Ш.Н. Имамаев // Аллея науки. 2019. - Т. 1. - № 1 (28). - С. 216-220.

127. Имангулова Т.В. Горный туризм как вид активного отдыха / Т.В. Имангулова, Л.С. Нусупова, Б.К. Закирьянов //Теория и методика физической культуры. 2018. - № 4 (54). - С. 135-141.

128. Имангулова Т.В. Общая классификация горного туризма и их краткая характеристика / Т.В. Имангулова, Л.С. Нусупова // Цифровые технологии: наука, образование, инновации: Материалы 1-ой Международной научно-практической конференции научно-педагогических работников и молодых ученых. Под ред. Олейник А.В., Зеленский А.А. - Москва, 13 ноября 2018 года. - С. 261-269.

129. Информационный бюллетень // Межпарламентская ассамблея государств - участников Содружества Независимых Государств. 2000. - № 25. - C. 213-239.

130. Исакаева А.П. Перспективы развития конного туризма в Астраханской области / А.П. Исакаева, Р.А. Утегенов, М.С. Безуглова // Экология России: на пути к инновациям. 2016. - № 13. - С. 58-60.

131. К вопросу о содержании понятия «туристская привлекательность» / Т.В. Дегтярёва, И.В. Борисенко, С.О. Черномырдина, А.В. Калашников // Проблемы и перспективы развития туризма в Юж. федер. округе: сб. науч. тр. Симферополь, 2016. - С. 23-27.

132. Кадыров Р.В. Промышленный туризм как креативный маркетинг / Р.В. Кадыров, Р.Г. Мударисов //Вестник Алтайской академии экономики и права. 2018. - № 8. - С. 88-94.

133. Калинина Л.Е. Государственное управление туризмом в Российской Федерации: Автореф. дисс. ... канд. юрид. наук / Л.Е. Калинина. - Ростов-наДону, 2007. - 22 c. 
134. Калоева 3.Ю. Экстремальный туризм в туристско-рекреационном комплексе региона / З.Ю. Калоева, К.М. Туаева // Междисциплинарные исследования: опыт прошлого, возможности настоящего, стратегии будущего: Сборник избранных статей международной научно-практической конференции. - Мельбурн, Австралия, 23 октября 2020 года. - С. 150-156.

135. Калужникова Е.А. Ритуально-игровые формы в современном экскурсионно-познавательном туризме / Е.А. Калужникова, Е.Ю. Николаева // Вестник Гуманитарного университета. 2015. - № 1 (8). - С. 73-79.

136. Канонистова 3.С. Тематический туризм: вина Европы / 3.С. Канонистова // Туризм и культурное наследие. - 2002. - Вып. 1. - С. 166176.

137. Каночкина Н.А. Организация общественных пространств в контексте развития промышленного туризма / Н.А. Каночкина, Д.Д. Попова // Системные технологии. 2020. - № 1 (34). - С. 77-83.

138. Каракетов А.К. Перспективы и возможности развития горного туризма города Карачаевска / А.К. Каракетов // Проблемы и инновации спортивного менеджмента, рекреации и спортивно-оздоровительного туризма: Материалы V Всероссийской научно-практической конференции. Под общей редакцией Г.Н. Голубевой. - Казань, 06 июня 2019 года. - С. 267-268.

139. Каримов А.А. Экстремальный туризм как средство профилактики девиантного поведения в подростково-юношеском возрасте / А.А. Каримов, О.Л. Подлиняев //Современный ученый. 2019. - № 6. - С. 20-23.

140. Карманова А.Е. МІСЕ-индустрия в структуре делового туризма: обзор российского и зарубежного опыта / А.Е. Карманова, А.А. Курочкина // Наука и бизнес: пути развития. 2019. - № 12 (102). - С. 231-234.

141. Каюмова Р.Ф. Современная одежда для лыжного туризма и активного отдыха / Р.Ф. Каюмова, Т.Д. Пичужкина // Новая наука: история становления, современное состояние, перспективы развития: сборник статей Международной научно-практической конференции. - Уфа, 15 сентября 2017 года. - С. 15-18.

142. Кластерная модель, как инновации развития промышленного туризма / А.В. Гладилин, В.А. Гладилин, А.В. Нестеренко, А.С. Головченко // Финансовая экономика. 2018. - № 5. - С. 669-671.

143. Клейменова Е.О. Диверсификация экономики моногородов за счет развития промышленного туризма / Е.О. Клейменова, А.О. Чулакова // 
Инфраструктурные отрасли экономики: проблемы и перспективы развития. 2014. - № 7. - C. 20-26.

144. Кобец П.Н. О проблеме безопасности и защиты в туризме в условиях середины второго десятилетия XXI столетия / П.Н. Кобец // Туризм: право и экономика. 2017. - № 1. - С. 9-11.

145. Кобец П.Н. Особенности обеспечения безопасности сферы туризма подразделениями туристической полиции ряда государств Ближнего Востока и Юго-Восточной Азии / П.Н. Кобец //Туризм: право и экономика. 2019. - № 2. C. 22-24.

146. Кобец П.Н. Международные правовые проблемы обеспечения безопасности в туристической сфере / П.Н. Кобец // Глобальная экономика в XXI веке: роль биотехнологий и цифровых технологий: сборник научный статей по итогам работы шестого круглого стола с международным участием. M., 2020. - C.113-114.

147. Кобец П.Н. Опыт работы подразделений туристической полиции в государствах постсоветского пространства / П.Н. Кобец // Туризм: право и экономика. 2020. - N 4. - С. 25-28.

148. Кобец П.Н. Правовое регулирование оказания гостиничных услуг, классификации и стандартизации: история и современность. / П.Н. Кобец //Туризм: право и экономика. 2019. - № 3. - С. 8-10.

149. Кобец П.Н. Совершенствование антитеррористических мер безопасности на объектах транспорта / П.Н. Кобец // Научный портал МВД России. 2020. - N 1 (49). - С. 35-45.

150. Кобец П.Н. Современные правовые подходы к регулированию безопасности в сфере туризма Российской Федерации. / П.Н. Кобец //Туризм: право и экономика. 2018. - № 3. - С. 22-25.

151. Кобец П.Н. Становление подразделений туристической полиции (милиции) в государствах - участниках Содружества независимых Государств / П.Н. Кобец // Туризм: право и экономика. 2020. - N 1. - С. 30-32.

152. Ковальчук А.Н. Особенности развития охотничьего туризма в условиях экологического кризиса / А.Н. Ковальчук //Эпоха науки. 2020. - № 24. - C. $46-48$.

153. Ковтун Е.В. Игорный бизнес в России. Законодательное регулирование / Е.В. Ковтун. - СПб: Изд-во Р. Асланова: Юрид. центр Пресс, 2005. - $196 \mathrm{c}$. 
154. Ковтун Е.В. Налогообложение азартных игр: Игорный бизнес и арбитражная практика. Налогообложение интеллектуальных игр / Е.В. Ковтун. - М.: Налог-инфо: Статус-Кво 97, 2004. - 207 с.

155. Кожемяк Е.Ю. Велосипедный туризм: история, факторы развития / Е.Ю. Кожемяк //Научный вестник МГИИТ. 2017. - № 2 (46). - С. 49-53.

156. Козырева М.С. Особенности специфики детского водного туризма / М.С. Козырева //Синергия Наук. 2019. - № 35. - С. 132-138.

157. Колобова А.Е. Специфика водного туризма в современных условиях / А.Е. Колобова, С.С. Матвеев // Человеческий, производственный и сервисный потенциал экономики: глобальные тренды и локальные практики: Материалы Международной научно-практической конференции. 2020. C. 237-243.

158. Колодник Т.Д. Инфлюенс-маркетинг как вид интернет-маркетинга для продвижения туристических компаний / Т.Д. Колодник //Мир спорта. 2020. - № 2 (79). - C. 114-117.

159. Компетенции безопасности туристской деятельности в профессиональной подготовке бакалавров физической культуры / М.А. Возисова, Т.Н. Шутова, Т.В. Буянова, В.А. Зайцев // Известия Тульского государственного университета. Физическая культура. Спорт. 2018. - № 1. C. 20-27.

160. Коник Н.В. Игорный бизнес: бухгалтерский и налоговый учет: практ. пособие / Н.В. Коник, Н.Н. Яскевич. - М.: Омега-Л, 2008. - 124 с.

161. Конкурентоспособность и потенциал России на мировом рынке делового туризма / С.Г. Пьянкова, И.В. Митрофанова, О.Т. Ергунова, Е.И. Охрименко //Экономика: вчера, сегодня, завтра. 2019. - Т. 9. - № 9-1. - С. 291304.

162. Коновалова Е.Е. Спортивный исторический туризм как один из инновационных видов спортивного туризма / Е.Е. Коновалова, С.Ю. Седов // Научные исследования высшей школы по приоритетным направлениям науки и техники: сборник статей Международной научно-практической конференции. Пермь, 25 февраля 2018 года. - С. 101-104.

163. Коппель Д.С. Молодежь как фактор развития экстремального туризма в России / Д.С. Коппель, Т.Ю. Анисимов // Молодежный туризм в России: ресурсы, тенденции, перспективы: Сборник статей по материалам 1-й международной студенческой научно-практической конференции. - Санкт- 
Петербург, 2015. - С. 67-69.

164. Кораблев В.А. Спортивный туризм, его роль и место в современной классификации туризма / В.А. Кораблев // Россия и Европа: связь культуры и экономики: Материалы XXV международной научно-практической конференции. Отв. редактор Уварина Н.В. - Прага, 25 ноября 2019 года. C. 84-86.

165. Корсун Е.А. Современное состояние круизного туризма на юге России / Е.А. Корсун, Д.Н. Фокин //Курортно-рекреационный комплекс в системе регионального развития: инновационные подходы. 2017. - № 1. C. 136-139.

166. Костиков А.К. Комплексная модель объектов промышленного туризма / А.К. Костиков, Е.Н. Лихачёв //Творчество и современность. 2020. № 1 (12). - С. 27-34.

167. Кочетков Н.М. Эпидемическая безопасность туриста / Н.М. Кочетков //Успехи современного естествознания. 2007. - № 6. - С. 69-71.

168. Кочетков Н.М. Эпидемическая безопасность туриста / Н.М. Кочетков // Успехи современного естествознания. 2006. - № 9. - С. 57-59.

169. Кочкаров З.Ж. Развитие туризма, как решение проблемы безработицы в Кабардино-Балкарской республике / З.Ж. Кочкаров // Аллея науки. 2017. - Т. 3. - № 10. - С. 406-408.

170. Кошанов А.К. Теоретические аспекты диверсификации сферы туризма в современных условиях / А.К. Кошанов, Н.У. Багаева // Экономика: стратегия и практика. 2018. - № 3 (47). - С. 136-143.

171. Кошин И.И. Развитие делового туризма в Российской Федерации в 2000-е годы: тенденции, проблемы, перспективы / И.И. Кошин, О.В. Кошина // Огарёв-Online. 2020. - № 2 (139). - С. 7.

172. Кривцова Е.В. Перспективы формирования территориального бренда в сфере туризма в промышленном регионе с использованием специальных мероприятий / Е.В. Кривцова, А.В. Леутина, И.Ю. Рассохина // Реклама: теория и практика. 2018. - № 3. - С. 176-190.

173. Крылова Е.А. Научный туризм как одна из форм научной дипломатии России / Е.А. Крылова // Аллея науки. 2018. - Т. 1. - № 2 (18). C. 365-369.

174. Кудреватых С.А. О системе законодательства в сфере туризма / С.А. Кудреватых, А.С. Кудреватых // Туризм: право и экономика. 2015. - № 2. C. 3-8. 
175. Кузнецов Л. Обеспечение безопасности туристов в

Санкт-Петербурге / Л. Кузнецов // Туризм: право и экономика. 2011. - № 4. - С. $17-19$.

176. Кузнецова Е.И. Влияние международного туризма на национальную экономику стран мира / Е.И. Кузнецова // Электронный научный журнал. 2020. - № 4 (33). - С. 105-109.

177. Куклев В.А. Проблема развития велосипедного туризма в России / В.А. Куклев, И.Е. Евграфов // Проблемы и инновации спортивного менеджмента, рекреации и спортивно-оздоровительного туризма: Сборник материалов IV Всероссийской научно-практической конференции. Под общей редакцией Г.Н. Голубевой. - Казань, 07-08 июня 2018 года. - С. 354-356.

178. Куприна Л.Е. Экологический туризм и экологичность туризма в аспекте создания учебных экологических троп / Л.Е. Куприна //Интегративная перспектива в гуманитарных науках. 2015. - № 2. - С. 56-62.

179. Курбанова А.М. Гастрономические фестивали в индустрии гостеприимства республики Дагестан / A.M. Курбанова //Сервис plus. 2020. T. 14. - № 2. - С. 30-41.

180. Кусмаков С.Ю. Винный туризм как перспективное направление в развитии индустрии туризма Краснодарского края / С.Ю. Кусмаков // Научные исследования - основа современной инновационной системы: сборник статей по итогам Международной научно-практической конференции. - Челябинск, 28 апреля 2019 года. - С. 187-189.

181. Кухарская Е.Ю. Туризм как фактор экономического развития в Российской Федерации / Е.Ю. Кухарская // Приоритетные направления и проблемы развития внутреннего и международного туризма в России: Материалы I Всероссийской с международным участием научной конференции. - Алушта, 26-27 апреля 2018 года. - С. 14-18.

182. Кучина О.В. Сельский туризм как эффективный инструмент повышения занятости населения на сельских территориях и патриотического воспитания молодежи / О.В. Кучина, М.Д. Кучина // Вестник Орловского государственного университета. Серия: Новые гуманитарные исследования. 2015. - № 2 (43). - С. 262-265.

183. Лапинова С.А. Анализ факторов, влияющих на доход от туристической деятельности в регионах / С.А. Лапинова, Д.О. Липатов // Российский экономический интернет-журнал. 2017. - № 1. - С. 23. 
184. Лапшина А.Е. Экологический туризм и законодательство России / А.Е. Лапшина // Сервис в России и за рубежом. 2008. -№ 2. -С. 93-99.

185. Латорцев А.А. Особенности планирования показателя конкурентоспособности в индустрии туризма / А.А. Латорцев, Ю.С. Белоусова // Вестник Московского финансово-юридического университета. 2018. - № 3. C. $96-108$.

186. Латушко Н.А. Ценовая политика хостелов в крупных городах (на примере юга России) / Н.А. Латушко, В.В. Гнездилова, Д.А. Рубан // Вестник УрФУ. Серия экономика и управление. 2016. - № 4. -С. 462-485.

187. Левченко Г.Н. Прогнозно-аналитические методы оценивания влияния проведения масштабных спортивных соревнований на динамические характеристики туристических потоков современных мегаполисов / Г.Н. Левченко, О.С. Зайцев, А.В. Гарцев //Актуальные исследования. 2020.№ 17 (20). - С. 93-96.

188. Ленкова М.И. Конгрессно-выставочный туризм - динамично развивающийся сектор делового туризма / М.И. Ленкова, Е.Г. Марченко // Курорты. Сервис. Туризм. 2014. - № 3-4 (24-25). - С. 63-69.

189. Леонидова Е.Г. Оценка влияния сферы туризма на экономику на основе метода межотраслевого баланса / Е.Г. Леонидова //Вестник Белгородского университета кооперации, экономики и права. 2017. - № 4 (65). - C. 281-290.

190. Летний туризм в контексте будущих изменений климата России: оценки по большому ансамблю условных прогнозов высокого разрешения / М.В. Клюева, И.М. Школьник, Ю.Л. Рудакова, Т.В. Павлова, В.М. Катцов // Метеорология и гидрология. 2020. - № 6. - С. 47-59.

191. Литвинов А.Е. Основные особенности водного туризма и пути его развития в горно-предгорной части Краснодарского края / А.Е. Литвинов // Курортно-рекреационный комплекс в системе регионального развития: инновационные подходы. 2011. - № 1. - С. 188-191.

192. Логвина Е.В.Проблемы сезонности в туризме и пути их преодоления в условиях санкционной политики в Крыму / Е.В. Логвина // Геополитика и экогеодинамика регионов. 2018. - Том 4 (14). - Вып. 2. - С. 108 116.

193. Логунов А.Ю. Государственная политика и безопасность в сфере туризма / А.Ю. Логунов // Проблемы безопасности российского общества. 2011. - № 1. - C. 118-122. 
194. Логунова Н.А. Экономическая оценка социальной эффективности круизного туризма / Н.А. Логунова / Економічний форум. 2013. - № 3. - С. 231238.

195. Лощинина А.М. Обеспечение экологической безопасности туристов на территории Чукотского автономного округа / А.М. Лощинина, Е.О. Решетникова // Новая наука: Современное состояние и пути развития. 2016. -№ 12-4. - С. 6-10.

196. Лысенко В.В. Организация туристской индустрии: учеб. пособие / В.В. Лысенко - Белгород: Изд-во БУКЭП, 2014. - 34 с.

197. Любарская М.А. Факторы развития экологического, экстремального и научного туризма в полярных областях / М.А. Любарская, А.Н. Любарский // Теория и практика сервиса: экономика, социальная сфера, технологии. 2013.№ 4 (18). - С. 175-183.

198. Макаров И.Б. Комплексный подход к проблеме безопасности в туризме / И.Б. Макаров // Научный вестник МГИИТ 2013. - № 6. - С. 22-26.

199. Маклашина Л.Р. Деловой туризм - инструмент продвижения индустрии туризма / Л.Р. Маклашина // Актуальные вопросы экономических наук: Материалы Международной научной конференции. - Уфа, 20-23 октября 2011 года. - С. 122-125.

200. Маклашина Л.Р. Развитие водного туризма в Нижегородской области / //Молодой ученый. 2011. - № 8-1. - С. 154-156.

201. Макринова Е. И. Основы индустрии гостеприимства: учеб. пособие / Е. И. Макринова, Т. Ю. Иваницкая. - Белгород: Изд-во БУКЭП, 2012. - 265 с.

202. Макринова Е.И. Мониторинг лояльности персонала, занятого в сфере туризма, и основные направления ее диверсификации / Е.И. Макринова, В.В. Лысенко //Вестник Белгородского университета кооперации, экономики и права. 2017. - № 1 (62). - С. 34-46.

203. Макринова Е.И. Управление персоналом в гостиничном комплексе: учеб. пособие / Е. И. Макринова, М. Г. Иваненко. - Белгород: Изд-во БУКЭП, 2014. $-67 \mathrm{c}$.

204. Максименко С.В. Туристская деятельность: международноправовые аспекты / С.В. Максименко - Одесса: Латстар, 2001. - 168 с.

205. Манько Н.П. Отдельные подходы по обеспечению безопасности туристов в ходе путешествия / Н.П. Манько, Н.Н. Староверкина // Международный туризм и спорт: Материалы I Всероссийской научно- 
практической конференции с международным участием. Под редакцией Ю.В. Жилковой, 3.В. Макаренко; составитель: И.Е. Евграфов. - Москва, 21-22 ноября 2013 года. - С. 185-189.

206. Мартьянова Е.Г. Гастрономический туризм как перспективное направление культурно-познавательного туризма Тульского региона / Е.Г. Мартьянова, Е.Н. Чеснова // Гуманитарное и социально-научное знание: теоретические исследования и практические разработки: Сборник научных трудов по материалам Международной научно-практической конференции. Нижний Новгород, 10 декабря 2019 года. - С. 240-248.

207. Маслак Д.В. Пеший туризм в России / Д.В. Маслак //NovaInfo.Ru. 2017. - Т. 1. - № 67. - С. 337-340.

208. Маслов Е.С. Винный туризм как составная часть гастрономического направления в туризме / Е.С. Маслов // Экономический базис развития науки и технологий в России: Сборник трудов Международной научной конференции. Симферополь, 19-20 октября 2018 года. - С. 276-278.

209. Маслов Е.С. Возможности развития винного туризма и гостиничного комплекса / Е.С. Маслов // Ученые записки ТНУ им. В.И. Вернадского. - 2007. - Т. 20 (59). - № 3. - С. 102-107.

210. Махов С.Ю. Развитие активного туризма в Орловской области / С.Ю. Махов // Интеграция туризма в экономическую систему региона: перспективы и барьеры: материалы I международной научно-практической конференции. 2019. - С. 283-289.

211. Махова Н.С. Горный туризм в России / Н.С. Махова // Наука-2020. 2017. - № 1 (12). - С. 51-56.

212. Махова Н.С. Особенности активного туризма на Кольском полуострове / Н.С. Махова, С.Ю. Махов //Наука-2020. 2016. - № 4 (10). C. 255-262.

213. Махова Н.С. Развитие активного туризма в Архызе / Н.С. Махова // Наука-2020. 2016. - № 5 (11). - С. 343-348.

214. Мацарин А.С Круизный туризм в контексте стратегии развития туризма в РФ на период до 2035 г. / А.С. Мацарин // Актуальные проблемы развития сферы услуг: Сборник научных трудов. Под редакцией Ю.В. Долматеня, В.А. Ткачева. - Санкт-Петербург, 2019. - С. 211-215.

215. Мачалкин С.Е. Анализ динамики основных статистических показателей туристской отрасли в России / С.Е. Мачалкин, С.Н. Морева // 
Социально-экономические явления и процессы. 2018. - Т. 13. - № 104. - С. $130-134$.

216. Мачалкин С.Е. Современное состояние занятости молодежи в туристской отрасли / С.Е. Мачалкин, С.Н. Морева, А.Ю. Шевяков //Вестник Северо-Кавказского федерального университета. 2019. - № 6 (75). - С. 145-150.

217. Международный туризм: Правовые акты / сост. Н.И. Волошин, М.В. Михайлов; Российская международная академия туризма. - М.: Логос, 2014. -575 c.

218. Мельников В.В. Проблемы охотничьего туризма / В.В. Мельников, В.К. Мельников, Е.Ж. Кентбаев // Климат, экология, сельское хозяйство Евразии: материалы III международной научно-практической конференции, посвященной 80-летию образования ИрГСХА. - Иркутск, 29-31 мая 2014 года. - C. 227-236.

219. Мельникова Е.Е. Геоэкологические особенности развития научного туризма в Алтайском регионе / Е.Е. Мельникова //Современные научные исследования и разработки. 2017. - № 2 (10). - С. 350-351.

220. Микитюк К.В. Пешеходные и велосипедные маршруты, как фактор развития туризма в Коми-Пермяцком округе Пермского края / К.В. Микитюк /География и туризм. 2019. - № 1. - С. 168-171.

221. Микитюк К.В. Пешеходные и велосипедные маршруты, как фактор развития туризма в Коми-Пермяцком округе Пермского края / К.В. Микитюк // Географическое изучение территориальных систем: Сборник материалов XIII Всероссийской научно-практической конференции студентов, аспирантов и молодых учёных. Под редакцией М.Б. Ивановой. Пермь, 16-17 мая 2019 года. C. 244-248.

222. Мирошниченко П.Н. Туризм и устойчивое развитие горных территорий: история и современные проблемы / П.Н. Мирошниченко // Известия Чеченского государственного университета. 2019. - № 1 (13). C. $73-77$.

223. Митюнова И.Г. К вопросу о целесообразности создания туристической полиции в России / И.Г. Митюнова // Общественная безопасность, законность и правопорядок в ІІІ тысячелетии. 2018. - № 4-1. - С. 269-300.

224. Михин А.Э. Промышленный туризм в России: сущность, проблемы и перспективы развития / Михин А.Э. // Университетский комплекс как 
региональный центр образования, науки и культуры: Материалы Всероссийской научно-методической конференции (с международным участием). - Оренбург, 23-25 января 2020 года. - С. 944-947.

225. Моисеенко Д.Д. Роль туристской отрасли в экономике РФ и факторы ее формирования / Д.Д. Моисеенко // Экономика и современный менеджмент: теория и практика: Материалы международной научнопрактической конференции. В 2-х частях. Под общей редакцией В.Н. Узунова. - Симферополь, 13 апреля 2017 года. - С. 89-95.

226. Монахова Г.Н. Охотничий туризм - новая реальность экономики Урала (на примере Свердловской области) / Г.Н. Монахова // Гуманитарные аспекты охоты и охотничьего хозяйства. 2019. - № 1 (13). - С. 23-27.

227. Монтилья Л.В. Создание "туристической" полиции в Российской Федерации / Л.В. Монтилья // Правоохранительная и правозащитная деятельность: вчера, сегодня, завтра: сборник статей Международной научнопрактической конференции. Российский университет дружбы народов. Москва, 16 ноября 2018 года. - С. 114-116.

228. Морозов М.А. Конкурентоспособность туристской дестинации, анализ ее основных конкурентных преимуществ / М.А. Морозов // Современная конкуренция. 2013. - № 3 (39). - С. 23-29.

229. Мулик Е.В. Мотивация школьников и студентов к занятиям спортивно-оздоровительным туризмом / Е.В. Мулик, В.В. Мулик // Педагогика, психология и медико-биологические проблемы физического воспитания и спорта. 2015. - № 7. - С. 33-38.

230. Муртазина Г.Р. К вопросу безопасности в автобусном туризме / Г.Р. Муртазина // Вестник НЦБЖД. 2014. - № 1 (19). - С. 40-44.

231. Мякишева С.Н. Нормативно-правовые основы организации охотничьего туризма, лицензирование и сертификация охотничьего туризма / С.Н. Мякишева, М.В. Ульянова, Т.А. Толочко // Экологическое образование и природопользование в инновационном развитии региона: Сборник статей по материалам межрегиональной научно-практической конференции школьников, студентов, аспирантов и молодых ученых. - Красноярск, 19 февраля 2014 года. - С. 75-78.

232. Н.А. Цветкова Туризм и туристический сервис как показатели уровня и качества жизни россиян / Цветкова Н.А. // Социально-экономическое развитие регионов России: реалии современности, тенденции, перспективы 
(посвящается 70-летию колледжа Западного филиала РАНХиГС): материалы I Международной научно-практической конференции. - Калининград, 05-09 июля 2016 года. - С. 180-184.

233. Науменко Б.В. Совершенствование системы страхования в сфере туризма в Российской Федерации / Б.В. Науменко //Финансовая экономика. 2019. - № 3. - С. 381-385.

234. Нерукова М.В. Скалолазание, альпинизм как экстремальный вид туризма / М.В. Нерукова //Научный вестник МГИИТ. 2017. - № 1 (45). - С. 37-40.

235. Николаева О.К. Пеший туризм как уникальный общедоступный вид спортивного туризма / О.К. Николаева, А.Е. Тарасов //Инновационная наука. 2015. - № 11-2. - С. 251-253.

236. Норкулова Д.3. Роль диверсификации в развитии туризма в Узбекистане / Д.З. Норкулова, У.Э. Бойназаров //Индустрия туризма: возможности, приоритеты, проблемы и перспективы. 2018. - Т. 13. - № S. - C. 93-98.

237. Овсянникова С.А. Экологический туризм как одно из направлений въездного туризма в республике Алтай / С.А. Овсянникова // Сборник научных трудов: В 2 частях. - Горно-Алтайск, 2015. - С. 146-148.

238. Ожева С.Б. Мониторинг уровня развития велосипедного туризма как фактора здорового образа жизни в республике Адыгея / С.Б. Ожева, H.M. Суетина //Интегрированные коммуникации в спорте и туризме: образование, тенденции, международный опыт. 2017. - Т. 1. - С. 175-179.

239. Ожигов Ю.С. История развития лыжного спорта и туризма в Республике Бурятия / Ю.С. Ожигов, И.И. Старкова // Актуальные проблемы физической культуры, спорта и туризма: материалы XII Международной научно-практической конференции. - Уфа, 22-24 марта 2018 года. - С. 37-40.

240. Организация и проведение туристских походов в образовательных учреждениях: Учебно-методическое пособие / А.В. Абаев, В.В. Фарбей, В.В. Филиппов, Г.Г. Скорохватова, Е.Ю. Кизиляева, А.В. Борисевич. Под ред. В.В. Фарбея - СПб, изд-во "Печатный элемент", 2018. - 143 с.

241. Оришев А.Б. Клязьма как объект рыболовного туризма / А.Б. Оришев // День работников сельского хозяйства и перерабатывающей промышленности. - Москва, 14-15 октября 2019 года. - С. 109-113.

242. Орлова В.С. Водный экскурсионный туризм: проблемы и перспективы развития / В.С. Орлова //Экономика и социум. 2016. - № 5-2 (24). - C. 406-409. 
243. Осипова О.Я. Транспортное обслуживание туристов: учеб. пособие / О.Я. Осипова. - М.: Академия, 2007. - 368 с.

244. Памятка для туристов, пользующихся услугами туристических компаний //Туризм: право и экономика. 2014. - № 3. - С. 29-32.

245. Пергат А.П. Винный туризм Украины как составляющая винных туров Европы / А.П. Пергат // Культура народов Причерноморья. - 2013. № 248. - С. $85-89$.

246. Пиоль М. Астрономический туризм как одна из инноваций отрасли // М. Пиоль //Актуальные проблемы экономики, социологии и права. 2016. № 4. - C. 40-42.

247. Писаревский Е. Л. Антикриминальная безопасность туристов / Е.А. Писаревский // Право и безопасность. 2010. - № 40. - С. 44-47.

248. Писаревский Е.Л. Предложения Федерального агентства по туризму к Концепции проекта Федерального закона «О туризме и туристской деятельности в Российской Федерации» / Е.Л. Писаревский // Туризм: право и экономика. 2013. - № 2. - С. 28-32.

249. Писаревский Е.Л. Туризм и обеспечение его безопасности: административно-правовой аспект: монография / Е.Л. Писаревский. - М.: Юрист, 2011. - 496 с. // СПС «Консультант-Плюс».

250. Плещенко В.И. Использование потенциала промышленного туризма металлургическими предприятиями современной России / В.И. Плещенко //Экономика в промышленности. 2020. - Т. 13. - № 2. - С. 218224.

251. Показатели сформированности компетенции безопасности туристской деятельности в подготовке бакалавров физической культуры / М.А. Возисова, Т.Н. Шутова, П.А. Кондратьев, А.Г. Ростеванов // Культура физическая и здоровье. 2018. - № 1 (65). - С. 103-106.

252. Поколодная М.Н. Организационные особенности охотничьерыболовного туризма / М.Н. Поколодная // Международный научный журнал Интернаука. 2016. - № 12-2 (22). - С. 127-129.

253. Ползикова М.А. Новое направление научно-познавательного туризма: астрономический туризм / М.А. Ползикова, Г.Н. Кутепова // Индустрия туризма: возможности, приоритеты, проблемы и перспективы. 2019. - Т. 14. - № 1. - С. 108-114.

254. Понедельник А.А. Инвестиции в сферу гостеприимства как предпосылка будущей успешности регионов России в качестве международных 
туристских дестинаций / А.А. Понедельник, Н.В. Соковнина, Д.А. Рубан // Вестник НГУЭУ. 2017. - № 2. - С. 174-192.

255. Понедельник А.А. Пространственная дифференциация стоимости размещения в российских гостиницах / А.А. Понедельник, Д.А. Рубан //Новые технологии. 2016. - № 4. - С. 50-54.

256. Пономарева М.В. Особенности гастрономического туризма в Тульской области / М.В. Пономарева, А.А. Комкова // Международное приграничное сотрудничество и туристический потенциал к событиям мирового уровня: Сборник статей II Международной научно-практической конференции. Редколлегия: Н.В. Полянскова (отв. ред.) [и др.]. - Самара, 19 апреля 2017 года. - С. 61-67.

257. Попов А.Д. От "Школы мужества" к источнику здоровья и радости: эволюция лыжного туризма в СССР / А.Д. Попов //Вестник Московского государственного областного университета. Серия: История и политические науки. 2019. - № 2. - С. 160-170.

258. Поспелова С.В. Характеристика туристского потенциала автобусного туризма и новые возможности в связи с вводом в эксплуатацию крымского моста / С.В. Поспелова / Развитие методологии современной экономической науки и менеджмента: Материалы II Междисциплинарной Всероссийской научно-практической конференции. Научный редактор Т.А. Кокодей, ответственный редактор Т.И. Ломаченко. - Севастополь, 07-08 мая 2018 года. - С. 185-193.

259. Потапова К.К. Влияние туризма на социально-экономическое развитие регионов / К.К. Потапова // Молодой ученый. 2016. - №24. - С. 219222 .

260. Правовое обеспечение туризма: учебник / коллектив авторов; под общ. ред. Е.Л. Писаревского. - М.: Федеральное агентство по туризму, 2014. $336 \mathrm{c}$.

261. Припотень В.Ю. Оценка приоритетных объектов промышленного туризма / В.Ю. Припотень, Н.Н. Шиков //Менеджер. 2017. -№2 (80). - С. 33-39.

262. Пробин П.С. Проблемы и перспективы развития внутреннего туризма в России (на примере рыболовного и охотничьего туризма) / П.С. Пробин // Региональные аспекты функционирования гостиничной индустрии $=$ regional aspects of the hospitality industry: материалы II Всероссийского научно-практического семинара = Materials II Russian 
scientific-practical seminar. Под редакцией: О.Ю. Колосовой, Т.В. Вергун, Ю.С. Авраменко. - Ставрополь, 05 декабря 2014 года. - С. 188-190.

263. Промышленный туризм как инструмент развития туризма в моногородах / С.А. Волков, А.С. Аджарян, Е.В. Малюженко, А.А. Кабаргина, И.И. Гуторов //Экономика и предпринимательство. 2019. - № 10 (111). - С. 445 448.

264. Пугиев В.Г. Массовый туризм - путь оздоровления нации / В.Г. Пугиев // Вестник РМАТ. 2011. - №3. - С. 3-9.

265. Пштыка В.В. Перспективы развития водного туризма в Калининградской области / В.В. Пштыка //Регион сотрудничества. 2009. - № 2. - C. 53-58.

266. Развитие нравственных и физических качеств студенческой молодежи средствами лыжного туризма / В.И. Курилова, С. Редько, С. Пильтяй, Н. Пилипенко, В. Павленко //Актуальные научные исследования в современном мире. 2020. - № 6-5 (62). - С. 111-114.

267. Ремпель О.В. Гарантии безопасности туристов в условиях банкротства туроператоров / О.В. Ремпель // Современное состояние и потенциал развития туризма в России: сборник статей XI Международной научно-практической конференции. под общей редакцией Д.П. Маевского. Омск, 26-27 ноября 2014 года. - С. 132-134.

268. Роль пешего туризма во всестороннем развития студенческой молодежи / В.И. Курилова, Г.А. Бутенко, С.Ю. Редько, С.В. Белый // Актуальные научные исследования в современном мире. 2020. - № 6-5 (62). C. 87-93.

269. Романчук О.Н. Экологический туризм на особо охраняемых природных территориях / О.Н. Романчук, А.П. Суворов // Вестник КрасГАУ 2015. - № 5. - С. 36-39.

270. Рубис Л.Г. Туризм и основы безопасности в спортивном туризме / Л.Г. Рубис // Вестник Санкт-Петербургского государственного университета технологии и дизайна: серия 3: Экономические, гуманитарные и общественные науки. - 2013. - № 4. - С. 68-74.

271. Русанов И.В. Винный туризм в Крыму. / И.В Русанов. Севастополь: Библекс, 2008. - 216 с.

272. Рыцев А.И. Промышленный туризм в контексте социальноориентированного управления: передовой опыт / А.И. Рыцев //Экономика и социум. 2014. - № 4-6 (13). - С. 913-915. 
273. Сапронов Ю.Г. Безопасность жизнедеятельности. Обеспечение безопасности в туризме и туристской индустрии: учебное пособие / Сапронов Ю.Г., Занина И.А., Соколовская О.В. - Ростов-на-Дону, Издательство: Феникс. 2009. - 277 с. Сер. Серия "Высшее образование.

274. Сафронова П.А. Влияние сезонности на туристический поток в Республике Алтай / П.А. Сафронова // Развитие социально-культурной деятельности и художественного образования: теория и практика: материалы VIII межрегиональной (с международным участием) научно-практической конференции (Барнаул, 9-20 апреля, 22 октября 2020 г.). Алтайский государственный институт культуры. - Барнаул, 09 апреля - 222020 года. C. 236-239.

275. Селиванов В.В. Возрождение традиций горного туризма республики Крым как важного элемента интеграции музейного дела и туризма / В.В. Селиванов // Экономика. Менеджмент. Сервис. Туризм. Культура (ЭМСТК-2019). Сборник статей XXI Международной научно-практической конференции. Барнаул, 23 мая 2019 года. - С. 77-84.

276. Селиванова А.В. Конный туризм, как вид активного отдыха и спортивного туризма / Селиванова А.В. // Актуальные проблемы физического воспитания студентов: Материалы Международной научно-практической конференции. - Чебоксары, 30-31 января 2019 года. - С. 239-242.

277. Семенихин В.В. Игорный бизнес. Лотереи. Лицензирование. Бухгалтерский и налоговый учет / В.В. Семенихин. - М.: Эксмо, 2005. - 128 с.

278. Сенин В.С. Организация международного туризма / В.С. Сенин. М.: Финансы и статистика, 2008. - 200 с.

279. Сергеева Т.Л. Экологический туризм: Учебник / Т.Л. Сергеева. М.: Финансы и статистика, 2004. - 360 с.

280. Сиднева С.И. О диверсификации рекреационных услуг организаций сферы отдыха и туризма на примере локальной / С.И. Сиднева, Н.И. Асташина // Орфановские чтения - 2020. сборник статей по материалам Всероссийской научно-практической конференции. Нижегородский государственный педагогический университет им. К. Минина. 2021. - Нижний Новгород, 17 декабря 2020 года. - С. 122-126.

281. Сидоренко С.М. Безопасность жизнедеятельности. Человеческий фактор в обеспечении безопасности : учебное пособие для студентов высших учебных заведений / С.М. Сидоренко - Краснодар: Издательство: ФГОУ ВПО 
Кубанский гос. аграрный ун-т, 2009. - 159 с.

282. Симакова Е.И. Современное состояние и тенденции развития автобусного туризма в России / Е.И. Симакова // Междисциплинарная интеграция как двигатель научного прогресса: сборник материалов Международной научно практической конференции. - Новосибирск, 05 июня 2020 года. - С. 436-440.

283. Сирик Н.В. Страхование от невыезда в сфере туризма: проблемы правоприменения / Н.В. Сирик, А.С. Кусков //Хозяйство и право. 2019.№ 10 (513). - С. 62-69.

284. Сирик Н.В. Договор оказания туристских услуг в гражданском праве России: автореф. дис. канд. юрид. наук /Н.В. Сирик - М., $2001-22$ с.

285. Скибина В.А. Общее оздоровление организма посредством занятия спортивным туризмом / В.А. Скибина, Л.М. Демьянова, Н.А. Дьяконова // Научный электронный журнал Меридиан. 2020. - № 9 (43). - С. 496-498.

286. Соловьянова М.В. Современное состояние и перспективы развития международного автобусного туризма / М.В. Соловьянова, Ю.Д. Сиделева // Туристический, гостиничный и ресторанный бизнес: инновации и тренды: материалы региональной научно-практической конференции. - Курск, 26 апреля 2019 года. - С. 123-128.

287. Срибная Т.А. Потенциал Астраханской области в контексте развития организованного рыболовного туризма / Т.А. Срибная, Н.А. Боднева // Научное обозрение. Серия 1: Экономика и право. 2020. - № 1-2. - С. 224-234.

288. Старкова И.И. Водный туризм как одно из направлений в рекреации / И.И. Старкова, Е.А. Крыласова, Л.Г. Доржиева // Вестник Бурятского государственного университета. Экономика и менеджмент. 2020. - № 2. C. $34-40$.

289. Стригулина А.В. Взаимодействие России с региональными интеграционными объединениями по вопросам правового регулирования отношений в сфере туризма / А.В. Стригулина // Журнал российского права. 2007. - №7. - С. 89-102.

290. Струзберг Г.В. Современное состояние и перспективы развития промышленного туризма / Г.В. Струзберг //Инфраструктурные отрасли экономики: проблемы и перспективы развития. 2013. - № 3. - С. 147-151.

291. Суданова С. Развитие водного туризма / С. Суданова // Актуальные проблемы и перспективы инновационного развития туризма, сервиса и сферы 
услуг: Сборник трудов XVI Международной заочной научно-практической конференции. Редакторы: Огнева С.В., Шемятихина Л.Ю. - Москва, 17 марта 2015 года. - С. 194-197.

292. Сухолитко А.С. Винный туризм как способ повышения конкурентоспособности предприятия и отрасли в целом / Сухолитко А.С., Абрамова Л.С. //Вектор экономики. 2018. № 12 (30). С. 172.

293. Таскаев Н.А. Образовательная программа "обеспечение безопасности жизнедеятельности в активном пешем туризме" / Н.А. Таскаев // Физическая культура, спорт, туризм: научно-методическое сопровождение: материалы Всероссийской научно-практической конференции с международным участием. - Пермь, 19-21 мая 2016 года. - С. 226-331.

294. Темирчиева Д.Ф. Вопросы безопасности в туризме Д.Ф. Темирчиева // Аллея науки.2019. - №6. - С. 124-127.

295. Теория организации промышленного туризма / А.И. Ярембаш, Я.Н. Хомутовская, А.Н. Кузьминов, В.А. Артеменко, В.Ю. Припотень //Экономика. Менеджмент. Инновации. 2018. - № 3 (15). - С. 75-77.

296. Тесленко В.В. Трансформация гостиничных услуг под новые виды туризма на примере эко-отелей и экологического туризма / В.В. Тесленко, Е.В. Романова //Здоровье человека, теория и методика физической культуры и спорта. 2019. - № 4 (15). - С. 414-419.

297. Тимерханова Э.И. Природные парки в системе экологического туризма / Э.И Тимерханова. // Организация территории: статика, динамика, управление. XVII Всероссийская научно-практическая конференция с международным участием, посвященная 175-летнему юбилею Русского географического общества. - Уфа, 27 ноября 2020 года. - С. 156-159.

298. Тихонова Н.В. Перспективы развития рынка однодневного автобусного туризма на Южном Урале / Н.В. Тихонова, А.Э. Скороходова // Сервис: экономика, техника, образование: межвузовский сборник научных трудов. Министерство образования и науки Российской Федерации ЮжноУральский государственный университет Кафедра экономики и управления на предприятиях сферы услуг, рекреации и туризма. - Челябинск, 2018. - С. 46-51.

299. Ткаченко Д.А. Перспективы развития рыболовного туризма в Ханты-Мансийске / Д.А. Ткаченко // Взгляд молодых ученых на современность: Материалы $\mathrm{V}$ Всероссийской научно-практической конференции с международным участием. - Ханты-Мансийск, 23 ноября 2018 года. - С. 384-386. 
300. Толкачева О.П. Особенности страхования в отрасли туризма / О.П. Толкачева, К.А. Джобинашвили // Вестник Санкт-Петербургского университета МВД России. - 2011. - № 3. - С.155-158.

301. Томилин К.Г.Яхтинг: молодежный спортивный и спортивнооздоровительный туризм / К.Г. Томилин // Молодежный спортивный и спортивно-оздоровительный туризм: современное состояние и перспективы развития: материалы Всерос. науч.-практ. конф., г. Сочи, 17-20 мая 2016 г. Сочи: Изд-во РИЦ «СГУ», 2016. - С. 65-69.

302. Томилин К.Г. Парусный туризм: проблемы повышения конкурентоспособности Азово-Черноморского курортного региона России / К.Г. Томилин //Вестник ИМСИТ. 2015. - № 1 (61). - С. 68.

303. Тортумашева Я.В. Развитие летнего туризма в Горной Шории / Я.В. Тортумашева // Актуальные вопросы истории, социально-политических наук и туризма. Материалы симпозиума в рамках XV (XLVII) Международной научной конференции студентов, аспирантов и молодых ученых. Под научной редакцией О.О. Шишкиной. - Кемерово, 01-30 апреля 2020 года. - С. 246-250.

304. Тургинбаева А.Н. Гостиничный бизнес как системообразующая часть делового туризма в Казахстане / А.Н. Тургинбаева, Г.Е. Жакупбекова // Экономические и гуманитарные науки. 2020. - № 5 (340). - С. 94-102.

305. Турдумамбетов Б.У. Этика международного охотничьего туризма / Б.У. Турдумамбетов //Вестник Национальной академии туризма. 2019.№ 2 (50). - С. 46-47.

306. Туризм и экономический рост: региональный аспект / Е.А. Федорова, Л.И. Черникова, А.Э. Пастухова, Л.К. Ширяева //ЭКО. 2020.№ 9 (555). - С. 138-155.

307. Успенский А.А. Влияние занятий горным туризмом на сохранение и укрепление здоровья студентов / А.А. Успенский, Н.В. Савкина //Наука-2020. 2019. - № 7 (32). - С. 127-130.

308. Усыскин Г. Очерки истории российского туризма / Г. Усыскин. Санкт-Петербург: Герда, 2000. - 224 с.

309. Фафикова А.Е. Анализ развитие водного вида туризма в РФ / А.Е. Фафикова // Инновационное развитие сферы туризма: Сборник трудов Международной научно-практической конференции. - Москва, 15-17 ноября 2016 года. - С. 291-296. 
310. Федеральный закон от 24.11.1996 № 132-Ф3 «Об основах туристской деятельности в Российской Федерации» (с изм. и доп., вступ. в силу с 01.01.2018) // Собрание законодательства РФ. - 1996. - № 49. -Ст. 5491

311. Федорко П.Д. Пеший туризм как цель занятий физической культурой в вузах / П.Д. Федорко, И.А. Сухорукова //Актуальные проблемы физической культуры и спорта в системе высшего образования: Сборник материалов III международной научно-практической конференции. - Омск, 24 января 2020 года. 2020. - С. 75-78.

312. Федорченко Н.И. Использование игровых технологий в туристскокраеведческой работе / Н.И. Федорченко, С.Н. Рябых // Вестник Академии детско-юношеского туризма и краеведения. 2014. - № 3 (112). - С. 157-164.

313. Федотов Ю.Н. Спортивно-оздоровительный туризм Ю.Н. Федотов, И.Е. Востоков; под ред. В.А. Таймазова, Ю.Н. Федотова. - М.: Сов. спорт, 2008. -464 с.

314. Федотов Ю.Н. Спортивно-оздоровительный туризм: учебник для студентов вузов / Ю.Н. Федотов, И.Е. Востоков; [под ред. Ю.Н. Федотова]. [2-е изд., стер.]. - М.: Советский спорт, 2004. - 328 с.

315. Фиклисова О.А. Богатое наследие России и низкие доходы от туризма: причина и следствие / О.А. Фиклисова / Современные тенденции в экономике и управлении: новый взгляд. 2012. - № 17. - С. 310-315.

316. Филипова В.Н. Особенности промышленного туризма / В.Н. Филипова // Вестник Воронежского института высоких технологий. 2011. - № 8. - С. 138-139.

317. Финансовые поступления от международного туризма в России: сравнительный анализ, проблемы, пути их решения / Н.Н. Яшалова, О.А. Зубрилина, А.А. Понедельник, Н.А. Латушко, Д.А. Рубан //Вестник УрФУ. Серия: Экономика и управление. 2018. - Т. 17. - № 2. - С. 200-223.

318. Формирование компетенций безопасности туристской деятельности в подготовке будущих бакалавров физической культуры / М.А. Возисова, Т.Н. Шутова, Е.О. Рыбакова, А.В. Шаравьева // Физическая культура: воспитание, образование, тренировка. 2018. - № 3. - С. 32-33.

319. Фурзикова М.А. Вопросы комплексной автоматизации технологического обеспечения автобусного туризма / М.А. Фурзикова, М.Г. Петухова // Молодой исследователь: от идеи к проекту: Материалы IV студенческой научно-практической конференции. - Йошкар-Ола, 2020. - С. 382-384. 
320. Халапурдина В.В. К вопросу о развитии винного туризма в мире на современном этапе / В.В. Халапурдина //Ученые записки Крымского федерального университета имени В.И Вернадского. География. Геология. 2018. - T. 4 (70). - № 3. - C. 80-85.

321. Халапурдина В.В. К вопросу о сущности понятия "винный туризм" / В.В. Халапурдина //Вестник Луганского национального университета имени Тараса Шевченко. 2018. - № 3 (19). - С. 88-93.

322. Харитонова Т.В. Оценка конкурентоспособности россии как единой туристской дестинации (на основе зарубежной методики) / Т.В. Харитонова, О.И. Вапнярская, О.М. Голикова //Сервис в России и за рубежом. 2014.№ 6 (53). - С. 119-139.

323. Хасянова А.Р. Водный туризм в Тверской области / А.Р. Хасянова // Актуальные проблемы и перспективы инновационного развития туризма, сервиса и сферы услуг: Сборник трудов XVI Международной заочной научнопрактической конференции. Редакторы: Огнева С.В., Шемятихина Л.Ю. Москва, 17 марта 2015 года. - С. 162-165.

324. Хлевная Т.И. Ресурсный потенциал рыболовного туризма в Сахалинской области / Т.И. Хлевная, Л.Х. Назарова //Вестник Национальной академии туризма. 2020. - № 2 (54). - С. 62-64.

325. Цветков Е.И. Проблемы и особенности организации автобусных туров в выездном туризме / Е.И. Цветков //Проблемы и перспективы развития транспортного обеспечения в туризме. 2015. - № 3. - С. 111-120.

326. Циперсон Э.Х. Испытание снегами. О безопасности в лыжном туризме / Э.Х. Циперсон //Вестник Академии детско-юношеского туризма и краеведения. 2014. - № 1 (110). - С. 114-136.

327. Чеботарева И.А. Сотрудничество государств по правовому регулированию международной туристской деятельности: Автореф. ... канд. юрид. наук / И.А. Чеботарева - СПб, 2004. - 22 с.

328. Чекмарева Н. Спортивно-оздоровительный туризм и рекреационно-оздоровительная деятельность современной молодежи / Н. Чекмарева, В. Хаджинов, А. Максимов, М. Присяжная //Актуальные научные исследования в современном мире. 2019. - № 9-2 (53). - С. 56-60.

329. Чененов Ю.А. Гражданско-правовое регулирование туристской деятельности: автореф. дис.. канд. юрид. наук /Ю.А. Чененов. - Екатеринбург, $2003-22$ c. 
330. Черкасов В.В. Использование туризма в качестве средства оздоровления детей и подростков / В.В. Черкасов, К.А. Тартаимова // Региональный туризм: проблемы и перспективы развития. Материалы II Всероссийской научно-практической конференции. - Тобольск, 2015. -С. 211-213.

331. Черняк А.Ю. Кластерное развитие яхтенного туризма в республике Крым / А.Ю. Черняк // Ученые записки Крымского федерального университета имени В.И. Вернадского. Экономика и управление. - 2018. - Т. 4(70). - № 1. C. $132-139$.

332. Чудновский А.Д. Управление индустрией туризма А.Д. Чудновский, М.А. Жукова, В.С. Сенин - М.: КНОРУС, 2004. - С. 7.

333. Чэнь Сю. Перспективы развития автобусного туризма / Сю Чэнь // Современные проблемы экономической науки: Сборник статей. Редколлегия: В.Я. Андрухова, О.В. Архипкин. - Иркутск, 2017. - С. 279-282.

334. Шеманаев В.К. Экстремальный туризм и экстремальность в туризме / В.К. Шеманаев //Вестник Балтийской педагогической академии. 2008. - № 82. - C. 336-342.

335. Шепель А.А. Характеристика перспектив развития спортивного и экстремального туризма в России и странах СНГ / А.А. Шепель // Актуальные проблемы и пути инновационного развития: Материалы $\mathrm{X}$ международной научно-практической конференции. - Москва, 16-17 февраля 2016 года. - С. $106-111$.

336. Шишкин В.В. Обеспечение безопасности туристов на спортивномассовых мероприятиях / В.В. Шишкин //Научные труды Сибирского государственного университета физической культуры и спорта. 2018. - Т. 1. C. $77-80$.

337. Школьная Л.И. Рыболовный туризм как резерв устойчивого развития сельских территорий в Орловской области / Л.И. Школьная, В.А. Зуенко // Новейшие генетические технологии для аквакультуры: Материалы Всероссийской научно-практической конференции с международным участием. Электронное издание. - Москва, 29-31 января 2020 года. - С. 446-452.

338. Шольц-Куликов Е.П. Маршруты винного туризма в Крыму / Е.П. Шольц-Куликов // Крымские каникулы. - 2011. - №1 (12). - С. 48-50.

339. Шоричева А.Ю. Развитие охотничьего туризма на территории Омского региона / А.Ю. Шоричева // Материалы всероссийской научнопрактической конференции. - Омск: Ом ГУПС, 2013. - 255 с. 
340. Шоричева А.Ю. Организационно-правовые аспекты охотничьего туризма / А.Ю. Шоричева // Современное состояние и потенциал развития туризма в России: сборник статей XI Международной научно-практической конференции. Под общей редакцией Д.П. Маевского. - Омск, 26-27 ноября 2014 года. - С. 94-95.

341. Шоричева А.Ю. Состояние и перспективы развития охотничьего туризма в Омской области / А.Ю. Шоричева // Современное состояние и потенциал развития туризма в России: сборник статей XI Международной научно-практической конференции. Под общей редакцией Д. П. Маевского. Омск, 26-27 ноября 2014 года. - С. 40-41.

342. Шмырев Д.А. Астротуризм как перспективное направление научнопознавательного туризма // Д.А. Шмырев //Современные проблемы гуманитарных и общественных наук. 2019. - № 1 (23). - С. 104-108.

343. Щербакова Н.В. Исследование актуальности пешего туризма / Н.В. Щербакова, Н.П. Богданова //Аллея науки. 2018. - Т. 2. - № 10 (26). - С. 273-277.

344. Экологический туризм как инновационное направление сокращения безработицы на селе / А.И. Фирсов, М.С. Юркова, Н.В. Уколова, Н.А. Новикова //Научное обозрение: теория и практика. 2017. - № 6. - С. 96-103.

345. Экологическое обеспечение водного туризма / В.И. Решняк, О.Л. Домнина, А.Е Пластинин., Н.С. Отделкин //Морские интеллектуальные технологии. 2019. - № 4-2 (46). - С. 154-160.

346. Эрбен А.С. К вопросу о развитии научного туризма на территории Крыма / А.С. Эрбен, В.В. Анисимова //International Journal of Student Research. 2019. - № 4 (5). - C. 11-24.

347. Юдина Е.Ю. Велосипедные путешествия как вид внутреннего туризма в России начала XX столетия / Е.Ю. Юдина // Фундаментальные и прикладные исследования физической культуры, спорта, олимпизма: традиции и инновации: материалы I Всероссийской научно-практической конференции. Москва, 24-25 мая 2017 года. - С. 184-190.

348. Яцык В.3. Велотуризм и его оздоровительное влияние / В.З. Яцык, Н.О. Букреева, Ю.Ю. Предко // Инновации в образовании, физической культуре, спорте и туризме: Материалы международной научно-практической конференции, посвященной 75-летию Победы в Великой Отечественной войне. - Алматы, 24 апреля 2020 года. - С. 277-279. 
349. Baldigara T. Modelling international tourism demand using seasonal arima models / T. Baldigara, M. Mamula //Tourism and Hospitality Management. 2015. Vol. 21. P. 1-31.

350. Cro S. Structural breaks in international tourism demand: Are they caused by crises or disasters? / S. Cro, A.M. Martins //Tourism Management. 2017. Vol. 63. P. 3-9.

351. Deng T. Has international tourism promoted economic growth in China? A panel threshold regression approach / T. Deng, M. Ma, S. Shao //Tourism Economics. 2014. Vol. 20. P. 911-917.

352. Dogru T. Remodeling international tourism demand: Old theory and new evidence / T. Dogru, E. Sirakaya-Turk, G.I. Crouch //Tourism Management. 2017. Vol. 60. P. 47-55

353. Edgell D.L. International tourism policy / D. L. Edgell // Van Nostrand Reinhold. - 1990. - 204 p.

354. Iastremska O. Definition of tourist companies attractiveness in international tourism / O. Iastremska //Economic Annals-XXI. 2014. Vol. 11-12. P. 124-127.

355. Peng B. Ameta-analysis of international tourism demand forecasting and implications for practice / B. Peng, H. Song, G.I. Crouch // Tourism Management. 2014. Vol. 45. P. 181-193.

(C) В.Н. Прокопьев 


\title{
ГЛАВА IV. \\ СОСТОЯНИЕ И ПЕРСПЕКТИВЫ РАЗВИТИЯ СОВРЕМЕННОГО СЕЛЬСКОГО ХОЗЯЙСТВА
}

\author{
УДК 634.11 : [631.558.1 + 631.243.5 + 663.813]
}

\section{УБОРКА УРОЖАЯ, ХРАНЕНИЕ И ПЕРЕРАБОТКА ПЛОДОВ ЯБЛОНИ}

\author{
Дулов Михаил Иванович \\ доктор сельскохозяйственных наук, профессор, \\ заведующий научно-исследовательским отделом, \\ ведущий научный сотрудник \\ Научно-исследовательский институт садоводства \\ и лекарственных растений «Жигулевские сады» (г. Самара)
}

\begin{abstract}
Аннотация: Плоды яблони незаменимы в питании человека, так как повышают иммунитет, положительно влияют на стрессоустойчивость, содержат много полезных питательных и биологически активных природных веществ антиоксидантного действия. В России плодов яблони на одного человека производится в четыре раза меньше, чем требуется по рациональным нормам потребления пищевых продуктов, отвечающих современным требованиям здорового питания. Увеличение объемов отечественного производства яблок во многом зависит от возделывания в каждой почвенноклиматической зоне адаптированных высокоурожайных сортов с хорошим качеством плодов, подбора оптимальных сроков их съема, способов и режимов хранения, обеспечивающих минимальные потери количества и качества продукции. Это позволит иметь в стране не только большее количество плодов для употребления в свежем виде, но и для использования их в качестве сырья при производстве продуктов здорового питания.

Ключевые слова: яблоня, сорт, сроки зрелости плодов, биохимический состав, уборка урожая, хранение, переработка.
\end{abstract}


HARVESTING, STORAGE AND PROCESSING OF APPLE FRUITS

\section{Dulov Mikhail Ivanovich}

Abstract: Apple fruits are indispensable in human nutrition, as they increase immunity, have a positive effect on stress resistance, and contain many useful nutrients and biologically active natural substances of antioxidant action. In Russia, apple fruit is produced four times less per person than is required by the rational norms of food consumption that meet the modern requirements of a healthy diet. The increase in the volume of domestic production of apples largely depends on the cultivation of adapted high-yielding varieties with good fruit quality in each soil and climate zone, the selection of optimal terms for their removal, methods and storage modes that ensure minimal losses in the quantity and quality of products. This will allow the country not only to have more fruits for fresh consumption, but also to use them as raw materials in the production of healthy food products.

Key words: apple tree, variety, fruit maturity, biochemical composition, harvesting, storage, processing.

Яблоня является одной из наиболее экономически значимых культур и выращивается во всех умеренных зонах. Плоды яблони незаменимы в питании человека, так как содержат много полезных для человека питательных и биологически активных природных веществ антиоксидантного действия, повышающих устойчивость организма к неблагоприятным факторам внешней среды $[1,2]$.

Ежегодно в мире производится в среднем 89,56 млн. тонн яблок. Крупнейшим производителем яблок в мире является Китай, который производит их в среднем 44,45 млн. тонн или 49,6\% всего мирового производства. На втором месте по производству яблок Соединенные Штаты Америки (4,65 млн. тонн), на третьем Польша (3,60 млн. тонн), на четвертом Турция (2,93 млн. тонн), на пятом Индия (2,87 млн. тонн).

В России яблоня выращивается на площади 214,3 тыс. га и объем производства плодов составляет в среднем 1,84 млн. тонн или 12,6 кг на одного человека, что почти в 4 раза меньше, чем определено в стране Рекомендациями по рациональным нормам потребления пищевых продуктов, отвечающих современным требованиям здорового питания [3]. 
Химический состав и потребительские свойства свежих плодов яблони изменяются в процессе их созревания, во многом зависят от сорта, почвенноклиматических условий и агротехнических приёмов выращивания, сроков уборки, условий и продолжительности хранения $[4,5]$.

По срокам созревания яблоки условно подразделяют на яблоки ранних и поздних сроков созревания. Сбор урожая яблок ранних сроков созревания проводят до 1 сентября, поздних сроков созревания, соответственно, после 1 сентября.

В зависимости от сорта и условий выращивания свежие плоды яблони содержат 12,5-16,0\% сухих веществ, 11,5-14,5\% углеводов, 2,0-3,0\% клетчатки, 0,15-0,25\% минеральных веществ, 0,6-1,1\% пектиновых веществ (с высокой желирующей активностью) и до $1,2 \%$ различных кислот.

Углеводы в яблоках в основном представлены моно- и дисахаридами, их количество изменяется от 8,4 до 11,5\%. На долю глюкозы приходится 1,7-2,8\%, фруктозы 5,6-6,5\%, сахарозы 0,8-2,5\%. Из макроэлементов в яблоках содержится калий (80-320 мг\%), фосфор (9-23 мг\%), кальций (3-16 мг\%), кремний (2-5 мг\%), магний (3-9 мг\%), из микроэлементов - бор (210-240 мкг\%), алюминий (80-110 мкг\%), марганец (27-85 мкг\%), медь (8-65 мкг\%), цинк (35140 мкг\%).

Содержание витамина $\mathrm{B}_{1}$ (тиамин) в яблоках составляет $0,010-0,025 \mathrm{mг} \%$, витамина $\mathrm{B}_{2}$ (рибофлавин) - 0,007-0,015 мг\%, витамина $\mathrm{B}_{4}$ (холин) - 3,0-3,5 мг\%, витамина $\mathrm{B}_{5}$ (пантотеновая кислота) - 0,10 мг\%, витамина $\mathrm{B}_{6}$ (пиридоксин) - 0,030-0,085 мг\%, витамина В 9 (фолиевая кислота) - 4,5-17,5 мг\%, витамина С (аскорбиновая кислота) - 2,6-31,0 мг\%, витамина Е (альфатокоферол) $-0,45-0,65 \mathrm{Mг} \%$.

В яблоке и яблочной кожице содержатся такие антиоксидантные соединения как катехин, хлорогеновая кислота, эпикатехин, процианадин, кумаровая кислота, галловая кислота. В мякоти яблока катехина, эпикатехина, процианадина содержится меньше, чем в кожице. Хлорогеновой кислоты больше в мякоти, чем в кожице. Биологически активные вещества, присутствующие в яблоках и кожице, имеют значительный потенциал для улучшения здоровья человека, способствуют профилактике сердечнососудистых заболеваний, диабета, воспаления и онкологических заболеваний.

Качество плодов яблони для употребления в свежем виде регламентируется стандартом ГОСТ 34314-2017 «Яблоки свежие, реализуемые 
в розничной торговле. Технические условия» и подразделяется на высший, первый и второй товарные сорта [6]. Критериями оценки качества являются: внешний вид плодов, площадь окрашенной поверхности для определённой цветовой группы, дефекты форм, кожицы, механические повреждения, запах и вкус, степень зрелости и состояние плода, состояние мякоти, отсутствие признаков поражения болезнями и вредителями.

Яблоки свежие высшего товарного сорта должны быть целыми, чистыми, с типичной для помологического сорта формой и окраской, без постороннего запаха и привкуса. В период съёмной степени зрелости плоды должны выдерживать погрузку, транспортирование, разгрузку и доставку к месту назначения. Массовая доля (количество) плодов, не соответствующих по органолептическим показателям качества требованиям данного товарного сорта, не более 5,0\%. Полное отсутствие яблок, поврежденных вредителями, загнивших, гнилых, с признаками увядания, перезрелых, с побурением мякоти. Наибольший поперечный диаметр плода должен быть не менее 60 мм, масса плода - не менее 90 г.

Современные способы хранения плодов яблони предусматривают наличие хранилищ с искусственным охлаждением и регулируемой атмосферой, обеспечивающих поддержание в камере хранения заданных режимов температуры, влажности и состава газовой среды, а также применение ингибиторов этилена и антиоксидантов. При хранении яблок в регулируемой атмосфере при пониженных температурах потери снижаются в 2-3 раза, а сроки хранения удлиняются на 1,5-2 месяца [7, 8, 9].

На хранение закладывают плоды сортов осеннего и зимнего срока созревания. Лёжкость плодов при хранении во многом зависит от периода их съёма. Уборку урожая плодов осеннего срока созревания проводят с середины первой декады до конца сентября и в зависимости от сорта хранят их в течение 3-5 месяцев в специализированных хранилищах-холодильниках при влажности воздуха 90-92\% и температуре от 0 до $+3{ }^{0} \mathrm{C}$.

По состоянию на февраль 2021 года в Госреестр селекционных достижений включены и допущены для выращивания в Средневолжском регионе следующие сорта яблони осеннего срока созревания: Спартак (ос), Волжская красавица (ос), Коричневое полосатое (ос), Орловское полосатое (ос), Осеннее полосатое (oc), Теньковская (ос), Жигулёвское (по), Самарский рубин (по), Память Кедрина (по). Характеристика плодов сортов яблони осеннего срока созревания, приведена в таблице 1. 
Плоды яблони сортов зимнего срока созревания - Утёс (рз), Антоновка обыкновенная (рз), Куйбышевское (зи), Кутузовец (зи), Северный синап (зи), Башкирский красавец (зи), Ветеран (зи), Звёздочка (зи), Зимнее полосатое (зи), Куликовское (зи), Мартовское (зи), Московское красное (зи), Пепин шафранный (зи), Ренет татарский (зи), Ренет Черненко (зи), Синап орловский (зи), Московское зимнее (пз) - начинают собирать с середины сентября до начала октября и, в зависимости от сорта, хранят при оптимальных режимах температуры $\left(0 \ldots+2^{0} \mathrm{C}\right)$, относительно влажности воздуха (90-92\%) и состава газовой среды в камере $\left(\mathrm{O}_{2}-2-3 \%, \mathrm{CO}_{2}-2-5 \%\right)$ до мая месяца. Характеристика плодов яблони сортов зимнего срока созревания, допущенных для выращивания в Средневолжском регионе, приведена в таблице 2.

Приведённые оптимальные сроки уборки урожая плодов яблони осеннего и зимнего срока созревания являются примерными и могут изменяться по времени с определёнными интервалами в зависимости от условий вегетационного периода.

Ранние и поздние сроки уборки урожая значительно снижают продолжительность хранения плодов. Если плоды снимать слишком рано, то происходит значительная потеря урожая за счёт небольшой массы не полностью сформировавшихся плодов.

Таблица 1

Характеристика плодов яблони сортов осеннего срока созревания, допущенных для выращивания в Средневолжском регионе

\begin{tabular}{|c|l|}
\hline Название & \multicolumn{1}{|c|}{ Характеристика } \\
\hline Спартак* & $\begin{array}{l}\text { Плоды ниже средней и средней величины, массой 80 г, максимум - } 120 \\
\text { г, плоскоокруглой формы, не выравненные. Плодоножка короткая или } \\
\text { средней длины. Кожица гладкая, средней плотности, с сильным } \\
\text { сизоватым восковым налетом. Мякоть белая с кремовым оттенком, } \\
\text { средней плотности, сочная, мелкозернистая, ароматная. Вкус хороший, } \\
\text { кисло-сладкий. Осеннего срока потребления. Плоды хранятся 1,0-1,5 } \\
\text { волжская } \\
\text { красавица }\end{array}$ \\
$\begin{array}{l}\text { Плоды ниже средней величины, массой 90 г, максимум 110 г, } \\
\text { выравненные, плоскоокруглой формы, слаборебристые. Плодоножка } \\
\text { средней длины и толщины. Кожица светло-кремовая с розовым или } \\
\text { ярко-розовым размытым румянцем на большей части плода. Мякоть } \\
\text { белая, средней плотности, мелкозернистая, ароматная. Вкус очень } \\
\text { хороший, кисло-сладкий. Позднеосеннего срока потребления, хранятся } \\
\text { до февраля. }\end{array}$ \\
\hline
\end{tabular}




\begin{tabular}{|c|c|}
\hline $\begin{array}{c}\text { Коричневое } \\
\text { полосатое }\end{array}$ & $\begin{array}{l}\text { Плоды ниже средней величины, массой 70-90 г, плоскоокруглой формы. } \\
\text { Плодоножка относительно толстая, короткая. Кожица гладкая, почти } \\
\text { сухая, тонкая, плотная, блестящая, зеленовато-желтая, при хранении - } \\
\text { желтая. Покровная окраска темно-красная, полосатая и мелкокрапчатая } \\
\text { на большей части плода. Мякоть желто-белая, под кожицей нередко } \\
\text { розоватая, нежная, средней сочности. Вкус очень хороший, кисловато- } \\
\text { сладкий, со своеобразным горьковатым привкусом и ароматом. }\end{array}$ \\
\hline $\begin{array}{l}\text { Орловское } \\
\text { полосатое }\end{array}$ & $\begin{array}{l}\text { Плоды средней величины, массой } 130 \text { г, максимум - } 150 \text { г, } \\
\text { продолговато-конической формы, гладкие или слаборебристые. } \\
\text { Плодоножка короткая или средней длины, относительно тонкая. Кожица } \\
\text { гладкая, блестящая, маслянистая, тонкая, с сизоватым восковым } \\
\text { налетом. Окраска кожицы зеленовато-желтая с интенсивными } \\
\text { пурпуровыми и малиновыми полосами. Мякоть белая, нежная, средней } \\
\text { плотности, очень сочная, мелкозернистая, с сильным ароматом. Вкус } \\
\text { кисло-сладкий, гармоничный, очень хороший. Позднеосеннего срока } \\
\text { потребления, плоды хранятся до конца декабря. }\end{array}$ \\
\hline \multirow[t]{2}{*}{$\begin{array}{c}\text { Осеннее } \\
\text { полосатое }\end{array}$} & $\begin{array}{l}\text { Плоды средней величины, округлой или округло-конической формы, } \\
\text { часто неравнобокие. Плодоножка длинная или средней длины, средней } \\
\text { толщины. Кожица толстая, плотная, слабомаслянистая, блестящая, с } \\
\text { тонким налетом. }\end{array}$ \\
\hline & $\begin{array}{l}\text { Основная окраска бледно-желтая, покровная - оранжево-красная, } \\
\text { размытая, с более темными полосками и точками. Мякоть желтоватая, } \\
\text { иногда под кожицей розовая, средней плотности, нежная, сочная. Вкус } \\
\text { кисло-сладкий, с приятным винным привкусом, гармоничный, очень } \\
\text { хороший. Осеннего срока потребления, плоды хранятся до начала } \\
\text { декабря. }\end{array}$ \\
\hline Тень & $\begin{array}{l}\text { Плоды средние и крупные, массой } 150 \text { г, средней одномерности, по } \\
\text { форме слаборебристые. Окраска золотисто-желтая с ярко-розовым } \\
\text { полосатым румянцем. Мякоть светло-желтая, плотная, колющаяся, } \\
\text { мелкозернистая, очень сочная. Вкус кисло-сладкий с сильным ароматом. }\end{array}$ \\
\hline Жигулёвское* & $\begin{array}{l}\text { Плоды выше среднего размера или крупные, плоскоокруглой формы, } \\
\text { широкоребристые, иногда с золотисто оржавленными бугорками. } \\
\text { Плодоножка средней длины и толщины. Кожица гладкая, прочная, } \\
\text { золотисто-желтая с красно-оранжевым размытым и ярко карминово- } \\
\text { красным полосатым румянцем на большей части плода. Мякоть } \\
\text { кремовая, сочная, нежная, плотная, ароматная. Вкус очень хороший, } \\
\text { сладко-кислый. Позднелетнего или позднеосеннего срока потребления. } \\
\text { Плоды хранятся 2-3 месяца. }\end{array}$ \\
\hline $\begin{array}{c}\text { Самарский } \\
\text { рубин* }\end{array}$ & $\begin{array}{l}\text { Плоды средние, средней массой } 110 \text { г, приплюснутые, правильной } \\
\text { формы, средней одномерности, поверхность плода широкоребристая. }\end{array}$ \\
\hline
\end{tabular}




\section{ТРАДИЦИИ И ИННОВАЦИИ В СОВРЕМЕННОЙ НАУКЕ И ОБРАЗОВАНИИ: ТЕОРИЯ И ПЕРЕДОВАЯ ПРАКТИКА}

\begin{tabular}{|c|l|}
\hline \hline & $\begin{array}{l}\text { Плодоножка средней длины и толщины, изогнутая. Основная окраска } \\
\text { светло-желтая, покровная - на большей части плода сильно выраженная, } \\
\text { штриховато-полосатая, розово-красная. Мякоть белая, средней } \\
\text { плотности, нежная, мелкозернистая, сочная. Вкус сладкий, с пряностью, } \\
\text { со слабым ароматом. Транспортабельность плодов хорошая. } \\
\text { Позднеосенний, универсальный. }\end{array}$ \\
\hline Память & $\begin{array}{l}\text { Плоды средние, средней массой } 140 \text { г, приплюснуто-шаровидные, } \\
\text { правильной формы, средней одномерности. Плодоножка средней длины } \\
\text { и толщины. Основная окраска беловатая, покровная - на большей части } \\
\text { плода сильно выраженная, размытая, темно-красная. Мякоть беловато- } \\
\text { зеленоватая, средней плотности, очень нежная, мелкозернистая, сочная. } \\
\text { Вкус кисло-сладкий, с пряностью, со средним ароматом. } \\
\text { Позднеосенний, универсальный. }\end{array}$ \\
\hline
\end{tabular}

* Оригинатор: ГБУ Самарской области НИИ садоводства и лекарственных культур «Жигулевские сады» (г. Самара).

Они твердые, содержат много клетчатки, протопектина, в них не сбалансирован минеральный состав, меньше содержится сахаров, кислот, ароматических веществ, витаминов, плоды не достаточно окрашены, что ухудшает их вкусовые и товарные качества. У незрелых и не сформировавшихся плодов в период хранения основная окраска не изменяется нормальным образом, они остаются зелёными, чаще происходит побурение кожицы (загар), плоды поражаются подкожной пятнистостью, теряют много воды и сморщиваются.

Поздние сроки съёма плодов также приводят к потере урожая за счёт падалицы. В таких плодах уже начался процесс старения, снижена сочность и качественный состав, плотность мякоти и транспортабельность, что не обеспечивает пригодность их к длительному хранению. Задержка со сбором плодов на 3-5 дней сокращает срок хранения на 1-2 месяца. Поэтому, крайне важно, как можно более точно для каждого сорта определить оптимальный срок съёмной зрелости плодов, чтобы основную их массу убрать в кратчайшие оптимальные сроки. Кроме того, при поздних сроках уборки урожая сокращается послеуборочный период вегетации деревьев. Это приводит к меньшему накоплению запасных веществ и продуктов фотосинтеза, что, в итоге, снижает морозостойкость и зимостойкость яблони.

При определении съёмной зрелости плодов яблони можно принимать во внимание такие показатели как число дней от цветения до созревания (возраст 
плодов), размер плода, основная и покровная окраска плода, твердость кожицы и мякоти, вкус и аромат плодов, сумма эффективных температур вегетационного периода, интенсивность дыхания плодов, химический состав и его изменения, развитие и окраска семян, прочность прикрепления к плодовым образованиям $[10,11]$.

Приведённые критерии наступления съёмной зрелости плодов яблони в пределах даже одного сорта могут значительно изменяться в зависимости от факторов внешней среды (район произрастания, агротехнические приёмы выращивания, погодные условия вегетационного периода и т.д.).

Таблица 2

Характеристика плодов яблони сортов зимнего срока созревания, допущенных для выращивания в Средневолжском регионе

\begin{tabular}{|c|l|}
\hline Название & \multicolumn{1}{c|}{ Характеристика } \\
\hline Утёс* & $\begin{array}{l}\text { Плоды одномерные, массой } 125 \text { г, приплюснутые, слаборебристые, } \\
\text { правильной формы. Плодоножка средняя, прямая. Окраска плода } \\
\text { золотисто-желтая с красным полосатым румянцем на меньшей части } \\
\text { плода. Подкожные точки слабозаметные. Мякоть кремовая, средней } \\
\text { плотности, колющаяся, мелкозернистая, сочная. Вкус кисло-сладкий. }\end{array}$ \\
\hline Антоновка & $\begin{array}{l}\text { Плоды среднего размера, массой 120-150 г, максимальной - 300 г, не } \\
\text { выравненные. Форма варьирует от плоскоокруглой до овально } \\
\text { конической. Кожица слабомаслянистая, блестящая с характерным } \\
\text { сильным ароматом. Основная окраска зеленовато-желтая, при хранении } \\
\text { - светло-соломенно-желтая. Покровная окраска отсутствует, иногда } \\
\text { слабо-розовая или кирпичная, а также в виде золотистого загара. } \\
\text { Подкожные точки многочисленные, крупные, белые, хорошо заметные. } \\
\text { Мякоть слегка желтоватая, сочная, средней плотности, зернистая. Вкус } \\
\text { хороший с некоторым избытком кислоты и своеобразным ароматом. }\end{array}$ \\
\hline Куйбышевское* & $\begin{array}{l}\text { Плоды средней и выше средней величины, массой 155 г, не } \\
\text { выравненные, плоскоокруглой формы, широкоребристые, в нижней } \\
\text { части плода дольчатые. Плодоножка короткая, толстая. Кожица } \\
\text { прочная, не грубая, со слабым восковым налетом, светло-зеленая или } \\
\text { желтовато-зеленая. Покровная окраска очень слабая, розовая на } \\
\text { небольшой части плода. Подкожные точки многочисленные, крупные, } \\
\text { беловато-зеленые, слабозаметные. Мякоть белая, с зеленоватым } \\
\text { оттенком, сочная, ароматная, плотная, мелкозернистая. Вкус отличный, } \\
\text { кисло-сладкий. }\end{array}$ \\
\hline $\begin{array}{l}\text { Плоды ниже средней величины, массой 100-110 г, плоскоокруглой } \\
\text { формы, одномерные, неравнобокие. Плодоножка короткая, средней }\end{array}$ \\
\hline
\end{tabular}




\begin{tabular}{|c|c|}
\hline & $\begin{array}{l}\text { толщины. Кожица гладкая, плотная, средней толщины, со слабым } \\
\text { восковым налетом, светло-зеленая. Покровная окраска тускло- } \\
\text { вишневая, размытая, слабая на меньшей части плода. Подкожные точки } \\
\text { многочисленные, крупные, белые, хорошо заметные на всей } \\
\text { поверхности плода. Мякоть беловато-зеленоватая, сочная, плотная, } \\
\text { мелкозернистая, со слабым ароматом. Вкус хороший, кисло-сладкий. }\end{array}$ \\
\hline Северный синап & $\begin{array}{l}\text { Плоды ниже средней величины и средние, массой от } 70 \text { до } 150 \text { г, } \\
\text { продолговато-слабоконической формы, асимметричные, очень слабо } \\
\text { ребристые, почти гладкие. Плодоножка средней длины или короткая, } \\
\text { средней толщины, очень прочно прикреплена к дереву. Кожица средней } \\
\text { плотности, гладкая, при хранении становится маслянистой. Окраска } \\
\text { кожицы желтовато-зеленая с размытым буровато-красным румянцем на } \\
\text { меньшей части плода. Подкожные точки светлые, хорошо заметные. } \\
\text { Мякоть белая или слегка зеленоватая, сочная, мелкозернистая, плотная. } \\
\text { Вкус хороший, кисловато-сладкий, с пряностью. Позднезимнего срока } \\
\text { потребления. Плоды хранятся до мая. }\end{array}$ \\
\hline $\begin{array}{c}\text { Башкирский } \\
\text { красавец }\end{array}$ & $\begin{array}{l}\text { Плоды ниже средней величины, массой } 88 \text { г, максимальной - } 107 \text { г, } \\
\text { округло-конической или продолговато-конической правильной формы. } \\
\text { Поверхность плода широкоребристая, сглаженная. Плодоножка } \\
\text { средней длины и толщины, слабо прикреплена к ветке. Кожица } \\
\text { плотная, грубая, с восковым налетом, зеленовато-желтая. Покровная } \\
\text { окраска ярко-красная с полосками и штрихами на размытом фоне на } \\
\text { большей части плода. Подкожные точки хорошо заметные, белые, } \\
\text { особенно крупные у воронки. Мякоть зеленовато-белая, сочная, } \\
\text { относительно плотная, хрустящая, мелкозернистая со слабым ароматом. } \\
\text { Вкус хороший, кисло-сладкий с пряностью. }\end{array}$ \\
\hline Вете & $\begin{array}{l}\text { Плоды крупные, массой } 128 \text { г, одномерные, бочковидные, } \\
\text { широкоребристые, правильной формы. Плодоножка средняя. Основная } \\
\text { окраска золотисто-желтая, покровная по большей части плода с } \\
\text { красными штрихами и полосками. Подкожных точек много, средние, } \\
\text { зелёные, слабозаметные. Мякоть белая, иногда желтоватая, средней } \\
\text { плотности, колющаяся, мелкозернистая, сочная, кисло-сладкого вкуса с } \\
\text { ароматом. }\end{array}$ \\
\hline Звёздочка & $\begin{array}{l}\text { Плоды ниже средней величины, массой } 70 \text { г, максимум - } 85 \text { г, } \\
\text { плоскоокруглой, слегка конической формы. Плодоножка короткая, } \\
\text { толстая. Кожица плотная, гладкая, с сильным восковым налетом, } \\
\text { зеленовато-желтая с темно-красным, размытым румянцем на большей } \\
\text { части плода. Подкожные точки многочисленные, мелкие, белые, } \\
\text { хорошо заметные. Мякоть зеленоватая, мелко зернистая, средней } \\
\text { плотности, средней сочности. Вкус кисло-сладкий, очень хороший. }\end{array}$ \\
\hline
\end{tabular}




\section{ТРАДИЦИИ И ИННОВАЦИИ В СОВРЕМЕННОЙ НАУКЕ И ОБРАЗОВАНИИ: ТЕОРИЯ И ПЕРЕДОВАЯ ПРАКТИКА}

\begin{tabular}{|c|c|}
\hline $\begin{array}{c}\text { Зимнее } \\
\text { полосатое }\end{array}$ & $\begin{array}{l}\text { Плоды средней массой } 88 \text { г, одномерные, округлые, плоскоокруглые. } \\
\text { Окраска золотисто-желтая с ярко-красным полосатым румянцем. } \\
\text { Подкожных точек много, они хорошо заметные. Мякоть кремовая, } \\
\text { рыхлая, нежная, сочная. Вкус кисло-сладкий со слабым ароматом. } \\
\text { Период потребления: зимний. }\end{array}$ \\
\hline Куликовское & $\begin{array}{l}\text { Плоды крупные, массой } 140 \text { г, одномерные, округлые, правильной } \\
\text { формы. Плодоножка короткая, прямая. Окраска золотисто-желтая с } \\
\text { пурпуровым размытым румянцем на большей части плода. Подкожные } \\
\text { точки зеленые, слабозаметные. Мякоть белая, средней плотности, } \\
\text { нежная, мелкозернистая, сочная. Вкус кисло-сладкий, со слабым } \\
\text { ароматом. }\end{array}$ \\
\hline Мартовское & $\begin{array}{l}\text { Плоды средней величины, массой 140-150 г, плоскоокруглой } \\
\text { правильной формы. Плодоножка толстая, короткая. Кожица плотная, } \\
\text { гладкая. Окраска зеленовато-желтая, без румянца или со слабым } \\
\text { буровато-красным полосатым и крапчатым загаром на меньшей части } \\
\text { плода. Подкожные точки серые, крупные, хорошо заметные на всей } \\
\text { поверхности плода. Мякоть зеленовато-белая, средней плотности, } \\
\text { мелкозернистая, сочная. Вкус кисло-сладкий, хороший. }\end{array}$ \\
\hline $\begin{array}{c}\text { Пепин } \\
\text { шафранный }\end{array}$ & $\begin{array}{l}\text { Плоды ниже средней величины, массой } 85 \text { г, продолговато-яйцевидной } \\
\text { или овально-конической формы. Плодоножка длинная, тонкая. Кожица } \\
\text { гладкая, маслянистая, оранжево-желтая с темно-красным размытым } \\
\text { полосатым румянцем. Подкожные точки мелкие, желтоватые, хорошо } \\
\text { заметные. Мякоть кремовато-желтая, средней плотности, сочная, } \\
\text { нежная. Вкус винно-сладкий, очень хороший, с тонким ароматом. }\end{array}$ \\
\hline $\begin{array}{c}\text { Синап } \\
\text { орловский }\end{array}$ & $\begin{array}{l}\text { Плоды крупные, продолговато-конические, одномерные, желтовато- } \\
\text { зеленые и золотисто-желтые с легким румянцем. }\end{array}$ \\
\hline $\begin{array}{l}\text { Московское } \\
\text { зимнее }\end{array}$ & $\begin{array}{l}\text { Плоды крупные, массой 200-280 г, не выравненные, округлой или } \\
\text { округло-конической правильной формы. Плодоножка очень короткая, } \\
\text { средней толщины. Окраска зеленовато-желтая с темно-красным } \\
\text { размытым полосато-штриховатым румянцем. Мякоть слегка } \\
\text { желтоватая, средней плотности, сочная, мелкозернистая. Вкус кисло- } \\
\text { сладкий с легкой пряностью и ароматом. }\end{array}$ \\
\hline
\end{tabular}

* Оригинатор: ГБУ Самарской области НИИ Садоводства и лекарственных культур «Жигулевские сады» (г. Самара).

В этой связи каждый из этих показателей не может быть определяющим при выявлении оптимальной съемной зрелости, а только лишь как составляющий в комплексе признаков.

Для более точного определения срока уборки урожая плодов конкретного сорта яблони, в настоящее время, применяют метод йодкрахмальной пробы, 
основанный на окрашивании крахмала йодом в синий цвет. Для этого с разных сторон пяти деревьев отбирают средний образец плодов массой 1,0-1,5 кг. Одну часть отобранных плодов разрезают на половинки поперек для определения степени зрелости, а вторую часть пробы продольно для определения склонности к осыпанию.

Техника определения зрелости достаточно проста. Готовят раствор йода (15 г йодистого калия и 5 г кристаллического йода растворяются в 500 г воды), а затем разрезанные части плода поперек погружают на несколько секунд в свежеприготовленный раствор, вынимают и удаляют фильтровальной бумагой избыток раствора йода, обсушивают на воздухе. Из-за реакции крахмала плодов с йодом на срезах в местах содержания крахмала появляются темноокрашенные участки.

Оценку содержания в плодах крахмала проводят по пятибалльной шкале:

5 баллов - крахмала много, поверхность среза от семенного гнезда до кожицы черно-синего цвета, плоды незрелые;

4 балла - не окрашены незначительные участки поверхности среза у плодоножки и у семенного гнезда;

3 балла - на тёмном фоне по всей поверхности среза появляются светлые пятна, под кожицей слой мякоти остаётся темноокрашенным;

2 балла - тёмное окрашивание под кожицей и незначительное потемнение отдельных участков мякоти;

1 балл - незначительное окрашивание только под кожицей плода;

0 баллов - отсутствие синей окраски, вся поверхность среза светлая.

Уборку урожая плодов большинства сортов для длительного хранения следует проводить при оценке 3-4 балла (ткани в зоне семенных камер и плодоножки не окрашиваются в синий цвет). Для транспортирования необходимо использовать плоды с оценкой 2-3 балла, для краткосрочного хранения - 1-2 балла. Содержание крахмала только под кожицей (1 балл) свидетельствует о наступлении потребительской зрелости плодов. Для установления оптимального срока съёма плодов того или иного сорта содержание крахмала по йодкрахмальной пробе необходимо определять каждые 5-6 дней, начиная за 15-20 дней до наступления среднемноголетней даты уборки урожая.

Определение содержания в плодах крахмала по йодкрахмальной пробе проводят также для установления склонности конкретного сорта к 
преждевременному опадению [12]. У сортов яблони склонных к преждевременному опадению плодов у плодоножки происходит интенсивный гидролиз крахмала. В связи с этим, на продольных разрезах плодов по йодкрахмальной пробе в динамике наблюдают за темпами гидролиза крахмала в сахара или за интенсивностью исчезновения синей окраски в зоне плодоножки.

Вместе с определением начала съёмной зрелости плодов яблони устанавливают также и примерный период их уборки. Для сортов осеннего срока созревания ориентировочно период уборки урожая составляет 5-7 дней, зимнего срока созревания 8-14 дней. В первую очередь проводят уборку урожая сортов, склонных к быстрому опадению плодов.

При определении сроков уборки урожая следует учитывать также и склонность плодов различных сортов к поражению в период хранения болезнями физиологического происхождения. В начале съёмной зрелости убирают плоды сортов, которые при хранении в большей мере поражаются пятнистостью Джонатана, водянистым разложением, побурением мякоти и сердечка. В конце периода съёмной степени зрелости убирают плоды сортов, которые склонны к увяданию, поражению загаром, подкожной пятнистостью (Северный синап, Антоновка обыкновенная, Мартовское, Синап орловский).

Съём плодов яблони необходимо проводить в сухую погоду после опадения росы. После прошедших дождей плоды должны обсохнуть на дереве. Нельзя снимать с деревьев плоды мокрыми, поскольку повышается риск микробиологических заболеваний и в период хранения плоды быстро буреют, поражаются загаром и плодовой гнилью.

Для длительного хранения плоды яблони убирают вручную с плодоножкой, не надавливая на них и не делая пятен. Плод берут в ладонь, охватывают его всеми пальцами, указательным пальцем нажимают на плодоножку в месте прикрепления её к плодовой ветви, приподнимают плод к верху и отодвигают в сторону. Не нужно тянуть плоды вниз и дергать, так как это приводит к вырыванию или обламыванию плодоножек, повреждению кожицы плодов и повреждению плодовых образований.

При прямой отгрузке плодов потребителю уборку урожая можно проводить непосредственно в ящики на 22-25 кг, а для закладки на хранение лучше всего применять контейнеры на 250-300 кг и тележки-контейнеровозы. В контейнерах плоды меньше повреждаются, а нагрузка высокого слоя плодов 


\section{ТРАДИЦИИ И ИННОВАЦИИ В СОВРЕМЕННОЙ НАУКЕ И ОБРАЗОВАНИИ: ТЕОРИЯ И ПЕРЕДОВАЯ ПРАКТИКА}

(более 50 см) практически не передается и не повреждает низлежащие плоды. После заполнения контейнеров плоды из сада доставляют к месту выгрузки и хранения.

В первые дни после уборки плоды дышат более интенсивно, что связано с реакцией на отделение их от материнского растения. В первый день после съёма яблоки дышат в 2 раза интенсивнее, чем через 5 дней. Интенсивность дыхания плодов ещё больше возрастает, если они убраны при достаточно высокой температуре воздуха. Только один день хранения яблок после съёма при температуре $+18 \ldots+20^{\circ} \mathrm{C}$ сокращает срок их хранения на 10-15 дней.

Если плоды яблони, убранные в тёплую погоду, сразу поместить на хранение в камеру холодильника, в которой уже имеются охлаждённые плоды, то произойдёт отпотевание охлаждённых яблок. Образовавшийся конденсат влаги на поверхности плодов может стать очагом микробиологических заболеваний (гнили). В этом случае нужно проводить предварительное охлаждение плодов. Его осуществляют в холодильной камере краткосрочного хранения при температуре $+4 \ldots+5^{\circ} \mathrm{C}$, постепенно загружая камеру в течение 2 3 суток с постоянным воздухообменом, что позволяет охладить плоды без образования конденсата на их поверхности. В камеру длительного хранения охлаждённые плоды яблок должны загружаться в холодильную камеру постепенно по 10-15\% объёма камеры в сутки, но не более 8-10 дней.

При выгрузке яблок из камеры после хранения и размещение в теплом помещении также приводит к отпотеванию плодов. Поэтому после завершения основного периода хранения плоды сначала помещают в камеру краткосрочного хранения, где проводят постепенное повышение температуры продукции на $5 . . .6^{\circ} \mathrm{C}$ в сутки, а затем направляют плоды на товарную обработку и реализацию в свежем виде или на промышленную переработку для производства сока, пюре, сидра, повидла, джема и других видов продукции.

Качество плодов яблони для промышленной переработки регламентируется стандартом ГОСТ 27572-2017 «Яблоки свежие для промышленной переработки. Технические условия» [13] и подразделяется на первый и второй товарные сорта.

Яблоки свежие первого товарного сорта для промышленной переработки по внешнему виду должны быть здоровые, целые, свежие, чистые, вполне развившиеся, типичной для данного помологического сорта формы и окраски, без повреждений сельскохозяйственными вредителями, без механических 
повреждений, без излишней внешней влажности, с плодоножкой и без нее. Допускаются повреждения (нажимы, градобоины), зарубцевавшиеся повреждения сельскохозяйственными вредителями (кроме плодожорки) и болезнями общей площадью не более $3 \mathrm{~cm}^{2}$, в том числе не более трех пятен парши (Venturia inaequalis), каждое диаметром не более 0,3 см.

Запах и вкус, свойственные помологическому сорту без постороннего запаха и/или привкуса. Массовая доля растворимых сухих веществ в соке плодов не менее $10,0 \%$. Размер плодов по наибольшему поперечному диаметру не менее 6,0 см. Массовая доля плодов, менее установленного размера, не более чем на $1 \mathrm{~cm}$, не более $10,0 \%$. Массовая доля плодов с однимдвумя засохшими повреждениями плодожоркой не более $2,0 \%$.

Плоды яблони для промышленной переработки должны быть в состоянии технической, потребительской однородной степени зрелости, при которой они достигают оптимальных технологических свойств, необходимых для производства определенных продуктов. Для производства яблочных соков с высокими вкусовыми и питательными свойствами наиболее пригодны сорта яблок осенне-зимних сроков созревания с плотной мякотью, которая при дроблении дает мезгу зернистой структуры, хорошо поддающуюся прессованию. В плодах содержание сухих веществ должно составлять 14-17\%, сахаров 10-14\%, соотношение сахара к кислоте (сахарокислотный индекс) от 15 до 20, выход сока не менее $60 \%$, а также высокое содержание витамина С (не менее 20 мг/100 г) и Р-активных веществ (не менее 250 мг/100 г).

Для производства компотов наиболее пригодны плоды яблони с умеренной кислотностью $(0,3-0,4 \%)$ и плотной мякотью, которые при стерилизации не изменяют свой цвет на желтый или красный. При производстве высококачественного пюре необходимо использовать плоды с нежной мякотью, сильным ароматом, содержанием не менее $12,0 \%$ растворимых сухих веществ, 0,5-1,0\% кислот, соотношением сахара к кислоте от 10 до 20.

При производстве яблочного сока с целью удаления загрязнения плоды моют на двух последовательно установленных моечных машинах. Мытые плоды инспектируют, удаляя пораженные болезнями и вредителями, которые как источник микроорганизмов могут оказывать негативное влияние на цвет готового продукта. После мойки плоды на дисковых или тёрочных дробилках измельчают на частицы размером 2-6 мм. 


\section{ТРАДИЦИИ И ИННОВАЦИИ В СОВРЕМЕННОЙ НАУКЕ И ОБРАЗОВАНИИ: ТЕОРИЯ И ПЕРЕДОВАЯ ПРАКТИКА}

Полученную мезгу нагревают до температуры $60-75^{\circ} \mathrm{C}$. В процессе нагревания мезги коагулируют и обезвоживаются белковые вещества, входящие в состав клеток, увеличивается проницаемость клеток и выход сока, а также происходит инактивация благоприятной среды для развития микроорганизмов. Наиболее эффективна тепловая обработка мезги, полученной из плодов с низкой сокоотдачей. Нагревание мезги при чрезмерно высоких температурах и большой продолжительности способствует переходу в сок полифенольных и других веществ, которые ухудшают его вкус. Кроме того, происходит увеличение растворимого пектина в результате гидролиза протопектина, что затрудняет прессование и фильтрование.

Подготовленную мезгу сразу подают на прессование на гидравлических прессах периодического или непрерывно-шнекового действия, так как при измельчении нарушается целостность клеточных стенок, и высвобождаются полифенольные ферменты. При участии кислорода воздуха полифенольные и другие легкоокисляемые соединения окисляются, что приводит к потемнению и ухудшению вкуса и запаха сока.

Отжатый сок, который содержит пектиновые, полифенольные вещества, некоторую часть крахмала и азотистых соединений, при производстве осветлённых соков осветляют комбинированными способами с применением пектолитических и амилолитических ферментов и других осветляющих веществ.

Осветлённый сок фильтруют и направляют на подогрев и фасование. При изготовлении соков с сахаром или купажированных смешивание соков и добавление сахара осуществляют перед нагреванием. Сок, фасуемый в мелкую тару с последующей стерилизацией, нагревают до $75-80^{\circ} \mathrm{C}$ и фасуют в подготовленные бутылки или банки. При производстве сока с витамином С в горячий сок добавляют аскорбиновую кислоту, перемешивают 5-10 минут и сразу направляют на фасование. Наполненную тару укупоривают и проводят стерилизацию (пастеризацию) при температуре 85,90 или $100^{\circ} \mathrm{C}$ в течение 10 20 минут в зависимости от кислотности сока и емкости тары.

Наиболее простым способом переработки плодов яблони является их сушка. Для сушки лучше всего использовать плоды с кисло-сладким вкусом. Плоды до сушки сортируют по качеству, отбраковывают дефектные и повреждённые экземпляры, моют их, если даже яблоки по внешнему виду являются чистыми. Сушить яблоки лучше очищенными от кожицы и с 
удалённой сердцевиной. Очищенные яблоки разрезают на кружки толщиной 45 мм. Можно сушить неочищенные яблоки с семенной камерой. В этом случае после мойки плоды сразу разделяют на кружки или дольки такой же толщины.

Разрезанные плоды очень быстро темнеют на воздухе, что связано с окислением дубильных веществ и образованием тёмноокрашенных соединений - флабофенов [14]. В этой связи, сразу после очистки и резки яблоки необходимо до их сушки погрузить в $1 \%$ раствор поваренной соли, опрыснуть лимонным соком или провести бланширование, опуская кружки и дольки яблок на $10-15$ с в горячую $\left(95-100^{\circ} \mathrm{C}\right)$ воду. При бланшировании в плодах частично снижается содержание сахаров, кислот и витаминов. Сушку проводят в сушильном шкафу при температуре $65-80^{\circ} \mathrm{C}$ в течение 5-6 часов. Высушенные кружки или дольки яблок должны быть эластичными, светло-желтой окраски.

Повидло яблочное получают путем уваривания плодов до получения густой желирующей консистенции. Для производства повидла пригодны некондиционные, не самые красивые, кислые плоды яблок с высоким содержание пектиновых веществ. Яблоки освобождают от жесткой кожицы, гнили и семенной камеры. После этого проводят процесс уваривания яблок с $50 \%$ количеством сахара к массе сырья. Для разнообразия вкуса и аромата повидла можно использовать корицу и гвоздику, которые очень хорошо сочетаются с яблоками. Если для приготовления повидла используются яблоки с высоким содержанием сахаров, то для придания кислинки можно немного добавить кислоты лимонной.

Уваривание яблок с сахаром и получения повидла необходимо проводить до получения густой однородной светло-коричневой сохраняющую свою форму консистенции с кисло-сладким вкусом. После длительной термической обработки в повидле сохраняется около $30 \%$ полезных веществ от исходного их содержания в яблоках. Сохраняются в основном пектиновые вещества и бетакаротин, а витамины практически полностью разрушаются.

\section{Список литературы}

1. Галашева, А. М. Биохимическая оценка плодов сортов яблони на слаборослых вставочных подвоях / А.М. Галашева, Н.Г. Красова, М.А. Макаркина // Селекция и сорторазведение садовых культур. Сборник Всероссийского научно-исследовательского института селекции плодовых культур. - Орел, 2007. - С. 47-55. 
2. Patocka, J. Malus domestica: A Review on Nutritional Features, Chemical Composition, Traditional and Medicinal Value / J. Patocka, K. Bhardwaj, B. Klimova et al // Plants. - 2020. - № 9 (1408). http://dx.doi.org/10.3390/plants9111408.

3. Приказ Министерства здравоохранения Российской Федерации от 19 августа 2016 года № 614 «Об утверждении Рекомендаций по рациональным нормам потребления пищевых продуктов, отвечающих современным требованиям здорового питания (с изменениями на 1 декабря 2020 года)». http://docs.cntd.ru/document/420374878. Дата обращения 15 февраля 2021 года.

4. Дулов, М.И. Лабораторный практикум по технологии хранения продукции растениеводства / М.И. Дулов, А.П. Журавлев, Л.А. Журавлева. Самара, 2007. - 269 с.

5. Дулов, М. И. Технология хранения продукции растениеводства / М.И. Дулов, А.П. Журавлев, Л.А. Журавлева. - Самара : РИЦ СГСХА, 2013. $295 \mathrm{c}$.

6. ГОСТ 34314-2017 Яблоки свежие, реализуемые в розничной торговле. Технические условия. - М.: Стандартинформ, 2018. - 31 с.

7. Марцинкевич, Д. И. Естественная убыль массы свежих плодов яблони белорусского сортимента при кратковременном и длительном хранении / Д.И. Марцинкевич, А.М. Криворот // Плодоводство. - Самохваловичи, 2017. Т. 29. - С. 164-168.

8. Никитин, А.Л. Рекомендации по длительному хранению плодов иммунных и высокоустойчивых к парше сортов яблони селекции ВНИИСПК в фруктохранилищах-холодильниках (для средней полосы России) : [производственно-методические рекомендации] / А.Л. Никитин, М.А. Макаркина. - Орел: ВНИИСПК, 2018. - 48 с.

9. Гудковский, В. А. Высокоточные технологии хранения плодов яблони основа обеспечения их качества (достижения, задачи на перспективу) / В.А. Гудковский, Л.В. Кожина, Ю.Б. Назаров [и др.] // Достижения науки и техники АПК. - 2019. - № 2. - С. 61-67.

10. Причко, Т.Г. Уборка, хранение и товарная обработка яблок. Рекомендации / Т.Г. Причко. - Краснодар, 2015. - 122 с.

11. Причко, Т. Г. Критериальные показатели, характеризующие съемную зрелость плодов яблони селекции СКФНЦСВВ / Т.Г. Причко, Н.В. Дрофичева, Т.Л. Смелик, М.Г. Германова // Новые технологии. - 2019. - Вып. 4 (50). C. 183-191. 
12. Хранение продукции растениеводства [Электронный ресурс] / С.А. Семина, О. Н. Кухарев, Н. И. Остробородова [и др.]. - Пенза : РИО ПГАУ, 2018. - 87 с. - Режим доступа: https://rucont.ru/efd/652020.

13. ГОСТ 27572-2017 Яблоки свежие для промышленной переработки. Технические условия. - М.: Стандартинформ, 2017. - 12 с.

14. Пискунова, Н.А. Технология хранения и переработки плодов и овощей: учебник / Н. А. Пискунова, С. А. Масловский, Л. Э. Гунар. - М.: РГАУ-МСХА им. К. А. Тимирязева, 2018. - 162 с.

(C) М.И. Дулов, 2021 
УДК 378.147

\title{
СТРУКТУРНЫЕ И ДИНАМИЧЕСКИЕ ОСОБЕННОСТИ АГРАРНОГО ПРОИЗВОДСТВА ТАМБОВСКОЙ ОБЛАСТИ
}

\section{Попова Вера Борисовна}

к.э.Н., доцент

Лосева Алла Сергеевна

к.э.н., доцент

Фецкович Игорь Владимирович

к.э.н., доцент

ФГБОУ ВО Мичуринский ГАУ

\begin{abstract}
Аннотация: В статье изучена институциональная структура продукции сельского хозяйства региона; дана оценка существенности ее структурнодинамических и структурно-территориальных различий; произведено сравнение отраслевой структуры аграрного производства в хозяйствах разных категорий. Охарактеризованы динамические особенности сельскохозяйственного производства в различных категориях хозяйств региона за последние десять лет, отражающие диверсификационные процессы в отрасли. Выявлены адаптационные возможности сельскохозяйственных организаций, проявляющиеся в более высоких по сравнению с другими категориями товаропроизводителей средних темпах роста аграрного производства в послекризисные годы по сравнению с докризисным периодом. Показан конкурентный характер сельского хозяйства области, выражающийся в опережающем общероссийские и среднерегиональные значения среднегодовом приросте физического объема продукции. Отражена высокая динамичность животноводства, связанная с приоритетным инвестированием ее подотраслей путем развития производства в крупных аграрных формированиях.

Ключевые слова: валовая продукция сельского хозяйства, аграрное производство, категории хозяйств, отраслевая структура, структурные сдвиги и различия, индекс физического объема продукции сельского хозяйства.
\end{abstract}




\title{
STRUCTURAL AND DYNAMIC FEATURES OF AGRICULTURAL
} PRODUCTION IN THE TAMBOV REGION

\section{Popova Vera Borisovna \\ Loseva Alla Sergeevna Fetskovich Igor Vladimirovich}

\begin{abstract}
The article examines the institutional structure of agricultural production in the region; assesses the significance of its structural-dynamic and structural-territorial differences; compares the sectoral structure of agricultural production in farms of different categories. The article describes the dynamic features of agricultural production in various categories of farms in the region over the past ten years, reflecting the diversification processes in the industry. The adaptive capabilities of agricultural organizations are revealed, which are manifested in higher average growth rates of agricultural production in the post-crisis years compared to the pre-crisis period in comparison with other categories of commodity producers. The competitive nature of agriculture in the region is shown, which is expressed in the average annual increase in the physical volume of production that is ahead of the national and regional average values. The high dynamics of animal husbandry associated with priority investment in its sub-sectors through the development of production in large agricultural formations is reflected.
\end{abstract}

Key words: gross agricultural output, agricultural production, categories of farms, industry structure, structural shifts and differences, index of physical volume of agricultural production.

Тамбовская область - субъект Российской Федерации, входящий в состав Центрального федерального округа и Центрально-Черноземного экономического района. Хозяйственная специализация области основана на аграрном производстве, так как климат и черноземные почвы глинистого и тяжелосуглинистого механического состава создают благоприятные условия для сельскохозяйственной деятельности.

Сельское хозяйство Тамбовской области производит от 2,1\% до 2,5\% валовой сельскохозяйственной продукции страны, занимая по данному показателю в последние годы среди субъектов Российской Федерации 10-12 место (ранжирование произведено в порядке убывания) [1,с.62]. 
Удельный вес Тамбовской области в аграрном производстве Центрального федерального округа составлял в 2016 г. - 8,3\%, в 2017 г. -8,5\%, в 2018 г. - 8,7\%. Среди областей ЦФО Тамбовская область по данному показателю в 2016-2018 гг. занимала 4 место. Удельный вес Тамбовской области в структуре валовой продукции сельского хозяйства ЦентральноЧерноземного экономического района колеблется от 13,2\% до 16\% [2, с.200].

Продукция сельского хозяйства в стоимостной оценке по фактически действовавшим ценам представляет собой сумму объема продукции растениеводства и животноводства всех категорий сельскохозяйственных производителей.

Как показывают данные таблицы 1, в 2018 г. хозяйствами всех категорий Тамбовской области было произведено продукции сельского хозяйства на сумму 127,3 млрд. руб. Стоимость валовой продукции, произведенной сельскохозяйственными организациями, составила 91,9 млрд. руб., хозяйствами населения - 21,3 млрд. руб., крестьянскими (фермерскими) хозяйствами и индивидуальными предпринимателями - 14,1 млрд. руб.

Таблица 1

\section{Продукция сельского хозяйства по категориям хозяйств в Тамбовской} области за 2008-2018 гг. (в фактически действовавших ценах; млн. руб.)

\begin{tabular}{|c|c|c|c|c|c|c|c|c|}
\hline \multirow{3}{*}{ Годы } & \multicolumn{6}{|c|}{ Категории хозяйств } & \multirow{2}{*}{\multicolumn{2}{|c|}{$\begin{array}{c}\text { Хозяйства всех } \\
\text { категорий }\end{array}$}} \\
\hline & \multicolumn{2}{|c|}{$\begin{array}{c}\text { сельскохозяйственные } \\
\text { организации }\end{array}$} & \multicolumn{2}{|c|}{$\begin{array}{l}\text { хозяйства } \\
\text { населения }\end{array}$} & \multicolumn{2}{|c|}{ КФХ и ИП } & & \\
\hline & всего & $\begin{array}{l}\text { в \% к } \\
\text { итогу }\end{array}$ & всего & $\begin{array}{l}\text { в \% к } \\
\text { итогу }\end{array}$ & всего & $\begin{array}{l}\text { в \% к } \\
\text { итогу }\end{array}$ & всего & $\begin{array}{l}\text { в \% к } \\
\text { итогу }\end{array}$ \\
\hline 2008 & 17659,4 & 49,7 & 13432,1 & 37,8 & 4460,9 & 12,5 & 35552,4 & 100 \\
\hline 2009 & 16345,7 & 43,7 & 16657,2 & 44,6 & 4382,0 & 11,7 & 37384,9 & 100 \\
\hline 2010 & 13325,4 & 39,4 & 17061,8 & 50,5 & 3432,0 & 10,1 & 33819,2 & 100 \\
\hline 2011 & 24209,9 & 50,1 & 18215,9 & 37,7 & 5859,8 & 12,1 & 48285,6 & 100 \\
\hline 2012 & 31222,8 & 56,2 & 17745,0 & 32,0 & 6566,3 & 11,8 & 55534,1 & 100 \\
\hline 2013 & 41308,4 & 62,1 & 17950,5 & 27,0 & 7293,6 & 11,0 & 66552,5 & 100 \\
\hline 2014 & 57849,7 & 66,3 & 20488,7 & 23,5 & 8960,3 & 10,3 & 87298,7 & 100 \\
\hline 2015 & 81348,2 & 68,5 & 23054,9 & 19,4 & 14308,4 & 12,1 & 118711,5 & 100 \\
\hline 2016 & 73916,0 & 67,9 & 21893,8 & 20,1 & 13086,4 & 12,0 & 108896,2 & 100 \\
\hline 2017 & 78346,1 & 70,4 & 22130,7 & 19,9 & 10855,0 & 9,8 & 111331,8 & 100 \\
\hline 2018 & 91868,6 & 72,2 & 21339,7 & 16,8 & 14099,7 & 11,1 & 127308,0 & 100 \\
\hline
\end{tabular}


Удельный вес данных категорий хозяйств равнялся соответственно $72,2 \%, 16,8 \%$ и 11,1\%. Его заметное изменение за последние десять лет свидетельствует о диверсификационных процессах в сельском хозяйстве области, количественно характеризующихся ростом доли сельскохозяйственных организаций, уменьшением доли хозяйств населения и относительно небольшими колебаниями удельного веса фермерского и индивидуального сектора. Сравнение структуры валовой продукции сельского хозяйства в 2018 г. со структурой десятилетней и пятилетней давности, выполненное на основе значений индекса Рябцева, показало существенные структурно-динамические сдвиги аграрного производства в области по сравнению с 2008 г. и весьма низкий уровень различий по сравнению с 2014 г.:

$$
\begin{gathered}
I_{R(2008,2018)}=\sqrt{\sqrt{\frac{\sum_{i=1}^{n}\left(d_{i 1}-d_{i 0}\right)^{2}}{n}\left(d_{i 1}+d_{i 0}\right)^{2}}}=0,227 ; \\
I_{R(2014 ; 2018)}=\sqrt{\sqrt{\sum_{i=1}^{n}\left(d_{i 1}-d_{i 0}\right)^{2}}}=0,062 .
\end{gathered}
$$

Качественная оценка меры существенности изменения структуры производилось на основе шкалы по критерию индекса Рябцева (табл. 2).

Таблица 2

\section{Шкала оценки меры существенности структурных различий по критерию индекса Рябцева}

\begin{tabular}{|c|c|}
\hline Интервал значений индекса Рябцева & Характеристика меры структурных различий \\
\hline $0,000-0,030$ & Тождественность структур \\
\hline $0,031-0,070$ & Весьма низкий уровень различий структур \\
\hline $0,071-0,150$ & Низкий уровень структур \\
\hline $0,151-0,300$ & Существенный уровень различий \\
\hline $0,301-0,500$ & Значительный уровень различий \\
\hline $0,501-0,700$ & Весьма значительный уровень различий \\
\hline $0,701-0,900$ & Противоположный тип структур \\
\hline 0,901 и выше & Полная противоположность структур \\
\hline
\end{tabular}


Проведем структурно-территориальный анализ сельскохозяйственного производства по категориям хозяйств Тамбовской области по сравнению с Российской Федерацией, Центральным федеральным округом и ЦентральноЧерноземный районом за 2016-2018 г. на базе индекса Рябцева.

Таблица 3

Значения индекса Рябцева для оценки структурно-территориальных различий аграрного производства Тамбовской области за 2016-2018 гг.

\begin{tabular}{|c|c|c|c|}
\hline База сравнения & 2016 г. & 2017 г. & 2018 г. \\
\hline РФ & 0,167 & 0,144 & 0,152 \\
\hline ЦФО & 0,071 & 0,025 & 0,032 \\
\hline ЦЧР & 0,063 & 0,020 & 0,026 \\
\hline
\end{tabular}

Данные таблицы 3 показывают существенный уровень различий институциональных структур сельскохозяйственного производства Тамбовской области и РФ, весьма низкий уровень различий структур Тамбовской области и ЦФО, тождественность структур Тамбовской области и ЦЧР.

В разрезе отраслей сельского хозяйства в 2018 г. в Тамбовской области произведено 70,9 млрд. руб. (55,7\% от общего объема) продукции растениеводства и 56,4 млрд. руб. (44,3\%) продукции животноводства (табл. 4).

Это свидетельствует о том, что в сельском хозяйстве области сформировался растениеводческий тип отраслевой структуры производства. В анализируемые годы она значительным образом не изменялась, хотя колебания удельных весов по годам имели место быть.

Существенные изменения претерпела отраслевая структура сельскохозяйственных организаций, где начиная с 2012 г. началось увеличение доли животноводческой продукции. Это связано с началом реализации ряда крупных инвестиционных проектов по свиноводству, развитием мясного птицеводства, строительством молочных комплексов.

Соотношение растениеводческой и животноводческой продукции в разных категориях хозяйств различно. На сельскохозяйственных организациях оно сложилось примерно на среднеотраслевом уровне. В разных субъектах малого хозяйствования отраслевая структура сельскохозяйственного производства отличается. Производственная деятельность крестьянских (фермерских) хозяйств и индивидуальных предпринимателей имеет выраженную растениеводческую направленность. В хозяйствах населения наблюдается преобладание доли животноводческой продукции [3, с. 145]. 
Таблица 4

Объем и отраслевая структура продукции сельского хозяйства

в хозяйствах разных категорий Тамбовской области за 2012 -2018 гг.

(в фактически действовавших ценах; млн. руб.)

\begin{tabular}{|c|c|c|c|c|c|c|c|}
\hline & 2012 г. & 2013 г. & 2014 г. & 2015 г. & 2016 г. & 2017 г & 2018 г. \\
\hline \multicolumn{8}{|c|}{ Хозяйства всех категорий } \\
\hline $\begin{array}{l}\text { Продукция сельского } \\
\text { хозяйства }\end{array}$ & 55534,1 & 66552,5 & 87298,7 & 118711,5 & 108896,2 & 111331,8 & 127308,0 \\
\hline $\begin{array}{l}\text { в том числе } \\
\text { продукция } \\
\text { растениеводства }\end{array}$ & 34609,9 & 41103,8 & 48491,0 & 75869,8 & 67679,3 & 59670,0 & 70944,00 \\
\hline в \% к итогу & 62,3 & 61,8 & 55,5 & 63,9 & 62,2 & 53,6 & 55,7 \\
\hline $\begin{array}{l}\text { продукция } \\
\text { животноводства }\end{array}$ & 20924,2 & 25448,7 & 38807,7 & 42841,7 & 41216,9 & 51661,8 & 56364,0 \\
\hline в \% к итогу & 37,7 & 38,2 & 44,5 & 36,1 & 37,8 & 46,4 & 44,3 \\
\hline \multicolumn{8}{|c|}{ Сельскохозяйственные организации } \\
\hline $\begin{array}{l}\text { Продукция сельского } \\
\text { хозяйства }\end{array}$ & 31222,8 & 41308,4 & 57849,7 & 81348,2 & 73916,0 & 78346,1 & 91868,6 \\
\hline $\begin{array}{l}\text { в том числе } \\
\text { продукция } \\
\text { растениеводства }\end{array}$ & 21633,9 & 27123,8 & 31656,8 & 52952,7 & 46569,3 & 39621,7 & 48027,1 \\
\hline в \% к итогу & 69,3 & 65,7 & 54,7 & 65,1 & 63,0 & 50,5 & 52,3 \\
\hline $\begin{array}{l}\text { продукция } \\
\text { животноводства }\end{array}$ & 9588,9 & 14184,6 & 26192,9 & 28395,5 & 27346,7 & 38724,4 & 43841,5 \\
\hline в \% к итогу & 30,7 & 34,3 & 45,3 & 34,9 & 37,0 & 49,4 & 47,7 \\
\hline \multicolumn{8}{|c|}{ Хозяйства населения } \\
\hline $\begin{array}{l}\text { Продукция сельского } \\
\text { хозяйства }\end{array}$ & 17745,0 & 17950,5 & 20488,7 & 23054,9 & 21893,8 & 22130,7 & 21339,7 \\
\hline $\begin{array}{l}\text { в том числе } \\
\text { продукция } \\
\text { растениеводства }\end{array}$ & 7248,9 & 7706,0 & 9042,3 & 10253,3 & 9805,8 & 10410,1 & 10025,9 \\
\hline в \% к итогу & 40,8 & 42,9 & 44,1 & 44,5 & 44,8 & 47,0 & 47,0 \\
\hline $\begin{array}{l}\text { продукция } \\
\text { животноводства }\end{array}$ & 10496,1 & 10244,5 & 11446,4 & 12801,6 & 12088,0 & 11720,6 & 11313,8 \\
\hline в \% к итогу & 59,2 & 57,1 & 55,9 & 55,5 & 55,2 & 53,0 & 53,0 \\
\hline \multicolumn{8}{|c|}{ Крестьянские хозяйства и индивидуальные предприниматели } \\
\hline $\begin{array}{l}\text { Продукция сельского } \\
\text { хозяйства }\end{array}$ & 6566,3 & 7293,6 & 8960,3 & 14308,4 & 13 086,4 & 10855,0 & 14099,7 \\
\hline $\begin{array}{l}\text { в том числе } \\
\text { продукция } \\
\text { растениеводства }\end{array}$ & 5727,1 & 6274,0 & 7791,9 & 12663,8 & 11304,2 & 9638,2 & 12891,0 \\
\hline в \% к итогу & 87,22 & 86,0 & 87,0 & 88,5 & 86,4 & 88,8 & 91,4 \\
\hline $\begin{array}{l}\text { продукция } \\
\text { животноводства }\end{array}$ & 839,2 & 1019,6 & 1168,4 & 1644,6 & 1782,2 & 1216,8 & 1208,7 \\
\hline в \% к итогу & 12,78 & 14,0 & 13,0 & 11,5 & 13,6 & 11,2 & 8,6 \\
\hline
\end{tabular}


В растениеводстве основными производителями зерна, сахарной свеклы и подсолнечника являются сельскохозяйственные организации, картофеля, овощей, фруктов и ягод - хозяйства населения. В животноводстве сельскохозяйственные организации производят большую часть скота и птицы, хозяйства населения - шерсти, яиц и молока. Фермерские хозяйства и индивидуальные предприниматели вносят заметный вклад в производство зерна, семян подсолнечника, молока [4, с.48].

Проведение анализа динамики стоимости продукции сельского хозяйства в фактически действующих ценах возможно посредством аналитического выравнивания, результатом которого является выявление и характеристика основной тенденции ее изменения путем построения математикостатистических моделей тренда, выраженных в форме уравнений соответствующей аппроксимирующей функции [4, с.63]. Ограничением применения данного метода является возможность адекватного анализа в пределах относительно небольшого периода времени (как правило, пяти лет) ввиду влияния ценового фактора на величину результативного показателя и мобильности изменения природно-климатических и экономических условий его формирования. С учетом этого считаем целесообразным для выявления трендовых показателей сельскохозяйственного производства проводить анализ индексов физического объема продукции сельского хозяйства, которые рассчитываются в целом по продукции сельского хозяйства и в разрезе отдельных категорий сельскохозяйственных производителей. Применение индексов обеспечивает сопоставление объемов производства за длительный период времени в сопоставимой оценке, в результате чего нивелируются различия условий формирования текущих цен в отдельные годы [5, с.138].

В последние десять лет сельскохозяйственное производство Тамбовской области периодически испытывало воздействие негативных природноклиматических и экономических факторов. Среди факторов первой группы наиболее значимыми в анализируемый период были длительная аномальная жара и засуха 2010 г., а также тяжелые погодные условия 2016 г.

Отрицательные воздействия экономического характера проявились в 2009 г. и 2015 г. в первом случае как последствия финансово-экономического кризиса, во втором случае - как ухудшение экономической ситуации в связи с падением цены на нефть, международными антироссийскими санкциями, несоответствием долговых обязательств бюджету страны. 
Сравнивая значения индексов физического объема продукции сельского хозяйства в послекризисные и докризисные периоды в различных категориях сельскохозяйственных товаропроизводителей можно проследить степень их реакции на данные внешние факторы и выявить способность адаптации к ним.

Как видно из данных таблицы 5, в докризисные 2006-2008 годы наиболее высокие темпы роста производства были характерны для фермерского сектора, где наблюдался рост физического объема продукции сельского хозяйства в среднем ежегодно на $22,4 \%$.

Объем сельскохозяйственной продукции в сельскохозяйственных организациях в среднем ежегодно увеличивался на $16,4 \%$, а в хозяйствах населения - снижался на $0,3 \%$.

Таблица 5

Динамика индексов физического объема продукции сельского хозяйства по категориям хозяйств в Тамбовской области за 2006-2018 гг.

\begin{tabular}{|c|c|c|c|c|}
\hline \multirow{2}{*}{ Годы } & \multicolumn{3}{|c|}{$\begin{array}{c}\text { Индексы физического объема продукции сельского хозяйства } \\
\text { (в сопоставимых ценах; в \% к предыдущему году) }\end{array}$} \\
\cline { 2 - 5 } & $\begin{array}{c}\text { хозяйства всех } \\
\text { категорий }\end{array}$ & $\begin{array}{c}|c| \\
\text { в том числе } \\
\text { сельскохозяйственные } \\
\text { организации }\end{array}$ & $\begin{array}{l}\text { хозяйства } \\
\text { населения }\end{array}$ & КФХ и ИП \\
\hline В среднем за 2006-2008 гг. & 110,3 & 116,4 & 99,7 & 122,4 \\
\hline 2009 & 99,9 & 99,0 & 101,5 & 99,9 \\
\hline 2010 & 72,1 & 66,8 & 81,9 & 62,6 \\
\hline 2011 & 164,4 & 201,9 & 125,6 & 183,6 \\
\hline В среднем за 2012-2014 гг. & 112,2 & 123,3 & 94,9 & 105,9 \\
\hline 2015 & 109,7 & 110,6 & 106,5 & 111,7 \\
\hline 2016 & 94,0 & 97,8 & 81,8 & 92,3 \\
\hline В среднем за 2017-2018 гг. & 106,9 & 110,5 & 94,0 & 108,4 \\
\hline
\end{tabular}

Негативное влияние последствий финансово-экономического кризиса 2009 года и сложных природно-экономических условий 2010 года выразилось в низких значениях индекса физического объема продукции сельского хозяйства во всех категориях хозяйств. Следует отметить, что наиболее благоприятная ситуация наблюдалась в хозяйствах населения.

Первый послекризисный 2011 год характеризовался ростом производства у всех товаропроизводителей, но в меньшей степени - у хозяйств населения. В последующие три послекризисные года (2012 - 2014 гг.) наблюдалась 
положительная динамика сельскохозяйственного производства в целом области. При этом в сельскохозяйственных организациях объем продукции в среднем ежегодно увеличивался на 23,3\%, в фермерском секторе - на 5,9\%, а в хозяйствах населения происходило снижение на 5,1\%.

То есть семейно-индивидуальный сектор, показав большую устойчивость в условиях неблагоприятной рыночной конъюнктуры и нетипичных погодных условий, в обычные годы характеризовался регрессивным характером производства [3, с.143].

Другой особенностью явилось превышение на сельскохозяйственных организациях средних темпов роста аграрного производства в послекризисный период (2012-2014 гг.) по сравнению с докризисными показателями (2006-2008 гг.). В субъектах малых формах хозяйствования, напротив, средние темпы роста в послекризисные годы были меньше, чем в докризисный период [5, c. 141].

Последствия экономического кризиса 2015 года явно не сказались на объемах сельскохозяйственного производства области: значения индексов физического объема продукции сельского хозяйства во всех категориях хозяйств были более $100 \%$. Это отчасти можно объяснить значительным объемом инвестиций, направляемых на развитие отрасли региона в течение ряда лет [6, с.234].

В 2016 году ввиду тяжелых погодных условий произошло заметное (на 6\%) снижение объема продукции сельского хозяйства. Причем наиболее существенное его сокращение отмечалось в малых формах хозяйствования: в хозяйствах населения на 18,2\%, в крестьянских (фермерских) хозяйствах - на 7,7\%. Уменьшение объемов производства в сельскохозяйственных организациях составило всего 2,2\%.

В 2017-2018 гг. средний ежегодный прирост производства в сельском хозяйстве области составил 6,9\%. Опережающие темпы прироста были характерны для сельскохозяйственных организаций (10,5\%). Крестьянские (фермерские) хозяйства и индивидуальные предприниматели также продемонстрировали положительную динамику. Хозяйства населения сохранили регрессивный характер аграрного производства. 
Для изучения конкурентных возможностей аграрного сектора Тамбовской области проведем сравнение динамики физического объема продукции сельского хозяйства, в том числе по отдельным сельскохозяйственным производителям и отраслям производства, с данными Российской Федерации и Центрального федерального округа.

Данные таблицы 6 показывают, что в докризисные 2006-2008 гг. средний темп роста аграрного производства в Тамбовской области (110,3\%) превышал среднерегиональный $(108,3 \%)$ и общероссийский $(105,9 \%)$ уровни.

В кризисные 2009 г. и 2010 г. сельское хозяйство Тамбовской области, напротив, показало более низкие темпы роста производства. Однако, в следующем 2011 г. темп прироста аграрного производства существенно превышал и среднерегиональный, и общероссийский уровни.

Такая же ситуация сложилась и в последующие три (2012-2014 гг.) послекризисных года: среднегодовой темп роста сельскохозяйственного производства в Тамбовской области (112,2\%) опережал и общероссийский $(101,6 \%)$, и среднерегиональный $(105,0 \%)$ уровень. Положительную тенденцию изменения объемов продукции в этот период на всех анализируемых территориях продемонстрировали сельскохозяйственные организации и крестьянские (фермерские) хозяйства и индивидуальные предприниматели, у которых среднегодовые темпы ее роста превышали 100\%. Производство сельскохозяйственной продукции в хозяйствах населения носило регрессивный характер, что свидетельствует об общероссийской проблеме развития семейного аграрного сектора.

Аналогичная ситуация сложилась и в послекризисные 2017-2018 гг. В эти годы в среднем ежегодно физический объем продукции сельского хозяйства в Тамбовской области увеличивался на 6,9\%, в ЦФО - на 3,3\%, в РФ - на 1,3\%.

В целом за десять последних лет (2009-2018гг.) средний ежегодный прирост сельскохозяйственной продукции в области, составлял $6,9 \%$, что также выше среднерегионального $(4,6 \%)$ и общероссийского $(2,4 \%)$ значений. 
Таблица 6

Индексы физического объема продукции сельского хозяйства за 2006-2018 гг. в РФ, ЦФО и Тамбовской области по категориям хозяйств (в сопоставимых ценах; в процентах к предыдущему году)

\begin{tabular}{|c|c|c|c|c|c|c|c|c|}
\hline & 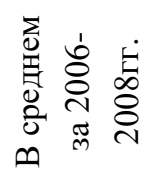 & 嗃 & $\stackrel{\dot{0}}{\stackrel{\circ}{0}}$ & 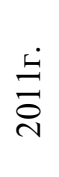 & 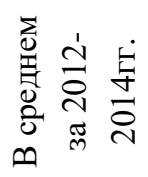 & 点 & 逭 & 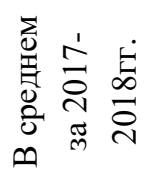 \\
\hline \multicolumn{9}{|c|}{ Сельскохозяйственные организации } \\
\hline $\begin{array}{l}\text { Российская } \\
\text { Федерация }\end{array}$ & $\begin{array}{l}n \\
\infty \\
0\end{array}$ & $\stackrel{\infty}{8}$ & $\stackrel{\forall}{\infty}$ & 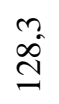 & $\stackrel{\sim}{\tilde{\varepsilon}}$ & 宅 & $\begin{array}{l}0 \\
\stackrel{0}{0}\end{array}$ & 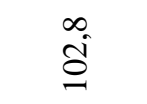 \\
\hline $\begin{array}{l}\text { Центральный } \\
\text { федеральный } \\
\text { округ }\end{array}$ & $\vec{\Xi}$ & $\begin{array}{l}n \\
0\end{array}$ & $\hat{8}$ & $\vec{\infty}$ & $\begin{array}{l}n \\
\infty \\
\infty\end{array}$ & $\overrightarrow{0}$ & $\stackrel{\hat{\sigma}}{\hat{\sigma}}$ & $\tilde{n}$ \\
\hline $\begin{array}{l}\text { Тамбовская } \\
\text { область }\end{array}$ & $\stackrel{+}{\sigma}$ & : & $\underbrace{\infty}_{0}$ & $\vec{a}$ & $\stackrel{m}{\tilde{\Xi}}$ & $\stackrel{\infty}{\Xi}$ & 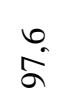 & $\stackrel{n}{\varrho}$ \\
\hline \multicolumn{9}{|c|}{ Хозяйства населения } \\
\hline $\begin{array}{l}\text { Российская } \\
\text { Федерация }\end{array}$ & $\stackrel{a}{0}$ & ầ & $\begin{array}{l}\infty \\
\infty \\
\infty\end{array}$ & $\stackrel{+}{\Xi}$ & $\stackrel{n}{\infty}$ & ڤें & $\stackrel{\circ}{a}$ & $\hat{a}$ \\
\hline $\begin{array}{l}\text { Центральный } \\
\text { федеральный } \\
\text { округ }\end{array}$ & $\overline{8}$ & $\stackrel{?}{0}$ & $\hat{\infty}$ & $\stackrel{\circ}{\stackrel{+}{I}}$ & $\begin{array}{l}0 \\
\infty \\
\infty\end{array}$ & $\overrightarrow{8}$ & i & $\hat{n}$ \\
\hline $\begin{array}{l}\text { Тамбовская } \\
\text { область }\end{array}$ & $\hat{a}$ & $\stackrel{n}{0}$ & $\frac{a}{\infty}$ & $\begin{array}{l}0 \\
\stackrel{a}{\Xi}\end{array}$ & $\stackrel{g}{\text { वे }}$ & $\stackrel{\substack{0 \\
\stackrel{O}{O}}}{\infty}$ & $\stackrel{+}{\infty}$ & $\stackrel{\circ}{+}$ \\
\hline \multicolumn{9}{|c|}{ Крестьянские (фермерские) хозяйства и индивидуальные предприниматели } \\
\hline $\begin{array}{l}\text { Российская } \\
\text { Федерация }\end{array}$ & $\stackrel{0}{\stackrel{0}{0}}$ & $\stackrel{0}{a}$ & $\vec{\infty}$ & $\hat{\text { हे }}$ & $\stackrel{m}{\varrho}$ & $\overrightarrow{0}$ & $\stackrel{n}{=}$ & $\hat{\tilde{s}}$ \\
\hline $\begin{array}{l}\text { Центральный } \\
\text { федеральный } \\
\text { округ }\end{array}$ & $\vec{a}$ & $\stackrel{n}{a}$ & $\stackrel{+}{i}$ & $\stackrel{8}{8}$ & $\stackrel{m}{\infty}$ & $\stackrel{2}{0}$ & $\stackrel{+}{\infty}$ & $\begin{array}{l}\infty \\
\varrho \\
\varrho\end{array}$ \\
\hline $\begin{array}{l}\text { Тамбовская } \\
\text { область }\end{array}$ & 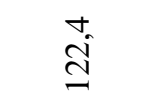 & $\hat{\alpha}$ & $\begin{array}{l}0 \\
i\end{array}$ & $\begin{array}{l}0 \\
\stackrel{\infty}{\infty}\end{array}$ & है & 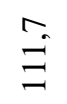 & $\underset{n}{n}$ & $\stackrel{+}{\circ}$ \\
\hline \multicolumn{9}{|c|}{ Хозяйства всех категорий } \\
\hline $\begin{array}{l}\text { Российская } \\
\text { Федерация }\end{array}$ & हैं & $\hat{8}$ & $\frac{a}{\infty}$ & $\stackrel{m}{\text { }}$ & $\begin{array}{l}0 \\
0 \\
0\end{array}$ & $\vec{\delta}$ & $\begin{array}{l}\infty \\
\stackrel{0}{0}\end{array}$ & $\stackrel{m}{0}$ \\
\hline $\begin{array}{l}\text { Центральный } \\
\text { федеральный } \\
\text { округ }\end{array}$ & $\begin{array}{l}m \\
\infty \\
\infty\end{array}$ & $\begin{array}{l}0 \\
\mathbb{0}\end{array}$ & $\begin{array}{l}n \\
\infty\end{array}$ & 离 & है & है & $\hat{\theta}$ & $\stackrel{m}{0}$ \\
\hline $\begin{array}{l}\text { Тамбовская } \\
\text { область }\end{array}$ & $\stackrel{n}{\varrho}$ & $\hat{\sigma}$ & $\vec{i}$ & $\stackrel{+}{+}$ & $\stackrel{\mathfrak{N}}{\Xi}$ & $\hat{a}$ & $\begin{array}{l}0 \\
\dot{\sigma}\end{array}$ & $\stackrel{\theta}{\varrho}$ \\
\hline
\end{tabular}


Индексы физического объема по отраслям производства представлены в таблице 7. Расчеты на их основе показывают, что в отраслевом отношении в последние десять лет среднегодовые темпы роста сельскохозяйственного производства в Тамбовской области и в растениеводстве, и в животноводстве опережали их общероссийские и среднерегиональные значения. Так, за 20092018 гг. средний прирост растениеводческой продукции в РФ равнялся 2,3\%, в ЦФО - 3,5\%, в Тамбовской области - 3,6\%, животноводческой продукции соответственно $2,0 \%, 4,9 \%$ и $11,3 \%$.

Более динамично развивающейся отраслью в области в этот период стало животноводство, где среднегодовой темп прироста объема продукции $(11,3 \%)$ превышал данный показатель в растениеводстве (3,6\%). Это во многом обусловлено приоритетным инвестированием строительства свиноводческих, птицеводческих и молочных комплексов [6]. Инвестирование отрасли способствовало росту производства в ней, что видно из значений индексов физического объема животноводческой продукции, которые в среднем за 20062008 гг. равнялись 98,8\%, а в последующие годы превышали 100\%.

Таблица 7

Динамика производства продукции растениеводства и животноводства в РФ, ЦФО и Тамбовской области за 2006-2018 гг.

\begin{tabular}{|c|c|c|c|c|c|c|c|c|c|c|c|}
\hline & \multicolumn{11}{|c|}{$\begin{array}{c}\text { Индексы физического объёма продукции сельского хозяйства } \\
\text { (в сопоставимых ценах; в процентах к предыдущему году) }\end{array}$} \\
\hline & 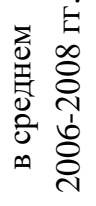 & ڤ્ণ & $\stackrel{\dot{0}}{\stackrel{\circ}{2}}$ & $\stackrel{\dot{\Xi}}{\overrightarrow{2}}$ & 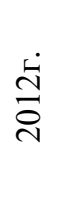 & 官 & $\stackrel{\text { 安 }}{\stackrel{2}{2}}$ & 㝑 & $\stackrel{5}{\stackrel{5}{\circ}}$ & $\underset{⿱ 亠 凶}{\stackrel{4}{5}}$ & $\stackrel{\dot{\infty}}{\stackrel{\infty}{2}}$ \\
\hline \multicolumn{12}{|c|}{ Растениеводство } \\
\hline РФ & $\stackrel{1}{\tilde{c}}$ & \begin{tabular}{l}
0 \\
\multirow{a}{a}{}
\end{tabular} & $\stackrel{\text { शे }}{*}$ & $\overrightarrow{\tilde{\Xi}}$ & $\hat{\infty}$ & $\stackrel{?}{\varrho}$ & $\stackrel{+}{\tilde{o}}$ & $\overrightarrow{\tilde{o}}$ & $\stackrel{\infty}{5}$ & $\stackrel{m}{\stackrel{2}{6}}$ & $\begin{array}{l}n \\
\infty \\
\infty\end{array}$ \\
\hline ЦФО & E. & $\stackrel{m}{\infty}$ & $\begin{array}{l}\infty \\
\dot{b}\end{array}$ & $\begin{array}{l}\infty \\
\stackrel{\infty}{\infty} \\
\stackrel{0}{0}\end{array}$ & 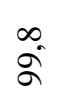 & $\begin{array}{l}0 \\
\stackrel{0}{0}\end{array}$ & $\begin{array}{l}0 \\
\stackrel{0}{0}\end{array}$ & $\vec{\rho}$ & $\begin{array}{l}n \\
\stackrel{n}{0}\end{array}$ & $\stackrel{m}{\sigma}$ & 으 \\
\hline $\begin{array}{l}\text { Тамбовская } \\
\text { область }\end{array}$ & $\hat{\tilde{v}}$ & $\begin{array}{l}\hat{\sigma} \\
\stackrel{\circ}{ }\end{array}$ & $\underset{i n}{\stackrel{+}{n}}$ & 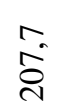 & $\hat{\sigma}$ & $\begin{array}{l}\hat{\Xi} \\
\cong\end{array}$ & हn & $\begin{array}{l}0 \\
\infty \\
=\end{array}$ & $\ddot{8}$ & $\begin{array}{l}\infty \\
\infty \\
\infty \\
0\end{array}$ & $\begin{array}{l}\infty \\
\phi^{-}\end{array}$ \\
\hline
\end{tabular}




\section{ТРАДИЦИИ И ИННОВАЦИИ В СОВРЕМЕННОЙ НАУКЕ И ОБРАЗОВАНИИ: ТЕОРИЯ И ПЕРЕДОВАЯ ПРАКТИКА}

\begin{tabular}{|c|c|c|c|c|c|c|c|c|c|c|c|}
\hline \multicolumn{12}{|c|}{ Животноводство } \\
\hline РФ & $\stackrel{m}{\stackrel{m}{0}}$ & 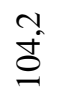 & $\stackrel{2}{8}$ & $\stackrel{+}{i}$ & $\stackrel{+}{\text { ș }}$ & $\stackrel{t}{8}$ & $\begin{array}{l}\infty \\
\tilde{\delta} \\
\tilde{\delta}\end{array}$ & 옹 & $\stackrel{0}{0}$ & $\begin{array}{l}0 \\
\text { î }\end{array}$ & 官 \\
\hline ЦФО & है & $\stackrel{\sim}{\tilde{s}}$ & $\begin{array}{l}\infty \\
i \\
\underline{\delta}\end{array}$ & $\stackrel{\overbrace{}}{\dot{d}}$ & 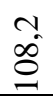 & $\stackrel{8}{0}$ & ह̂ & $\stackrel{0}{0}$ & $\stackrel{+}{8}$ & $\begin{array}{l}0 \\
\text { है } \\
0\end{array}$ & $\stackrel{+}{\tilde{\varepsilon}}$ \\
\hline $\begin{array}{l}\text { Тамбовская } \\
\text { область }\end{array}$ & $\begin{array}{l}\infty \\
\infty \\
\infty\end{array}$ & $\stackrel{0}{\infty}$ & $\begin{array}{l}\infty \\
\dot{8}\end{array}$ & 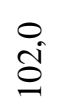 & 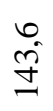 & $\stackrel{n}{\Xi}$ & $\begin{array}{l}n \\
\infty \\
=\end{array}$ & बें & $\stackrel{1}{0}$ & $\stackrel{n}{\beth}$ & ڤn \\
\hline \multicolumn{12}{|c|}{ Сельское хозяйство в целом } \\
\hline РФ & है & $\tilde{8}$ & $\frac{a}{\infty}$ & $\stackrel{m}{\tilde{I}}$ & $\stackrel{+}{+}$ & $\vec{b}$ & tే & ฮิ & $\stackrel{\infty}{+}$ & ฮิ & $\begin{array}{l}\infty \\
\alpha\end{array}$ \\
\hline ЦФО & $\begin{array}{l}m \\
\stackrel{0}{0}\end{array}$ & $\begin{array}{l}\stackrel{0}{0} \\
\stackrel{0}{0}\end{array}$ & $\vec{\infty}_{\hat{\infty}}$ & $\stackrel{r}{\stackrel{+}{2}}$ & $\stackrel{\infty}{\tilde{\varepsilon}}$ & $\begin{array}{l}0 \\
\stackrel{0}{0}\end{array}$ & $\begin{array}{l}n \\
\stackrel{0}{0}\end{array}$ & ‡) & 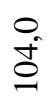 & हn & $\overline{\tilde{\varrho}}$ \\
\hline $\begin{array}{l}\text { Тамбовская } \\
\text { область }\end{array}$ & $\stackrel{n}{0}$ & बे & $\vec{i}$ & 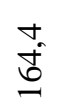 & $\begin{array}{l}0 \\
\hat{0}\end{array}$ & $\begin{array}{l}\text { : } \\
\text { In }\end{array}$ & tे & $\hat{\mathrm{g}}$ & $\begin{array}{l}\stackrel{0}{0} \\
\dot{a}\end{array}$ & $\stackrel{n}{g}$ & $\begin{array}{l}0 \\
8 \\
8\end{array}$ \\
\hline
\end{tabular}

То есть анализ индексов физического объема продукции сельского хозяйства как одного из статистических инструментов изучения динамики сельскохозяйственного производства показал, что сельскохозяйственные товаропроизводители различных категорий демонстрируют разные адаптационные возможности в обстоятельствах нетипичных погодных условий и неблагоприятной рыночной конъюнктуры [7, с. 121].

Более высокие по сравнению с другими товаропроизводителями средние темпы роста аграрного производства сельскохозяйственных организаций в послекрисизные периоды свидетельствуют об их лучшей адаптации к внешним негативным условиям, что во многом связано с большими объемами инвестирования данных аграрных формирований. Реализация крупных инвестиционных проектов по строительству свиноводческих, птицеводческих и молочных комплексов способствовала появлению крупных конкурентов, что вызвало сокращение объема производства продукции в фермерском и семейноиндивидуальном секторах, характеризующихся высокой трудоемкостью и низкой окупаемостью затрат [8, с.206].

Крестьянские (фермерские) хозяйства имеют несколько меньшие средние темпы роста производства по сравнению с сельскохозяйственными организациями, однако ввиду большей мобильности показывают в анализируемый период достаточно стабильные трендовые показатели [9, с.45]. В хозяйствах населения наблюдается снижение сельскохозяйственной 
активности и регрессивный характер динамики производства [10, с.57].

Более высокие средние темпы роста сельскохозяйственного производства в последние десять лет в области, в том числе в растениеводстве и в животноводстве, по сравнению с общероссийскими и среднерегиональными значениями указывают на наличие конкурентных возможностей сельского хозяйства и его основных отраслей [11, с.515].

Таким образом, сельское хозяйство региона характеризуется преобладанием производства в сельскохозяйственных организациях, на которые приходится почти $3 / 4$ валовой продукции отрасли, сохранением растениеводческой направленности при динамичном развитии животноводства.

Динамика сельскохозяйственного производства, выраженная в индексах физического объема продукции сельского хозяйства, отражает происходящую в последние годы диверсификацию аграрной экономики региона в сторону наращивания производственного потенциала крупных агроформирований, располагающих большими возможностями для концентрации производства по сравнению с малыми формами хозяйствования[12, с.244].

\section{Список литературы}

1. Попова В.Б. Анализ структуры валовой продукции сельского хозяйства Тамбовской области//Тенденции развития науки и образования. - 2020. - №643. - С.62-66.

2. Попова В.Б. Статистические аспекты изучения аграрного производства на региональном уровне//Социально-экономическое развитие России и регионов в цифрах статистики: материалы IV международной научнопрактической конференции. 2017. - С. 198-220.

3. Попова В.Б., Фецкович И.В. Анализ сельскохозяйственной деятельности в субъектах малых форм хозяйствования Тамбовской области//Финансовый вестник. - 2016. - №2 (33). - С. 142-151.

4. Попова В.Б., Фецкович И.В. Комплексное исследование аграрного производства с применением статистических методов анализа. Мичуринск: Изд-во Мичуринского ГАУ, 2017. - 112 с.

5. Попова, В.Б., Луганцева А.Г. Адаптационные и конкурентные возможности сельского хозяйства региона//Социально-экономическое развитие России и регионов в цифрах статистики: материалы международной научнопрактической конференции. - 2017. - С. 136-146. 
6. Фецкович И.В., Попова В.Б. Анализ инвестиционной активности региона//Формирование системы устойчивого развития сельского хозяйства на основе концепции стратегического управления (I Шаляпинские чтения). Материалы Всероссийской научно-практической конференции. под. ред.О.Ю. Анциферовой. - 2018. - С.233-239.

7. Попова В.Б. Анализ динамики валовой продукции сельского хозяйства в Тамбовской области//Актуальные проблемы и перспективы развития государственной статистики в современных условиях: сборник материалов IV Международной научно-практической конференции. - 2018.- С. 121-124.

8. Попова В.Б. Статистическая оценка динамики аграрного производства Тамбовской области//Актуальные вопросы совершенствования системы учета, анализа и аудита в организациях: материалы Международной научнопрактической конференции. Ответственный редактор Т.А. Оводкова, 2014. - С. 197-207.

9. Попова В.Б., Фецкович И.В. Статистический анализ сельскохозяйственного производства//Финансы и кредит. - 2015. - №23 (647).C. 40-51.

10. Попова В.Б., Грачева Н.А. Особенности развития индивидуального сектора аграрной экономики // Социально-экономическое развитие России и регионов в цифрах статистики. Материалы V международной научнопрактической конференции. В 2-х томах . - 2019. - С. 52-61.

11. Попова В.Б., Фецкович И.В. Отраслевые особенности сельскохозяйственного производства Тамбовской области//Научнообразовательныеи прикладные аспектыпроизводства и переработки сельскохозяйственной продукции: сб. материалов Междунар. науч.-практ. конф., посвященной 90-летию со дня рождения заслуженного деятеля науки Российской Федерации, Чувашской АССР, Почетного работника высшего профессионального образования Российской Федерации, доктора сельскохозяйственных наук, профессора Александра Ивановича Кузнецова (1930-2015 гг.) (Чебоксары, 16 ноября 2020 г.): в 2 ч. - Ч.2. - Чебоксары, 2020. - C.511-516.

12. Попова В.Б. Особенности динамики сельскохозяйственного производства в различных категориях хозяйств Тамбовской области// Актуальные проблемы и перспективы развития сельского хозяйства и сельских территорий» (III Шаляпинские чтения): Материалы Всероссийской 
(национальной) научно-практической конференции (г. Мичуринск. 26 ноября 2020 г.) / под ред. Н.В. Карамновой. - Мичуринск: Изд-во Мичуринского ГАУ, 2020. - С.241 -245.

() В. Б. Попова, А.С. Лосева, И.В. Фецкович,2021 
УДК 631.115(470.57)

\title{
ПОВЫШЕНИЕ ЭФФЕКТИВНОСТИ РЕСУРСНОГО ПОТЕНЦИАЛА КРЕСТЬЯНСКИХ (ФЕРМЕРСКИХ) ХОЗЯЙСТВ РЕСПУБЛИКИ БАШКОРТОСТАН
}

\author{
Никитина Анжелика Александровна \\ к.э.н., научный сотрудник \\ Башкирский кооперативный институт (филиал) \\ Российского университета кооперации
}

Аннотация: на основе данных региональной статистики и эмпирического исследования была произведена оценка эффективного функционирования региона. Выявлена связь между оптимальным и эффективным использованием всех производственных ресурсов и мощностей, и региональным ростом производства. В этой связи региональные власти должны ориентировать все сферы и отрасли экономики на оптимальное использование имеющегося производственного потенциала региона. Малые формы хозяйствования в этой связи не являются исключением. В данной статье мы предлагаем варианты оптимизации производственных мощностей для крестьянских (фермерских) хозяйств, и индивидуальных предпринимателей работающих в сфере сельскохозяйственного производства.

Ключевые слова: эффективность, оптимизация производства, специализация, региональные особенности, ресурсный потенциал, производственные мощности, экономико-математическое моделирование, малые формы хозяйствования, крестьянские (фермерские) хозяйства, индивидуальные предприниматели, личные подсобные хозяйства.

\section{INCREASING THE EFFICIENCY OF RESOURCE POTENTIAL OF PEASANT (FARM) FARMS IN THE REPUBLIC OF BASHKORTOSTAN}

\section{Nikitina Angelika Alexandrovna}

\begin{abstract}
Based on the data of regional statistics and empirical research, the effective functioning of the region was assessed. The relationship between the


optimal and efficient use of all production resources and capacities and regional production growth is revealed. In this regard, regional authorities should orient all spheres and sectors of the economy towards the optimal use of the existing production potential of the region. Small businesses in this regard are no exception. In this article, we offer options for optimizing production capacity for peasant (farmer) households, and individual entrepreneurs working in the field of agricultural production.

Key words: efficiency, production optimization, specialization, regional features, resource potential, production capacity, economic and mathematical modeling, small forms of management, peasant (farmer) households, individual entrepreneurs, personal subsidiary plots.

Эффективное функционирование региона неразрывно связано с оптимальным и эффективным использованием всех производственных ресурсов и мощностей. В этой связи региональные власти должны ориентировать все сферы и отрасли экономики на оптимальное использование имеющегося производственного потенциала региона. Малые формы хозяйствования в этой связи не являются исключением. Чтобы индивидуальные предприниматели, не выбирали вид производства путем «проб и ошибок» необходима разработка региональных, отраслевых программ оптимального развития производства. В которых, будут рассмотрены вопросы эффективного использования производственных мощностей и оптимальная структура специализации производства.

В данном разделе, мы предлагаем варианты оптимизации производственных мощностей для крестьянских (фермерских) хозяйств, и индивидуальных предпринимателей работающих в сфере сельскохозяйственного производства.

Чтобы добиться эффективного функционирования, должны быть просчитаны все параметры производственной деятельности, которые могут позволить фермерским хозяйствам эффективно функционировать в условиях Республики Башкортостан [6, с.117].

Прежде чем создать крестьянское (фермерское) хозяйство, глава крестьянского (фермерского) хозяйства должен оценить свои трудовые, финансовые возможности и, прежде всего, определить специализацию производства и оптимальный его размер. Достижение многими 270 
функционирующими крестьянскими (фермерскими) хозяйствами оптимальных размеров с учетом специализации производства является задачей на перспективу. Современные условия заставляют глав крестьянских (фермерских) хозяйств, путем «проб и ошибок», добиваться таких размеров, которые позволяют обеспечить получение доходов для осуществления воспроизводства своих хозяйств.

Важным фактором, оказывающим влияние на эффективность фермерских хозяйств, является выбор их специализации и размеров производства, которые во многом определяются территориальным расположением.

Оптимизация отраслей развития фермерских хозяйств осложняется необходимостью учета влияния целого спектра факторов организационноэкономического характера (наличие земельных и трудовых ресурсов, обеспеченность животных кормами, продуктивность животных, урожайность сельскохозяйственных культур, условия транспортировки и хранения продукции, спрос населения на отдельные виды продукции). Учесть все вышеперечисленные факторные признаки в экономико-математической модели невозможно. Поэтому, прежде всего, необходимо отобрать основные из них и оценить их влияние на результативный признак. В сельском хозяйстве строгая линейная зависимость встречается крайне редко. В то же время в целях упрощения расчетов нелинейные связи принимаются за линейные как при математическом моделировании, так и при традиционных методах планирования. Кроме того, многие параметры при планировании носят вероятностный характер и, следовательно, определяются также приблизительно.

Оценивать оптимальность полученного решения целесообразно по одному из перечисленных критериев: максимум валовой продукции; максимум товарной продукции; максимум прибыли (рентабельности); минимум затрат на производство заданного объема продукции. По нашему мнению, наиболее обоснованным, в данном случае, является максимум прибыли.

Постановка задачи - определить оптимальное сочетание отраслей и получение прибыли, обеспечивающих развитие крестьянского (фермерского) хозяйства.

В экономико-математической модели сочетания отраслей используются следующие условные обозначения: 
Константы:

$a_{i j}$ - коэффициенты связи в растениеводстве и животноводстве;

$c_{j}$ - стоимость товарной продукции, получаемой в расчете на единицу измерения ј-го вида деятельности;

$\bar{c}_{j}$ - значение производственных затрат на товарную продукцию, получаемую в расчете на единицу измерения ј-го вида деятельности;

Переменные величины:

$x_{j}$ - размеры ј-го вида деятельности в $\mathrm{h}$ - отрасли производства;

$\bar{x}_{j}$ - количество продукции ј-го вида, реализуемой сверх гарантированного объёма производства;

$\overline{\overline{x_{j}}}$ - значения производственных затрат;

$v_{e j}$ - выход товарной продукции $e$-го вида в расчете на единицу ј-го вида деятельности растениеводства и животноводства;

$Q_{i}$ - объём произведенной продукции і-го вида на корм сельскохозяйственным животным;

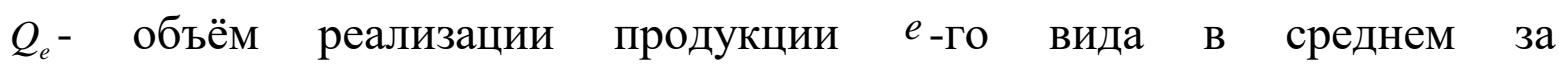
предшествующие годы;

$R_{i}$ - гарантированные объёмы производства продукции ј-го вида;

$\mathrm{P}_{\mathrm{ij}}^{\mathrm{h}}$ - минимально необходимое и максимально возможные объёмы производства.

Математическая запись задачи:

Целевая функция $F_{X}$ - максимум прибыли:

$$
F_{X}=\sum_{j=1}^{n} C_{j}\left(X_{j}^{h}+\bar{X}_{j}^{h}\right)-\sum_{j=1}^{n} \bar{C}_{j}\left(X_{j}^{h}+\bar{X}_{j}^{h}\right) \rightarrow \max
$$

где $\mathcal{C}_{j}$ - стоимость товарной продукции, получаемой в расчете на единицу измерения ј-го вида деятельности;

$\bar{c}_{j}$ - значение производственных затрат на товарную продукцию, получаемую в расчете на единицу измерения ј-го вида деятельности;

$x_{j}$ - искомое значение размеров ј-го вида деятельности в $\mathrm{h}-$-отрасли производства; 
$\bar{x}_{j}$ - количество продукции ј-го вида, реализуемой сверх гарантированного объёма производства.

При постановке задачи приняты следующие ограничения:

1. По использованию сельскохозяйственных угодий

$$
\sum_{j \in J_{1}} a_{i j} x_{j} \leq b_{i} \quad\left(i \in I_{1}\right),
$$

где $a_{i j}$ - коэффициенты связи в растениеводстве и животноводстве;

$b_{i}$ - максимальное количество имеющихся в распоряжении хозяйства земельных ресурсов;

$J_{1}$ - множество, элементы которого являются видами деятельности в растениеводстве;

$I_{1}$ - множество, элементы которого являются номерами ограничений по использованию сельскохозяйственных угодий;

2. По объёму производства сельскохозяйственной продукции

$$
\sum_{j \in J_{1}, J_{2}} v_{i j} x_{j}=R_{i}+\bar{x}_{j} \quad\left(i \in I_{2}\right)
$$

где $v_{i j}$ - выход валовой продукции $i$-го вида в расчете на единицу ј-го вида деятельности растениеводства и животноводства;

$R_{i}$ - гарантированные объёмы производства продукции і-го вида;

$J_{1}$ - множество, элементы которого являются видами деятельности в растениеводстве;

$J_{2}$ - множество, элементы которого являются видами деятельности в животноводстве;

$I_{2}$ - множество, элементы которого являются номерами ограничений по определению оптимальных объёмов производства и использования сельскохозяйственной продукции;

3. По производству и использованию кормов

$$
\sum_{j \in J_{1}} v_{i j} x_{j}+Q_{i} \geq \sum_{j \in J_{2}} a_{i j} x_{j} \quad\left(i \in I_{3}\right),
$$

где $Q_{i}$ - объём произведенной продукции і-го вида на корм сельскохозяйственным животным;

$I_{3}$ - множество, элементы которого являются номерами ограничений по определению оптимальных вариантов рациона кормления различных видов сельскохозяйственных животных; 
4. По объёмам реализации продукции

$$
\sum_{j \in J_{3}} v_{e j} x_{j} \geq Q_{e} \quad\left(e \in I_{4}\right),
$$

где $v_{e j}$ - выход товарной продукции $e$-го вида в расчете на единицу ј-го вида деятельности растениеводства и животноводства;

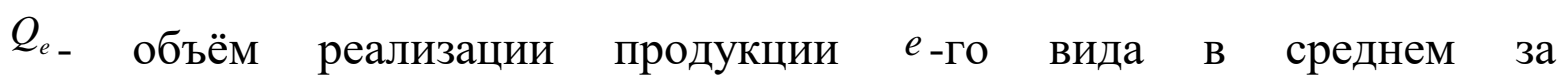
предшествующие годы;

$J_{3}$ - множество, элементы которого являются номерами переменных, определяющих объёмы реализации продукции;

$I_{4}$ - множество, элементы которого являются номерами ограничений по определению объёмов реализации сельскохозяйственной продукции.

При следующих условиях:

1. Допустимые границы изменения размеров производства по всем $\mathrm{h}-$ отраслям производства

$$
\sum_{i=1}^{n} X_{i j} \leq P_{i j}^{h} \geq P_{i j}^{h} \quad\left(i \in I_{2}\right),
$$

где $\mathrm{P}_{\mathrm{ij}}{ }^{\mathrm{h}}$ - минимально необходимые и максимально возможные объёмы производства;

2. Значение производственных затрат по видам продукции

$$
\sum_{j=1}^{n} a_{i j} x_{j}=\overline{\overline{x_{j}}} \quad\left(i \in I_{5}\right)
$$

$=$

где $\bar{x}_{j}$ - искомое значение производственных затрат;

$I_{5}$ - множество, элементы которого являются номерами ограничений по определению оптимальных объёмов производственных затрат;

3. Значение переменных: $x_{j}>0 ; \overline{x_{j}}>0 ; \overline{\overline{x_{j}}}>0$.

Решение экономико-математических задач на основе программного продукта «Simplex» позволило рассчитать оптимальные параметры производства КФХ по природно-климатическим зонам республики [4, с. 220].

Крестьянские (фермерские) хозяйства Предуральской степной зоны имеют площади сельскохозяйственных угодий от 40 до 232 га. На долю пашни приходится около 70-80 \% от сельскохозяйственных угодий. Для выращивания зерновых культур отводится в среднем до 50\% от площади пашни. 


\section{ТРАДИЦИИ И ИННОВАЦИИ В СОВРЕМЕННОЙ НАУКЕ И ОБРАЗОВАНИИ: ТЕОРИЯ И ПЕРЕДОВАЯ ПРАКТИКА}

Хозяйства в данной природно-климатической зоне специализируются на выращивании зерновых и технических культур, овощей открытого и закрытого грунта, кормовых культур, а также на содержании скота молочного и мясного направлений, свиноводстве и овцеводстве.

Зачастую крестьянские (фермерские) хозяйства, имеющие в собственности земельные участки до 70 гектаров, не располагают необходимым количеством тракторов и зерноуборочной техники. В этих условиях основной объём работ осуществляется техникой крупных сельскохозяйственных предприятий на условиях аренды или гужевым транспортом. Данное условие влияет и на специализацию производства, мелкие фермерские хозяйства занимаются производством продукции молочного или мясного скотоводства, а земельные участки в основном используются для производства кормов и выращивания овощных культур, которые можно возделывать без применения мобильной техники. Из данных таблицы 1 видно, что варианты 1-3 позволяют оптимизировать структуру производства крестьянских (фермерских) хозяйств на небольших земельных участках.

Варианты 4-7 предусматривают организацию крестьянских (фермерских) хозяйств на участках до 232 га, с применением мобильной техники, являющейся собственностью фермеров и небольших животноводческих ферм. Вариант 4 предполагает специализацию на производстве продукции растениеводства, в основном зерновых и картофеля. Варианты 5 и 6 направлены на оптимизацию производства мясной продукции на кормах собственного производства. Вариант 7 рассчитан на производство молочной продукции.

Проведенные нами исследования свидетельствуют о том, что фермерские хозяйства, осуществляющие свою производственную деятельность в условиях Предуральской степной зоны, и имеющие земельные участки от 40 до 200 га, могут получать прибыль в среднем от 370 до 1040 тыс.руб. При этом мелкие фермерские хозяйства должны специализироваться на производстве овощных культур и молочном скотоводстве. 
Таблица 1

\section{Варианты организации крестьянских (фермерских) хозяйств}

\section{в Предуральской степной зоне}

\begin{tabular}{|l|c|c|c|c|c|c|c|}
\hline \multicolumn{1}{|c|}{ Показатели } & \multicolumn{7}{c|}{ Bарианты } \\
\cline { 2 - 9 } & 1 & 2 & 3 & 4 & 5 & 6 & 7 \\
\hline Число работников, чел. & 2 & 3 & 4 & 5 & 5 & 5 & 5 \\
\hline Площадь сельскохозяйственных угодий, га & 40 & 60 & 70 & 227 & 232 & 232 & 232 \\
\hline Площадь пашни, га & 25 & 30 & 40 & 200 & 200 & 200 & 200 \\
\hline Поголовье коров, гол. & 4 & 6 & 10 & 5 & 5 & 4 & 17 \\
\hline $\begin{array}{l}\text { Поголовье молодняка крупного рогатого } \\
\text { скота на откорме, гол. }\end{array}$ & 4 & 4 & 4 & 4 & 18 & 26 & 4 \\
\hline Поголовье лошадей, гол. & 1 & 1 & 1 & 2 & 2 & 2 & 2 \\
\hline Поголовье овцематок, гол. & 2 & 2 & 2 & 4 & 2 & 2 & 2 \\
\hline $\begin{array}{l}\text { Себестоимость реализованной продукции, } \\
\text { тыс.руб. }\end{array}$ & 374 & 528 & 644 & 1644 & 1683 & 1548 & 1629 \\
\hline Выручка от реализации, тыс.руб. & 746 & 1061 & 1242 & 2682 & 2705 & 2367 & 2790 \\
\hline Прибыль от реализации продукции, тыс.руб. & 372 & 533 & 599 & 1038 & 1022 & 819 & 1161 \\
\hline $\begin{array}{l}\text { Доходы от реализации молодняка КРС, } \\
\text { тыс.руб. }\end{array}$ & - & 8 & 23 & - & - & - & 50 \\
\hline $\begin{array}{l}\text { Расходы на покупку молодняка КРС, } \\
\text { тыс.руб. }\end{array}$ & - & - & - & - & 50 & 83 & - \\
\hline Доход хозяйства, тыс.руб. & 372 & 540 & 621 & 1038 & 972 & 737 & 1211 \\
\hline $\begin{array}{l}\text { Потребность в капитальных вложениях, } \\
\text { тыс.руб. }\end{array}$ & $\begin{array}{c}180- \\
250\end{array}$ & $\begin{array}{c}260- \\
370\end{array}$ & $\begin{array}{c}230- \\
420\end{array}$ & $\begin{array}{c}390 \\
710\end{array}$ & $\begin{array}{c}360 \text { - } \\
670\end{array}$ & $\begin{array}{c}270- \\
500\end{array}$ & $\begin{array}{c}450 \\
850\end{array}$ \\
\hline
\end{tabular}

Более крупные фермерские хозяйства, имеющие в своей собственности технику, могут специализироваться на производстве зерновых и технических культур, овощей закрытого и открытого грунта, молочном и мясном скотоводстве. Наиболее рентабельным является производство зерновых культур и молочной продукции. Данный вид специализации позволяет получать доход в размере 1211 тыс.руб. Специализируясь на производстве зерновых культур, картофеля и овощей открытого грунта, фермерские хозяйства могут получать доход в размере 1038 тыс.руб.

Высокая себестоимость производства мяса крупного рогатого скота негативно сказывается на размере получаемой прибыли фермерскими хозяйствами. Увеличение поголовья крупного рогатого скота на откорме на 8 голов приводит к сокращению размера получаемого дохода на 235 тыс.руб.

Фермерские хозяйства Южной лесостепной зоны республики имеют от 40 до 450 га сельскохозяйственных угодий. Площадь пашни составляет около 276 
70-80 \% от сельскохозяйственных угодий. Для выращивания зерновых культур отводится в среднем до 50\% от площади пашни [1, с. 152].

Варианты развития фермерских хозяйств по 1 и 2 моделям, приведенные в таблице 2, позволяют оптимизировать структуру производства на небольших земельных участках, преимущественно с применением гужевого транспорта и ручного труда работников хозяйства.

Варианты развития фермерских хозяйств по 3-7 моделям предусматривают организацию крестьянских (фермерских) хозяйств на участках от 227 га до 450 га. Развитие фермерских хозяйств по 3 варианту на общей площади 227 га предполагает специализацию на производстве продукции растениеводства, в основном зерновых, картофеля и сахарной свеклы. Вариант 4 аналогичен специализации варианта 3, но на площади 450 га. Вариант 5 рассчитан на производство молочной продукции. Варианты 6 и 7 направлены на оптимизацию параметров производства мясной продукции.

Хозяйства, имеющие земельные участки от 40 до 70 га, могут заниматься скотоводством молочно-мясного направления, возделыванием зерновых культур, сахарной свеклы, картофеля и овощей открытого грунта. При этом размер получаемого дохода может достигать 602 - 662 тыс.руб.

Варианты 3 и 4 рассчитаны для фермерских хозяйств специализирующихся на производстве зерновых культур. Кроме того, чтобы эффективно использовать имеющиеся трудовые ресурсы и сгладить сезонные колебания в производстве, необходимо развивать отрасли животноводства. При увеличении площади пашни до 400 га хозяйство может получить доход 2043 тыс.руб., что на 756 тыс.руб. больше, чем при площади пашни в 200 га.

Вариант 5 предполагает развитие отрасли скотоводства, молочного направления, а также возделывание зерновых, технических и овощных культур. За счет увеличения площадей сенокосов и пастбищ в данном варианте, возможно, довести поголовье коров до 11 голов, получая при этом 387 ц молока и 9 голов телят на товарные цели. В данном варианте доход может составить 1368 тыс.руб., что на 94 тыс.руб. больше, чем при специализации хозяйств на производстве зерновых культур. 
Таблица 2

\section{Организация крестьянских (фермерских) хозяйств в Южной лесостепной зоне}

\begin{tabular}{|l|c|c|c|c|c|c|c|}
\hline \multirow{2}{*}{ Показатели } & \multicolumn{7}{c|}{ Варианты } \\
\cline { 2 - 9 } & 1 & 2 & 3 & 4 & 5 & 6 & 7 \\
\hline Число работников, чел. & 2 & 3 & 5 & 6 & 6 & 6 & 6 \\
\hline Площадь сельскохозяйственных угодий, га. & 42 & 67 & 227 & 450 & 232 & 232 & 232 \\
\hline Площадь пашни, га. & 30 & 40 & 200 & 400 & 200 & 200 & 200 \\
\hline Поголовье коров, гол. & 2 & 5 & 5 & 5 & 11 & 4 & 3 \\
\hline $\begin{array}{l}\text { Поголовье молодняка крупного рогатого } \\
\text { скота на откорме, гол. }\end{array}$ & 4 & 5 & 5 & 5 & 4 & 18 & 26 \\
\hline Поголовье лошадей, гол. & 1 & 2 & 2 & 2 & 2 & 2 & 2 \\
\hline Поголовье овцематок, гол. & 4 & 4 & 4 & 4 & 2 & 2 & 2 \\
\hline $\begin{array}{l}\text { Себестоимость реализованной продукции, } \\
\text { тыс.руб. }\end{array}$ & 654 & 753 & 1659 & 2849 & 1733 & 1736 & 1718 \\
\hline Выручка от реализации, тыс.руб. & 1256 & 1415 & 2946 & 4892 & 3074 & 3062 & 3020 \\
\hline Прибыль от реализации продукции, тыс.руб. & 602 & 662 & 1287 & 2043 & 1341 & 1326 & 1302 \\
\hline $\begin{array}{l}\text { Доходы от реализации молодняка КРС, } \\
\text { тыс.руб. }\end{array}$ & - & - & - & - & 27 & - & - \\
\hline $\begin{array}{l}\text { Расходы на покупку молодняка КРС, } \\
\text { тыс.руб. }\end{array}$ & - & - & - & - & - & 53 & 87 \\
\hline Доход хозяйства, тыс.руб. & 602 & 662 & 1287 & 2043 & 1368 & 1274 & 1215 \\
\hline $\begin{array}{l}\text { Потребность в капитальных вложениях, } \\
\text { тыс.руб. }\end{array}$ & $\begin{array}{c}180- \\
250\end{array}$ & 250 & 670 & 750 & 670 & 600 & 670 \\
\hline
\end{tabular}

Варианты 6 и 7 предполагают специализация фермерских хозяйств на откорме молодняка крупного рогатого скота и производстве зерновых культур. Но в связи с высокой себестоимостью откорма крупного рогатого скота и необходимостью приобретения телят для постановки на откорм, производство данного вида продукции негативно сказывается на размере получаемой прибыли. Увеличение поголовья скота на откорме с 18 до 26 голов уменьшает сумму получаемого дохода на 59 тыс.руб.

Таким образом, наиболее рентабельными являются многоотрослевые хозяйства, специализирующиеся на производстве зерновых культур, овощей и молочном скотоводстве.

Фермерские хозяйства Северной лесостепной зоны республики имеют большой разброс в размере предоставляемых им земельных участков. Здесь встречаются хозяйства с площадью сельскохозяйственных угодий от 30 до 470 га. Под пашню отводится около 70-80 \% от сельскохозяйственных угодий. Для 
выращивания зерновых культур отводится в среднем до 50\% от площади пашни.

Хозяйства данной природно-климатической зоны специализируются на выращивании зерновых культур, овощей открытого грунта, кормовых культур, а также на содержании скота молочного и мясного направлений, свиноводстве и овцеводстве [4, с. 105].

В данной природно-климатической зоне встречаются мелкие фермерские хозяйства с размерами земельных участков до 20 га. Такие хозяйства являются наименее устойчивыми и мало чем отличаются от личных подсобных хозяйств населения, поскольку обеспечивают продуктами питания в основном лишь членов своей семьи и только сравнительно небольшие излишки продукции реализуют на рынке.

Данные таблицы 3 позволяют оценить эффективность производства в фермерских хозяйствах, имеющих различную специализацию и размеры земельных участков.

Варианты 1-2 предполагают развитие крестьянских (фермерских) хозяйств на небольших земельных участках, преимущественно с применением ручного труда и гужевого транспорта. Варианты 3-10 предусматривают организацию крестьянских (фермерских) хозяйств на участках от 260 га до 470 га, с применением гужевого транспорта и мобильной техники являющейся собственностью фермеров.

Варианты 3 и 4 рассчитаны на организацию фермерского хозяйства на площади 260 га. При этом вариант 3 предусматривает в качестве товарных видов продукции зерно и мясо крупного рогатого скота, а вариант 4 - зерно и молоко. Сумма ожидаемого дохода хозяйства в 4 варианте на 71 тыс.руб. больше, чем в варианте 3 .

Таблица 3

Варианты организации крестьянских (фермерских) хозяйств в Северной лесостепной зоне

\begin{tabular}{|c|c|c|c|c|c|c|c|c|c|c|}
\hline \multirow[t]{2}{*}{ Показатели } & \multicolumn{10}{|c|}{ Варианты } \\
\hline & 1 & 2 & 3 & 4 & 5 & 6 & 7 & 8 & 9 & 10 \\
\hline Число работников, чел. & 2 & 3 & 5 & 5 & 5 & 6 & 6 & 7 & 7 & 7 \\
\hline $\begin{array}{l}\text { Сельскохозяйственных } \\
\text { угодий, га. }\end{array}$ & 30 & 70 & 260 & 260 & 320 & 360 & 360 & 470 & 470 & 470 \\
\hline Площадь пашни, га & 22 & 41 & 190 & 190 & 300 & 300 & 300 & 400 & 400 & 400 \\
\hline
\end{tabular}




\begin{tabular}{|l|c|c|c|c|c|c|c|c|c|c|}
\hline \hline Поголовье коров, гол. & 1 & 4 & 7 & 15 & 2 & 15 & 7 & 7 & 21 & 7 \\
\hline $\begin{array}{l}\text { Поголовье молодняка } \\
\text { КРС на откорме, гол. }\end{array}$ & 1 & 2 & 16 & 2 & 2 & 2 & 18 & 7 & 2 & 29 \\
\hline Поголовье лошадей, гол. & - & 1 & 1 & 2 & 2 & 2 & 2 & 2 & 2 & 2 \\
\hline $\begin{array}{l}\text { Поголовье овцематок, } \\
\text { гол. }\end{array}$ & 2 & 2 & 5 & 5 & 5 & 5 & 5 & 5 & 5 & 5 \\
\hline $\begin{array}{l}\text { Себестоимость } \\
\text { реализованной } \\
\text { продукции, тыс.руб. }\end{array}$ & 381 & 516 & 1710 & 1607 & 1982 & 2051 & 2043 & 2573 & 2660 & 2673 \\
\hline $\begin{array}{l}\text { Выручка от реализации, } \\
\text { тыс.руб. }\end{array}$ & 786 & 992 & 2873 & 2756 & 3327 & 3441 & 3413 & 4208 & 4356 & 4343 \\
\hline $\begin{array}{l}\text { Прибыль от реализации } \\
\text { продукции, тыс.руб. }\end{array}$ & 405 & 476 & 1163 & 1149 & 1346 & 1391 & 1370 & 1635 & 1697 & 1670 \\
\hline $\begin{array}{l}\text { Доходы от реализации } \\
\text { молодняка КРС, тыс.руб. }\end{array}$ & - & 8 & - & 50 & - & 50 & - & - & 72 & - \\
\hline $\begin{array}{l}\text { Расходы на покупку } \\
\text { молодняка КРС, тыс.руб. }\end{array}$ & - & - & 35 & - & - & - & 42 & - & - & 83 \\
\hline $\begin{array}{l}\text { Доход хозяйства, } \\
\text { тыс.руб. }\end{array}$ & 405 & 483 & 1128 & 1199 & 1346 & 1440 & 1328 & 1635 & 1769 & 1587 \\
\hline $\begin{array}{l}\text { Потребность в } \\
\text { капитальных вложениях, } \\
\text { тыс.руб. }\end{array}$ & $150-$ \\
\hline
\end{tabular}

Для организации производства по вариантам 5, 6 и 7 необходимо от 320 до 360 га сельскохозяйственных угодий. На данной площади возможно организовать многоотраслевого производства, где в качестве товарных видов продукции будут выступать зерно, молоко и мясо крупного рогатого скота. Проведенные исследования свидетельствуют о том, что наиболее рентабельными являются хозяйства, специализирующиеся на производстве молока и зерна (вариант 6), на втором месте хозяйства, возделывающие в основном зерновые культуры (вариант 5) и хозяйства, специализирующиеся на мясном скотоводстве с развитым производством зерновых культур (вариант 7). Доходы перечисленных фермерских хозяйств составляют соответственно 1346, 1440 и 1328 тыс.руб.

Аналогично осуществлены расчеты по вариантам 8, 9 и 10, но на площади земельных участков 470 га. Данные варианты организации фермерских хозяйств подтверждают, что наиболее эффективно функционируют хозяйства, производящие молоко и зерно (вариант 9), далее следуют хозяйства, производящие зерно в качестве основного вида товарной продукции (вариант 8) 
и хозяйства, занимающиеся производством зерна и откормом крупного рогатого скота (вариант 10). Величина получаемых доходов в хозяйствах этих вариантов составляет соответственно 1635, 1769 и 1587 тыс.руб.

Фермерские хозяйства Северо-восточной лесостепной зоны республики располагают площадью сельскохозяйственных угодий от 20 до 250 га. Под пашню отводится около 70-80\% от сельскохозяйственных угодий [1, с. 110].

Хозяйства в данной природно-климатической зоне специализируются на выращивании зерновых культур, картофеля, кормовых культур, а также на содержании скота молочного и мясного направлений, свиноводстве и овцеводстве.

Моделирование оптимального сочетания отраслей в условиях Северовосточной лесостепной зоны позволяет дать оценку её производственному потенциалу. В этих условиях основополагающую роль играют природноклиматические условия, которые негативно влияют на урожайность сельскохозяйственных культур и не позволяют возделывать овощные и технические культуры. В связи с этим, сельскохозяйственные товаропроизводители в данной зоне специализируются на развитии отрасли скотоводства.

В таблице 4 представлены основные варианты организации крестьянских (фермерских) хозяйств в условиях Северо-восточной лесостепной зоны.

Данные таблицы 4 свидетельствуют о том, что мелкотоварное производство, размещенное на небольших земельных участках, в данной зоне является малоэффективным, поскольку оно не имеет средств для расширения производства, приобретения техники и строительства ферм.

Таблица 4

Варианты организации крестьянских (фермерских) хозяйств

в Северо-восточной лесостепной зоне

\begin{tabular}{|l|c|c|c|c|c|c|c|c|c|c|}
\hline \multicolumn{1}{|c|}{ Показатели } & \multicolumn{10}{|c|}{ Варианты } \\
\cline { 2 - 13 } & 1 & 2 & 3 & 4 & 5 & 6 & 7 & 8 & 9 & 10 \\
\hline Число работников, чел. & 2 & 2 & 3 & 4 & 5 & 5 & 5 & 6 & 6 & 6 \\
\hline $\begin{array}{l}\text { Сельскохозяйственные } \\
\text { угодия, га. }\end{array}$ & 23 & 23 & 40 & 160 & 190 & 190 & 190 & 250 & 250 & 250 \\
\hline Площадь пашни, га. & 15 & 15 & 28 & 120 & 145 & 145 & 145 & 160 & 160 & 160 \\
\hline Поголовье коров, гол. & 2 & 1 & 2 & 6 & 6 & 15 & 6 & 17 & 24 & 9 \\
\hline Поголовье молодняка & 1 & 2 & 2 & 7 & 10 & 2 & 25 & 22 & 2 & 44 \\
\hline
\end{tabular}




\begin{tabular}{|l|c|c|c|c|c|c|c|c|c|c|}
\hline \hline КРС на откорме, гол. & & & & & & & & & & \\
\hline Поголовье лошадей, гол. & - & - & 1 & 1 & 1 & 1 & 1 & 2 & 2 & 2 \\
\hline Поголовье овцематок, гол & 2 & 2 & 2 & 2 & 2 & 2 & 2 & 2 & 2 & 2 \\
\hline $\begin{array}{l}\text { Себестоимость } \\
\text { реализованной } \\
\text { продукции, тыс.руб. }\end{array}$ & 141 & 276 & 290 & 704 & 807 & 852 & 884 & 1074 & 1043 & 1107 \\
\hline $\begin{array}{l}\text { Выручка от реализации, } \\
\text { тыс.руб. }\end{array}$ & 201 & 389 & 408 & 1035 & 1190 & 1271 & 1215 & 1559 & 1551 & 1566 \\
\hline $\begin{array}{l}\text { Прибыль от реализации } \\
\text { продукции, тыс.руб. }\end{array}$ & 60 & 113 & 119 & 332 & 383 & 419 & 332 & 485 & 509 & 459 \\
\hline $\begin{array}{l}\text { Доходы от реализации } \\
\text { молодняка КРС,тыс.руб. }\end{array}$ & - & - & - & - & - & 50 & - & - & 83 & - \\
\hline $\begin{array}{l}\text { Расходы на покупку } \\
\text { молодняка КРС, тыс.руб. }\end{array}$ & - & - & - & - & 15 & - & 72 & 20 & - & 132 \\
\hline Доход хозяйства,тыс.руб. & 60 & 113 & 119 & 332 & 368 & 468 & 260 & 465 & 591 & 327 \\
\hline $\begin{array}{l}\text { Потребность в } \\
\text { капитальных вложениях, } \\
\text { тыс.руб. }\end{array}$ & - & 75 & 75 & $\begin{array}{c}180- \\
220\end{array}$ & $220-$ & $220-$ & $220-$ & $220-$ & $220-$ & $220-$ \\
\hline
\end{tabular}

Вариант 4 разработан для организации фермерского хозяйства на площади до 160 га с полным оборотом стада крупного рогатого скота.

Варианты 6 и 9 предполагают производство продукции молочного направления в скотоводстве на площади 190-250 га.

Варианты 7 и 10 предполагают развитие мясного скотоводства на площадях 190-250 га.

В условиях данной зоны наиболее рентабельным является производство продукции молочного скотоводства.

Фермерские хозяйства Зауральской степной зоны республики располагают площадью сельскохозяйственных угодий в среднем от 30 до 120 га. Удельный вес пашни составляет 50-70 \% сельскохозяйственных угодий. Для выращивания зерновых культур отводится в среднем до $80 \%$ от площади пашни.

Хозяйства в данной природно-климатической зоне специализируются на выращивании зерновых культур, картофеля, кормовых культур, а также на содержании скота молочного и мясного направлений, овцеводстве.

Природно-климатические условия Зауральской степной зоны не позволяют возделывать на товарные цели продукцию растениеводства. Данная 
отрасль развивается лишь для обеспечения членов семьи продуктами питания и в качестве кормовой базы для скота [3, с. 202].

Фермерские хозяйства в условиях зоны специализируются на молочном и мясном скотоводстве, о чем свидетельствуют варианты организации фермерских хозяйств, представленные в таблице 5 .

Варианты 1-2 моделей позволяют организовать производство на небольших земельных участках, преимущественно с применением ручного труда и гужевого транспорта. Они предполагают специализацию на производстве продукции скотоводства с полным оборотом крупного рогатого скота.

Таблица 5

\section{Варианты организации крестьянских (фермерских) хозяйств}

в Зауральской степной зоне

\begin{tabular}{|l|c|c|c|c|c|c|}
\hline \multicolumn{1}{|c|}{ Показатели } & \multicolumn{5}{c|}{ Варианты } \\
\cline { 2 - 7 } & 1 & 2 & 3 & 4 & 5 & 6 \\
\hline Число работников, чел. & 2 & 2 & 3 & 3 & 4 & 4 \\
\hline Площадь сельскохозяйственных угодий, га. & 36 & 49 & 90 & 90 & 120 & 120 \\
\hline Площадь пашни, га. & 25 & 35 & 68 & 68 & 87 & 87 \\
\hline Поголовье коров, гол. & 2 & 4 & 7 & 4 & 12 & 6 \\
\hline $\begin{array}{l}\text { Поголовье молодняка крупного рогатого скота } \\
\text { на откорме, гол. }\end{array}$ & 4 & 4 & 2 & 9 & 2 & 19 \\
\hline Поголовье лошадей, гол. & & & & & & \\
\hline Поголовье овцематок, гол. & 1 & 1 & 1 & 1 & 2 & 2 \\
\hline $\begin{array}{l}\text { Себестоимость реализованной продукции, } \\
\text { тыс.руб. }\end{array}$ & 2 & 2 & 2 & 2 & 2 & 2 \\
\hline Выручка от реализации, тыс.руб. & 2174 & 344 & 336 & 464 & 482 \\
\hline Прибыль от реализации продукции, тыс.руб. & 77 & 102 & 156 & 143 & 230 & 210 \\
\hline Доходы от реализации молодняка КРС, тыс.руб. & - & - & 20 & - & 38 & - \\
\hline Расходы на покупку молодняка КРС, тыс.руб. & 8 & - & - & 20 & - & 50 \\
\hline Доход хозяйства, тыс.руб. & 69 & 102 & 176 & 123 & 267 & 161 \\
\hline $\begin{array}{l}\text { Потребность в капитальных вложениях, } \\
\text { тыс.руб. }\end{array}$ & - & - & $70-$ & $70-$ & $100-$ & $100-$ \\
\end{tabular}

Варианты 3 и 5 рассчитаны на развитие молочного скотоводства на площадях 90-120 га. В данных вариантах предусматривается увеличение поголовья коров за счет роста размера земельных участков. Величина получаемого дохода при этом возрастает на 91 тыс.руб. 
Варианты 4 и 6 предполагают развитие мясного скотоводства. На земельных участка 90-120 га производится откорм 9-19 гол крупного рогатого скота. При данном уровне специализации в хозяйствах возможно получение дохода в размере 123-161 тыс.руб., увеличение дохода составляет 38 тыс.руб.

Проведенные исследования свидетельствуют о том, что в условиях Зауральской степной зоны оптимальными вариантами специализации, приносящими максимальный доход фермерам, является молочное скотоводство.

Фермерские хозяйства Горно-лесной зоны республики располагают площадью сельскохозяйственных угодий от 30 до 80 га. Под пашню отводится около 50-70 \% от сельскохозяйственных угодий. Для выращивания зерновых культур 30-70\% от площади пашни [1, с.120].

Хозяйства в данной природно-климатической зоне специализируются на выращивании зерновых культур, картофеля, кормовых культур, а также на содержании скота молочного и мясного направлений, овцеводстве и коневодстве.

В условиях Горно-лесной зоны функционируют небольшие по размерам фермерские хозяйства с размером земельных участков до 80 га. Это связано с рельефными условиями зоны, не позволяющими на больших территориях возделывать зерновые культуры. Данная зона традиционно является скотоводческой.

Развитие крупных фермерских хозяйств в условиях данной зоны является неэффективным, из-за рельефа местности и природно-климатических условий. Максимальный доход хозяйства, получаемый с площади в 80 га, едва достигает 167 тыс. руб.

Таблица 6

Варианты организации крестьянских (фермерских) хозяйств в Горно-лесной зоне

\begin{tabular}{|l|c|c|c|c|c|c|c|}
\hline \multicolumn{1}{|c|}{ Показатели } & \multicolumn{7}{c|}{ Варианты } \\
\cline { 2 - 10 } & 1 & 2 & 3 & 4 & 5 & 6 & 7 \\
\hline Число работников, чел. & 2 & 3 & 3 & 3 & 4 & 4 & 4 \\
\hline Площадь сельскохозяйственных угодий, га & 34 & 49 & 49 & 49 & 80 & 80 & 80 \\
\hline Площадь пашни, га & 23 & 33 & 33 & 33 & 54 & 54 & 54 \\
\hline Поголовье коров, гол & 2 & 3 & 4 & 2 & 5 & 7 & 4 \\
\hline $\begin{array}{l}\text { Поголовье молодняка крупного рогатого } \\
\text { скота на откорме, гол }\end{array}$ & 2 & & & & & & \\
\hline
\end{tabular}




\begin{tabular}{|l|c|c|c|c|c|c|c|}
\hline \hline Поголовье лошадей, гол & 1 & 1 & 1 & 1 & 1 & 2 & 2 \\
\hline Поголовье овцематок, гол & 2 & 2 & 2 & 2 & 2 & 2 & 2 \\
\hline $\begin{array}{l}\text { Себестоимость реализованной продукции, } \\
\text { тыс.руб. }\end{array}$ & 135 & 195 & 191 & 194 & 323 & 305 & 309 \\
\hline Выручка от реализации, тыс.руб. & 195 & 284 & 279 & 278 & 474 & 452 & 447 \\
\hline $\begin{array}{l}\text { Прибыль от реализации продукции, } \\
\text { тыс.руб. }\end{array}$ & 60 & 89 & 89 & 84 & 152 & 147 & 138 \\
\hline $\begin{array}{l}\text { Доходы от реализации молодняка КРС, } \\
\text { тыс.руб. }\end{array}$ & - & 5 & 8 & - & 12 & 20 & - \\
\hline $\begin{array}{l}\text { Расходы на покупку молодняка КРС, } \\
\text { тыс.руб. }\end{array}$ & - & - & - & 23 & - & - & 30 \\
\hline Доход хозяйства, тыс.руб. & 60 & 93 & 96 & 62 & 164 & 167 & 108 \\
\hline $\begin{array}{l}\text { Потребность в капитальных вложениях, } \\
\text { тыс.руб. }\end{array}$ & - & - & - & - & 75 & 75 & 75 \\
\hline
\end{tabular}

К примеру, в условиях Предуральской степной зоны с аналогичного по размерам земельного участка возможно получить доход хозяйства на сумму 540 - 621 тыс.руб. Это свидетельствует о том, что развитие отраслей животноводства и растениеводства в условиях данной зоны является неэффективным и осуществляется лишь в целях обеспечения членов семьи продуктами питания, являясь натуральной формой хозяйствования [4, с. 120].

Таким образом, экономико-математическое моделирование дает возможность определить основные параметры развития производства для текущего и перспективного планирования, может использоваться для анализа сложившейся структуры производства, позволяющего выявить более целесообразные пути использования ресурсного потенциала региона и возможности увеличения объёмов производства продукции в регионе.

\section{Список литературы}

1. Анализ эффективности функционирования крестьянских (фермерских) хозяйств с учетом региональных особенностей Республики Башкортостан: монография / Никитина А.А. / Монография. - г. Оренбург. Издательство: ООО «Апробация» (Махачкала). 2017. 188 с. ISBN:978-5-9909629-0-3

2. Никитина А.А. Классификация фермерских хозяйств с учетом зарубежного опыта ведения фермерства // Региональная экономика: теория и практика. Научно-практический и аналитический журнал. 28(259)-2012 февраль. С. 60-63. 
3. Направления развития крестьянских (фермерских) хозяйств в Зауралье / Никитина А.А. / В сборнике: Агроэкономические и социальноэкономические проблемы и перспективы развития АПК Зауралья. Материалы региональной научно-практической конференции. Министерство образования и науки РФ, Зауральский филиал ФГОУ ВПО «Башкирский государственный аграрный университет». - Издательство: БГАУ (Уфа). 2009. С.200-203.

4. Никитина А.А. Развитие крестьянских (фермерских) хозяйств (на примере Республики Башкортостан): диссертация на соискание ученой степени кандидата экономических наук / Башкирский государственный аграрный университет. Уфа. 2006. 233 с.

5. Оптимизация крестьянских (фермерских) хозяйств на основу арендных отношений / Хабиров Г.А., Никитина А.А. // Экономика сельскохозяйственных и перерабатывающих предприятий. 2006. №6. С. 28-31. ISSN: 0235-2494

6. Перспективы развития сельского хозяйства Республики Башкортостан / Давлетбаева Л.Р., Никитина А.А. // Экономика и предпринимательство. 2013. №2(31). С.117-120. ISSN: 1999-2300

7. Региональные особенности и эффективность деятельности хозяйств сельского населения Республики Башкортостан / Давлетбаева Л.Р. // Современные проблемы науки и образования. 2012. № 6. С. 403.

(C) А.А. Никитина 


\title{
Коллектив авторов
}

Барчо О.Ф., Бура Л.В., Бурдинская А.Н., Виноградов В.Л., Газиева Л.Р., Дулов М.И., Жигайлова Л.В., Заварзина Г.А., Залевская Я.Г., Зарецкий А.М., Идигова Л.М., Каспаров И.В., Лосева А.С., Неделько А.А., Никитина А.А., Пегова Х.Р., Попель А.А., Попова В.Б., Прокопьев В.Н., Пшениснов Н.В., Свистун Г.М., Суровцева Е.В., Талышева И.А., Тихонова И.В., Фецкович И.В., Хаджиева М.М., Чуешкова А.А., Чурюканова Е.О.

НАУЧНОЕ ИЗДАНИЕ

\section{ТРАДИЦИИ И ИННОВАЦИИ В СОВРЕМЕННОЙ НАУКЕ И ОБРАЗОВАНИИ: ТЕОРИЯ И ПЕРЕДОВАЯ ПРАКТИКА}

\author{
Монография \\ Подписано в печать 02.03.2021. \\ Формат 60x84 1/16. Усл. печ. л. 16,62. \\ Тираж 500 экз. \\ МЦНП «Новая наука» \\ 185002, г. Петрозаводск \\ ул. С. Ковалевской д.16Б помещ. 35 \\ office@sciencen.org \\ www.sciencen.org
}

